\author{
UNIVERSIDADE DE SÃO PAULO \\ FACULDADE DE FILOSOFIA, LETRAS E CIÊNCIAS HUMANAS \\ DEPARTAMENTO DE TEORIA LITERÁRIA E LITERATURA COMPARADA
}

\author{
Fabio Weintraub
}

\title{
O tiro, o freio, o mendigo e o outdoor: representações do espaço urbano na poesia brasileira pós-1990
}

"Versão corrigida"

São Paulo

2013 
UNIVERSIDADE DE SÃO PAULO

FACULDADE DE FILOSOFIA, LETRAS E CIÊNCIAS HUMANAS

DEPARTAMENTO DE TEORIA LITERÁRIA E LITERATURA COMPARADA

\author{
Fabio Weintraub
}

\title{
O tiro, o freio, o mendigo e o outdoor: \\ representações do espaço urbano na \\ poesia brasileira pós-1990
}

"Versão corrigida"

Tese apresentada ao Programa de

Pós-graduação em Teoria Literária

e Literatura Comparada da

Faculdade de Filosofia, Letras e

Ciências Humanas da Universidade

de São Paulo para obtenção do

título de Doutor em Letras.

Orientadora: Prof. ${ }^{\text {a }}$ D. ${ }^{\text {ra }}$ Iumna Maria Simon

De acordo:

Assinatura da orientadora:

São Paulo 
Autorizo a reprodução e divulgação total ou parcial deste trabalho, por qualquer meio convencional ou eletrônico, para fins de estudo e pesquisa, desde que citada a fonte.

Catalogação na Publicação

Serviço de Biblioteca e Documentação

Faculdade de Filosofia, Letras e Ciências Humanas da

Universidade de São Paulo

\begin{tabular}{|c|c|}
\hline $\mathrm{W} 423 \mathrm{t}$ & $\begin{array}{l}\text { Weintraub, Fabio } \\
\text { O tiro, o freio, o mendigo e o outdoor: } \\
\text { representações do espaço urbano na poesia brasileira } \\
\text { pós- } 1990 \text { / Fabio Weintraub ; orientador Iumna Simon. - } \\
\text { São Paulo, } 2013 \text {. } \\
203 \mathrm{f} \text {. }\end{array}$ \\
\hline & $\begin{array}{l}\text { Tese (Doutorado) - Faculdade de Filosofia, Letras } \\
\text { e Ciências Humanas da Universidade de São Paulo. } \\
\text { Departamento de Teoria Literária e Literatura } \\
\text { Comparada. Área de concentração: Teoria Literária e } \\
\text { Literatura Comparada. }\end{array}$ \\
\hline & $\begin{array}{l}\text { 1. Literatura brasileira. 2. Poesia contemporânea. } \\
\text { 3. Urbanismo. I. Simon, Iumna, orient. II. Título }\end{array}$ \\
\hline
\end{tabular}


WEINTRAUB, F. O tiro, o freio, o mendigo e o outdoor: representações do espaço urbano na poesia brasileira pós-1990. Tese apresentada à Faculdade de Filosofia, Letras e Ciências Humanas da Universidade de São Paulo para obtenção do título de Doutor em Teoria Literária e Literatura Comparada.

\section{Banca Examinadora}

Prof. Dr.

Instituição:

Assinatura:

Prof. Dr.

Instituição:

Assinatura:

Prof. Dr.

Instituição:

Assinatura:

Prof. Dr.

Instituição:

Assinatura:

Prof. Dr.

Instituição:

Assinatura: 
Em memória de meu pai, Samuel Weintraub, que me ensinou a andar pela cidade, e para Antonio, companheiro de toda a vida, que acha graça no tanto que eu me perco. 


\section{AGRADECIMENTOS}

A Ecléa Bosi, que me fez ver quanto devem nossas lembranças às pedras da cidade.

A Isaura Botelho, por ter me estimulado a retomar os estudos em um momento particularmente difícil de minha vida.

Aos companheiros da editora, sobretudo aos da equipe de literatura (Cláudia Ribeiro Mesquita, Graziela R. S. Costa Pinto, Belisa Monteiro, Laura Daviña e Denis Araki, colegas de agora, e também Dolores Prades, Leonardo Carvalho e Vivian Pennafiel, colegas de antes), que me ajudaram a encontrar tempo para a pesquisa em meio à correria dos fechamentos.

A Alberto Martins, Alexandre Nodari, Álvaro Faleiros, Ana Paula Pacheco, Andrea Saad Hossne, Betina Bischof, Chantal Castelli, Eduardo Sterzi, Iuri Pereira, Ivone Daré Rabello, Jaime Ginzburg, José Eduardo de Assis Lefèvre, José Moura Gonçalves Filho, Murilo Marcondes Moura, Paulo Ferraz, Priscila Figueiredo, Renan Nuernberger, Ricardo Rizzo, Rita Jover-Faleiros, Ruy Proença, Simone Rufinoni, Tarso de Melo, Tércio Loureiro Redondo, Tereza Costa, Veronica Stigger, Viviana Bosi, amigos, colegas, professores e poetas, pelo estímulo, por leituras e sugestões.

A Ronald Polito, pelo apoio (leitura, conversas e revisões) nos momentos finais, e a Marcia Menin, pela revisão derradeira.

A Paulo Arantes, pelo convite para falar da pesquisa no Seminário das Quartas.

Aos membros das bancas de qualificação, Fabio de Souza Andrade, Pedro Arantes e Vagner Camilo, pelas arguições valiosas, contribuição essencial à pesquisa.

A Iumna Maria Simon, minha orientadora, pelo exemplo crítico, pela interlocução atenta, rigorosa e constante, pela paciência com meus destemperos e pela liberdade que sempre me concedeu para seguir por onde eu quisesse.

A minha mãe, Ana Rebeka Weintraub, sempre repetindo "vai dar tudo certo".

E, mais uma vez, a Antonio, cujo amor me abriga, transporta e protege em qualquer cidade. 


\section{RESUMO}

O presente trabalho constitui uma investigação sobre as estratégias de representação da cidade na poesia brasileira contemporânea, segundo quatro eixos temáticos: representações sobre violência, circulação, moradia e temporalidade no espaço urbano. Analisam-se poemas de oito autores - Alberto Martins, Duda Machado, Eduardo Sterzi, Pádua Fernandes, Paulo Ferraz, Régis Bonvicino, Ronald Polito e Tarso de Melo - em cuja obra os temas de cada eixo ocupam lugar de relevo. Do ponto de vista temporal, a maioria dos poemas pertence a livros escritos na última década e meia e representa uma guinada realista dentro da tendência de negação das referências concretas ao país e ao momento histórico, dominante nos anos 1980 e em boa parte da década seguinte. A escolha do marco pós-1990 levou também em conta circunstâncias de agravamento da crise habitacional, incremento da violência, colapso dos transportes e museificação urbana, cujo impacto sobre os poetas é avaliado mediante comparações não sistemáticas com momentos anteriores de nossa poesia (e, mais pontualmente, da canção brasileira) em que temas semelhantes recebem tratamento diverso. Tais comparações ensejam, ainda, uma reflexão sobre o vínculo da poesia contemporânea com seus antecedentes próximos (o legado modernista, o experimentalismo concretista e as contribuições da poesia marginal). Para a descrição das novas configurações de cidade e para a discussão do diálogo do contemporâneo com a poesia do século XX, aproveitam-se contribuições da arquitetura, do urbanismo, da antropologia e da sociologia urbanas, entre outras disciplinas.

Palavras-chave: poesia brasileira contemporânea, pós-urbano, realismo, transporte, habitação, segurança. 


\section{ABSTRACT}

The shot, the brake, the beggar and the outdoor: Representations of urban space in the Brazilian poetry of the post-90s

The present work is a research into the strategies of representation of the city in contemporary Brazilian poetry, according to four themes: representations of violence, circulation, housing and temporality in the urban space. It analyzes eight authors - Alberto Martins, Duda Machado, Eduardo Sterzi, Pádua Fernandes, Paulo Ferraz, Régis Bonvicino, Ronald Polito and Tarso de Melo - in whose work these themes occupy a prominent place. From the temporal point of view, most of the poems belong to books written in the last fifteen years, and they represent a realistic shift within the trend of denial of concrete references to the country and to the historical moment, a trend that was dominant in the 1980s and much of the following decade. The choice of post-nineties also took into account the historical circumstances of aggravation of the housing crisis, the increased violence, the breakdown of transport and urban museification, whose impact on the poets is evaluated by non systematic comparisons with previous periods of our poetry (and, more occasionally, with the Brazilian song) in which similar themes are treated differently. Such comparisons also engender a reflection on the relation of contemporary poetry with its close background (the modernist legacy, the experimentalism of Concrete Poetry and contributions of Marginal Poetry). In order to describe the new settings of the city and to discuss the dialogue between the contemporaneous and the poetry of the twentieth century, this work benefited from contributions of architecture, urban planning, urban anthropology and sociology, among other disciplines.

Keywords: Brazilian Contemporary Poetry, Post-Urban, Realism, Transport, Housing, Security. 


\section{Sumário}

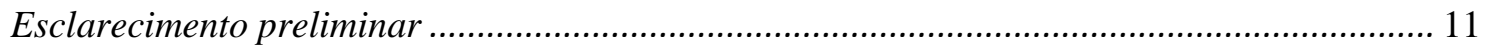

Apresentação: desafios representacionais da cidade contemporânea ......................................... 19

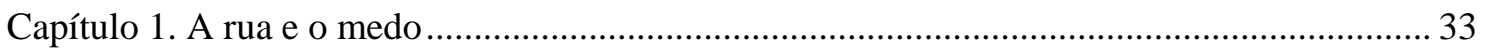

I. Cidade e assassinato: precedentes e impasses na figuração da violência urbana................. 33

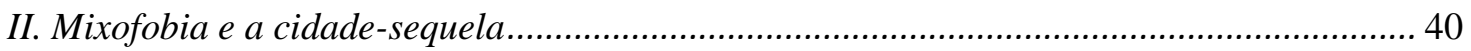

III. Desastre e evasão em Terminal, de Ronald Polito ......................................................... 46

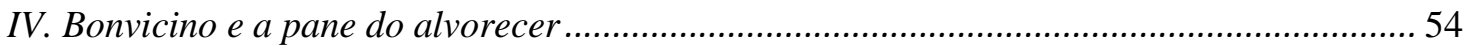

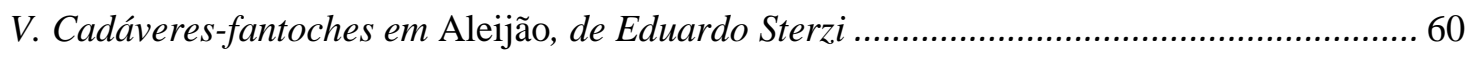

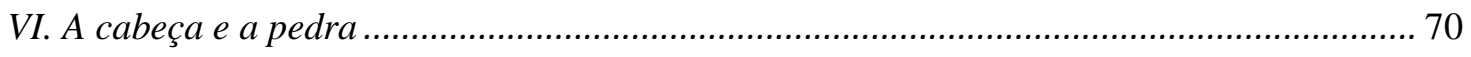

VII. Figurações da violência: recusa mimética $\times$ ansiedade referencial ............................... 76

Capítulo 2. "Se eu perder esse trem": verso e revés na cidade bloqueada................................. 81

I. "Circulando, circulando": paradoxos da mobilidade ..................................................... 81

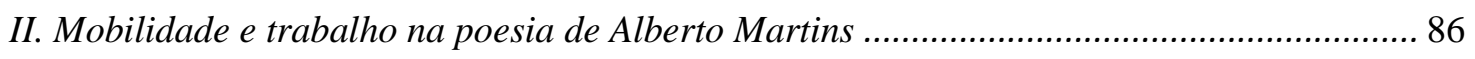

III. Encontros em movimento: intersubjetividade e circulação ............................................. 96

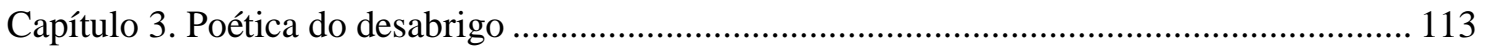

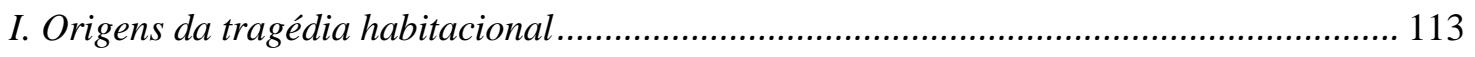

II. Sopro, ilusão e pedra: a cidade-puta na poesia de Pádua Fernandes.............................. 117

III. Porta da rua, serventia da casa: o desabrigo em Régis Bonvicino ................................ 130

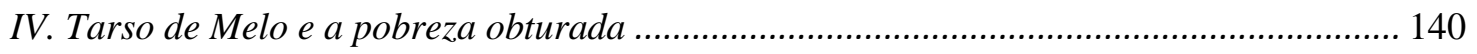

VI. Arrematando 
Capítulo 4. Cidades atemporais: entre a cópia e a queda.

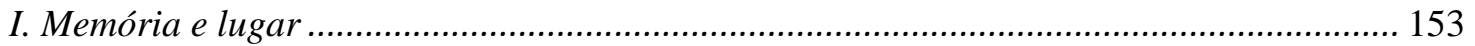

II. A queda e o calendário: o tempo na poesia de Paulo Ferraz .......................................... 157

III. A moça do outdoor e a Eurídice do novo: a tentação do inerte........................................ 178

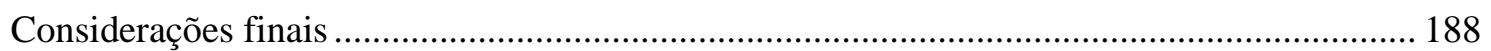

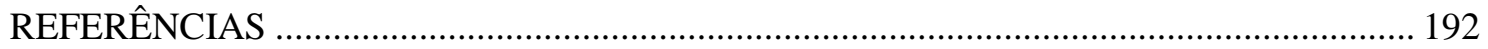




\section{Esclarecimento preliminar}

O texto a seguir constitui um desdobramento da pesquisa de mestrado com que ingressei no Programa de Pós-graduação em Teoria Literária e Literatura Comparada, em junho de 2007, tendo passado diretamente para o doutorado, em maio de 2010, após exame de qualificação. Ao longo desse período, ainda que meu objeto de pesquisa - as estratégias de figuração do espaço urbano na poesia brasileira contemporânea - não tenha mudado, efetuei algumas alterações significativas, sobretudo quanto à justificação de seu recorte, as quais gostaria de referir brevemente.

Em primeiro lugar, destaco a mudança em relação ao título original - "Sublimação e conflito: imagens da cidade na poesia brasileira contemporânea" -, que não indicava com clareza nem os limites concretos do "contemporâneo" visado pela pesquisa nem os eixos temáticos que orientavam a definição do corpus de autores e obras analisados. Em conformidade com aquele título, as imagens da cidade eram examinadas segundo uma polaridade algo esquemática, que as dividia entre representações em que os aspectos conflituosos da experiência urbana eram assumidos no nível temático-expressivo, sob a forma de tensões e dissonâncias, e representações nas quais aqueles aspectos eram de algum modo sublimados (estetizados, "espetacularizados", apaziguados, escamoteados, denegados) - estas últimas julgadas de maneira desfavorável em função do papel supostamente ideológico ou defensivo por elas desempenhado. $\mathrm{O}$ novo título proposto - "O tiro, o freio, o mendigo e o outdoor: representações do espaço urbano na poesia brasileira pós-1990" - explicita de saída tanto os eixos temáticos (violência, circulação, desabrigo e visualidade/temporalidade) a partir dos quais se investigam as representações urbanas como o recorte temporal adotado.

Ainda que o problema da assunção/neutralização dos conflitos continue a aparecer como preocupação nas análises, a ênfase sobre os eixos temáticos, definidos a priori com base em problemas urbanos contemporâneos, faz-se acompanhar de uma consideração mais larga dos poemas, atenta ao modo pelo qual certa parcela da poesia contemporânea oferece testemunho de determinados aspectos do drama citadino, como a estranha combinação entre fluidez e bloqueio em lugares onde a mobilidade é regulada pela renda ou os novos patamares da crise habitacional no contexto de "financeirização" da moradia e crescente 
segregação da pobreza. A eventual novidade desse testemunho poético e dos fenômenos que ele talvez flagre é aquilatada mediante comparações não sistemáticas com momentos anteriores de nossa poesia (e, mais pontualmente, da canção brasileira), em que temas semelhantes (como a violência em "Morte do leiteiro", de Drummond, o transporte público em "O bonde abre a viagem", de Mário de Andrade, ou a moradia precária em canções como "Saudosa maloca", "Despejo na favela" e "Abrigo de vagabundo", de Adoniran Barbosa) recebem tratamento diverso.

O último capítulo possui feição um pouco distinta dos anteriores, dedicados respectivamente aos temas da violência, da mobilidade e do desabrigo na obra de vários dos poetas aqui reunidos, a qual convém explicitar. Além do fato de nele se examinar a obra de um único poeta, Paulo Ferraz, o problema urbano que aí define o eixo temático - a relação entre a visualidade urbana (as imagens espetaculares, publicitárias, monumentais), a percepção do tempo e os efeitos de memória - também serve para discutir a atitude da poesia contemporânea em face da tradição pregressa (o legado do século XX) e dos impasses acarretados pelo longo interregno pós-utópico.

Em uma abordagem temática como a que se tenta aqui o risco é, nos piores casos, o da exterioridade em relação ao texto literário, frequentemente reduzido a mera ilustração dos problemas em apreço; o risco da aplicação mecânica, ao campo estético, de lições oriundas de outras áreas do conhecimento: urbanismo, antropologia, sociologia etc. Ciente disso, procurei ater-me à dimensão subjetiva em jogo na apreensão dessas "novas" configurações do urbano pelos poetas, de maneira que o eventual alcance coletivo de tais testemunhos não elidisse seu caráter íntimo e sensível.

Ainda no que concerne à natureza da abordagem e ao método de leitura, verificar-se-á, ao longo dos capítulos, um esforço de contextualização que, à perspectiva mais limitada da rua (o trânsito na rua, a violência na rua, o sem-teto na calçada), presente em muitos poemas, contrapõe comentários e explicações sobre os grandes movimentos da cidade, o que implica outro risco: o do descompasso entre os registros do local e do global, entre o tempo lento do poeta e do mendigo e o tempo rápido dos fluxos de capital e das decisões políticas. Tal descompasso poderia, de novo, trazer de contrabando blocos de explicação sociológica e urbanística que apontariam para elementos ausentes dos poemas. Procurei de todas as maneiras controlar esses "contrabandos", recorrendo à articulação 
entre rua e cidade (e às "macroexplicações") nos poemas em que ela me parecia indispensável - por exemplo, na análise de "Mapa progressivo do oco", de Pádua Fernandes, em que a voz dos moradores de rua se conecta à dos proprietários, à dos juristas, à da polícia, mas também à da própria cidade (personificada, erotizada) e à de seu antagonista, o cupim, "senhor dos senhorios", produtor do oco que é a contraface do patrimonialismo fundiário. Ou na análise dos poemas de Alberto Martins, em que as imagens de bloqueio do espaço e do trabalho figuram tanto a vulnerabilidade dos que vivem de pequenos bicos ou à margem do mercado como as forças econômicas que ordenam a produção da cidade, reservando áreas urbanas ociosas para fins especulativos.

Quanto ao recorte temporal, definido pela expressão "pós-1990”, vale dizer que, no começo da pesquisa, ele era justificado exclusivamente com base em uma transição percebida por alguns poetas e críticos como passagem de uma poesia predominantemente autorreferencial, indeterminada, desterritorializada, antimimética, "retradicionalista" (Simon, 1999) - isto é, uma poesia esteticamente desatualizada, indiferente à contradição entre modernidade artística concluída e modernização socioeconômica truncada e desigual -, produzida ao longo das duas últimas décadas do século passado, para um movimento de "retorno do real" (Simon, 2008), retorno às particularidades da experiência brasileira contemporânea. Tal "retorno" começaria a se delinear em fins dos anos 1990 sem, no entanto, interromper a voga retradicionalista, ainda bastante vigorosa nos dias de hoje.

Posteriormente percebi que esse recorte, apoiado em um hipotético ponto de virada na poesia nacional (em que é possível identificar, digamos, certo reavivamento da pesquisa estética), tinha sua pertinência reforçada pelo fato de coincidir com determinados marcos na constituição dos problemas urbanos que definem vários eixos temáticos da pesquisa. Senão vejamos: em primeiro lugar, no que concerne ao problema do desabrigo, durante os anos 1980-1990, em conformidade com a agenda neoliberal então em curso, testemunhamos o declínio do Banco Nacional da Habitação (BNH, extinto em 1986), a decisiva retirada dos investimentos públicos em habitação e saneamento e, mais recentemente, após o prenúncio de uma retomada das responsabilidades do Estado por meio de instrumentos como o Estatuto da Cidade, o Sistema Nacional de Habitação de Interesse Social, as Zonas Especiais de Interesse Social (previstas nos Planos Diretores dos municípios), assistimos ao desmanche do trabalho realizado pelo Ministério das Cidades, 
com a transferência para a iniciativa privada da incumbência de prover moradia e gerir o uso do solo (por meio do instrumento das concessões urbanísticas), o que elevou o preço da terra e incrementou a segregação territorial.

Em segundo lugar, no tocante ao problema da mobilidade urbana, que é multifatorial, ainda que as bases para o "apagão" dos transportes estejam dadas há muito tempo, em função da priorização do transporte individual pelas políticas públicas - em São Paulo, pelo menos desde os anos 1930, época da implantação do Plano de Avenidas, de Prestes Maia -, nota-se - ainda usando o exemplo São Paulo, que pode ser estendido a qualquer grande metrópole - como o descaso com o transporte público se agravou consideravelmente dos anos $1990^{1}$ em diante. Vale lembrar, porém, que o colapso na mobilidade tem alcance nacional e não se restringe ao âmbito dos transportes, abarcando a produção do espaço urbano como um todo, a qual favorece a mobilidade das classes com maior poder econômico. Nos últimos anos, a situação tornou-se de tal modo crítica que levou o governo federal a promulgar, em janeiro de 2012, a Lei 12.587, que institui as diretrizes da Política Nacional de Mobilidade Urbana, objetivando garantir, entre outras coisas, a equidade no "acesso dos cidadãos ao transporte público e coletivo" e no "uso do espaço público de circulação, vias e logradouros". ${ }^{2}$

Em terceiro lugar, no que se refere à violência urbana, as estatísticas comprovam seu incremento contínuo desde o começo da década de 1980, até o ponto em que, em fins dos anos 1990, nossas taxas de homicídio ficaram entre as mais altas do mundo ${ }^{3}$ - em São Paulo, algo da ordem de mais de 6.500 homicídios por ano, 10\% dos quais causados pela polícia, sendo o homicídio a principal causa mortis entre jovens, constituindo também um fator de redução (quatro anos a menos) da longevidade masculina na última década (Caldeira, 2011, p. 306).

\footnotetext{
${ }^{1}$ Biderman e Zarattini (2012) destacam a falta de subsídios para o transporte público que tem prevalecido em São Paulo desde a gestão Maluf, em 1993, ressalvando como medidas em prol da mobilidade a criação dos corredores de ônibus e a implantação do bilhete único, na gestão Suplicy. A queda progressiva na qualidade dos serviços de transporte público paulistano a partir de meados dos anos 1980 pode também ser aferida por meio da Pesquisa de Imagem dos Transportes na Região Metropolitana de São Paulo (2011).

${ }^{2}$ Lei Federal 12.587/2012, capítulo I, seção II, artigos III e VIII. Cumpre advertir que o terceiro capítulo desta tese, dedicado às representações poéticas da mobilidade urbana, foi escrito antes dos protestos pela redução da tarifa iniciados pelo Movimento Passe Livre. Esses protestos tomaram as ruas, espalharam-se pelo país e suscitaram outras demandas. Tais acontecimentos geraram grande quantidade de textos, cuja leitura será oportunamente incorporada à presente reflexão.

${ }^{3}$ Em artigo recente assinado pelos dois secretários de Segurança Nacional do governo Lula, Luiz Eduardo Soares e Ricardo Balestreri, em números absolutos o Brasil figuraria hoje como o segundo país mais violento do mundo, com uma taxa de homicídios dolosos da ordem de 50 mil por ano, $92 \%$ dos quais resultam impunes. (Balestreri e Soares, 2012).
} 
Assim, seja por razões internas à dinâmica da produção poética nacional, seja por razões externas, ligadas à sociedade brasileira e ao desenvolvimento urbano nas últimas três décadas, o marco "pós-1990” parece adequado a uma pesquisa sobre as representações poéticas da cidade correspondentes ao conjunto dessas transformações.

Por fim, quanto à composição do corpus de obras analisadas, procurei escolher autores em que os temas da segurança, da moradia, da circulação e da temporalidade urbanas aparecessem de maneira não episódica, constituindo uma questão importante em suas respectivas poéticas. Não pretendi criar uma tipologia exaustiva nem aferir a frequência de "soluções" encontradas para o enfrentamento dos temas escolhidos. Sem dúvida, outros autores poderiam ter sido convocados para a análise, a qual tem menos o caráter de um inventário abrangente que de um estudo de casos, sem aspiração generalizante. Tampouco me preocupei em criar uma amostra representativa em termos geográficos, de maneira a contemplar toda a gama de diferenças regionais na figuração do espaço urbano. Excetuando a menção pontual a autores e obras anteriores aos anos 1990, evocados para efeito de comparação no tratamento deste ou daquele tema, concentrei-me em um grupo de oito autores, a saber: Alberto Martins, Duda Machado, Eduardo Sterzi, Pádua Fernandes, Paulo Ferraz, Régis Bonvicino, Ronald Polito e Tarso de Melo. Trata-se de um conjunto relativamente heterogêneo, que mistura veteranos vates da urbe, em atividade desde a década de 1970 (caso de Machado e Bonvicino), a poetas mais jovens, a maioria estreante entre os anos 1990 e 2000 (Fernandes, 2002; Ferraz, 1999; Martins, 1990; Melo, 1999; Polito, 1996, Sterzi, 2001).

Além disso, mesmo que varie a cidade natal dos poetas em foco (Cuiabá, Juiz de Fora, Porto Alegre, Rio de Janeiro, Salvador, Santo André, Santos etc.), São Paulo emerge como cenário comum a muitos poemas, sem que isso imprima necessariamente um suposto "viés paulistano" à amostra, pois, a despeito da menção eventual a logradouros ou personagens específicos, os desafios representacionais mobilizados por esse campo de referências dizem também respeito a outras megalópoles.

Ainda no que diz respeito ao conjunto de autores selecionados, chamei-o há pouco de "heterogêneo", mencionando diferenças geracionais e de percurso entre eles. Tal caracterização foi, entretanto, refutada pelo urbanista Pedro Arantes, membro da banca de qualificação, que, adotando outro critério classificatório, considerou a amostra bastante 
homogênea (poetas de classe média/média-alta, com alto grau de instrução etc.) e sugeriu um contraponto com os poetas da periferia (de outra extração social e nível de instrução), até mesmo rappers, cuja produção talvez captasse melhor a convulsão urbana e certos aspectos do Brasil contemporâneo pouco evidentes na amostra com que trabalhei.

Infelizmente tal sugestão, que tem todo o interesse, não pôde ser acolhida porque impediria (ou dificultaria sobremaneira) a comparação (de procedimentos, estratégias de formalização, recursos expressivos) entre as representações poéticas do espaço urbano nos últimos quinze ou vinte anos e aquelas praticadas ao longo do século passado, do modernismo até meados da década de 1970. Se no registro da poesia "universitária", de "classe média", faz sentido comparar o ônibus de Duda Machado com o bonde de Mário de Andrade, o áporo drummondiano com o cupim de Pádua Fernandes, no âmbito da poesia dita "periférica" ou de "expressão popular", sem fazer caso da imprecisão designatória, tais comparações seriam mais difíceis, em função de diferenças de repertório e limites na decantação da experiência literária novecentista. Assim, reitero que um dos propósitos desta pesquisa é avaliar eventuais mudanças nas representações do espaço urbano pela poesia letrada contemporânea à luz da relação que ela estabelece com seus antecedentes próximos. Remissões pontuais a outras tradições, como a da canção, não alteram tal propósito.

Um derradeiro senão que se poderia fazer a este trabalho liga-se a certa defasagem do pensamento urbanístico que o embasa em face de acontecimentos recentes, como as jornadas de junho deste ano, e outras mobilizações coletivas mundo afora, que afetam o diagnóstico sobre o futuro das cidades. Em artigo recente dos curadores da $10^{\mathrm{a}}$ Bienal de Arquitetura de São Paulo, lê-se que "a força contestatória de vários 'occupy' pelo mundo" e "experiências bem-sucedidas (ainda que contraditórias) de cidades como Medellín, na Colômbia", deslocam certo fatalismo dos anos 1990, "segundo o qual as cidades pareciam não ter alternativa a não ser entregar-se inteiramente ao capital financeiro e globalizado". Assim, se, de um lado, constata-se o absurdo de cidades totalmente convertidas em valor de troca (os autores do artigo mencionam o caso de um investidor de Pequim que se defendeu da acusação de ter feito mau negócio ao comprar um distrito-fantasma em Ordos, na Mongólia Interior, dizendo que ele apenas investiu em uma cidade "que não está sendo gasta"), de outro, veem-se práticas colaborativas e redes horizontais de ação tentando se 
reapropriar dos espaços públicos e "se contrapor de forma relevante à especulação imobiliária, ao consumismo e à predominância dos interesses privados" (Wisnik, Nobre e Nobre, 2013). Essa situação nos impeliria a rever a tradicional dicotomia entre as forças econômicas e políticas, que constroem a cidade, e a população, que dela se serve, obrigando a uma compreensão mais dialógica dos usos e fazeres que plasmam a complexidade urbana contemporânea.

Sem me eximir de responsabilidade por eventuais defasagens no que concerne ao debate urbanístico mais avançado (isto é, assumindo talvez certa dívida com o "fatalismo" crítico dos anos 1990 que, de resto, foi o marco escolhido para o recorte temporal da produção poética em exame), é preciso recordar que o recenseamento mais estrito desse debate não foi meu objetivo aqui. $\mathrm{O}$ recurso às contribuições teóricas do urbanismo, da sociologia e da antropologia urbanas para mim sempre teve papel ancilar, fornecendo um pano de fundo para verificar de que maneira certos fenômenos observados por tais disciplinas apareciam ou não nos poemas. Por seu turno, os poetas, que em momentos felizes da literatura conseguem antecipar-se à história captando, como "antenas da raça", o que está por vir, em outros, vão na rabeira dos galos de outros terreiros, voltando-se surpresos para o que, muito antes deles, alguns (oriundos, às vezes, até de segmentos considerados conservadores, como a indústria cultural) já haviam percebido. Desse modo, esses descompassos entre teoria, realidade e representação artística constituem por si só, objeto de discussão no decorrer da tese.

Para encerrar, gostaria de dizer que minha forma de olhar para a cidade na poesia brasileira contemporânea decerto é também marcada por meu próprio trabalho como poeta dedicado à experiência das ruas. Comento a obra de companheiros, alguns muito próximos, parceiros de tropeço e calçada. Quanto há de desvantagem ou benefício crítico nessa proximidade caberá ao leitor discernir.

\section{$* * *$}

Partes da tese foram apresentadas em congressos e encaminhadas para publicação em periódicos e livros. Um extrato do primeiro capítulo rendeu a comunicação "O tiro e a aurora: luzes sobre a violência urbana na poesia brasileira contemporânea", exposta em 
2010 no IX Congresso Jornadas Andinas de Literatura Latino-americana (Jalla), sediado no Instituto de Letras da Universidade Federal Fluminense (UFF). As análises dos poemas "Vivência", de Ronald Polito, e "Tatuagem enigmática", de Duda Machado, também no primeiro capítulo, foram publicadas respectivamente no dossiê "Imagens da devastação" ("Meu primeiro bunker: imaginário bélico em Terminal, de Ronald Polito"), número 20 da revista eletrônica Literatura e Autoritarismo, da Universidade Federal de Santa Maria (UFSM), e no volume 12 da revista eletrônica Texto Poético, da Associação Nacional de Pós-graduação e Pesquisa em Letras e Linguística - Anpoll ("Luto e tatuagem: violência e marginalidade na poesia de Duda Machado"), disponíveis em: <http://w3.ufsm.br/grpesqla/revista/dossie08/RevLitAut_art07.pdf> <http://www.textopoetico.com.br/index.php?option=com_content\&view=article\&id=202\& $\underline{\text { Itemid }=40>}$. O início do segundo capítulo foi publicado como resenha expandida do livro Em trânsito, de Alberto Martins, em Sopro: Panfleto Político-Cultural, número 74, ago. 2012, disponível em: 〈http://culturaebarbarie.org/sopro/resenhas/emtransito.html>. Acesso em: 30 jun. de 2013. E uma versão ligeiramente alterada do terceiro capítulo foi publicada na coletânea Caminhos da lírica contemporânea: ensaios, organizada por Simone Rossinetti Rufinoni e Tércio Redondo (São Paulo: Nankin, 2013). 


\section{Apresentação: desafios representacionais da cidade contemporânea}

Les rues contemporaines sont des apories.

Jean-Michel Maulpoix

Escrevendo contra a conversão do tema urbano em moda acadêmica, a crítica argentina Beatriz Sarlo graceja ao lembrar que

sempre há pessoas andando de um lado para o outro, sempre há uma história que se está perdendo e uma memória que procura (ou não procura) construir-se, sempre há sujeitos cindidos que não chegam a reconhecer-se em lugar algum, sempre esses sujeitos dão um jeito de usar o espaço construindo novos sentidos, seja ressemantizando práticas ou inventando práticas novas, sempre há algo de deriva e determinação, sempre há algo que passa ao privado e algo que se torna público em novos usos. (Sarlo, 2005, p. 104-5)

Com efeito, o apelo a fantasmas como o do flâneur benjaminiano, em textos que lamentam seu ocaso ou celebram sua permanência, não só enfraquece a originalidade teórica do conceito (referido a um contexto histórico específico, o da Paris do Segundo Império), mas também parece dar costas à urbe atual, que já não se apresenta como aquele sistema de fluxos e choques produtivos por meio do qual o poeta tinha insights, operava encontros, açulava a memória.

Como adverte Jean-Michel Maulpoix, hoje a rua

cede lugar às grandes vias expressas e aos itinerários obrigatórios e funcionais rumo aos espaços-tipo, espaços-prótese: a via de pedestres, o corredor para ciclistas, os shopping centers, com os inevitáveis entretenimentos, liquidações, vasos floridos por todo o verão e cascatas de gerânios cor-de-rosa, com flores duplas... Itinerários artificiais onde nem o flâneur nem o imprevisível têm mais lugar, pois aí tudo é "mignon", conveniente, preconcebido, já visto e indefinidamente replicável [...]. (Maulpoix, 2002, p. 78) 
O que se perde nessa nova lógica circulatória é justamente algo que estava no coração das ruas, que definia sua dimensão propriamente pública: certo equilíbrio entre intimidade e estranheza. Tal dimensão é criada por meio de uma série de regras de civilidade que devem levar em conta a distância que há entre estrangeiros, entre indivíduos de diferentes gostos, interesses, desejos e posições sociais. Ela nos prepara para o convívio com quem não conhecemos, com estranhos que detêm direitos, que não são excluídos.

Quando Haussman, prefeito de Paris à época de Napoleão III, desfez os bairros medievais onde se entocava a população miserável, ele criou oportunidades de encontro (e de atrito) entre classes sociais até então apartadas - a despeito do tecnicismo higienista de seu projeto modernizador, voltado para a segregação social. Tempos depois, tais oportunidades acabaram por se articular em torno da ideia de que as ruas pertenciam ao povo e serviram de combustível ideológico para os levantes revolucionários anteriores à Primeira Guerra Mundial.

Não obstante, à vocação da metrópole para a mistura e para o conflito seguiu-se outra concepção de modernidade, empenhada na neutralização das forças anárquicas despertas pelos bulevares arteriais. Conforme explica Marshall Berman, a solução encontrada por arquitetos como Le Corbusier foi justamente a de planejar cidades refratárias à "volátil mistura de pessoas e tráfego, negócios e residências, ricos e pobres". (Berman, 1986, p. 162). A rua moderna, entendida como espaço que acumula as funções de tráfego e comércio, passou a ser francamente combatida nesses novos modelos de urbanidade, cuja vigência se estende até os dias de hoje.

Claro que isso tudo falando em termos excessivamente genéricos. Em países como o Brasil, essa passagem não se deu de modo linear, ensejando o convívio entre elementos corbusianos e estruturas arcaicas, "pré-haussmanianas". De toda maneira, seja em países ricos, a exemplo dos europeus (onde a referência da cidade como espaço regulado por ideais democráticos ainda perdura, embora já não se realize), seja em países pobres, como os da África subsaariana, ou em desenvolvimento, feito o Brasil (em que a constituição de uma esfera pública nunca se deu de modo efetivo), o contexto pós-urbano das cidades globais, marcadas pela prevalência dos fluxos tecnológicos sobre os territórios, pede decerto operadores teóricos diferentes daqueles de que Benjamin se serviu para ler Baudelaire. 
Vale então dizer que, ciente de tais dificuldades, este trabalho apresenta-se como uma tentativa de investigação de distintas estratégias de figuração do ambiente urbano na poesia brasileira contemporânea produzida recentemente. Foge, porém, a seu escopo descrever e avaliar essas transformações do ponto de vista do urbanista ou do antropólogo. O objetivo é verificar de que maneira os poemas respondem (se é que o fazem) às referidas transformações.

\section{***}

Escrevendo acerca do impacto do crescimento urbano-industrial sobre os modernistas de 1922, mais especificamente sobre Pauliceia desvairada, Iumna Simon sugere que a experiência das grandes cidades só transforma profundamente a criação artística de determinado período quando se alteram os "modos de percepção e apreensão da realidade", afetando os "próprios mecanismos de construção do objeto artístico" (Simon, 1980, p. 33-4) - donde a opção da autora por abordar os efeitos literários da urbanização à luz das dissonâncias entre as representações temáticas e os procedimentos expressivos. Assim, se os poetas europeus oitocentistas negavam tematicamente a civilização industrial incorporando, não obstante, suas técnicas e recursos construtivos, com os modernistas brasileiros, as ambivalências de início se manifestaram pela celebração temática do progresso e pelo uso de formas expressivas ainda pouco apropriadas ao registro da modernidade. Esclarece Simon que, em Pauliceia desvairada, por exemplo, onde a visão da modernidade é mais humanística que futurista (mais próxima de Whitman e Verhaeren que de Marinetti), a novidade na exploração de recursos técnicos como o verso harmônico e polifônico (mais afeito ao "simultaneísmo" moderno que o verso melódico) não chega a quebrar com a linearidade lógico-discursiva, atestando não apenas a distância entre intenção e resultado, mas também uma hesitação construtiva relacionada às ambiguidades da modernização nacional. Já nos poemas oswaldianos de Pau-brasil, em que a temática urbano-industrial comparece de modo restrito, os procedimentos expressivos seriam mais 
avançados, abrindo uma fecunda vertente de experimentação retomada décadas mais tarde pela Poesia Concreta ${ }^{4}$.

A despeito da enorme diferença entre o contexto modernista ou concretista de urbanização e o das "anticidades" globalizadas, cuja influência sobre a poesia atual se deseja investigar, julgamos metodologicamente proveitoso o exame das tensões temático-expressivas em jogo nessa produção - o que nos defronta com a multiplicidade de ângulos a partir dos quais é possível operar.

A cidade pode ser observada a distância, de fora, do alto, apreendida como totalidade tentacular e nervosa, ou de perto, de dentro, pelo movimento dos pedestres, que escrevem corporalmente o texto urbano sem conseguir lê-lo ${ }^{5}$; pode ser descrita em termos predominantemente visuais, como cenário, com seus marcos arquitetônicos e brechas de paisagem, ou acústicos, como teatro de falas (por sua vez, passíveis de submissão a um ponto de vista único, ao filtro da primeira pessoa, à mediação retórica de um sujeito lírico uno e íntegro, ou sujeitas à mistura de registros, fragmentadas ou sobrepostas em arranjos corais).

No rol das possibilidades de figuração urbana, mencionem-se ainda a penetração do público na esfera doméstica - a intimidade dos locais protegidos em que a cidade, sem ser referida diretamente, "é empurrada para as margens da representação [...] postulada como arredor e como condição de uma forma de consciência e de um estilo de vida" (Durand, 2004, p. 81) -, a erotização do espaço (a cidade como organismo, corpo - sedutor ou enfermo) ou o uso defensivo de imagens da natureza contra os aspectos conflituosos da sociabilidade urbana.

\footnotetext{
${ }^{4}$ A relação entre a poesia oswaldiana e concretista e o progresso urbano-industrial foi objeto de críticas posteriores, que convém mencionar. Em "O bonde, a carroça e o poeta modernista", Roberto Schwarz demonstra como Oswald "perseguia a miragem de um progresso inocente", que acomodava "o moderno-de-província, o moderníssimo e o arcaico" no plano temático e também no dos procedimentos expressivos, cujo anticonvencionalismo desempenhava papel ideológico, funcionando como "penhor de identidade nacional" (Schwarz, 1987, p. 24-5). Simon por seu turno, em "Esteticismo e participação", acusa a enorme carga de idealização nos concretistas dos anos 1950. Neles, o desejo de participação, de instrumentalização política da poesia, em um momento em que a modernização social e o desenvolvimento técnico e científico ainda eram uma promessa, aliava-se a um ideal de pureza artística (assepsia, acabamento, clareza estrutural) e a uma visão ingênua do progresso, capaz de criar "uma espécie de mundo de sonhos, produtivista, coletivizado e racional." (Simon, 1990, p. 137). Quanto à falta de negatividade do esteticismo concretista (a vanguarda purgada das estratégias de choque e agressão, do ímpeto antiburguês, ciosa de reconhecimento e institucionalização como arte de massa), vale dizer que, mutatis mutandi, ela continua ativa em poetas de gerações mais novas, de certa maneira herdeiros desses modelos. Ver a esse respeito as considerações sobre a "negatividade ornamental" na poesia de Carlito Azevedo (Simon; Dantas, 2011).

${ }^{5}$ Jean-Cristophe Bailly (1992, p. 23-4, apud Mongin, 2005, p. 70) postula a esse respeito a existência de uma "gramática gerativa das pernas", sendo também bastante conhecidas as considerações de Michel de Certeau sobre o papel da motricidade pedestre na definição da forma citadina (uma forma sem receptáculo físico). Certeau (1994) oporá a cidade-panorama das utopias urbanísticas, comprometidas com a administração panóptica, a disciplina e a ideologia do progresso, à microurbanidade das práticas do cotidiano, ligadas a uma experiência da cidade mais mítica e contraideológica. Também o crítico Alfonso Berardinelli refere-se a dois extremos entre os quais oscila a representação da cidade nos "Tableaux parisiens" de Baudelaire: de um lado, a visão de conjunto, panorâmica, que apreende a cidade do alto, como um fundo "confortável", que não perturba nem aflige (caso do poema de abertura, "Paysage"); de outro, a modalidade do encontro e do choque (conforme se vê em "À une passante"), "que arrasta quem escreve" (Berardinelli, 2007, p. 146).
} 
Vale também discernir, em meio à pluralidade de caminhos, o alcance crítico desses versos abertos para a rua: saber se o poema se limita à descrição denuncista, documental, à crônica das mazelas do cotidiano, à espetacularização da miséria, da violência; se o poeta paira acima do desastre, intocado demiurgo da linguagem, ou se é por ele levado de roldão, sendo afetado em seu modus poetandi; se o discurso de fato reconfigura nossa sensibilidade e encontra equivalentes formais para as instabilidades sociais de que é contemporâneo.

Conforme adiantamos no esclarecimento preliminar, o recorte cronológico adotado na escolha do material de análise justifica-se com base no que os próprios poetas têm percebido como uma mudança nos rumos da poesia brasileira produzida nas duas últimas décadas. Declara Alberto Martins em depoimento concedido, em maio de 2002, no projeto "Poetas na Biblioteca", da Fundação Memorial da América Latina:

Uma coisa muito forte para quem, como eu, entrou na Letras em 1976, com dezessete anos, era, por um lado, a presença de um Concretismo muito rigoroso, enfático, dogmático e, por outro, a poesia marginal. Existencialmente, sentia-me mais próximo da poesia marginal, mas aquilo também não me satisfazia em termos de construção literária, não me reconhecia naquilo.

Acho que isso também tem a ver com a maneira pela qual o Mallarmé foi assimilado aqui no Brasil. Uma coisa é você ler Mallarmé na Europa, no seio daquelas literaturas constituídas. Outra coisa é, num país cheio de lacunas, esgarçado culturalmente, num momento de ditadura, de fechamento, o consórcio entre o niilismo mallarmaico e a nossa falta histórica de acesso ao real.

Isso gerou uma matriz poética, dentro da qual concebi meu primeiro livro [em 1990], que tem muita dificuldade de aceder ao real. Lembro uma frase que está em Três mulheres de três pês, do Paulo Emílio, um livro de fins dos anos 70, em que ele diz: "Eu morava em Pinheiros, ela, em Perdizes. Assim, nunca nos encontrávamos". Eu li e logo pensei: "Poxa, isso é São Paulo!”. Era tão difícil nomear a experiência da cidade que essa frase me pareceu emblemática. Hoje isso parece ridículo, não é? Mas, para quem lembra essa época, reconhece o que estou dizendo.

Hoje, há muito mais matrizes, muito mais frescor na poesia contemporânea. É mais fácil pra rapaziada de hoje do que foi pra gente. Ainda reconheço essa matriz mallarmaica, de esquiva em relação ao real em muita 
poesia que se faz agora, mas é uma atitude entre outras. Como o real brasileiro dá margem a essa relação de esquiva, acho que essa matriz pode ainda vigorar. Mas o que é que o artista em verdade deseja? Estirar ao máximo o arco dos seus recursos e trazer porções de realidade cada vez maiores. Por isso, a matriz mallarmaica é complicada, não pela qualidade das questões que coloca, mas pelo imbricamento com a experiência histórica brasileira e seu caráter lacunar. Isso é uma coisa que eu queria deixar marcada, sobretudo na conversa com os poetas mais jovens. (Martins, 2004, p. 204-6) ${ }^{6}$

Tal percepção encontra eco em depoimento de Carlito Azevedo, feito quase na mesma época:

[...] passamos por uma transformação radical do que se chamou cidade. Cidade como bem caracterizou o Baudelaire, era a rua, estar nas ruas, na multidão, e ali apagar-se, ali perder-se. A informatização e o conforto, por um lado, e, por outro, o medo da violência, da bala perdida, do sequestro-relâmpago, esvaziaram as ruas que, ao mesmo tempo, passaram a ser a única morada para os excluídos, os "excedentes", segundo a terminologia cínica da globalização. Acho que, sob o signo de Baudelaire, o que esses poetas estão fazendo é sismografar essa nova revolução urbana que vai transformar singularmente nossa sensibilidade. (Azevedo, 2001, p. 5)

Em sintonia com tais preocupações, Sérgio Alcides, também em depoimento ao projeto "Poetas na Biblioteca", reivindica uma dimensão civil e republicana para a poesia, fundada no atrito entre experiência e linguagem:

Penso muito na relação que a poesia tem com o espaço público, com a vida em comum das pessoas, além da relação, mais evidente, com o espaço da intimidade. De repente, me lembrei do Brossa, um catalão que era um poeta republicano. [...] Um poeta republicano é alguém interessado nessa epiderme que é ao mesmo tempo interseção, interessado nesse espaço em que as pessoas estão vivendo, em que o corpo está envolvido, assim como o face-a-face com o

\footnotetext{
${ }^{6}$ Vale insistir quanto ao fato de que foi nossa dificuldade histórica de acesso ao real que propiciou tal leitura de Mallarmé, que não necessariamente precisa ser lido dessa maneira. Para uma leitura política desse autor, ver Rancière (1996).
} 
outro. O poeta republicano quer construir sua poesia nessa fronteira da pele com o mundo civil, o mundo do outro, do próximo. [...] A memória da cidade também trabalha entre pele e civilidade. Há uma frase do Bernardo Soares, figura de existência discutida, um heterônimo de Fernando Pessoa, no Livro do desassossego, que me ajuda a fundamentar essa ideia. Ele diz: "Minha consciência da cidade é, por dentro, a minha consciência de mim”. Essas duas consciências estão ligadas de uma maneira que não sei se é concêntrica, mas talvez seja mutuamente excêntrica; ou paralelamente excêntrica.

Não existe esfera pública sem alguma medida de teatralidade. A ideia de civilidade está imbuída de uma série de dispositivos morais, de comportamento, que são pensados, calculados, aprendidos, que têm uma dimensão de teatralidade, de espetacularização. A crítica à sociedade do espetáculo não pode ir tão longe a ponto de supor que é possível uma convivência civil sem o theatrum mundi. [...] Por que isso é interessante numa conversa sobre poesia? [...] Já que estou fazendo essas pontes analógicas entre o espaço público, o espaço do $e u$, a cidade, a linguagem, a pessoa... Vamos lembrar que a poesia tem uma dimensão retórica do espetáculo. Digo na entrevista que a poesia hoje está muito espetacularizada, que são muitos efeitos, muitas aliterações, muitos jogos de linguagem, muita firula. Continuo pensando assim, mas eu precisaria complementar um pouco essa ideia. [...] A poesia tem, sim, uma dimensão retórica, mas não pode ser reduzida a isso. Sem isso ela é pouca coisa, mas sendo só isso ela é nada. Da mesma forma, a sociedade precisa de alguma medida de espetacularização para que haja civilidade, mas a própria civilidade fica esmagada se a sociedade for reduzida ao espetáculo. (Alcides, 2005, p. 16-8)

Vale ainda notar que tal preocupação dos poetas com o "espaço público" coincide com um processo de ideologização desse conceito no discurso urbanístico. Tal processo, descrito por autores como Fiori Arantes (2000), Paquot (2009) e Delgado (2011), refere-se ao uso retórico do conceito, não apenas por arquitetos e urbanistas, mas também por políticos, em que o espaço público passa a ser o sítio no qual se materializam categorias abstratas como civismo, democracia e consenso, e que acaba muita vez servindo para legitimar iniciativas de apropriação capitalista da cidade. 
Manuel Delgado mostra como, no campo das teorias sobre a cidade, tal uso ganha força a partir dos anos 1990, referindo-se a sua quase ausência na obra de autores como Jane Jacobs, Jean-François Augoyard, Kevin Lynch, Henri Lefebvre, Jordi Borja e William H. White, entre outros. Lembra o autor que a expressão "espaço público" nesses textos anteriores à década de 1990 é utilizada na maioria das vezes de maneira genérica como designação dos "espaços abertos e acessíveis da cidade, para o que alguns têm preferido usar a expressão “espaço urbano"” (Delgado, 2011, p. 17).

Thierry Paquot, por seu turno, destaca a não correspondência entre o singular e o plural da expressão "espaço público": o primeiro, sinônimo de esfera pública, remeteria ao âmbito do debate político, da exposição pública de opiniões privadas, ao passo que o segundo corresponderia ao conjunto de ruas, praças, parques, jardins e demais espaços de circulação abertos ao público. A partir de certo momento, porém, ocorreria uma identificação entre o sentido político e o tópico, devida ao "cruzamento da geografia e de uma certa interpretação da obra de Jürgen Habermas.” (Paquot, 2009, p. 88)

Rastreando desde fins dos anos 1960 as raízes dessa ideologia do "lugar público", Otília Fiori Arantes nos adverte que Habermas associa a instituição de uma esfera pública comunicacional não coercitiva e a formação da vontade democrática "sem, no entanto, ter ilusões quanto ao seu complemento urbano". Ao contrário de Hannah Arendt, que idealiza a ágora grega buscando para ela um equivalente moderno em que a forma urbana coincida com o corpo político, Habermas sabe que "a forma de vida exigida como suporte e alimento do mundo público a ser recomposto à contracorrente do capitalismo avançado já não pode contar mais com a forma abarcável da cidade." (Fiori Arantes, 2000, p. 117)

Apesar disso, a tal confusão entre o sentido tópico e o político do espaço público acaba por se disseminar sob a forma do "cidadanismo", que, ainda segundo Delgado, forneceria abrigo para "os restos de esquerdismo da classe média", equivalendo a um tipo de "democraticismo radical que trabalha na perspectiva de realizar empiricamente o projeto cultural da modernidade em sua dimensão política, entendendo a democracia não como regime de governo, mas como modo de vida e associação ética". Prossegue o autor dizendo que é 
isso o que faz com que uma rua ou uma praça sejam algo mais do que simplesmente uma rua ou uma praça. Elas são ou devem ser o proscênio em que a ideologia cidadanista pretende ver a si mesma como realidade, o lugar em que o Estado logra desmentir momentaneamente a natureza assimétrica das relações sociais que administra (e às quais serve) e encena o sonho impossível de um consenso equitativo no qual pode levar a cabo sua função integradora e de mediação.” (Delgado, 2011, p. 21, 28). ${ }^{7}$

Retornemos, contudo, à poesia. Haja ou não algum nexo entre a importância crescente, da década de 1990 em diante, do espaço público como valor ideológico na retórica político-urbanística e a percepção, por alguns poetas, de que era preciso voltar a pensar na relação entre poesia e cidade, fato é que também no campo da crítica literária, mais ou menos na mesma época, percebem-se sinais de mudança. Iumna Simon (2008), por exemplo, distingue na poesia que começa a surgir a partir daí uma inflexão na tendência “desrealizante" que orientou muitos dos projetos poéticos desenvolvidos durante a década de 80 (e em boa parte de década seguinte), respondendo com conservadorismo ao momento histórico de regressão social e estagnação econômica por que passava o Brasil.

No entanto, ainda segundo a autora, em vários trabalhos surgidos desde fins dos anos 1990, seria possível identificar sinais de uma volta à referência concreta (aos problemas sociais de um tempo e de um lugar específicos), espécie de "retorno do real", cujas razões pedem exame e os resultados, avaliação e julgamento.

Simon emprega o termo inspirada pelo trabalho do crítico norte-americano Hal Foster, autor de The Return of the Real, de 1996. Relendo a história das vanguardas no campo das artes plásticas, Foster identifica uma mudança, sobretudo com base em obras feitas na última década do século $\mathrm{XX}$, marcada por experiências de abjeção e violência extremas, uma transformação no conceito de realismo, o qual passa a ser compreendido menos como efeito de uma representação e mais como evento traumático, força de interrupção sobre o vínculo do espectador com um real outrora pacificado e encoberto pela mediação simbólica e imaginária do regime representacional. Trata-se de um real em acepção psicanalítico-lacaniana, o real como o que resiste à simbolização e cuja emergência

\footnotetext{
${ }^{7}$ Um dos principais problemas acarretados pela transformação de um espaço teórico em espaço sensível é que o direito ao anonimato, que é precondição para a igualdade comunicacional, é desmentido por desigualdades na estrutura social, constituindo, em verdade, prerrogativa de uma pequena burguesia universal para quem está pensado todo o sistema (Delgado, 2011, p. 62).
} 
é fonte de angústia. Sua repetição compulsiva não equivaleria exclusivamente nem à representação de um referente nem à simulação de uma imagem, diferenciando-se, por conseguinte, tanto do modelo referencial como do modelo autorreferencial inerente à noção de simulacro. A novidade das representações contemporâneas, para Foster, estaria no fato de elas serem, ao mesmo tempo, referenciais e simulacrais, forjando imagens simultaneamente conectadas à realidade e dela desconectadas, imagens ao mesmo tempo reais e artificiais.

Além de Simon, a influência de Foster pode ser verificada ainda na obra de outros críticos . Karl Erik Schøllhammer (2011, 2012), por exemplo, extrapola as considerações de Foster sobre as artes plásticas para outros campos artísticos (literatura e cinema) e contrapõe seu "realismo traumático" seja à demanda de verossimilhança e objetividade histórica do realismo oitocentista, seja à confiança na força referencial dos realismos novecentistas, criticamente conscientes da distância entre o real e sua encenação (como ocorre no anti-ilusionismo brechtiano). ${ }^{8}$ Desse realismo extremo, destacar-se-iam o caráter performático (efeitos sensíveis e mortificantes sobre o receptor) e indicial (por exemplo, na autoficção contemporânea, que estabelece uma relação metonímica com o real por meio de índices - nomes próprios, citações, fotos - que, em vez de “documentar”, projetam sombras sobre o texto). ${ }^{9} \mathrm{O}$ crítico trabalha então com a hipótese de um realismo em que os efeitos de realidade "atuem afetivamente pela expressão textual em um nível que só pode ser denominado de não hermenêutico", de um realismo que "conjuga as ambições de ser 'referencial' sem ser representativo"' (Schøllhammer, 2012, p. 143).

Outro ponto interessante nas considerações de Schøllhammer sobre o realismo traumático liga-se ao pretenso efeito "antiespetacularizante" do trauma que, ao intensificar a tática de choque amplamente empregada na publicidade, no jornalismo, nos freak shows da indústria de entretenimento, destina-se a "romper a anestesia cultural da realidade

\footnotetext{
${ }^{8}$ Sobre o relativismo do nexo entre realismo e verossimilhança (já no contexto oitocentista) e sobre o uso realista da deformação, consulte-se com proveito o célebre ensaio "O realismo artístico", de Roman Jakobson (1987), publicado originalmente em 1921.

${ }^{9}$ Schøllhammer menciona o papel diversionista desses indícios em obras da prosa de ficção brasileira contemporânea, como Nove noites, de Bernardo Carvalho, Capão Pecado, de Ferréz, Angu de sangue, de Marcelino Freire e Treze, de Nelson de Oliveira (Schøllhammer, 2012, p. 140). Contudo pode-se pensar em exemplos mais recentes, como a novela Opisanie Świata (2013), de Veronica Stigger, em que o uso de fotos, postais e anúncios servem menos para fixar temporalmente a narrativa que para alimentar a imaginação do espaço e da gestualidade das personagens que o habitam. De modo semelhante, vale ainda lembrar o uso ficcional da forma "diário" no romance Divórcio, de Ricardo Lísias (2013), e na autonomia que seu narrador reivindica em relação a qualquer imperativo de verossimilhança. Afirma ele, cujo nome é o mesmo do autor: "A verossimilhança deixou de ser um imperativo para a ficção. O mundo real não oferece mais bases sólidas. Mesmo a certeza de que não morri e acabei dentro de um romance meu precisou ser refeita através de tratamento psicanalítico". (LísIAs, Ricardo. Divórcio. Rio de Janeiro: Objetiva, 2013, p. 198). Victor da Rosa (2013), em resenha sobre Divórcio, serve-se igualmente do trauma fosteriano para comentar o romance.
} 
espetacular, propondo um choque do real que já não pode ser integrado ou absorvido no próprio espetáculo”. O próprio crítico, porém, reconhece certa ambiguidade nessa conceituação do trauma como algo capaz de, ao mesmo tempo, resistir ao espetáculo e dele participar na medida em que: a) trabalha com experiências muito próximas daquelas exploradas pela mídia, sofrendo a concorrência desta e b) favorece a reemergência do confessionalismo e a capitalização sensacionalista do diferencial (auto) biográfico de suas vítimas, convertendo-se em moda (Schøllhammer, 2011, p. 85 e 88).

Trabalhando também com as mutações do realismo na prosa de ficção contemporânea, na Argentina e no Brasil (lidando com autores como Sérgio Chejfec, César Aira, João Gilberto Noll, Caio Fernando Abreu e Luiz Ruffato), Luz Horne (2011) verifica que, embora ao longo do século XX nunca tenha deixado de haver literatura realista (a despeito da aura retrô associada ao termo a partir dos anos 1970, em função da crítica estruturalista), ocorreria, da década de 1990 em diante, certa intensificação dos “discursos sobre o real" (que excedem a estética realista em sentido estrito), não apenas no plano artístico (retorno a certos temas, miserabilismo, foco em aspectos baixos, animalescos da vida em sociedade, desejo de oferecer um testemunho do tempo presente etc.), mas também no da crítica, o que Horne relaciona à "agudização da desigualdade social, da pobreza e da violência nas grandes cidades latino-americanas" (Horne, 2011, p. 13). Na prosa de ficção, o diferencial dessa "nova" onda realista estaria, ainda segundo a autora, na assimilação a contrapelo de certos recursos das vanguardas históricas (descontinuidade narrativa, fragmentação, acolhimento de formas não linguísticas, desestabilização textual), sem desaguar na autorreferencialidade. Trata-se, pois, de um realismo que recorre ao inverossímil e à interrupção da ordem simbólica como via de acesso ao extraliterário e de intervenção sobre ele.

Horne retoma a crítica barthesiana à disciplina realista - que advoga em favor da semiose contra a mimese, em favor da escritura contra a compulsão significante, contra a epistemologia do detalhe, contra o impulso moralizante (e o gozo do patológico) naturalista - ao mesmo tempo que assinala, no retorno do real que se dá a partir dos anos 1990, uma saída alternativa para a crise representacional. Também ela, como Schøllhammer, recorrerá à ideia de um realismo performativo e indicial, em que os elementos da realidade não são inseridos em um continuum explicativo que lhes retira a força. Se o enlace referencial se 
conserva, é dentro de estruturas voláteis (como em certas instalações) e, se há ilusionismo, ele se prende mais a efeitos de materialidade que de realidade. Nas palavras da autora, trata-se de um realismo que substitui

o "efeito de real" (Barthes), onde as leis de verossimilhança eram um elemento-chave, por um "efeito de materialidade" ou um "efeito indicial”, onde já não importa se persiste algo de verossímil na composição ou se a coerência textual fica interrompida; o que interessa é que se faça "como se" o texto pudesse conservar certos traços materiais ou corporais próprios do real. (Horne, 2011, p. $116)^{10}$

Tal indicialidade não disfarça sua natureza ficcional: ela não remete a uma realidade mais profunda ou autêntica, como ocorria com os experimentos surrealistas. ${ }^{11}$ Os elementos indiciais e oníricos passam então a valer por sua ausência metafórica, menos pelo significado que ocultam que por sua repercussão sensível (nonsense performativo).

Com foco na prosa de ficção, Horne vai enfatizar a linguagem direta, ostensiva, sem excessos retóricos, bem como o esforço de detenção do tempo em palavras-imagem como componentes importantes na construção do realismo sensível/indicial das narrativas com que trabalha - aspectos que certamente têm peso muito diverso na obra dos poetas de que nos ocuparemos aqui. Sendo a poesia um gênero mais afeito à descontinuidade e à condensação imagética, veremos mais adiante como certos congelamentos temporais (por exemplo, em alguns poemas de Bonvicino sobre moradores de rua, em que a vocação pictural, o colecionismo fotográfico e a estabilidade escópica pacificam as tensões inerentes ao cenário voyeurizado pelo poeta ${ }^{12}$ ), bem como o uso de barroquismos e outros recursos

\footnotetext{
${ }^{10}$ Lidando com o cinema brasileiro contemporâneo e mostrando como ele pode constituir um contradiscurso à administração do imaginário perpetrada pela tevê, Ismail Xavier também retoma a noção barthesiana de "efeito de real" mostrando como certos filmes hoje, sobretudo no campo do documentário, "se mobilizam para produzir um certo efeito-do-real por diferença, o que permitiria o recurso a uma noção de 'realismo' como traço diferencial, em que um discurso ou um estilo atesta sua potência de revelação por sua oposição à convenção sedimentada e aos discursos que já se fizeram clichês". (Xavier, 2010, p. 17) A propósito do documentário Ônibus 174, de José Padilha, Xavier destaca a combinação entre procedimentos da narrativa realista clássica (a alternância entre o fim trágico do sequestro, com morte da refém e do sequestrador, e entrevistas que apresentam a vida deste em retrospectiva, conferindo sentido a seu desfecho) e o que o crítico chama de microrrealismo (uso da câmera-lenta e de repetições que interrompem o fluxo da ação, ensejando o comentário das vozes), o qual se liga à exploração ficcional da indicialidade, que Xavier denomina "teatro de evidências".

${ }^{11}$ Isso fica claro, por exemplo, nos experimentos de autoficção em que o elemento autobiográfico não é sinônimo de autenticidade, mas componente de um jogo entre autor real e vida inventada.

${ }^{12}$ Em orelha ao mais recente livro de Bonvicino, Estado crítico (São Paulo: Hedra, 2013), que não foi objeto desta tese, o crítico Alcir Pécora sustenta opinião contrária, afirmando que as imagens recolhidas por Bonvicino permanecem em estado de permanente colisão: "Essa estratégia de choque imanentista raramente se resolve numa pintura mais caprichada dos objetos, mas sim numa narrativa capaz de mantê-los em ação. Daí os surpreendentes travellings ou, ao contrário, as elipses agudas, nos quais a sucessão paratática se entrega,
} 
retóricos (por exemplo, na obra de Pádua Fernandes, que se serve desses expedientes para conectar a crise habitacional contemporânea a traços arcaicos de nosso passado colonial), podem, em verdade, ter efeito contrário ao descrito por Horne nos prosadores que ela examina.

No entanto, a despeito das diferenças quanto ao que o retorno do real subsume em diferentes campos (na prosa, na poesia e nas demais artes), podemos discernir, entre críticos de distintas orientações teóricas, alguma convergência na consideração do pós-1990 como marco de uma nova voga realista ou ao menos para certo cansaço em face da autorreferencialidade como saída privilegiada para a crise representacional.

Acrescentem-se a essas justificativas para o recorte temporal outras, relacionadas a três dos quatro eixos temáticos que orientaram a pesquisa: segurança, circulação e moradia. Repetindo o que se disse no esclarecimento preliminar, os anos 1990 também definem um período de grande incremento da violência nos grandes centros urbanos do Brasil, bem como de recuo de investimentos e desmantelamento de políticas públicas nas áreas de transporte, habitação e saneamento, conforme evidenciaremos nos próximos capítulos. Neles serão analisados mais detidamente poemas de livros publicados entre 1997 e 2011, embora também sejam invocados, a título de contraponto, outros poemas e algumas canções, que remontam até os anos 1940.

Desnecessário esclarecer que a divisão dos poemas em capítulos dedicados a temas exclusivos não impede a sobreposição de temas em determinado poema nem a presença de um mesmo autor ou de uma mesma obra em mais de uma seção da tese, é claro.

Veremos então um primeiro capítulo dedicado ao tema da segurança em que, após breve excurso com dois exemplos de representação poética de homicídios em poemas anteriores ao período aqui visado (um dos anos 1940, outro dos anos 1970), trataremos dos impasses concernentes à figuração das formas contemporâneas de violência em poemas dos livros Céu-eclipse (1999), de Régis Bonvicino, Terminal (2006), de Ronald Polito, Aleijão (2009), de Eduardo Sterzi, e Cinco lugares da fúria (2008), de Pádua Fernandes.

Em seguida, enveredaremos pelo tema da mobilidade urbana e da combinação paradoxal entre fluidez e paralisia associada à segregação territorial e à precarização do transporte público. Nesse capítulo, dedicar-nos-emos primeiramente ao livro Em trânsito 
(2010), de Alberto Martins, verificando o lugar central da ideia de trânsito e a multiplicidade de sentidos que ela enfeixa na obra poética de Martins e também em seu trabalho como artista plástico. Em um segundo momento, nos ocuparemos mais especificamente das tensões produzidas por encontros intersubjetivos no transporte coletivo. Aí, após uma rápida carona no bonde marioandradino de Lira paulistana (1945), analisaremos poemas de Duda Machado, Tarso de Melo e Paulo Ferraz.

Ato contínuo, desaguaremos no tema da moradia precária e do desabrigo. Em "Mapa progressivo do oco", suíte de poemas também extraída do livro Cinco lugares da fúria (2008), de Pádua Fernandes, focalizaremos os processos de erotização dos espaços públicos e do sadismo "higienista" que os toma por alvo. Depois nos concentraremos em representações poéticas dos moradores de rua nos livros Céu-eclipse (1999) e Página órfã (2007), de Régis Bonvicino, e Lugar algum (2005) e Exames de rotina (2008), de Tarso de Melo.

Por fim, com base em poemas de Paulo Ferraz, dos livros Constatação do óbvio (1999), De novo nada (2007) e Evidências pedestres (2007), refletiremos sobre a percepção do tempo e a produção de memórias no ambiente urbano, fonte de imagens e sinais cuja repetição ou interrupção (a cópia ou a queda, como se lê em um subtítulo desse capítulo) abre também caminhos para pensar a relação da poesia brasileira contemporânea com a literatura pretérita.

Conforme advertimos, ao longo dos capítulos aproveitar-se-ão contribuições teóricas ao estudo da cidade oriundas de disciplinas como o urbanismo, a sociologia e a antropologia urbanas, sem perder de vista a mediação poética das tensões inerentes à vida nas ruas. 


\section{Capítulo 1. A rua e o medo}

I. Cidade e assassinato: precedentes e impasses na figuração da violência urbana

O poeta e antropólogo Antônio Risério principia ensaio recente sobre segregação urbana ("Sertão, cidade, segregação"), evocando, por meio do teólogo Jacques Ellul, o vínculo existente entre cidade e assassinato no texto bíblico:

E Caim construiu uma cidade para substituir o jardim divino. A cidade é fruto da Queda. Refúgio da humanidade expulsa do sítio paradisíaco. E seu fundador foi o primeiro assassino de que se tem notícia. Deus fez o primeiro jardim - Caim, a primeira cidade. (Risério, 2012, p. 173)

Se o primeiro assassino, fratricida proscrito, foi também o primeiro arquiteto, o tema da violência constitui um rubicão incontornável para qualquer estudo sobre as representações poéticas do espaço urbano. Gostaria então de começar este capítulo com dois poemas sobre assassinato e cidade: um dos anos 1940, de um livro-emblema de nossa melhor poesia política, A rosa do povo (1945), de Carlos Drummond de Andrade, e outro dos anos 1970, de um livro relativamente pouco conhecido, Zil (1977), obra de estreia de Duda Machado. Trata-se de poemas escritos em momentos de grande repressão política, o Estado Novo e a ditadura militar, e que de cara nos confrontam com alguns desafios talvez úteis para pensar nos destinos da poesia posterior, às voltas com dificuldades semelhantes, ainda que em contextos históricos diversos.

Em "Morte do leiteiro", um dos mais célebres poemas de A rosa do povo, Drummond narra um episódio de violência urbana em que um disparo acidental entorna no chão a vida de um trabalhador humilde. Ao longo das oito estrofes, veem-se confrontados o trabalho reificado do entregador de leite, que se esquiva entre objetos confusos "na luta brava da cidade", e o do poeta, que, movido por "impulso de humana compreensão", supõe intenções onde só havia o ruído das garrafas abafado pelo sono dos homens. 
O poema progride da impessoalidade das legendas, na estrofe inicial, ao tiro em salvaguarda da propriedade ("Está salva a propriedade"), encerrando-se com a imagem da aurora, correlato objetivo da mescla entre sangue e leite no "ladrilho já sereno".

Esse final introduz uma ruptura lírica em relação ao clima narrativo predominante e de certo modo apazigua as tensões acumuladas ao longo do poema, dando dimensão cósmica à morte socialmente produzida.

Analisando o poema, Alexandre Pilati refere-se à aurora feita de leite e sangue como um clichê kitsch que atestaria a correspondência, no âmbito do trabalho poético, à reificação no trabalho do leiteiro. Explica Pilati (2009, p 126):

O recurso ao kitsch [...] de certa forma é uma referência à falta de saída para a própria literatura nos termos da lógica da reificação. Que código novo seria capaz de surgir para revigorar a referência literária ao quadro geral de reificação? A forma do comentário, assim, parece referir-se mais uma vez ao agastamento das possibilidades do sistema literário brasileiro. Este final realiza, pois, melancolicamente, a constatação de que a literatura, ou ao menos a lírica, estaria perdendo a sua possibilidade de representar a totalidade do país, de uma perspectiva progressista. Tudo seria já inexoravelmente mercadoria?

Ainda segundo o autor, tal fecho kitsch desempenharia papel crítico, servindo para assinalar a frustração histórica do poeta, que, a despeito da solidariedade, conhece de modo insuficiente seu "outro de classe".

Seria conveniente problematizar essa caracterização da aurora como clichê kitsch, sobretudo se levarmos em conta a reiteração da metáfora auroral não apenas em outros poemas de A rosa do povo, mas também em livros anteriores como Sentimento do mundo e Brejo das almas (cf. Pedrosa, 2010). Em “A noite dissolve os homens”, por exemplo, nos versos finais lê-se:

Havemos de amanhecer. O mundo se tinge com as tintas da antemanhã e o sangue que escorre é doce, de tão necessário para colorir tuas pálidas faces, aurora. 
A imagem tem longa tradição na retórica revolucionária, sinalizando uma espécie de momento inaugural, utópico, libertário. Drummond então a retoma e subverte, empregando-a diversas vezes de modo desiludido. No poema sobre o leiteiro, que encena uma morte sem heroísmo, triste caso de polícia, o tropo perde a aura esperançosa e já não expulsa a treva histórica. Nesses versos, além disso, o surgimento da imagem nada tem de arbitrário nem de abrupto (o que parece contradizer a ideia de um emprego imotivado, ornamental ou kitsch), sendo antes objetivamente motivado pelo encontro efetivo de leite e sangue.

Mas a passagem do tiro à aurora sugere mesmo um desvio sobre o qual conviria refletir. A vibração lírica final em um poema em que o tema da violência recebe abordagem crítica constituiria um desequilíbrio temático-expressivo? Haveria aí, em alguma medida, estetização da violência? A suposta beleza da imagem empana o gume da violência ou faz perder de vista a cidade que a produziu?

Como termo de comparação, evoquemos o "leite negro da aurora" (Schwarze Milch der Frühe) do poema "Fuga da morte" (Todesfuge), de Paul Celan (1920-1970). Escrito em 1951, seis anos após a publicação de A rosa do povo, tal poema aborda a violência genocida dos campos de concentração nazistas, bastante distinta da violência representada no poema drummondiano. Apesar disso, contudo, dada a coincidência no cruzamento entre leite e aurora, é lícito comparar o papel desempenhado pela metáfora auroral em relação às tensões de cada poema. Se em "Morte do leiteiro" a aurora rubriláctea concilia cores e líquidos, vida e morte, em "harmonia" cósmica (o enlace é amoroso e suave, em resposta à incompleta redenção da noite), em "Fuga da morte", a estranheza mortífera do "leite negro" (convertido em um interlocutor vivo com quem dialoga o sujeito plural do poema) nada concilia, antes se desdobra em novas oposições (Margarete e Sulamita, ouro e cinza, ar e cova), que aprofundam a tensão inicial.

De todo modo, aceitemos provisoriamente a sugestão de Pilati de que o fecho metafórico de "Morte do leiteiro" indica um limite de expressão para a solidariedade entre o poeta e o humilde entregador. É como se a linguagem resistisse a ultrapassar as fronteiras de classe, usando armas talvez inapropriadas para representar a violência resultante do consórcio entre trabalho e desigualdade.

Sem embargo, antes de especularmos sobre quais os eventuais limites na representação poética da violência urbana hoje, em que as fronteiras de classe se põem de 
outra maneira, passemos ao segundo grupo de tiros - e talvez a outra modalidade de desequilíbrio temático-expressivo.

Detenhamo-nos então, com um pouco mais de vagar, no poema "Tatuagem enigmática"13, de Duda Machado, publicado em Zil (1977). O poema trata de um crime cometido em um presídio carioca, criando nexos entre morte, civismo, erotismo, metalinguagem. Ele associa também o apuro construtivo concretista e a irreverência crítica da poesia marginal, o que se traduz formalmente pela combinação entre um procedimento modernista bastante utilizado pelos poetas marginais (a paródia ou aproveitamento da linguagem jornalística) e o criptograma, tão ao gosto dos experimentos visuais concretistas.

Eis o poema:

\author{
A LONGA VISITA AO PRESÍDIO \\ O GRANDE AMOR PELA GUANABARA \\ UMA COINCIDÊNCIA SINISTRA
}

\begin{abstract}
\begin{tabular}{ccc|c}
23 & $\mathrm{R}$ & 4 & ${ }^{\circ} \mathrm{C}$ \\
$\mathrm{I}$ & $\mathrm{I}$ & $\mathrm{GB}$ \\
65 & $\mathrm{O}$ &
\end{tabular}
A.

TATUAGEM ENIGMÁTICA NÃO É MAIS MISTÉRIO*

* O mistério da tatuagem está decifrado. Lendo-se verticalmente, vê-se a data de 23/1/65 - data do aniversário de Lilico - quando os dois se avistaram longamente no presídio. Em seguida, está a palavra Rio e, ao lado, o número 4. O traço vertical - que representa a letra I- de Iracema, está entre o 4 e as letras seguintes, unindo seu nome à sigla do 4 을 Centenário da Guanabara, prova de seu amor pela cidade. Três dos quatro tiros foram desferidos à queima-roupa junto ao ouvido direito em forma de triângulo, da mesma maneira Iracema, que cercou na tatuagem a letra $\mathbf{A}$, de Ana, seu nome de guerra.
\end{abstract}

(do livro Zil, 1977, recolhido em Crescente, 1990, p. 55)

"Tatuagem enigmática" parece dividir-se em três blocos: o primeiro, no terço superior da página, é composto por frases nominais, em letras maiúsculas. Logo abaixo, ao centro, uma espécie de fórmula ou mensagem em código, composta de letras maiúsculas, serifadas e sem serifa, números e sinais gráficos, alguns dos quais coloridos (três pontos vermelhos que se destacam do restante do texto, em preto), de sentido inapreensível à

\footnotetext{
${ }^{13}$ Adotado no índice do livro, esse título não aparece no poema, conquanto advenha de uma frase dele.
} 
primeira vista, e que constituem justamente o enigma tatuado. O criptograma, como é usual, lança mão da ambiguidade: certos sinais, como as barras verticais, podem ser percebidos aí tanto como números quanto como letras. Por fim, na parte inferior, lê-se uma frase com verbo (“Tatuagem enigmática não é mais mistério"), igualmente grafada em maiúsculas, a qual remete, por meio de asterisco, ao texto que ocupa o terço inferior da página. À diferença do restante do poema, esse texto final, em corpo reduzido, alterna maiúsculas e minúsculas e se apresenta como a nota de rodapé correspondente à frase que o antecede. A nota contém alguns termos destacados em negrito, designando os componentes do criptograma cujo sentido é finalmente elucidado.

Algumas observações gerais: a consideração do conjunto reforça a impressão de peça heteróclita, em que se misturam a abstração atemporal da fórmula e a carga factual do registro jornalístico com toque grotesco, sensacionalista. Assim, podem-se ler as frases iniciais como manchetes, a frase sob o criptograma como lead e a nota como reportagem, que fornece a chave decodificatória para o enigma visual.

As manchetes, com estrutura sintática semelhante (substantivo + adjetivo ou adjunto adnominal), relacionam crime e amor cívico, com um toque de suspense em torno da tal "coincidência sinistra". Nelas, o topônimo Guanabara (designação do Estado criado em 1960, após a fundação de Brasília, e que existiu até 1975, no território hoje correspondente ao município do Rio de Janeiro) de imediato situa o poema espacial e temporalmente, o que é ratificado pela menção ulterior à efeméride do IV Centenário da cidade, comemorado em $1965 .^{14}$

No entanto, aqui, distintamente do que ocorre em "Poema tirado de uma notícia de jornal", de Manuel Bandeira, o elemento factual acede ao poema em uma linguagem pouco transformada. Enquanto em Bandeira o dado contingente ganha generalidade graças ao hábil arranjo construtivo (assimetria entre as extremidades do poema e os versos centrais, regulares em termos silábicos, morfológicos e fônicos ${ }^{15}$ ), em "Tatuagem enigmática" isso parece depender da condensação do criptograma, que fixa a anedota sinistra suprimindo-lhe o contexto.

\footnotetext{
${ }^{14}$ A data mobilizou uma série de comemorações: torneio internacional de futebol no Maracanã, carnaval com os símbolos do IV Centenário, cartazes da Secretaria de Turismo com Pelé como garoto-propaganda, canções, filmes etc. O governador recém-eleito era Carlos Lacerda, que havia apoiado o golpe de 1964.

${ }^{15}$ Ver análise do poema feita por Arrigucci Jr. (1992).
} 
Ademais, o poema bandeiriano associa o descenso trágico de João Gostoso ao percurso entre dois espaços sociais conflitantes (Morro da Babilônia $\times$ Lagoa Rodrigo de Freitas), cria expectativas e suspensões em torno do estereótipo sobre as "alegrias do morro" e aturde pelo final abrupto e inesperado.

Já em Duda a tragédia ocorre em um espaço mais homogêneo e restrito, relacionando atores de extração socioeconômica aparentemente semelhante, cujo destino se mistura à história do Rio de Janeiro e a certa imagem do país (atentar para o brasileirismo dos nomes, sobretudo Iracema, a virgem dos lábios de mel, aqui convertida em amante puta e assassina), que enlaça ufanismo e violência, em sintonia com o espírito ditatorial de meados dos anos 1970.

No entanto, cumpre indagar qual o efeito desse jogo entre o plano prosaico-temporal da notícia e a abstração visual do criptograma. O suspense criado pela menção à “coincidência sinistra" e o mistério em torno da tatuagem são resolvidos pela notícia? O mistério é desvendado em um movimento que sacia a curiosidade do leitor e naturaliza o absurdo, acentuando o aspecto pitoresco/aberrante do homicídio como traço nacional? No lugar de um choque parecido com o que produz o desfecho de "Poema tirado de uma notícia de jornal”, não haveria nessa "Tatuagem enigmática” certo prazer pela consumação do jogo decodificatório? A charada não sufoca o homicídio, convertendo os tiros em mera chave léxica, mímica que o leitor logo adivinha? A violência é neutralizada pela estetização da cifra (como a história pela efeméride)? Ou o atrito entre a placidez do criptograma e o desconforto do contexto faz com que a tatuagem também funcione como uma espécie de sepultura?

Difícil é ajuizar o alcance crítico do poema. Sem embargo, talvez convenha examinar com um pouco mais de detalhe as ambiguidades que ele põe em campo. Primeiramente, no plano discursivo, há a menção ao duplo aniversário, de Lilico e da Guanabara. Aniversário que é de vida e de morte, do presidiário e também da cidade, cujos festejos recalcam o luto do regime democrático. Lilico, por seu turno, é criminoso (cumpre pena), mas também vítima, assassinado por Ana/Iracema, que o ama como ao Rio, e que “encripta" no próprio corpo o homicídio e seu nome "de guerra" (expressão ambivalente 
que designa o pseudônimo utilizado por prostitutas, associando amor e guerra ${ }^{16}$ ). Assim, ela se converte em "sepultura viva" por meio da tatuagem. ${ }^{17}$

Todas essas ambiguidades ou ambivalências são reforçadas pela associação entre o plano discursivo e o icônico, que utiliza procedimentos da poesia visual para compor uma imagem disfórica da cidade e do país (à diferença da criada pela poesia concreta, mesmo na etapa do "salto participante").

Mas o que reter desse excurso por poemas compostos fora do recorte temporal adotado na presente pesquisa e referidos a períodos de exceção, bastante distintos das condições vigentes no regime democrático em que, não obstante, o problema da violência perdura? Na poesia pós-1990, o recurso à metáfora e às conciliações líricas pode constituir alguma espécie de limite crítico para a representação da violência? Ele de alguma forma se relaciona a ambiguidades na identificação do poeta com os alvos da violência, não raramente distantes do lugar social por ele ocupado? O eventual apaziguamento das tensões ou a adesão contraditória ao ponto de vista da população pobre constituiriam critérios judicativos seguros para a avaliação estético-ideológica desses poemas?

E quanto ao uso de expedientes formais provenientes da tradição - como o criptograma e outros recursos gráficos ou a paródia jornalística -, de que maneira eles deslocam, se é que o fazem, as representações midiáticas, “espetacularizadas”, da violência?

Eis perguntas a considerar ao longo das análises seguintes. Contudo, antes de retornar aos poemas, convém situar um pouco melhor as pretensas novidades do vínculo estabelecido entre violência e cidade no contexto contemporâneo.

\footnotetext{
${ }^{16} \mathrm{O}$ sentido bélico é, contudo, ampliado nesses versos, aplicando-se não apenas à zona, mas também à cadeia e ao país.

${ }^{17} \mathrm{O}$ nexo entre pele, escrita e violência aparece também na seção final do livro À mão livre, de Armando Freitas Filho. A obra, publicada em 1979 com poemas escritos a partir de 1975, fecha-se com o poema "Pele", composto por sucessivos enxertos em um verbete de dicionário dedicado ao substantivo "pele". Tais enxertos especificam agressões e torturas que desfazem a pele como invólucro corporal, e a violência se efetiva pela invasão do próprio verbete por corpos textuais estranhos ao rol original de acepções. Ainda com relação à violência escritural, cumpre lembrar o valor de que se reveste a tatuagem - o "escrito sobre um corpo", para lembrar o título de Severo Sarduy - no imaginário neobarroco. Segundo Simon e Dantas (2011, p. 119), a tatuagem, "metáfora encenada na carne, cheia de conotações rituais e místicas que atestariam a radicalidade vanguardista de uma fusão escrita/vida", remeteria ao gozo sadomasoquista da ferida legível, ao desejo de substituir as marcas do tempo, impostas pela finitude orgânica, por relatos e símbolos de sentido inaferrável. Os autores, a propósito de um poema de Carlito Azevedo dos anos 1990, demonstram como a poesia atual se apropria dessa erótica textual neobarroca de modo fetichista, descartando sua carga transgressiva.
} 


\section{Mixofobia e a cidade-sequela}

Dentre as múltiplas hipóteses aventadas ao longo do tempo para explicar o surgimento das cidades, o comércio e a guerra aparecem de modo recorrente. Se para certos urbanistas, no entanto, é a guerra e não o comércio que está na origem dos centros urbanos $^{18}$, a verdade é que ela também diz respeito a seu futuro, ainda mais em tempos de privatização crescente dos espaços públicos e transformação do ambiente urbano em uma espécie de locus terrificus. O que não constitui surpresa da perspectiva de certa convenção retórica (para a qual locus amoenus é sempre o campo) representa, em verdade, uma inversão notável do processo de desenvolvimento que associava o perigo à natureza e aos sítios ermos, distantes das aglomerações urbanas (tradicionalmente percebidas como local seguro e acolhedor, aberto à diversidade).

Tal transformação remonta a fins do século XIX, ao fenômeno de expansão das cidades industriais e desemboca, grosso modo, no contexto pós-urbano das cidades globais, onde a velocidade parece ensejar um novo tipo de sedentarismo: o sedentarismo do transporte, a ditadura do movimento, que nos faz habitar não mais o espaço geográfico, e sim o tempo inerente ao deslocamento entre espaços permutáveis.

Segundo Virilio, tal situação derivaria, entre outras coisas, da corrida tecnológica imposta pela indústria bélica, a qual se alimenta da sensação de um estado de emergência permanente a que ele dá o nome de Guerra Pura ${ }^{19}$. O imperativo de velocidade daí decorrente degrada a ideia de viagem, reduz o mundo a um único lugar e, paradoxalmente, tende a nos "confinar na mobilidade", à medida que a mobilidade física vai pouco a pouco se aproximando da mobilidade eletrônica.

Esses espaços de trânsito e consumo, de circulação acelerada de bens e pessoas como os grandes centros comerciais, as vias expressas, os terminais intermodais de transporte e os novos complexos aeroportuários, que não se definem pela identidade de seus usuários, nem se integram aos lugares antigos, tampouco estratificam algum tipo de memória - são o que o antropólogo Marc Augé chamou de "não lugares", produto da

\footnotetext{
${ }^{18}$ Ver, por exemplo, o que afirma Paul Virilio a esse respeito: "O comércio surge depois da chegada da guerra a um lugar, depois do estado de sítio, da construção de um talude em torno de uma área inabitada etc. Ele não necessita da cidade - a cidade no sentido da sedentariedade, da mineralização de uma construção. O mercantilismo é até o oposto da sedentariedade: ele é uma pausa, uma trégua entre dois fluxos" (Virilio e Lotringer, 1984, p. 16).

19 "A perpetuação da guerra é o que chamo Guerra Pura, guerra que não é perpetuada por repetição, mas por preparação infinita. Só que essa preparação infinita, o advento da logística, também acarreta o não desenvolvimento da sociedade no sentido da sociedade civil." (Virilio e Lotringer, 1984, p. 90)
} 
supermodernidade, cujo arquétipo é o espaço do viajante. Esses "não lugares" se contraporiam aos lugares antropológicos por seu caráter dessocializante e por uma espécie de controle identitário supressivo, em que os consumidores desfrutam as alegrias do anonimato depois de terem sido rigorosamente cadastrados. Afirma Augé (2008, p. 102):

O espaço da supermodernidade é trabalhado por essa contradição: ele lida com indivíduos (clientes, passageiros, usuários, ouvintes), mas eles só são identificados, socializados e localizados (nome, profissão, local de nascimento, endereço) na entrada ou na saída.

Tal "anonimato controlado" parece contrariar o caráter público desses espaços, em que o acesso deveria ser franqueado a qualquer um, sem seleção prévia ${ }^{20}$.

Mesmo considerando a interveniência de outros fatores no processo de desterritorialização, e tendo em vista que a capacidade circulatória é economicamente regulada (o controle nos tempos de deslocamento e o acesso aos locais significativos, em termos de centralidade e acesso a bens e serviços, são distribuídos de modo desigual, com favorecimento das classes dominantes ${ }^{21}$ ), parece oportuno investigar de que maneira o pânico associado à vida nas cidades globais se abastece com frequência de um "imaginário bélico". As balas perdidas criam uma atmosfera de guerrilha, os altos muros dos shopping centers, dos prédios de escritórios e dos condomínios fechados seguem a lógica dos bunkers; a desfiguração do patrimônio arquitetônico, imposta pela voragem mercantil dos megaempreendimentos imobiliários, consagra a ruína sem bombardeio ${ }^{22}$; a blindagem dos carros de passeio evoca a solidez dos tanques... e assim por diante.

A estigmatização dos espaços públicos, vistos como fonte de crime e violência, e o consequente enclausuramento em espaços privados e socialmente homogêneos não apenas suspendem o potencial emancipatório da vida citadina (Stadtluft macht frei), mas também concorrem para agravar a sensação de insegurança generalizada.

Contudo, conforme nos adverte a antropóloga Teresa Caldeira (2009),

\footnotetext{
20 “Um espaço é público à medida que permite o acesso de homens e mulheres sem que precisem ser previamente selecionados. Nenhum passe é exigido, e não se registram entradas e saídas. Por isso, a presença num espaço público é anônima, e os que nele se encontram são estranhos uns aos outros, assim como são desconhecidos para os empregados da manutenção.” (Bauman, 2009, p. 69)

${ }^{21}$ A esse propósito, ver Villaça (1998).

${ }^{22}$ Mas os exemplos recentes de desalojamento forçado na região da chamada Cracolândia, no bairro da Luz, em São Paulo, ou da ocupação do Pinheirinho, em São José dos Campos, infelizmente me desmentem.
} 
aglomeração e densidade urbanas não necessariamente provocam violência, como querem muitos dos discursos antiurbanos. Nem mesmo as más condições urbanas e a pobreza podem ser claramente apontadas como causa da violência. Esta parece ter mais a ver com o funcionamento da Justiça e da polícia e com o desrespeito sistemático a alguns direitos dos cidadãos do que com qualquer variável de infraestrutura urbana. ${ }^{23}$

Ainda assim, a fim de controlar os fortes sentimentos de mixofobia (Bauman, 2009) decorrentes de uma visão equívoca sobre a gênese da violência, criam-se dispositivos arquitetônicos que, em vez de defender a cidade de adversários externos (papel outrora desempenhado por elementos como muralhas e fossos), servem para dividir e manter isolados os próprios habitantes - o que retroalimenta a mixofobia, criando um círculo vicioso. Por conseguinte, vemos se espalharem marcos de uma arquitetura "antimendigo", que retira das praças os bancos nos quais era possível se deitar, instala sobre as marquises canos que espirram água em intervalos regulares ou constrói ao longo dos muros estruturas pontiagudas ou declives calculados para impedir o sono nos desvãos e negar abrigo ao miserável, ao desgarrado. ${ }^{24}$

Se a hostilidade contra os pobres é velha ("Assomons les pauvres", já ironizava grotescamente Baudelaire), a novidade talvez se prenda ao fato de tais dispositivos não serem mais "acionados" apenas por comerciantes ou moradores de condomínios de luxo, mas pelos próprios poderes públicos, que já nem sequer se dão ao trabalho de sustentar um discurso hipócrita em favor dos desafortunados.

Uma tipologia dos espaços "expulsivos" nas cidades contemporâneas é o que nos oferece o arquiteto Steven Flusty, que os classifica em espaços “escorregadios” (que não

\footnotetext{
${ }^{23}$ Não se trata de subestimar os aspectos socioeconômicos na gênese do medo urbano, mas de enfocar o problema com base na violação dos direitos civis e individuais, menos legitimados que os direitos sociais e políticos no contexto do que Caldeira chama de "democracia disjuntiva". Ver sobretudo o capítulo 9 do livro Cidade de muros: crime, segregação e cidadania em São Paulo. Nele, a autora relaciona a oposição, já no início do regime democrático, aos defensores dos direitos humanos e a campanha pela introdução da pena de morte na Constituição brasileira ao "aumento do crime violento e do medo, e as tendências urbanas na direção da fortificação e de novos modos de segregação [...] " (Caldeira, 2003, p. 343).

${ }^{24} \mathrm{~A}$ imprensa noticia todos os dias iniciativas dessa natureza. Ver, à guisa de exemplo, matéria sobre reformas recentes na Praça da Sé, que substituíram os bancos por apoios glúteos e criaram fossos para impedir o acesso aos espelhos d'água em que a população de rua costumava se lavar. (Ferreira, 2007). Ainda sobre o desaparecimento dos bancos públicos, comenta o filósofo Thierry Paquot: "Le déshumanisation d'une societé commence comme cela, par la disparition d'une chose aussi banale qu'un banc public, signe elémentaire de l'hospitalité, degré zéro du 'vivre ensemble'. L'automobiliste pressé et le piéton affairé ne s'en aperçoivent pas, tout comme ils ignorent le parcours humiliant et semé d'embuches pour les personnes à mobilité réduite" (Paquot, 2006, p. 55). Voltaremos a essas questões no terceiro capítulo, dedicado ao tema do desabrigo.
} 
podem ser alcançados, por restrições de acesso), "escabrosos" (impróprios à ocupação confortável, como aqueles em que borrifadores d'água ou bordas inclinadas afugentam as pessoas) e "nervosos", aqueles sob vigilância perene, on-line full time (Flusty, 1997, p. 4852, apud Bauman, 2009, p. 42).

Fato é que, nessas configurações, o espaço público torna-se cada vez mais residual, ou seja, converte-se naquilo que "sobra" entre bolsões de espaço privado. Não obstante, mesmo entre os arquitetos, há quem se escore no fracasso das utopias arquitetônicas modernas (incapazes de cumprir as aspirações igualitárias que as norteavam) e proponha a superação desse estado de coisas não por uma crítica distanciada, que idealize a função integradora do âmbito público, mas pela aceitação do caráter desarticulado, fractal dessas cidades. É o caso do holandês Rem Koolhaas, o qual se referirá ao fruto da modernização como um "espaço-lixo", "aquilo que sobra depois que a modernização tiver seguido seu curso, ou melhor, o que se coagula enquanto a modernização está em curso: sua sequela” (Koolhaas, 2007, apud Wisnik, 2009, p. 258). Explica Koolhaas (2006, p. 359):

A cidade com que temos de nos arranjar hoje é mais ou menos formada de fragmentos de modernidade - como se as características abstrato-formais ou estilísticas às vezes sobrevivessem em estado puro, enquanto o programa urbano não saísse conforme o planejado. Mas eu não lamentaria esse fracasso: os estratos neomodernos que dele resultam, e que literalmente invalidam a cidade tradicional da mesma forma que anulam o projeto original de modernidade, nos oferecem novos temas de trabalho. Com eles, podemos pôr frente a frente as edificações desse período e os diferentes tipos de espaço - o que a doutrina pura do modernismo não permitia.

No entanto, além da segregação territorial da pobreza, do acesso desigual a espaços e serviços, da arquitetura paranoica, medusada pela ilusão de inexpugnabilidade, empenhada na bunkerização do espaço e na construção de dispositivos pan-ópticos e expulsivos, devemos ainda levar em conta, na gênese do medo urbano, fatores como a permanência, no regime democrático, da lógica militar que norteia as políticas públicas de segurança. Tal lógica hipertrofia a dimensão vigilante-repressivo-punitiva do Estado, orientando também a ação dos grupos parapoliciais de extermínio, cujo papel é decisivo na 
configuração do crime organizado em metrópoles como São Paulo e Rio de Janeiro. É em função dessa lógica comum que, sobretudo para os jovens infratores da periferia, desafiliados dos circuitos de legitimação social, mergulhados na vida loka, a polícia, como bem observa o etnógrafo Gabriel Feltran (2011, p. 78), "surge, nitidamente, compondo a experiência de quem se vê imerso no mundo do crime e não contrapondo-se a ela”.

A militarização da polícia é especialmente danosa por adotar como modelo situações de guerra, de defesa do território contra um inimigo externo, que pode ser liquidado, que não é cidadão. Lembra o jurista Túlio Vianna (2012) que, se nas Forças Armadas a morte é regra e a prisão, exceção, nas Forças de Segurança deveria ocorrer o contrário. Assim, ainda segundo o autor, embora a militarização não possa ser apontada como único fator causal, ela certamente desempenha importante papel no elevado número de homicídios provocados pela polícia. ${ }^{25}$

Nunca é demais insistir quanto ao fato de que essa militarização da vida, conforme asseveram Felipe Brito e Pedro Rocha de Oliveira, "não só protege como também opera um modelo de política urbana ao mesmo tempo empresariado e empresarial" em que a proteção vira mercadoria política e o combate à violência adquire "feição de guerra declarada contra os pobres" (Brito e Oliveira, 2013, p. 66). E é justamente nos momentos de crise da segurança pública - por exemplo, durante os ataques da facção criminosa Primeiro Comando da Capital (PCC), em São Paulo, em maio de 2006 - que essa situação se radicaliza e as formas ilegais de violência passam a ser encaradas com mais naturalidade. Explica Gabriel Feltran que, quanto mais a repressão se organiza, "mais politicamente orientada ela se torna", legitimando a ilegalidade como suplemento da ordem. Tal legitimação se fundamenta "no argumento, mais ou menos explícito, a depender da situação, de que seu oposto (a legitimação dos bandidos) seria ainda menos aceitável”. A violência ilegal torna-se, desse modo, "parte constitutiva das ações de definição dos critérios de repartição da legitimidade social e pública, e portanto da própria lei” (Feltran, 2011, p. 321-2).

\footnotetext{
${ }^{25}$ Com base em dados divulgados pelo jornal Folha de S.Paulo em julho de 2012, Vianna observa que, só em São Paulo, o número de mortos em confrontos com a polícia no período de 2006 a 2010 é quase nove vezes maior que o total de mortes de todas as polícias (exclusivamente civis) norte-americanas no mesmo período (segundo o FBI), diferença que também ressalta no índice de mortos pela polícia em cada 100 mil habitantes: 5,51 no Estado de São Paulo contra 0,63 nos EUA (Vianna, 2012). Assim, o jurista defende a desmilitarização e unificação das polícias, o que não apenas contribuiria para a diminuição da brutalidade (inerente à lógica do extermínio do inimigo, sendo que a função da polícia é garantir direitos do cidadão, mesmo que infrator), mas também representaria considerável economia para os cofres públicos, além de permitir uma progressão de carreira em que o policiamento investigativo seria feito por pessoas com experiência no policiamento ostensivo (hoje, os policiais militares, à medida que progridem, passam a executar trabalho administrativo/ burocrático, desperdiçando a experiência acumulada nas ruas).
} 
Embora a recente mobilização das ruas tenha chamado mais enfaticamente a atenção da sociedade para as arbitrariedades cometidas pela polícia (ainda que o gás e as balas de borracha disparados contra manifestantes em grandes avenidas das capitais brasileiras sejam formas brandas de repressão comparadas à violência corriqueira "nas quebradas"), fato é que tal legitimação da violência ilegal, além de disseminar o medo aprofundar o fosso da desigualdade, testemunha a continuidade do terror no estado democrático de direito, como observa Maria Rita Kehl (2013):

A tortura permanece no Brasil. Só que isso não sai na imprensa, porque quem poderia denunciar tem medo. São as mães dos meninos que estão na cadeia, são as mães dos mortos de maio de 2006. [...] Em maio de 2006, depois dos ataques do PCC, a polícia de São Paulo entrou numa ação de vingança. Em uma ou duas semanas, matou mais do que matou na ditadura militar. Foram mais de 400 jovens. Só que as mães têm medo de denunciar. Até hoje tem desaparecidos. A tortura continua, a impunidade da tortura continua e o medo de denunciar a tortura continua. Porque as polícias continuam militarizadas. E em alguns Estados, como em São Paulo, é interesse do governador que continue esse terror que a polícia espalha entre as classes baixas.

Conquanto atinja com muito maior intensidade as classes baixas, o terror engendra um imaginário de guerra que atravessa a sociedade de ponta a ponta, mobilizando estratégias de defesa que agravam ainda mais o problema, em um círculo vicioso em que o medo justifica a violência, que provoca mais medo.

Voltemo-nos então para esse imaginário de guerra, que é também uma força modeladora do espaço urbano, um componente da argamassa que ergue muros e estende vazios. O exame mais detido de seus elementos constituintes talvez lance luz sobre o ônus subjetivo (desagregação psíquica, paranoia adaptativa, fobias de toda sorte...) associado ao modelo privatista da cidade global.

Para tanto nos ocuparemos do exame desse imaginário em trabalhos recentes do poeta Ronald Polito. Analisaremos a seguir dois poemas do livro Terminal, publicado pelo autor em 2006, no qual referências bélicas aparecem. 


\title{
III. Desastre e evasão em Terminal, de Ronald Polito
}

Ronald Polito abre a seção "City Lights", de Terminal ${ }^{26}$, com dois poemas em que a paisagem urbana é representada de modo aterrador, como palco de catástrofes sem remissão possível. Comecemos pelo que surge em segundo lugar na sequência de textos que compõem a seção:

\author{
DEVASSA, DEVASTAÇÃO \\ Então é isto: \\ um digladiador do bunker ensimesmado \\ entre perigos de \\ guerra ou trégua, rolamentos de \\ dentes cuspindo ciscos com \\ aço, e disparos elétricos, que \\ escapa (como um tiro - direto) \\ para a rua sem saída.
}

Poeira preta empastelando

a pele. Cabelos. Gosma

que sobe e desce de

novo. A noite num perfil com

sangue, corpos cortando

corpos, um vinco a mais na expressividade do

supercílio. Dilatação dos domínios

da ruína, exponenciação

dos pedaços. Ou menos: cacos.

Ou nacos de carne.

E coices.

A lâmina do horizonte já não brilha.

Estanca mesmo o que escorria.

Silêncio com sirenas.

(Terminal, 2006, p. 15)

De imediato, destacam-se elementos do universo bélico (digladiador, bunker, tiro, sangue, mutilações, ruína, lâmina e sirenas), muitas vezes em associação paradoxal, já que

\footnotetext{
${ }^{26}$ Note-se, a propósito do título, a associação entre as ideias de morte (paciente terminal, doença terminal) e movimento (terminal de linhas, ponto de conexão/transmissão).
} 
o digladiador é ensimesmado, a guerra se iguala à trégua (ambas fontes de perigo), o escape é sem saída e o silêncio, com sirenas.

A destruição, porém, é meio indeterminada: ignoramos suas causas e mesmo seu alcance. A cidade não aparece descrita de modo concreto, nem por meio de seus marcos arquitetônicos nem pela ação de seus habitantes. Estes, aliás, são reduzidos a corpos cuja humanidade só se adivinha pelo sangue com que sujam o perfil da noite, a lâmina do horizonte. Mesmo a menção à rua (sem saída) pode ser interpretada em sentido metafórico, como imagem de bloqueio e paralisia, sem designar necessariamente a via pública urbana.

Aparentemente, então, tal poema parece retomar sem novidade alguns elementos da obra pregressa do autor, sobretudo aqueles ligados aos temas do despedaçamento e da ruína, presentes, por exemplo, em versos como “agora:/ foi impossível chegar inteiro/ [...] agora: melhor que tarde/ (e ainda é cedo)/ um quase/ meio de desterro/ um tudo aos pedaços/ a poeira descendo [...]", do poema "Menos que nada", ou "[...] os pedaços se afastam/ um ruído nulo/ o sol soldado no céu/ [...] os pedaços se afastam/ pensamento e poeira", de "Legião", ou ainda "Toma: este pedaço/ainda é teu corpo.", de "Rol" - todos exemplos retirados da coletânea Intervalos (1998). Nesses versos, o sentimento de desastre aflora quase sempre relacionado ao âmbito do corpo (frágil e blindado, vigilante e exausto) e à paisagem natural, elidindo assim a cidade como espaço físico construído e como conjunto de vínculos, comportamentos e ações que nele têm lugar.

Também em Terminal encontramos outros poemas em que a destruição decalca seu modelo das catástrofes da natureza (por exemplo, no poema "Sem apocalipse", que, parecendo lamentar a carência histórica "de técnicas eficazes/ de destruição não/ rescindível", evoca a potência de um tsunami "que/ vindo devaste e ao voltar/ desterre") ou da fíç̧ão científica (como em "Hiper-realidade", onde, a partir de certo ponto do progresso humano, descarta-se a eventual existência de outros mundos a destruir).

Em "Devassa, devastação", todavia, o nexo com a cidade acaba por se estabelecer por causa do título da seção a que o poema pertence, "City Lights" (possível alusão irônica ao filme homônimo de Chaplin, já que aqui as luzes sugerem antes o clarão das explosões), e da contiguidade com o poema "Vivência", examinado a seguir, no qual os perigos enfrentados pelo sujeito poético remetem concretamente ao entorno citadino, descrito em detalhes. De toda maneira, cumpre indagar se o potencial traumático das imagens bélicas 
presentes em "Devassa, devastação" não deriva justamente da presença meio espectral dessa cidade feita de aço, eletricidade, poeira, gosma e sangue.

No que se refere aos aspectos formais, destaca-se o uso reiterado de enjambements nas duas primeiras estrofes. Tal uso dissocia as unidades rítmicas das semânticas e posterga o completamento do sentido, mimetizando isomorficamente o deslizar do sujeito em área conflagrada. Em verdade, o autor retira efeito expressivo da alternância entre esse movimento e certas pausas bruscas criadas pela pontuação, pela interpolação de parênteses $^{27}$, pelo uso de frases curtas após períodos extensos, que se estendem por vários versos (principalmente na segunda estrofe) - reforçando o jogo entre guerra e trégua, fluxo e viscosidade ("pele empastelada", "gosma que sobe e desce”), hemorragia e coagulação ("Estanca mesmo o que escorria").

Talvez pudéssemos nos perguntar se a imagem final da "lâmina do horizonte" não aplaina de modo excessivo e pouco inusitado as tensões em jogo no poema. Ao contrário, por exemplo, da "faca só lâmina" cabralina, em que a realidade rebenta a imagem, aqui a imagem estabiliza a realidade. Ainda assim, o contraste entre fuga e imobilidade alcança efeito expressivo.

Em outra ocasião já me referi ao papel da imobilidade na poética de Polito (Weintraub, 1999), demonstrando como a paralisação do corpo adquire valor defensivo em situações de grande adversidade, marcadas pelo risco onipresente da morte. Procurei também demonstrar como, em vários poemas, essa imobilidade contamina a escrita (lacunar, descontínua, rasurada) e a própria paisagem natural, que se coagula ou fragmenta.

Além da imobilidade, contudo, a experiência urbana angustiante pode ativar outros tipos de defesa, conforme se vê no poema a seguir, que, no livro, antecede o que acabamos de comentar.

\section{VIVÊNCIA}

A. Testando articulações e peças, ligames, a máquina com nervos, pele e ossos retesados no elevador abaixo, agora, rumo aos exercícios

\footnotetext{
${ }^{27}$ Ver penúltimo verso da primeira estrofe. O tiro, contido pelo parêntese e pelo travessão, não pode ser "direto": a tentativa de escape é assim graficamente interrompida, antecipando a revelação de que a rua é "sem saída".
} 
de manutenção, conseguindo

ultrapassar mais um foco

de guerrilha na calçada, um

trapo de cão, bazares

do perímetro de uma esteira

repletos de objetos nos confins entre

o nada e o indiferençável, e já

treinando usar largos

passos ao saltar lagos de

ácido chorume, exemplares instigantes

de mutilações, farejando comida

deglutida por todos os

deuses, uma garrafa de

cachaça, dejeções, um bueiro sem tampa, um

entulho de demolição, deixar para trás, por fim,

um insinuante buquê de fios letais e

desencapados que

brotam da grama.

B. Depois do viaduto logo se avista, quase

oculta, sob a copa dos coqueiros,

a enseada e, adiante, a praia

que desvela aos poucos a

baía e, mais para a frente,

a grande pedra que cai

no mar. Caminhar

em direção ao rochedo

impelido pelo vento que vem

de dentro. Aos poucos poder perder

densidade, peso. E então esquecer tudo,

esquecer! E para abandonar de pronto as

exclamações. E sem nem ver

o tempo passar. Displicente,

amalgamar-se.

(Terminal, 2006, p. 14) 
O poema se divide em duas partes contrastantes: na primeira, descrevem-se os esforços de um corpo para caminhar pela cidade como quem se entrega a uma verdadeira corrida de obstáculos: ele deve saltar seres mutilados, dejeções, bueiros destampados, fios desencapados, enfim, precisa esquivar-se de toda sorte de ameaças.

Aqui, ao contrário do que ocorria em "Devassa, devastação", a cidade aflora nitidamente com suas calçadas, bueiros, entulhos e suas personagens: "guerrilheiros", cachorros, camelôs, pedintes, gente ferida, mutilada etc. Une as personagens a condição de pária, a distância social em relação ao sujeito poético, que vem de (e parte para) outro lugar. Para ele, a rua se afigura então como o horrível intervalo entre a segurança dos espaços privados (o prédio com elevador) e a visão do mar, inumano e apaziguador.

No entanto, assim como as personagens da rua são rebaixadas à condição de obstáculo, mesclando-se a elementos inanimados (entulho, fios letais, dejetos e restos de macumba) "nos confins entre o nada e o indiferençável", também o movimento vital do sujeito poético é reificado, reduzindo-se a "exercícios de manutenção" da "máquina com nervos" - o que ajuda a compreender melhor o que impele esse sujeito, talvez o receio de se igualar àqueles de quem pretendia se isolar.

Contudo, o cenário apocalíptico não suscita aparentemente nenhum tipo de reação emocional no corpo que o percorre, como se se limitasse a saltar as quadrículas de um jogo de amarelinha ou a fazer sua ginástica, seu cooper matinal, desviando-se habilmente dos horrores incorporados à rotina - o que o autor explora ironicamente. A ironia é reforçada por expressões como "bazares do perímetro de uma esteira", "exemplares instigantes de mutilações", "lagos de chorume" e "um insinuante buquê de fios letais" ${ }^{28}$, que se destacam pela precisão ridicularizadora, pela conversão da piedade em interesse ocasional (indiferença reativa?) ou ainda pela associação entre perigo e belezas naturais, como lagos e buquês. Ou melhor, os perigos do cenário urbano em desmanche são sarcasticamente representados nessas imagens lacustres ou florais, em oposição ao papel defensivo representado pela natureza (vento e mar) na segunda parte.

Para entender melhor o que se passa aqui, talvez fosse útil nos lembrarmos, como contraexemplo, do nexo entre caminhada e reflexão no gênero romântico da meditação ambulante. Em um conhecido ensaio sobre o poema "Louvação da tarde", de Mário de

\footnotetext{
${ }^{28} \mathrm{~A}$ flor aqui não se contrapõe à náusea, antes a evoca, em versão eletrificada.
} 
Andrade, Antonio Candido (1993) filia os versos do modernista a essa tradição andarilha, em que uma reflexão de cunho dissertativo é transformada em modo de sensibilidade durante uma caminhada pela natureza. O precursor do gênero, conforme explica Candido, seria Jean-Jacques Rousseau, com seus Devaneios do passeante solitário (Les rêveries du promeneur solitaire), série de meditações em prosa escritas entre 1776 e 1778, interrompidas pela morte do autor e publicadas postumamente.

Em contexto diverso, Alfonso Berardinelli também invoca Rousseau a propósito da comparação entre as visões de cidade na poesia de Charles Baudelaire e Walt Whitman. Segundo o crítico italiano, em Baudelaire, a conversão do promeneur em flâneur implica não apenas uma subversão do otimismo do filósofo suíço (a positividade de seu bon sauvage), mas também de sua teoria da imaginação, apoiada no binômio solidão-natureza. A solidão, em Baudelaire

necessita banhar-se na multidão para perceber a si mesma e, assim, em lugar da mãe Natureza, temos a mãe Cidade, uma mãe prostituta, cuja beleza é sinistra e fria, a beleza de uma viúva desconhecida, cujo Eros carregado de promessas narcóticas só pode reluzir numa rua apinhada e barulhenta. (Berardinelli, 2007, p. 145)

Lugar de irredutível estranhamento, tal cidade opõe-se à Natureza, ao contrário do que ocorre em Whitman, herdeiro entusiasmado de Rousseau, para quem a cidade é um desenvolvimento daquela Natureza que se dissolve na realidade egótica, planetária e cósmica.

Em "Vivência", porém, não há traço do otimismo moral e social de Whitman, tampouco na caminhada aí descrita subsiste qualquer traço meditativo, já que a paranoia susta o pensamento. No entanto, a função escapista desempenhada pela natureza, sobre a qual nos debruçaremos, parece guardar traços daquele ideal rousseauniano...

No que concerne à construção do poema, mais uma vez destaca-se o recurso sistemático a enjambements, inter e intraestróficos, que mimetizam o pula-pula dessa "amarelinha do fim do mundo", deslocando artigos, preposições e conectivos para a extremidade direita dos versos e obrigando o leitor a saltar para o verso seguinte em busca do complemento sintagmático. 
As seis estrofes da primeira parte compõem um longo e único período formado por orações subordinadas reduzidas de gerúndio (testando, conseguindo, treinando, farejando) que se encerra com o "deixar para trás...", o qual introduz o derradeiro elemento da lista de obstáculos e prepara a entrada em outro espaço, marcado por outra disposição anímica.

Após tantas e tão fatigantes esquivas, a imagem do buquê insinuante e mortífero antes do ponto final cria uma espécie de suspensão, um alívio incipiente, que só se consuma na segunda parte. Nela, depois de sair do viaduto, o caminhante avista o mar, avança "em direção ao rochedo/ impelido pelo vento que vem/ de dentro" e termina por se fundir à paisagem.

Com base na associação entre processos caminhatórios e figuras de estilo proposta por Jean-François Augoyard e retomada por Michel de Certeau (1994, p. 181), poderíamos dizer que, na parte $A$, o deslocamento aos saltos remete a um tropo ambulatório equivalente ao assíndeto, devido à fragmentação do espaço e à elisão dos lugares conjuntivos, ao passo que, na parte $B$, a função totalizante desempenhada pelo mar sugere a sinédoque, em que um elemento espacial amplificado substitui o conjunto. Enquanto em $A$ tudo é medo e vigilância, pois a menor distração pode ser fatal, em $B$, há abandono e esquecimento de si, retorno à unidade, sentimento oceânico ${ }^{29}$. O ritmo também muda: menos entrecortado e sôfrego, tendendo a um relaxamento depois da ginástica pânica.

Somente agora se revelam a direção e o sentido da caminhada: para fora da cidade, do tempo, da humanidade; em direção ao mar, rumo ao amálgama. Revela-se também o que move o caminhante (o "vento que vem de dentro"), que não suportou a mediação dos obstáculos, preferindo a rota da evasão, em uma espécie de "vou-me-emborismo" regressivo. Que pensar, porém, dessa "vivência" da cidade na qual o encontro com as pessoas e os ambientes humanos, precários e degradados, aparece como prelúdio ao desejo de fusão com a paisagem?

Não se trata de aqui de uma condenação a priori do lírico, como se o real só pudesse emergir por intermédio do choque e do grotesco, nem de subestimar o valor expressivo dos movimentos de retirada e solipsismo como testemunho e recusa da miséria mundana. Ao contrário, em muitos casos, são justamente esses movimentos que propiciam algum descolamento em face da repetição anestesiante das brutalidades do “mundo cão". A

\footnotetext{
${ }^{29}$ No sentido freudiano mesmo, de volta à plenitude indiferenciada e perda dos limites do Eu, como ocorre em certas experiências místicas e religiosas (Freud, 1976).
} 
saída lírica-onírica e o recurso à natureza não são, portanto, um problema em si: é preciso considerar seu funcionamento em diferentes contextos. Se qualificamos de regressivo o fugere urbem em jogo aqui, é por distinguir no contraponto que ele cria uma função ostensivamente apaziguadora das tensões acumuladas na primeira parte da composição.

Cabe aqui um pequeno comentário sobre o título do poema, "Vivência", que muito provavelmente remete à distinção benjaminiana entre vivência (Erlebnis) e experiência (Erfahrung). Apesar da ressalva à moda Benjamin, mencionada na apresentação, penso que nesse caso há mesmo um empréstimo terminológico, feito pelo próprio Polito, que é necessário explicitar. A vivência, na teoria estética de Walter Benjamin, se oferece como sucedâneo da experiência, a qual é atrofiada na arte pós-aurática. Nos tempos da reprodutibilidade técnica, diante de obras destinadas ao consumo massificado, o espectador já não pode captar nenhum vestígio do fazer artístico, restando-lhe somente a "vivência", que, na cidade moderna, corresponde ao exercício ininterrupto de interceptação dos choques do homem moderno. Andando em meio à multidão, o transeunte é forçado a permanecer atento para proteger-se dos choques de maneira similar ao operário que, na linha de montagem, deve adequar seu ritmo ao da máquina, que dele exige, a cada minuto, respostas idênticas e estereotipadas. Assim, a "vivência do choque sentida pelo transeunte na multidão corresponde à vivência do operário com a máquina” (Benjamin, 1989, p. 126). Ambos se defendem dos choques, porém ao custo de um comportamento reflexo.

No entanto, na poesia de Baudelaire, objeto das considerações de Benjamin, a defesa mobilizada pelo choque não implica retraimento do sujeito ou saídas de tipo metafísico - o que tem a ver com a objetividade do lirismo que o move, mas também com a intensidade dos choques nas condições urbanas nas quais o poeta viveu (possivelmente menos ameaçadoras que o cenário anômico descrito no poema de Polito).

Em Terminal, o referido impulso de fusão/evasão vai-se manifestar em vários outros poemas, muitas vezes sob a forma de uma nostalgia do absoluto, do zero, do nirvana (o prazer do aniquilamento, que Freud relacionou à pulsão de morte), da não tensão: “a ideia obsedante/ de um inalcançável/ zero/ qualquer" ("Sem apocalipse”); "Um atrativo zero absoluto" ("Um nirvana"); "Todos os números reconduzidos à/ unidade, os planos e/ linhas, ao/ ponto" ("Plano de investigação"). 
Nessa busca metafísica, com frequência, o "pré-mundo" - "esse/ vácuo,/ filtro de passagem/ para qualquer/ estado da matéria," (versos do poema "Prova", também incluído em Terminal) - iguala-se à "pós-catástrofe", assim como o silêncio equivale à "palavra total”; a dissolução, à integração. Difícil é ficar neste mundo, suportar os limites da matéria, o fardo do relativo, sem ascender ao plano cósmico (como nos mundos reunidos na seção "Gabinete") nem descer ao infra-humano (como ocorre no bestiário da seção "Minizoo"). ${ }^{30}$

De todo modo, insisto mais uma vez quanto ao fato de que essa atitude de deserção do real está relacionada à intensificação do atrito e das tensões inerentes à vida citadina, em momentos de desordem social e deterioração dos espaços públicos.

\section{Bonvicino e a pane do alvorecer}

Outro autor em cuja obra encontramos sinais claros do medo provocado pelo ambiente urbano é Régis Bonvicino. Por se tratar de um poeta em atividade desde meados dos anos 1970, sua obra permite flagrar mudanças importantes no tratamento das angústias citadinas.

Sobre isso gostaria de lembrar o comentário de Vinícius Dantas, em um artigo de 1986, em que ele efetua um balanço da poesia dos anos 80. Ao analisar poemas de Sósia da cópia, o crítico chamava a atenção para o desencontro entre a matéria dos versos e o padrão formal que a modelava. Segundo ele, esse padrão, constituído por meio do convívio com as convenções vanguardistas, com o construtivismo concretista, acabava por recalcar a experiência exasperada da cidade. Afirma Dantas (1986, p. 43):

[...] a experiência pessoal do poeta pretende ir numa direção que não é autorizada por suas formas. Por um desses paradoxos do subdesenvolvimento, a poesia concreta tanto se assumiu como poesia da linguagem que se esqueceu de que era poesia do espaço urbanoindustrial. Régis é fruto deste paradoxo, embora seu impulso seja desesperado, dilacerado, autodestrutivo, em suma, maduramente urbano, ao contrário das idealizações concretistas; seu tratamento

\footnotetext{
${ }^{30}$ No artigo "O boi e o marciano", Bento Prado Jr. também associa o olhar cósmico e o infra-humano pela análise de dois poemas drummondianos: "Um boi vê os homens" e "Science fiction". No entanto, tais perspectivas não são mobilizadas metafisicamente, como em Polito, mas como exercícios de heterogenia do olhar que nos reconduzem aos limites da humana condição. Afirma Prado Jr. (2000, p. 222): "O marciano e o boi constituem-se como parâmetros simbólicos para a circunscrição da experiência humana. Mas nenhuma Metafísica vem aqui dar força ontológica ao que precede ou ultrapassa o homem, defini-lo com a falha no coração do diamante. [...] O segredo da dialética de Drummond é confirmar assim, de fora, o que estava dado desde o início na estreiteza da experiência subjetiva”.
} 
poético, porém, não pensa seu impulso, não o resolve, pois ele não encontra no concretismo as formas para materializá-lo.

Tal conflito entre impulso e tratamento, que configura um desequilíbrio temático-expressivo, fica bastante marcado, prossegue o crítico, principalmente pelo fato de que, nos poemas em questão, a realidade aparece em estado bruto, pois muitas vezes a intervenção do poeta é tolhida pelo "artesanato do verso contido", detendo-se nas "marcas técnicas do corte, do silêncio, da elipse”. E conclui:

Literal, a poesia de Régis acaba não sintonizando o seu sentimento básico: o sofrimento paulistanamente acuado, que pede reelaboração. Os poemas não são sofridos formalmente [...] porque o seu conceito de poema, impregnado de uma estranha modalidade de purismo, sufoca o mero registro - sem dramatizações, o poema alude a referências soltas e dispersas aparentemente purificadas de contexto. (Dantas, 1986, p. 43)

Na obra posterior desse poeta, contudo, ocorre um progressivo afastamento da lição concretista paralelamente à aproximação da language poetry norte-americana. Com isso, apesar da permanência das elipses e dos cortes, aquele "purismo" dos livros iniciais vai sendo posto de lado, enquanto as marcas contextuais aos poucos ressurgem.

Quase vinte anos mais tarde, tratando dos poemas de Remorso do Cosmos (2003), o crítico Alcir Pécora insistirá quanto ao fato de que à construção antidiscursiva em Régis não corresponde

[...] nenhum tédio pelos acontecimentos históricos. Ao contrário, o alarme da língua é também uma estridência do mundo. São referidos, por exemplo, o assassinato de um manifestante antiglobalização, vazamentos de petróleo, grandes corporações etc. A estridência é, portanto, política, e produz ressonâncias por todo o livro, mesmo em écfrases de movimentos rápidos e circunstâncias ínfimas [...]. (Pécora, 2004, p. 416) 
Assim, no que concerne à questão das figurações poéticas da cidade, principalmente naquelas voltadas para o problema da insegurança, a poesia de Bonvicino é propícia à discussão que vimos empreendendo. Nela se cruzam aqueles procedimentos desrealizantes, de esquiva ao real, que marcaram boa parte da produção poética dos anos 1980 e a crispação da urbe contemporânea, marcada pela destituição dos espaços públicos.

Para melhor compreender como isso se dá na prática, examinemos o poema “031197”, de Céu-eclipse (1999), livro em que há grande número de textos ocupados com o problema da moradia, a vida dos sem-teto, os dispositivos antimendigo etc.

031197

Eu também moro nas ruas. Uma ponta de cigarro na orelha e um cinzeiro - na mão. "Você não parece morar nas ruas". Um caco de dente na boca. Naquele instante, edifícios saqueavam sombras, insones, parindo cobras. Ele poderia subitamente ter sacado a faca, na calçada, disseram. Há margens debruadas de luzes. Edifícios cúbicos movendo-se sob arcadas de samaúmas. Esquinas defuntas? E, sob o arco, down town, lâmpadas inchadas medindo o horizonte. Correm vozes em desordem, mudas e um guincho talvez de guaxanim. De tarde, corvos latindo nas árvores e cacto abrupto da casa. Estradas guiando noites. Quase ao lado do Johnnie's, Coffee Shop, com seu leve jogo de luzes. Paredes não se encolhiam como sono. Acqua \& branco. Alba imóvel dentro do quarto. ${ }^{31}$

(Céu-eclipse, 1999, p. 65)

O poema, cujo título é uma data, sugere à primeira vista as páginas de um diário. Distinguem-se dois planos. Um deles é o de diálogo entre, digamos, um narrador (o relator do "diário"?) e uma segunda pessoa, possivelmente um mendigo, com quem ele se defronta. Há uma única fala em discurso direto - "Você não parece morar nas ruas" -, cujo emissor não é fácil identificar à primeira leitura e que pode se referir tanto a um pensamento como a uma frase efetivamente proferida. No segundo caso, tampouco sabemos se tal fala efetiva é dirigida ao narrador pelo homem de rua ou o contrário. De

\footnotetext{
${ }^{31} \mathrm{Na}$ edição princeps os versos são hifenizados. Posteriormente o poeta recolheu toda a sua obra poética no volume Até agora (São Paulo: Imprensa Oficial, 2010). Nessa coletânea mais recente, o poema aparece na página 202 com ligeiras alterações nas quebras de verso e sem hifenização, conforme reproduzido aqui.
} 
todo modo, esse primeiro plano do encontro, real ou imaginado, é definido por um lugar específico (a calçada) e um momento pontual (justamente o instante do encontro). Em um segundo plano, que se dilata em termos espaçotemporais, temos a descrição de um cenário que vai sendo progressivamente contaminado pela carga de conflitos latentes naquele contato entre dois estranhos.

De imediato, chama a atenção o advérbio "também" no primeiro verso. Não sabemos se ele remete a outra ação (“eu trabalho e também moro nas ruas") ou à afirmação de uma semelhança com o interlocutor homeless, uma parceria na exclusão ("como você, eu também moro nas ruas"). Essa segunda possibilidade é confirmada pelo questionamento "Você não parece morar nas ruas", que justamente coloca em dúvida a autenticidade daquele destino comum, o que a referência final ao quarto vem confirmar. Outra possibilidade seria supor que o "morar nas ruas" inicial se referiria ao desabrigo em sentido figurado, psíquico, à falta de lugar ou de acolhimento mesmo na presença de teto e paredes. A tomar por convincente tal hipótese, a frase entre aspas tanto poderia nem ter sido dita pelo "sem-teto" concreto, mas apenas imaginada por alguém que, diante dele, experimenta um misto de identificação e medo.

Da boca do suposto "sem-teto", a descrição faz emergir "uma ponta de cigarro" (cujas cinzas serão guardadas no "cinzeiro na mão") e um caco de dente, que se liga a uma cadeia de significantes da qual participam igualmente a faca e o cacto, imagens pertencentes ao universo do precário e do agressivo.

Há também desequilíbrio entre os dois planos. O primeiro resume-se a duas ou três passagens:

Eu também moro nas ruas

"Você não parece morar nas ruas"

Ele poderia ter subitamente sacado a faca, na calçada, disseram.

A situação é, pois, de confronto direto, com risco de morte, roubo ou outra agressão qualquer. $\mathrm{O}$ engenhoso no poema é que essa descrição sumária do conflito entre o "narrador", digamos, e o mendigo/bandido, vai-se espelhando e potencializando no segundo plano. Assim, a faca, que "ele podia ter sacado", ecoa nos "edifícios que saqueavam sombras", o risco de morte transfere-se para as "esquinas defuntas" e se projeta 
nos corvos à Edgar Allan Poe, latindo (em vez de crocitar) seus augúrios de "nunca mais", quem sabe. A adversidade do cenário se faz presente ainda na casa com seu cacto abrupto, nas cobras paridas.

A descrição que se inicia no espaço aberto da rua desloca-se progressivamente para o espaço fechado de um quarto cujas paredes não se encolhem como sono, conduzindo a uma paralisia do amanhecer.

Essa "alba imóvel" do final reveste-se de especial significação em um poema no qual o fluxo de deslizamentos metonímicos é vertiginoso. O próprio limite entre natureza (cobras, corvos, samaúmas...) e arquitetura quase se esbate em um cenário onde prédios movem-se, lâmpadas incham, estradas guiam. No plano animal, cobras nascem de edifícios; guaxinins viram guaxanins; corvos latem. Em sentido contrário a toda essa movimentação, a luz coagula-se, o tempo para. A tensão entre o pesadelo, palco de contínuas metamorfoses, e a insônia (que endurece a luz), o jogo entre mobilidade e imobilidade, entre "acqua" e "branco," culmina na imagem final da alba.

Tal imagem, bem como a cadeia de associações que nela desemboca, parece investida da tensão gerada no encontro com o estranho na via pública. Por outro lado, a imagem do nascente visto de um espaço confinado, em um livro em que os motivos do sol e da luz aparecem de modo recorrente, contraria os valores de mudança e renovação tradicionalmente associados à aurora, conforme já mencionamos a propósito da poesia drummondiana.

Certa indeterminação geográfica também chama a atenção do leitor. À primeira vista, tudo se passaria em uma cidade estrangeira, possivelmente uma cidade norte-americana, planejada para banir ou enclausurar a pobreza, como sugerem expressões em inglês como downtown (cuja grafia é segmentada) e "Johnnie's Coffee Shop". Entretanto, a referência às samaúmas, por exemplo, espécie nativa da América do Sul e da África, produz dúvida a esse respeito - o que talvez expresse o desejo de estender o alcance da cena, liberando-a do enquadre localista.

Essa oscilação entre referências locais e internacionais, aliás, atravessa vários poemas do livro, em que se misturam cenários paulistanos (com alusões pormenorizadas a ruas e bairros específicos) e notações de cidades como Los Angeles, Nova York, San Francisco. O próprio poeta se apresenta, não apenas nos poemas, mas também nas notas 
que os acompanham, ${ }^{32}$ como partidário da Weltliteratur, em contato com monumentos do modernismo autóctone - entre eles João Cabral de Melo Neto (cuja voz, captada por meio de um telefonema, inspira o poema "Voz"), Lúcio Costa e Tarsila do Amaral - e com criadores estrangeiros, a exemplo de Robert Creeley e Douglas Messerli.

Especificamente no caso de 031197, esse desejo de inscrição na ordem mundial leva a uma espécie de internacionalização da miséria que, quanto mais descolada das coordenadas nacionais, mais se torna sígnica, hipermidiática, proliferante. ${ }^{33}$ Pensando nessa internacionalização da miséria paralelamente ao diálogo com os ícones modernistas, é como se a realidade brasileira só pudesse aparecer parcialmente, filtrada pela imagem de seus artistas mais representativos, aos quais o poeta deseja se associar.

A despeito da indeterminação geográfica e da articulação fluida entre as imagens (sobretudo na descrição meio onírica do segundo plano), resta perguntar como esse trânsito para o âmbito privado, representado aqui pelo quarto (um quarto de hotel em uma cidade estrangeira?) relaciona-se às tensões inerentes ao encontro com que o poema se inicia.

Certamente estamos diante de um poema em que o problema da insegurança se articula com o do desabrigo, tema do terceiro capítulo, em que serão analisados outros poemas de Régis sobre moradores de rua. Aqui, no entanto, interessa acompanhar as vicissitudes desse potencial de violência que a rua implica.

Como tentamos sugerir, em comparação à obra inicial de Régis, em que a figuração dos conflitos urbanos era tolhida por uma poética avessa à mediação subjetiva e à "impureza" formal, nesse poema o contexto não está totalmente elidido: a situação de ameaça nascida do encontro com o pobre aparece com clareza. Mas o que a multiplicação imagética e a passagem para a intimidade do espaço fechado fazem com os sinais desse encontro ameaçador à medida que o poema caminha? O sentimento de estranheza, estribado em imagens concretas de precariedade, aos poucos parece ceder lugar a uma estranheza mais abstrata, em que o movimento das "vozes em desordem" é ao mesmo tempo transmutado e emudecido pelo debrum de luzes, pelas arcadas vegetais e pela

\footnotetext{
${ }^{32}$ Sobre o papel das notas na poesia de Bonvicino, leia-se "A angústia da insuficiência”, do crítico português Abel Barros Baptista. Nesse artigo, escrito como resenha do livro Céu-eclipse, o autor destaca a função controladora exercida pelas notas, que pretendem repor o vínculo referencial em uma poética cuja ambição seria dele prescindir. Afirma o crítico: "Encontramos aqui o que poderíamos chamar uma angústia da insuficiência. Adotando uma poética da concisão e da elipse, Régis Bonvicino só pôde ser levado àquelas notas pelo receio de que algo tenha ficado por dizer, mais radicalmente, pelo receio de que o poema seja insuficiente para dizer o que deve ser dito e que, no caso, é fundamentalmente isto: que o poeta adotou uma poética da concisão e da elipse. Assim, a nota é afinal o discurso alternativo que torna inteligível, não o poema, mas a opção poética do autor, mostrando que, a partir daquela matéria-prima, poderia fazer outra poesia, não se desse o caso de querer fazer essa!" (Barros Baptista, 1999).

${ }^{33}$ Devo a Iumna Simon as sugestões sobre a internacionalização da miséria.
} 
deslocada fauna, composta por cobras, corvos e "guaxanins". Se a cidade, de certa maneira, se fantasmagoriza, o que acontece com o desconforto diante dos estranhos que ela aproxima? E o que subsiste da faca, dos cacos, dos guinchos e dos latidos na imobilidade da alba privada?

Estaríamos diante de um efeito similar ao encontrado em "Devassa, devastação", em que a imagem final parece estabilizar as tensões do poema? Algo do pânico inicial, ligado ao brilho da faca não sacada, perdura no branco do alvorecer em pane?

O quarto aqui, ao que tudo indica, não desempenha a função de refúgio ou anteparo contra os perigos (luzes, guinchos, facas, bichos) da rua. Em verdade, esse quarto, onde não há escuro nem sono, parece remeter ao princípio do poema, já que nele perdura a perturbação dos espaços abertos, desprotegidos. Assim é que "Eu também moro nas ruas" sugere uma situação de desabrigo psíquico na qual o sentir-se em casa passa a ser uma impossibilidade mesmo quando não se tem de dormir ao relento.

\section{Cadáveres-fantoches em Aleijão, de Eduardo Sterzi}

Se em "Vivência", de Ronald Polito, e "031197”, de Régis Bonvicino, lidamos com situações de conflito potencial, em que a ameaça da violência, embora mobilizando reações defensivas, não se presentifica, examinaremos agora um poema de Eduardo Sterzi em que isso ocorre, um poema sobre um crime em ato, no qual a imaginação se desata a partir de um delito em curso. Trata-se do poema "Relâmpago", de Aleijão (2009), livro em que o tema da violência não é apenas um entre outros, constituindo antes o centro de imantação da obra. Tal tema é explorado em seus aspectos rituais e iniciáticos, em seu enraizamento familiar (com a presença obsedante da figura paterna e "sanguinária"), no âmbito da própria criação poética (em que a "filiação" também implica certo temor à castração) e, sobretudo, em uma experiência atroz da cidade.

O cruzamento entre algumas dessas modalidades de violência aparece de modo exemplar no primeiro poema da segunda seção do livro, "Coágulo", intitulado "Casa de detenção" (p. 19). Nele, a sensação de encarceramento enlaça a cidade natal do autor, Porto Alegre, as festas de família, embates adiados, revólveres sufocados, a própria escrita ("Fuga é sintaxe") e, em destaque no centro do poema, as grades do "Nome do pai" ("Como 
escapar ao cárcere/ do nome?”), avatar da lei. Nome “aleijado” em variações (Stenzi, Stronzo, Stretto, Estêncil, Stereo, Estéril, Esterco, entre as muitas que compõem o poema "Personagens", p. 57) que o libertam do cárcere da linhagem, associando-o a múltiplas identidades (o suicida, o corno, o triste, o doente/anão/aidético, o retardado, o perdedor de prêmios, o que não consegue mais escrever, o virgem, o impotente, o fracassado), na maior parte dos casos, resistentes à expectativa de reconhecimento social ou êxito individual ("os poetas são todos uns merdas/ [...] / matá-los seria perfeito", lê-se em "Poetas", p. 62). Tais identidades deceptivas reverberam no plano estético/metalinguístico, em que a criação incorpora o malogro e a "criatura" carrega consigo sempre algo de "golem", de inacabado ("Bem-vindo, aleijão:// à minha/ imagem// foste feito", lê-se no poema de abertura, p. 9), um defeito de nascença que funciona como amuleto e antídoto contra a "perfeição" furiosa do pai. $^{34}$

A violência oriunda das relações com a figura paterna (“escondem-se/ sanguinárias,/ as/ mãos/ de meu pai", em "Para fora d'água", p. 23; "saturno degusta/ seus filhos", em “O escrevente", p. 47) irradia-se para as demais relações familiares (como atestam o "embate de abraços" em "Irmãos [, ou Magma]",35, p. 24 e a terrível "rinha de mães", no poema “Teatro", p. 83) e também se encarna nas imagens recorrentes de incêndios, fogos, afogamentos, dentes, facas, canivetes, arpões, anzóis etc.

No tocante à expressão desse problema no âmbito das filiações literárias e da "angústia da influência", vale notar que ela se dá menos no campo do diálogo explícito, como ocorre em "Retratos", p. 52, paródia de conhecidos versos de Drummond, que no contrabando mais afetivo e inconsciente, conforme se vê no poema "A barca", p. 28: "Incendiou-se a barca/ que nos levava ao continente. Dormíamos/ em nossas cabines: a família/ toda morreu.// [...] // No cais,/ à nossa espera,/ ninguém: ninguém/ deu por nossa falta;/ ninguém nos reconheceu" - em cujos versos por mim grifados distingo o eco do poema "Remate", igualmente de Drummond (não por acaso outro poeta fortemente assombrado pela imago paterna, que retoma nesse poema, sem anelo de reconciliação, a

\footnotetext{
${ }^{34}$ Interpretando psicanaliticamente o ritual judaico da circuncisão, Jean Laplanche (1988) observa que o fato de o pai da criança entregá-la ao avô simboliza uma espécie de oferenda simbólica em que, para aplacar a ira do próprio pai pelo fato de ter procriado/acedido à potência, o filho oferece o fruto de sua "transgressão" para uma castração simbólica, refazendo o vínculo entre os homens do grupo. Parece-me que o "aleijamento" em Sterzi, mutatis mutandi, desempenha função análoga, simbolizando uma violência (auto)infligida ao filho, que, ao mesmo tempo, distingue-o do primitivo "pai/chefe da horda", emblema da potência sem freio ou mácula, e o vincula a ele, pelo emprego da força.

${ }^{35}$ Que retoma o poema "Irmão, irmãos", do Boitempo (1968) drummondiano.
} 
parábola bíblica do filho pródigo), de Lição de coisas (1962): "Ninguém recrimina/ ou perdoa,/ ninguém recebe./ Deixa de haver o havido/ na ausência de fidelidade/ e traição".

Como se pode verificar, o exame do tema da violência na poesia de Sterzi demanda uma consideração bastante detida desses cruzamentos entre família, literatura e cidade. Porém, tendo em vista nosso propósito aqui, fecharemos nosso foco sobre a seção "Na treva", a terceira e mais longa do livro Aleijão, em que o vínculo entre violência e cidade aparece com força em poemas sobre o esvaziamento compulsório das ruas ("Na marra", p. 78), resgate de sequestrados (“As armas [ou Também o sabes]”, p. 86), espancamento “Jogo", p. 98), entre outros motivos.

A violência que fornece matéria aos poemas dessa seção assume formas as mais extremadas, como se pode ver pela profusão de cadáveres espalhados pelos versos. Cadáveres garimpados sob o asfalto da avenida ("Forçando a carapaça/ de asfalto e paralisia, lavra/ de cadáveres, vulcão/ dormido", em "Na Paulista”, p. 77), cadáveres precoces para consumo do lixo ("Desde criança/ adestrado/ na prática/ do sumiço/ Desde carniça/ afeiçoado/ ao beijo/ do abutre/ Desmemoriado/ de ubre/ [...] /Ninguém/ me aplaude/ ou reclama/ meu corpo/ Com licença/ estou morto", em "Acidente", p. 84), mortos teatrais ("[...] na balsa dos mortos/ ensaiamos nosso moto-/ perpétuo o teatro do cães/ no asfalto", em "Teatro", p. 83), defuntos castrados ("queres que te peguem te castrem?/ teu corpo-estandarte/ à frente das hostes/ no alto?). Eis apenas alguns exemplos.

Em meio a esse funéreo cipoal, destaca-se o seguinte poema:

\section{RELÂMPAGO}

Sigo imóvel - morto - neste táxi.

Pressinto a arquitetura de sigilos - de segredos desdobrados.

- Desdobrando-se: - no princípio, o Ato. -

Resisto, na cidade, apesar: - 
esquivo, passivo, cativo, alvo de tanta verruma - de tanta espuma -, o Enrabado das esquinas, o Enforcado

no espelho, o Triste - o Triste -: o Triste

definitivo -

Resisto - nesta cidade - apesar.

Esqueço o revólver, desisto

de ir a Santos, despisto

a polícia. Peço 200, 300, 600.

Troco as pernas, escondo os braços.

O tempo me perde, o tempo me deve.

Meus olhos de saponáceo

devolvem terror.

Persigo o céu nas curvas

do Copan:

sequela e resto.

No cemitério, espremo o medo

geométrico, o espanto extremo.

$O$ mel difuso, a canivete.

Irmão de cera, irmão de barro:

irmão

O invés do sol

decomposto.

impresso no rosto.

O que for

me absolve.

Pinocchio te quer

morto.

Dividido em duas partes, o poema parece justapor vozes distintas. No primeiro segmento, assistimos a uma corrida de táxi em que alguém que se descreve como morto e afirma resistir à cidade, a esta cidade, apesar. Não se depreende de imediato o sentido da conjunção concessiva, embora seja possível intuí-lo com base nos recursos de autodesignação mobilizados pela voz em primeira pessoa. Assim, o morto que se desloca paradoxalmente pela cidade em estado de paralisia ("Sigo imóvel) desdobra as imagens de sua "impotência resistente", apresentando-se como alguém "esquivo, passivo, cativo", "enforcado", "enrabado" e definitivamente entristecido. Os agravos a ele infligidos 
parecem se relacionar à "arquitetura de sigilos", à vida das esquinas e, por fim, a uma relação de atrito com a cidade ("alvo de tanta verruma").

Essa cidade-verruma, que afeiçoa a identidade do sujeito por atrito, é o pressuposto subjacente do poema "Na marra" (p. 78), cuja dedicatória ("Para Antônio, em Copacabana") remete a uma cidade e a um contexto específicos. Nele, também encontramos uma situação de deslocamento/fuga, deflagrada por um grito de "¡fecha geral!”. Embora a fonte do imperativo não seja claramente identificada de início, ela sugere uma retirada forçada (comerciantes que baixam portas na iminência de algum arrastão? marreteiros acuados pelo "rapa"?) que também suscita resistência (““¡sai dessa pedra,/ marisco!'// - vivo ou/ morto; morto/ e vivo -// “isai dessa pedra!'”) e prenuncia desastre e delito ("nossa noite é criminal”). O clima de ameaça se potencializa pela personificação do cenário adverso: o mar que surra a avenida, cortinas que mastigam o dia a dia e, por fim, o arrancamento do marisco agarrado à pedra, cuja frágil blindagem atende mal à exigência de fechamento geral. A cidade então atua por abrasão dos que a habitam, muitas vezes em pânico, com sensibilidade molusca.

Em "Relâmpago", os efeitos subjetivos e a natureza criminal da abrasão só se tornam claros na segunda parte. Nela, uma segunda voz em primeira pessoa se contrapõe à primeira. A menção ao revólver e à polícia, bem como a valores ("Peço 200, 300, 600”), impele a pensar que o "ato desdobrado" seria algo como um assalto, ou melhor, um sequestro-relâmpago, o que elucida o título, reverberando ainda no verso "sequela e resto" - termos quase sinônimos, cuja aglutinação ressoa "sequestro" e que se referem ao céu sequestrado nas curvas do edifício Copan (o que também concorre para situar geograficamente o poema). Daí se depreende que alguém armado fez um refém e o obrigou a entrar em um táxi, que roda pelas ruas de São Paulo. Contudo, o sequestrador, que é também cobrador (“o tempo me deve”), nada tem da segurança da personagem que outrora inspirou o famoso conto de Rubem Fonseca: ele vai perdido e tão ou mais assustado que sua vítima. Seus “olhos de saponáceo", responsáveis talvez pela "espuma” de que é alvo o refém, compartilham o terror que ele experimenta. Ademais, o ritmo entrecortado pelo excesso de interpolações e travessões na primeira parte continua acelerado na segunda; a verruma cede lugar ao canivete e o medo fraterniza as vozes do réu e da vítima ("Irmão de cera, irmão de barro:/ irmão/ decomposto), ao mesmo tempo que lhes esculpe (e aproxima) 
as feições. Sob a égide da violência, o "relâmpago" aqui adquire a potência genésica de um fiat tenebrae (o "invés do sol”), que cria por decomposição e absolve por extermínio.

A imagem mais enigmática, porém, e que constitui uma espécie de nó semântico do poema, é a que aparece ao final - "Pinocchio te quer/ morto" - concluindo uma sequência de versos de cerrada tessitura sonora, em parte por causa das rimas com a mesma vogal tônica (o), variando o timbre entre aberto e fechado: decomposto/ rosto/ for/ morto; sol/absolve/Pinocchio.

Quanto à relação entre a violência citadina dos sequestros-relâmpago e a célebre personagem do italiano Carlo Collodi, podemos lembrar de imediato, na história do boneco, sua associação com "bandidos" (a Raposa e o Gato), que, no décimo quinto capítulo do livro, enforcam o fantoche por causa de algumas moedas de ouro ${ }^{36}$. E o próprio boneco também acaba por acarretar a morte de outras personagens, como o Grilo Falante, cuja cabeça é atingida por um cepo de madeira que Pinocchio lhe atira (no quarto capítulo). Além desses aspectos, Pinocchio, filho da madeira e da luz (a intervenção humanizadora da fada), dá ainda a pensar sobre a figura paterna elidida ${ }^{37}$, o que também, de outro modo, é uma questão nos poemas de Aleijão. Por fim, a utilização de uma referência do universo da literatura infantojuvenil, estabelece um laço inaudito entre violência e infantilização, igualmente explorada por outros poetas contemporâneos. ${ }^{38}$

Além desses nexos com a criminalidade/morte, a infância e a paternidade problemática, presentes na história de Collodi, o motivo do fantoche se vincula também a outros elementos de "Relâmpago" - como a verruma da primeira parte, o canivete da segunda e a ideia de sujeitos (em cera, em barro) plasmados (esculpidos, impressos) e

\footnotetext{
${ }^{36}$ Ele sobrevive porém à tentativa de homicídio e se recupera graças aos cuidados da Fada de Cabelos Turquesa no capítulo seguinte cujo fecho interessa-nos, no contexto desta análise, pela associação, em chave cômica, entre tristeza (no caso, choro) e ressurreição. Na casa de sua protetora, semimorto, depois de ouvir o Grilo Falante referindo o seu passado de malfeitos, Pinocchio se põe a chorar. O choro provoca o comentário do Corvo e da Coruja, "médicos" meio charlatões que, a pedido da fada, tratam dele, ao lado do Grilo Falante, médico prudente. Eis o texto:

“- Quando o morto chora, é sinal de que está prestes a se curar - disse solenemente o Corvo.

- Lamento contradizer meu ilustre amigo e colega - interveio a Coruja -, mas, para mim, quando o morto chora, é sinal de que não lhe agrada morrer". (Collodi, 2012, p. 132)

Em Aleijão, o choro, um dos atributos do "triste definitivo", aparece também em alguns poemas como um componente ao mesmo tempo teratológico e soteriológico, como nos poemas "Anatomia" (p. 89) - "Nunca reparou que os dentes vão quase até os olhos/ Que os dentes na verdade começam nos olhos (e uns como outros choram) - e "No jardim" (p. 95) - "esta é minha irmã com seus filhos/ soltos no jardim quase bichos/ é lenta são lentos como as/ coisas que ficam e por isso mesmo/ choram às vezes". Por fim, vale dizer que o cruzamento entre teratologia/morte e salvação/absolvição está também assinalado desde a epígrafe do livro de Sterzi,o canto de investidura real dos Mossi: "tu és um excremento/ tu és um monte de lixo/ tu vens para nos matar/ tu vens para nos salvar" (p. 5).

${ }^{37}$ Não por acaso, vários intérpretes tomam a história desse filho putativo de um carpinteiro como alegoria de Cristo (Calvino, 2012, p. $350)$.

${ }^{38}$ Ver, por exemplo, o poema de Heitor Ferraz, da coletânea Um a menos (2009) em que uma brincadeira infantil em cima de uma árvore, por supressão do contexto, ganha ares de execução: "Estou morto/ em cima da árvore/ Isso todos sabem só preciso soltar as mãos/ O corpo despenca/ levando folhas, galhos/ retalhos da blusa/ Os tiros vieram de baixo" (Ferraz Mello, 2009, p. 44).
} 
decompostos pelo medo. Ele ressurge ainda em outros poemas dessa seção. O já citado "Teatro" termina assim: "o escasso expõe nosso ex-voto/ no altar dos santos tortos/ fantoches fazendo chão" (grifo meu). E, em "Mão morta" (p. 92), lê-se: "ofereço a mão morta/ em espetáculo; a mão/ cadáver, que dança/ involuntária e desengonçada/ quando a rua chacoalha;/ mão de fantoche ou/ de espantalho [...]" (grifo meu).

O fantoche Pinocchio assoma então como mais um avatar do disforme (o aleijão, o monstro, o castrado/enrabado, o triste, o lento/paralisado), corpo inanimado que a rua chacoalha e o medo galvaniza. E sua aparição torna mais clara a relação especular (o "ato desdobrado") entre as duas partes do poema: ele é a vítima, o alvo, o rosto de treva, o pré-morto em que o sequestrador reconhece um irmão. É também aquele cujo desejo assassino absolve seu algoz.

No entanto, a frase final, "Pinocchio te quer/ morto", que intriga em função da passagem da primeira à terceira pessoa (me absolve $\rightarrow$ te quer), admite mais de uma leitura. Ela pode designar uma conversa do sequestrador consigo mesmo, sendo Pinocchio um terceiro (a vítima? o mandante?) que deseja sua morte. Mas Pinocchio pode ser também o próprio sequestrador, que se nomeia na terceira pessoa, caso em que o "te" designaria a vítima do sequestro. Ambas as leituras, porém, não alteram o essencial: seja Pinocchio a vítima ou o sequestrador, fato é que o terror é recíproco e, ao receio de estar morto, corresponde o desejo de matar, de ambos os lados.

Comparativamente aos poemas de Polito e Bonvicino anteriormente analisados, reconhecemos, pois, nesse "Relâmpago", um passo diverso na representação da violência, em função da aderência ao ponto de vista do agente delituoso. A fim de avaliar seu alcance, gostaria de fazer um novo e breve excurso.

Em texto recente sobre a representação da violência na poesia brasileira contemporânea, João Camillo Penna refere-se ao êxito artístico nessa seara em termos de um "recuo com relação ao grande discurso midiático da visibilidade criminal e às fábulas morais que produz" (Penna, 2011, p. 207). Para medir tal recuo, o crítico recorre às categorias do "terror" e da "piedade" que estão na base da catarse aristotélica, criando uma relação de longa duração entre a tragédia ateniense dos séculos V e IV a. C. e a violência contemporânea nas cidades brasileiras, com a justificativa de que a "a verdadeira matéria da tragédia é o pensamento social próprio da cidade" e a hipótese de que "elementos dessa 
primeira dramatização cívica sobrevivam hoje em dia na representação artística e, especificamente, no que nos interessa mais aqui, na poesia, e que esta elabore o 'pensamento social' que repercuta na cidade” (Penna, 2011, p. 208).

Sem questionar a impropriedade histórica dessa aproximação entre a Atenas clássica e o Rio de Janeiro contemporâneo, referido nos poemas de Armando Freitas Filho analisados no artigo - impropriedade que, aliás, perdura no salto que o crítico faz de Aristóteles a Agamben, passando pelo Direito romano, para desembocar enfim na noção de homo sacer -, limito-me a apresentar a ideia, proposta por Penna, de que, enquanto na tragédia clássica os afetos de terror e piedade eram suscitados pela mesma personagem, atingida pela catástrofe, no discurso midiático e policial, tais afetos sofrem dissociação, passando a se referir a diferentes personagens (a vítima suscita piedade; o criminoso, terror) e ensejando fábulas morais que polarizam o mundo social entre amigos e inimigos (e um tipo de catarse baseada no extermínio dos inimigos). O crítico conecta ainda essa dissociação ao excesso de "visibilidade vitimária" produzido pela mídia, que despolitiza/subjetiva a compreensão da violência social.

Com base nesses pressupostos, Penna se dedica à análise de três poemas de Armando Freitas Filho - "Imprensa", "Repisando a Candelária" e "Penalidade máxima", sobre incidentes criminais, respectivamente, a morte do menino João Hélio Vietes, em um assalto a carro, em 2007, a chacina da Candelária, ocorrida em 1993, e o assassinato da modelo Eliza Samudio pelo goleiro do Flamengo, Bruno Fernandes de Souza, em 2010.

As evidências de subversão do discurso policial e midiático apontadas pelo crítico, principalmente no primeiro e no último poemas, interessam-nos aqui de perto; indiquemolas rapidamente.

Em "Imprensa", a subversão consistiria em, basicamente, assumir o ponto de vista da vítima (o menino arrastado pelo carro), transformando-a de objeto em sujeito do olhar (em câmera subjetiva, o menino transfere ao entorno as marcas de seu corpo brutalizado). Contudo, ao se deter na personificação da cidade realizada no poema, de caráter metonímico ("o abrasivo pelo abrasado"), Penna passa ao largo de imagens que atenuam a letalidade do atrito: "Ruas ásperas, cortadas por outras:/ asfalto bruto, esquinas, lataria/ meios-fios desdentados, lancinantes/ que se irradiam por quilômetros/ de piso ruim, irritado por buraco/ pobreza, acne, suor ardido e sujo/ nas explosões nuas do tórax e bíceps". Acne? 
A pobreza, os obstáculos e a aspereza das ruas são equiparados a problemas cosméticos, dermatológicos, convertendo-se a morte do menino em um peeling no rosto da cidade. Menciono de passagem esse detalhe apenas para sugerir que a adesão ao ponto de vista da vítima não assegura de per si o recuo em face da espetacularização.

Já no poema "Penalidade máxima", a subversão se daria pela justaposição de duas cenas simétricas: a da cobrança do pênalti e a do assassinato de Eliza, em que tanto o goleiro como a moça seriam objeto de carnificina (com paralelismo entre a plateia de torcedores, a de assassinos e também a de leitores). O poema então superaria a dissociação entre terror e piedade, apresentando o goleiro ao mesmo tempo como monstro e vítima. Dessa maneira, heroifica-se o crime e se transforma o mandatário em objeto de compaixão, alguém que também é "consumido", "sacrificado" pelo espetáculo, pelo "peso da consciência”, pelo passado pobre, equiparando-se a morte metafórica dele à morte real dela. Mas em que medida isso contraria efetivamente o discurso midiático ou sua moral fabular? Tal moral talvez seja mais ambígua do que o crítico faz crer, o que nos impeliria a relativizar a ideia de que ela sempre funciona com base na dissociação afetiva entre piedade e terror, pois outros fatores aí intervêm - como o anonimato/celebridade, a classe social e o gênero do criminoso e de sua(s) vítima(s) -, podendo levar, em certas circunstâncias, à compaixão pelo algoz (se ele for homem rico e famoso e tiver matado uma mulher pobre e anônima) ou mesmo a misturas de tipo perverso (por exemplo, quando a mídia explora o sex appeal de assassinos).

Verifica-se, dessa forma, quão difícil é garantir o recuo da representação poética da violência em relação ao imaginário administrado pela tevê e pelos demais meios de comunicação, a serviço da cultura do pânico. Aderir ao ponto de vista da vítima, variar o ângulo de observação, nada assegura o recuo, mesmo porque a indústria do entretenimento também se aprimora em "mercadorizar" a dor, o trauma, de todos os ângulos, em versão 3D, 4D, por baixo da pele ou à distância de um satélite. Por conseguinte, a introdução de falhas e interrupções nesse regime escópico e discursivo parece depender da articulação entre várias coisas: ângulo, tempo de elaboração não compulsiva, uso do silêncio, apreensão das assimetrias entre os agentes traumáticos etc. De modo semelhante, a subversão da moral fabular ativada por episódios de violência deve levar em consideração ambiguidades e diferenças na mobilização afetiva da opinião pública. 
Finalizando, pois, o excurso e voltando a "Relâmpago", de Sterzi, observamos que o poema rompe com a dissociação afetiva supostamente subjacente do discurso midiático e policial (o que já demonstramos ser questionável), ao criar certa reversibilidade entre as disposições anímicas do sequestrador e do sequestrado, ambos assestados pelo sentimento de horror. Não se trata, porém, do horror pasteurizado pela mídia, em parte porque o delito em curso não progride para o deslinde-padrão (tiros, prisão, morte) que constitui o filé-mignon dos noticiários. O poema se concentra nas tensões da espera torturante que, no entanto, enseja resistência e absolvição.

No que concerne à representação das fronteiras de classe dos atores sociais envolvidos - uma de nossas preocupações ao início deste capítulo -, vemos que é tênue a determinação do ato delituoso (desenhado mais em função de suas consequências, que aproximam agressor e vítima, que de suas causas) e, digamos, fraca a sensação de socioalteridade, já que as duas vozes se assemelham em termos de linguagem e recursos expressivos, como se se tratasse de emanações de um mesmo eu lírico.

De toda maneira, a indiferenciação entre vozes e a caracterização do crime pela via dos efeitos talvez tenham sido propositalmente buscadas, para enfatizar a comunidade de destino entre os envolvidos, ambos esculpidos/modelados pela "única lei inflexível/ desta cidade:// a lei de um rosto desfeito/ a marteladas", conforme se lê no poema "Estrangeiro" (p. 101), a mesma lei por trás do "rosto decomposto" em "Relâmpago", da cabeça desmanchada a chutes em "Jogo" (p. 98) ou dos automatismos da ira em "As armas [ou: Também o sabes]”(p. 100). “As armas...”, aliás, retoma o tema do sequestro presente em "Relâmpago" da perspectiva de um suposto casal que, armado, tenciona "estourar o cativeiro" onde jaz aprisionada uma familiar. O poema é habilmente construído com perguntas cuja resposta já se sabe, repetições de verbos ("não digo e não dizes"; "conheces conheço a tocaia") e supressão completa da pontuação ("minha mulher tua irmã foi levada") que "compactam" a dupla armada em um bloco indiviso de angústia.

Sem embargo, a despeito da variedade de personagens e vozes em jogo nesses poemas, certa uniformidade do impulso lírico contém a inflexão para o dramático, o que não impede a figuração aguda da violência (associada por vezes a acertos de conta com o pai terrível e seus representantes), que forma e deforma seus habitantes, fantoches de emaranhado cordel. 
Vejamos, porém, um último exemplo de figuração da violência, em que, ao decortinar um quadro mais multifacetado das várias forças que atuam simultaneamente na composição da violência urbana, cruzando fronteiras de classe (de gênero, etárias etc.), o registro lírico se instabiliza, abrindo-se a uma diversidade de vozes ${ }^{39}$.

VI. A cabeça e a pedra

\section{COSMOVISÃO DA PÁ}

I

professora

não fui à aula ontem porque os meninos das armas não deixaram

mamãe também não foi trabalhar

ficou triste porque vai perder o emprego

mas os meninos das armas ficaram mais tristes

porque o amigo deles morreu

ele tava sempre na rua

agora não tá mais

quem morrer não pode mais sair

ele sempre saía com armas grandes

iguais às da televisão bonitas

ele perdeu as armas e deixaram de castigo pra sempre

porque ele não saiu mais

sem sair de casa

será que eu morri também?

se eu não morri, vou levar a minha pra escola

professora

quando eu atirar

estarei vivo

\footnotetext{
${ }^{39}$ Em artigo de setembro de 2013, Flora Süssekind reflete sobre a ressurgência de experiências corais na vida cultural brasileira recente como sinal de um "esforço de figuração da dimensão coletiva, apresentada, por vezes, de modo espectral, como "comunidade ausente"” Tais coralidades constituiriam uma forma de interrogação "tanto da hora histórica quanto do campo mesmo da literatura", criando "objetos verbais não identificados", pelo difícil enquadramento em categorias e gêneros tradicionais e pela suspensão intencional da formalização. A autora conecta os exemplos literários aos oriundos de outros campos artísticos (filmes como $O$ som ao redor, o protagonismo-coral do Teatro Oficina, as experiências sonoras do Chelpa Ferro etc.). Entre as coralidades literárias atuais, cita, por exemplo, o $O$ de Nuno Ramos, As visitas que aqui estamos, de Antonio Geraldo Figueiredo Ferreira, Engano geográfico, de Marília Garcia, Delírios de Damasco, de Veronica Stigger. (Süssekind, 2013)
} 
Redação: O que é globalização

A minha arma é mad in usa

então é pra usar

usa quando explode a cabeça do outro

mas o mad não sei o que diz

mad usa

deve ser algo que explode também

III

eu vi a cabeça no chão. mas foi a pá que gritou.

(Cinco lugares da fúria, 2008, p. 83-4)

À diferença dos exemplos anteriores, nesse poema de Cinco lugares da fúria (2008), de Pádua Fernandes, a voz da pobreza e da periferia, caracterizada com riqueza de detalhes, acede ao primeiro plano na figura de uma criança que não pôde ir à aula porque foi impedida pelos "meninos das armas". A violência aqui comparece não como eventualidade ou risco, mas como fato total, estrutura de mundo (cosmovisão) em que a morte perde o sentido ao se tornar onipresente.

O esforço da criança passa a ser então o de repor esse sentido mediante equiparações distorcidas, filtradas pela perspectiva infantil, de grande impacto: morrer é não estar mais na rua, não poder sair de casa, ficar de castigo para sempre. O equívoco caminha velozmente e atinge seu mais alto grau ao suscitar dúvida sobre a própria condição: “sem sair de casa/ será que eu morri também?”. Tal dúvida, que não chega a ser dirimida (como indica a presença do "se" condicional no início do verso subsequente), conduz à equiparação alucinada entre morte e vida, que fecha o círculo da violência: "quando eu atirar/ estarei vivo".

A afirmação assinala certo clímax, ao que se segue um segundo momento da conversa do menino com a instituição educacional, por meio de uma redação sobre a globalização, que conecta a violência às grandes redes transnacionais. Note-se também, nesse trecho do poema, a deformação sarcástica da expressão inglesa made in usa. $\mathrm{O}$ erro (que transforma made em mad e lê na sigla "usa" a flexão homógrafa do verbo "usar", em português) explicita o processo de enlouquecimento ( $\mathrm{mad}$ ) resultante da equiparação morte- 
-vida. Enlouquecimento em que a explosão da cabeça deve ser entendida tanto em termos psicológicos (o próprio pensamento despedaçado) como físicos, pois os disparos hão de estilhaçar o alheio crânio, em uma lesão que congraça assassino e vítima.

No desfecho, a mudança no tempo e no modo verbais marca a consumação do gesto que dá à luz o cadáver: em vez dos hipotéticos "quando eu atirar" e do "deve ser", temos o grito no pretérito perfeito; grito que a criança projeta na pá por meio da personificação. E a pá que grita remete novamente ao título: paradoxalmente, é dela a cosmovisão. Nesse sistema em que a morte deixa de ser um limite imposto ao futuro para se converter no próprio futuro, não admira que a visão integradora seja dada não de um ponto de vista recuado, mas antes pela proximidade excessiva, que abrevia o pensamento e a dor.

Afora isso, no que concerne à organização formal, o poema não parece encerrar maiores dificuldades: frases diretas, em registro coloquial, andamento de prosa. No entanto, sua interpretação demanda a consideração dos textos que o antecedem ${ }^{40}$ integrando o quarto dos cinco furiosos lugares - a seção intitulada "Língua pródiga dos decapitados", dedicada aos entrelaçamentos entre violência, arte e escrita. A língua aqui é tanto o idioma como o músculo que deve ser extirpado em sessões de tortura e arte experimental (ver, por exemplo, a parte IV do poema inicial "Galeria", em que, em uma exposição, um artista expõe como sua uma língua arrancada às classes populares, pois "a arte fala através da língua do povo"). Em "Eloquência e decapitação", que se encerra com a morte de uma sem-teto, esse vínculo entre poética e destruição aparece de modo claro em versos como "é a ruína que escreve/ e constrói novos aposentos onde a pedra antes reinava".

Assim, a redação em "Cosmovisão da pá” coroa essa sequência de escrita e aniquilamento. A pá, que em "Eloquência e decapitação" fora usada para esconder "os ossos do fôlego", é o complemento necessário da metralhadora, ambas instrumentos de alfabetização pela cartilha das ruas.

Portanto, na cidade que emerge a partir daí, vista da perspectiva da população de baixa renda, a violência comparece não como risco a deflagrar atitudes paranoicas ou ansiogênicas, mas como destino a que se reage pela clausura e pelo enlouquecimento da percepção e do discurso. A tarefa escolar executada em meio à matança conserva o travo de

\footnotetext{
${ }^{40} \mathrm{Se}$, em qualquer conjunto de poemas, é de suma importância considerar a posição do poema em relação ao conjunto, as recorrências, os contrastes e as sobreposições, em Cinco lugares da fúria tal consideração adquire importância redobrada devido à construção polifônica, em que um mesmo tema é perseguido por diferentes vozes em uma estrutura de tipo contrapontístico.
} 
horror, acentuado pela defesa, que recorre à identificação projetiva, atribuindo à pá a atitude de choque, ausente no discurso do menino.

Sinais desse mesmo horror podem ainda ser identificados, sob outro arranjo, na segunda seção de Cinco lugares da fúria, intitulada "Percursos anti-horários da pedra". Narra-se aí, de modo não linear, a morte de uma mulher atingida acidentalmente por um disparo de fuzil em uma troca de tiros entre uma viatura da Polícia Militar e um bando de trinta saqueadores em fuga.

A seção é dividida em sete partes, ordenadas em sequência não cronológica: zero, dois, três, quatro, cinco, menos do que um, um. Grosso modo, o autor inicia com a descrição do cadáver da moça para apresentar retrospectivamente elementos de sua biografia associados a violências pregressas, em prelúdio à violência final do tiro que a liquida. Alternando o foco narrativo, ouvimos a voz de um advogado trabalhista que tenciona lesá-la em um processo contra a cooperativa em que ela trabalha; a voz de seu padrasto, que dela abusa sexualmente; a voz do autor do tiro; a voz de políticos em negociata... entre muitas outras. Cada uma das vozes se acomoda em diferentes moldes métricos e rítmicos: diálogos em prosa, tercetos eneassílabos, dísticos heptassílabos etc.

A voz do padrasto estuprador, por exemplo, alude em chave paródica ao "Soneto da fidelidade" de Vinicius de Moraes, retificando com sarcasmo a metáfora ígnea do amor: "logo mais o amor lhe ensina/ como a tudo sou atento// pois não é porque termina/ que chamam o amor incêndio// mas devido à cicatriz/ que é do fogo todo o prêmio".

A voz do assassino, que se segue à do padrasto, também apresenta sinais de crueldade alienada, sobretudo nas comparações com Deus e nos contrastes entre vida e noite, aborto e luz:

\section{CINCO}

na hora não sinto nada. só depois é que eu esqueço. um cigarro. não tem. foi preciso. estava no caminho. ela foi lá, então deus quis. quase que não fui eu. poderiam ter sido todos. então não foi ninguém. na hora não sinto, depois esqueço e sei de tudo. saiu no jornal 
mas não tenho mérito. deus mata

muito mais do que eu. nunca

matei meu próprio filho. paguei aborto antes.

então dei à luz de nunca nascer.

a vida é que tem a noite.

na hora é que eu esqueço.

depois eu sinto e não sei nada.

não foi ninguém, ninguém morreu.

foi só algo que estava no caminho.

uma fumaça. passou. não foi

como meu filho. que nunca passou. é luz.

a noite é que tem a vida.

ela saiu no jornal. mas já fiz melhor.

um cigarro. eu gosto, queima.

(Cinco lugares da fúria, 2008, p. 45)

Aqui também, como em "Cosmovisão da pá", o discurso vai se enredando em paradoxos e incoerências que revelam a dificuldade de assimilação do homicídio. Logo de início, a menção à anestesia imediata ("na hora não sinto nada") parece contradizer a confissão do que custa a ser esquecido ("só depois é que esqueço”). Essa incoerência retorna algumas vezes, funcionando como uma espécie de bordão com variações de tipo permutativo ("na hora não sinto, depois esqueço/ e sei de tudo", "na hora é que eu esqueço./ depois eu sinto e não sei nada", "a vida é que tem a noite", "a noite é que tem a vida") e atestando o irredutível descompasso entre sensação, memória e consciência.

Somam-se a tal descompasso outros raciocínios "falhados", como aquele que nega a autoria do crime, coletivizando-o ("poderiam/ ter sido todos. então não foi ninguém”), para em seguida negar o próprio ocorrido (“não foi ninguém, ninguém morreu”).

Creio que um dos pontos altos do poema está na menção à figura do Criador, cuja crueldade diante da crucifixão de Cristo é invocada como termo de comparação com o assassino, que, pagando pelo aborto do próprio filho, pareceria mais piedoso, dando "à luz de nunca nascer". Tudo então se embaralha: nascimento e assassinato, luz e treva, inocência e culpa. 
Curiosamente, o efeito alienante produzido pela violência sobre seus agentes e vítimas é contraposto à onividência da própria cidade, que a tudo assiste com os olhos que a violência lhe abre: “os buracos são olhos de quem/ no muro perfurado por balas?”. 41

Constela-se então a cena urbana pela multiplicação de pontos de vista, processo que atinge seu grau máximo no poema que encerra a seção, no qual é descrita a morte de Mérilim da Cruz e Silva e Santos (nome de atriz hollywoodiana desglamorizado pelo aportuguesamento da grafia, pela cruz do sobrenome e pela redução progressiva, ao longo do poema, às iniciais M.C.S.S.). Ali, em uma espécie de sinfonia coral, reúnem-se a vítima, perdida em seus últimos pensamentos de autodefesa (contra a cooperativa que a explora, contra o padrasto que dela abusa); um médico dividido entre o frágil senso de dever profissional e o imperioso desejo de escapar do engarrafamento; os policiais da viatura atraídos por Mérilim ("que gata/ quem sabe ela se amarra numa farda"); o motorista de ônibus, que se detivera antes do ponto, temendo ser assaltado pelo bando de saqueadores e, por fim, os bandidos em fuga (avisados por funcionários do Palácio, depois de comprar armas do próprio exército).

A narração oscila entre o discurso indireto e o indireto livre, entre o relato objetivo das ações e a reprodução do pensamento dos envolvidos, assumindo, ao final, uma voz diferenciada, distinta das anteriores, para descrever a queda do corpo fuzilado ("mas o salto que recorta o ar e o ar o acolhe, o passo que imita o raio e o raio o ilumina, que -"). Esse infausto momento em que a carne enfim conhece a pedra (o que remete novamente ao título, "Percursos anti-horários da pedra") é secundado pela inversão do adágio ("Antes nunca do que tarde"), cuja sensatez resignada, a despeito da impotência, converte-se em recusa, inconformismo.

A propósito dos impasses e desequilíbrios temático-expressivos na representação da violência talvez valesse a pena mencionar como nesses poemas Fernandes mistura recursos estilísticos da poesia tradicional - as metáforas ígneas para o amor (subvertidas para enfatizar a agressão de gênero), os paradoxos à maneira barroca ("dei à luz de nunca

\footnotetext{
${ }^{41}$ No terceiro capítulo, voltaremos a tratar dessa aplicação de metáforas corporais à cidade, traço recorrente na poesia de Fernandes.
} 
nascer”) e os jogos permutativos - a trechos em prosa e a elementos dramáticos, com multiplicação de vozes, em um tipo de formalização muito variado, que não estabiliza as tensões temáticas em sínteses líricas nem elide as coordenadas concretas da "fúria" em excessos metaforizantes, metalinguísticos, tampouco a banaliza por meio da exploração anedótica do grotesco e do abjeto.

Isso se relacionaria de certa maneira à multiplicação de pontos de vista na observação da cidade e à variação na distância social entre a voz poética e os alvos (ou agentes) da violência ao longo dos versos? Vale recordar que a descrição da personagem Mérilim não é monopólio de um narrador único e que os efeitos retóricos que dão prova do consórcio entre os interesses da classe dominante são abertamente ironizados (ver, por exemplo, a fala do advogado na parte "três").

\section{Figurações da violência: recusa mimética $\times$ ansiedade referencial}

Vimos então diferentes maneiras de representar a violência urbana, que não autorizam generalizações ou afirmações conclusivas sobre a poesia brasileira contemporânea. Enquanto em Polito destacamos o movimento regressivo de retorno à natureza e ao indiferenciado como resposta às tensões decorrentes da segregação socioespacial, em Bonvicino detivemo-nos nas imagens alucinatórias associadas ao encontro com um morador de rua e em Sterzi destacamos a reversibilidade entre agressor e vítima em uma cena de sequestro, ambas "ventrilocados" pelo medo como inertes marionetes. Em Fernandes, por fim, ocupamo-nos do tratamento polifônico de uma narrativa criminal, em que as múltiplas dimensões da experiência urbana vão sendo convocadas pela alternância de vozes, tons e modalidades discursivas, muitas vezes com desconstrução de expressões cristalizadas (jargão político/policial, retórica religiosa, provérbios populares etc.) e arremedo calculado da tradição lírica (como na gozação com Vinicius de Moraes).

Contudo, antes de encerrarmos o capítulo, seria oportuno situar os exemplos de que nos ocupamos aqui em relação a algumas posições críticas sobre a representação da violência na literatura brasileira recente. 
Flora Süssekind (2005), em abrangente ensaio dedicado ao assunto, distingue na produção contemporânea duas vertentes de enfrentamento da experiência urbana. A primeira delas, mais presente na prosa de ficção que na poesia, investe na representação de tipo documental, etnográfico, de cunho descritivo e pode ser encontrada em manifestações díspares como as letras de rap, a literatura carcerária, o romance neonaturalista do tipo Cidade de Deus, de Paulo Lins, e Capão Pecado, de Ferréz. Em tal vertente, a forma literária aspira à duplicação do real por meio de representações explícitas, da incorporação hipermimética de imagens e discursos urbanos (expressões de gueto, crônica da barbárie), amiúde nos moldes de um catálogo patológico-criminal. Segundo Süssekind, tais representações conduziriam a uma escrita de tipo convencional, parajornalístico, que neutraliza os recursos narrativos em favor de uma visão estereotipada e a-histórica dos grupos socialmente marginalizados. ${ }^{42}$

A tal vertente, porém, outra se oporia: uma em que, à luz da condição urbana atual, os recursos formais se complexificam mediante a "produção de espaços não representacionais e de zonas liminares, ambivalentes, transicionais de subjetividade" (Süssekind, 2005, p. 61). Aí entram vários exemplos da produção poética dos anos 1990, representada por autores como Sebastião Uchoa Leite, Duda Machado, Ítalo Moriconi e Ângela Melim, entre outros. Enfatizam-se então, nessas obras porosas ao rumor citadino, a indeterminação identitária do sujeito poético (por exemplo, na poesia de Sebastião Uchoa Leite, amiúde pontuada por micronarrativas de perseguição, com reversibilidade entre os papéis de vítima e perseguidor) e da paisagem (sobreposição de diferentes cenários ao espaço urbano, com mistura entre mundo interno e ambiente exterior), a figuração deformante (como nos "in-seres" de Uchoa Leite), os mecanismos de dissociação da voz lírica, o deslocamento da perspectiva de observação (que se opõe à fixidez do olhar colecionista da vertente neodocumental) etc. Ainda segundo a ensaísta, tais recursos de indeterminação e desterritorialização não se limitariam a inventariar a experiência urbana, funcionando antes como índices da confusão instaurada por novos padrões de sociabilidade “em cidades pautadas simultaneamente por uma homogeneização globalizadora do espaço e por uma exacerbação do pânico da heterogeneidade social”(Süssekind, 2005, p. 69).

\footnotetext{
42 “A neutralização do processo narrativo em prol de um inventário imagético, de uma imposição documental, tende, todavia, tanto à reprodução de tipologias e conceituações correntes, estandardizadas com relação a essas populações, quanto ao congelamento da perspectiva (à primeira vista, aproximada) de observação numa presentificação restritiva, estática, fundamentada no modelo da coleção, e não na experiência histórica propriamente dita.” (Süssekind, 2005, p. 63)
} 
Conquanto seja possível identificar também na poesia contemporânea casos ilustrativos da vertente neodocumental aqui descrita, os exemplos coligidos por Süssekind restringem-se ao campo da prosa, enquanto, na vertente oposta, misturam-se poetas e prosadores (ainda que as análises mais pormenorizadas concentrem-se na poesia) ${ }^{43}$.

De uma perspectiva teórica diversa, Iumna Simon (2008) procura, como já dissemos, entender de que maneira a poesia brasileira se abre hoje para problemas como o da violência urbana após um período relativamente longo (que se estendeu da segunda metade dos anos 1980 até meados da década seguinte) em que, a despeito dos diferentes projetos em curso, investiu-se predominantemente em uma poética da rarefação ou diluição das referências à realidade nacional. Tal poética se prenderia, conforme explica a autora, a uma relação pacificada e frívola com a tradição, à valorização pós-moderna da intertextualidade, à busca de padrões "aliteratados" como resposta à crise representacional. Contudo, do final dos anos 1990 em diante, verificar-se-ia, em uma série de obras e autores, o tal "retorno do real" por meio da tematização explícita de problemas da sociedade brasileira, entre os quais o da violência urbana.

Em artigo dedicado à análise do poema "Sítio", do livro Margem de manobra (2005), de Cláudia Roquette-Pinto, entre as hipóteses aventadas para explicar por que "a relação tão insatisfatória com a realidade atual demorou tanto a chegar à poesia num país em que a violência é constitutiva da própria realidade", Simon cita o ensaio de Süssekind como representante de uma atitude teórica e estética que, ao condicionar a complexidade (a criatividade, o potencial crítico) da forma literária à recusa mimética ${ }^{44}$, talvez tenha contribuído para retardar "a incorporação distanciada e crítica da violência contemporânea". (Simon, 2008, p. 165)

De outro lado, na avaliação de Simon, o que se elogia na obra de Roquette-Pinto é justamente o uso da indeterminação sintática, da dissolução referencial, da metalinguagem como recursos de representação indireta de angústias socialmente produzidas; recursos cuja

\footnotetext{
${ }^{43}$ O que até era de esperar, considerando que a mediação lírica se contrapõe à vocação mais mimética da prosa...

${ }^{44}$ A esse propósito, Antoine Compagnon faz ver como a tradição de crítica à mimese - subversiva em Platão e repressiva em Barthes, por exemplo, que identifica a ilusão/convenção realista à ideologia burguesa - justifica-se com base em uma interpretação restritiva da mimese aristotélica (em que a verossimilhança deixa de se referir ao sentido natural, ao domínio do "eikos", do possível, para se referir ao domínio cultural, da "doxa") e uma crítica da ilusão referencial que simplifica as relações intertextuais, transformando, por conseguinte, o contexto em cotexto. “[...] alors que, pour Jakobson, le contexte était en vérité du hors-texte, c'est-à-dire le réel, et que la fonction référentielle y était précisement attachée, le contexte n'est autre, chez Rifaterre, que du texte (du co-texte, si l'on veut) [...]”. (Compagnon, 1998, p. 130). No entanto, em contraposição a esse modelo de mimese como cópia ou decalque do real, Compagnon, apoiado em autores como Northrop Frye e Paul Ricoeur, vai retomar a ideia de uma mimese como aprendizagem e experiência temporal, recuperando seu valor heurístico e público.
} 
força é algumas vezes comparada à fraqueza de outros modos de figuração da experiência urbana, marcados pelo "fetiche do factual" 45 .

No poema "Sítio", por exemplo, o dado de violência (a bala perdida que atravessa a cabeça de uma criança na varanda) recebe tratamento que destoa da banalização noticiosa, justamente graças ao filtro imagético da autora (imagens obscuras, de cunho introspectivo, ligadas à natureza, ao universo feminino ${ }^{46}$, doméstico, burguês), o qual relaciona de modo inesperado as instabilidades do mundo íntimo à desordem social.

Em artigo posterior dedicado ao livro Corola, da mesma Roquette-Pinto, Simon e Dantas (2009) descreverão o que especifica a dissolução referencial nessa obra. Os autores empenham-se em demonstrar de que maneira a perda do referencial nesse livro não é objeto de espetáculo nem motivo de regozijo, como ocorre na metapoesia brasileira recente. Ela antes ocorre

num quadro inomeado de regressão e violência, de miséria psíquica, a partir da experiência de um corpo que não quer morrer, cujos dilemas sensório-perceptivos possuem teor de realidade para além da indeterminação textual com que, de imediato, se expõem ao leitor. (Simon e Dantas, 2009, p. 230)

Mais do que desrealização, os críticos identificam o que eles vão chamar de "ansiedade referencial", a qual não suprime os nexos narrativos e se presta à simulação de um lirismo impotente, bloqueado. Trata-se, portanto, uma poesia desconfiada da potência metafórica, da autoconsciência e do rigor construtivos; uma poesia porosa à violência (histórica, não ontológica), avessa a qualquer "heroísmo da forma".

Tais considerações parecem confirmar a necessidade de investigar mais longamente os impasses da tradição mimética na poesia urbana. Como vimos, sobretudo quando se trata de representar a violência social, podemos discernir, no seio dessa tradição, respostas estereotipadas (a vertente documental, fetichista, espetaculosa) e respostas em que a

\footnotetext{
${ }^{45}$ Página órfã (2007), de Régis Bonvicino, é o contraexemplo escolhido pela autora. Ressalta nesse livro um tipo de denuncismo raivoso e ingênuo, maniqueísta.

${ }^{46}$ Especificamente no caso de "Sítio", Simon destaca o filtro das referências domésticas e femininas, subestimando, talvez, o peso da intertextualidade na gênese de algumas imagens. Assim é que talvez os "panos úmidos, mudos/num caldo sujo de claras em neve" e o mar como "cachorro imenso/ trêmulo,/ vomitando uma espuma de bile" parecem dever muito ao "Cão sem plumas" de João Cabral de Melo Neto: "O rio ora lembrava/ a língua mansa de um cão,/ ora o ventre triste de um cão,/ ora o outro rio/ de aquoso pano sujo/ dos olhos de um cão".
} 
diluição referencial (que em tese se inclinaria para o campo da "recusa mimética") pode revelar aspectos da realidade não tematizados de modo explícito (como é o caso de Corola, em que os dilemas perceptivos conectam-se à experiência urbana, aparentemente recalcada nos versos).

Mas como tais questões se colocam nos poemas comentados neste capítulo? Em “Devassa, devastação", destacaram-se o caráter indeterminado da destruição, a ausência da cidade concreta e o fecho metafórico-monumental, que estabiliza demais a composição. Já em "Vivência", o que ressalta é a evasão fusional, a expansão lírica, que também abafa as tensões representadas na primeira parte do poema.

Em Bonvicino, vimos como as tensões da mixofobia alcançam expressão a despeito de certa indeterminação decorrente da proliferação metafórica e continuam ativas mesmo no desfecho, em que a transição para o espaço íntimo não embota o gume das imagens pânicas.

Em Sterzi, exploramos as ressonâncias afetivo-familiares da violência nas ruas, examinando o contraponto entre perspectivas dos atores sociais num episódio traumático, em que a inflexão para o dramático é contida por certa uniformidade das projeções do eu lírico.

Para concluir, em Pádua Fernandes testemunhamos como a voz do poeta, sem se prender a um ponto de vista único, se encarna em diferentes personae e passeia por vários registros discursivos.

Poderíamos, contudo, nos perguntar se em Cinco lugares da fúria também não haveria espetacularização da desgraça, sobretudo quando a violência é representada de modo direto. Não penso ser esse o caso, considerando que aí não há concessão ao pitoresco, nem congelamento de perspectiva, nem contraposição ingênua do sublime artístico ao “mundo cão". Bem ao contrário disso, a alternância de vozes, os enxertos de prosa, as irrupções líricas e as brincadeiras paródicas produzem continuamente dissenso e desconforto. 


\section{Capítulo 2. "Se eu perder esse trem": verso e revés na cidade bloqueada}

\section{I. "Circulando, circulando": paradoxos da mobilidade}

Uma das principais contradições da vida urbana degradada ao longo das últimas décadas diz respeito à combinação paradoxal entre paralisia e mobilidade. Conforme vimos no capítulo anterior, se, de um lado, a ideia de fluxo impõe-se sobre a de território, submetendo pessoas, produtos, informações à ditadura do movimento e da uniformização, do deslizamento contínuo, exotópico, pelas metageografias da metropoleletrônica (Di Felice, 2009), pelos ambientes virtuais do mundo-cidade, de outro, nas cidades-mundo ${ }^{47}$, prospera a segregação socioeconômica e toda a sorte de enclausuramentos, opondo as elites flutuantes, conectadas às redes transnacionais de consumo e entretenimento, à população pobre nas periferias guetificadas, nas favelas planetárias ou vivendo ao relento, no olho da rua, exposta a todo tipo de violências.

À aceleração tecnológica (pela qual, em tese, é possível fazer tudo, aceder a todos os produtos e informações sem se deslocar), que dificulta a percepção do movimento pela criação de um espaço-tempo contínuo, espécie de presente perene, intransponível, correspondem certos “abcessos de fixação" (Augé, 2010, p. 16), de sedentarismos forçados que desdobram a ideia de "não lugar" em formas triunfantes, espaços de comunicação e consumo, e formas nuas, espaços vazios, como as zonas brancas mapeadas por Philippe Vasset, pelas quais cidades como Paris, Lagos e Rio de Janeiro se assemelham em suas margens e se comunicam entre si "como as bacias de uma barragem" (Vasset, 2007, apud Augé, 2010, p. 37).

Sabe-se também quanto a produção material do espaço urbano, as ações do Estado (investimentos no sistema viário, localização dos aparelhos estatais, legislação urbanística) e os discursos ideológicos (o mito da cidade global ou as pseudopromessas de fluidez, no modelo rodoviarista de urbanização, por exemplo) são dominados pelas elites econômicas, que atuam de modo a otimizar o tempo por elas despendido em deslocamentos espaciais (Villaça, 2012, p. 66). Enquanto a população de baixa renda consome a maior parte de seu tempo em deslocamentos entre moradia e trabalho, os ricos tendem a ter o emprego e a

\footnotetext{
${ }^{47}$ Sobre o contraponto entre mundo-cidade e cidade-mundo, ver Augé (2010, p. 9).
} 
moradia concentrados na mesma área (que em São Paulo corresponde ao Quadrante Sudoeste da cidade), além de praticarem outros tipos de deslocamento (moradia-lazer, moradia-escola, moradia-compras e serviços), muito menos frequentes no caso dos pobres.

Apesar de a crise de mobilidade ter-se tornado tema assíduo nos noticiários (que, em uma cidade como São Paulo, não cessam de anunciar novos recordes de lentidão), é curioso também verificar como tal crise é frequentemente reduzida ao problema do congestionamento $^{48}$ e como as políticas públicas, apesar de investimentos recentes na ampliação do metrô e da modernização de trens e ônibus, continuam privilegiando o transporte individual, isto é investindo na ampliação física e na modernização da gestão do sistema viário. A redução da imobilidade ao congestionamento é expressão desse privilégio (Rolnik e Klintowitz, 2011) oferecido ao transporte individual em detrimento da ampliação e modernização dos transportes coletivos - embora a mobilidade dos usuários de trens e ônibus seja muito mais prejudicada que a dos passageiros de automóveis, e as viagens em transporte coletivo representem a maior parte dos deslocamentos feitos em uma grande cidade. Na Região Metropolitana de São Paulo, por exemplo, em 1967 (época de grande investimento em obras viárias) o transporte individual representava apenas $31,9 \%$ do total das viagens motorizadas. Em 2007, esse percentual continuava sendo inferior ao das viagens no modo coletivo $(44,7 \%)$ e pouco significativo para a população de baixa renda (correspondendo a apenas $23,2 \%$ das viagens motorizadas empreendidas por pessoas com renda familiar até 760 reais). ${ }^{49}$

Ainda usando o exemplo de São Paulo, podemos aquilatar o grau de paralisia que acomete a cidade com base em outros dados. Enquanto a construção de rodoanéis, túneis e vias expressas consome bilhões de dólares, o metrô que atende a Região Metropolitana é muito menor que o de Santiago do Chile (onde a malha metroviária tem $94 \mathrm{~km}$ e foi construída a um custo muito mais elevado, por causa da necessidade de proteção contra terremotos), cuja população é um quarto da população da Grande São Paulo e metade da do Grande Rio. ${ }^{50}$ A extensão atual da malha metroviária paulistana $(74,3 \mathrm{~km})^{51}$ corresponde a

\footnotetext{
${ }^{48}$ Após as manifestações de junho de 2013 iniciadas pelo Movimento Passe Livre, em defesa da redução da tarifa, objetivo rapidamente alcançado, e do transporte gratuito em médio e longo prazo, a pauta de discussão se ampliou. Este capítulo, porém, escrito antes disso, refere-se a uma situação anterior, de menor consciência da opinião pública sobre a crise do transporte.

${ }^{49}$ Pesquisa Origem e Destino. Região Metropolitana de São Paulo. Síntese das Informações da Pesquisa Domiciliar (Metrô, 2008).

${ }^{50}$ Cf. Villaça (2012, p. 247).

${ }^{51}$ Informação disponível em <http://www.metro.sp.gov.br/index.asp>. Acesso em: 16 fev. 2012. Na página de abertura aparece esse dado sobre a extensão da malha metroviária, assim como a estimativa de 4 milhões de usuários/dia. No entanto, os dados obtidos na parte do site dedicada a estatísticas estão desatualizados (referem-se à situação em dezembro de 2010) e falam em uma malha de 65,3 km.
} 
pouco mais de um terço da malha da Cidade do México (201,3 km), onde o metrô começou a ser construído na mesma época. A rede ferroviária, cuja extensão chega a 260,8 km, tampouco compensa a pequenez do metrô, devido à irregularidade do serviço e aos baixíssimos índices de conforto - a espera pode chegar a vinte minutos, com concentração média de quase nove passageiros em pé por metro quadrado, segundo dados da Companhia Paulista de Trens Metropolitanos (CPTM) para maio de 2009. ${ }^{52}$ A título de comparação, vale lembrar que em 1933, quando a população da cidade São Paulo era de 888 mil habitantes, a malha do sistema de bondes, responsável por $84 \%$ dos deslocamentos em transporte coletivo, era de $258 \mathrm{~km}$ (Rolnik e Klintowitz, 2011, p. 90). ${ }^{53}$

A utopia da motorização individual (a liberdade de um transporte não subordinado a trilhos ou horários) converte-se facilmente em prisão quando o automóvel populariza-se, estendendo-se à sociedade como um todo (Schor, 1999, p. 108; Maricato, 2011, p. 172). Tendo determinado nos países capitalistas centrais um tipo de urbanização fragmentada e dispersa, com baixa densidade de ocupação, e atiçado o capital imobiliário em direção a empreendimentos como os condomínios fechados e shopping centers no entroncamento de avenidas e rodovias, a "carrolatria" matou a rua e o pedestre ("pedestre, perdeste", constata um grafite espalhado em algumas faixas de pedestres de São Paulo) e também esvaziou áreas centrais urbanas, que, abandonadas pela elite, passam a ser ocupadas pelas camadas mais pobres da população até que o mercado imobiliário volte a se interessar por elas, em processos de "gentrificação" 54 de áreas degradadas. Na periferia do capitalismo, esses fenômenos de destituição da calçada pela autovia, que rasga o tecido urbano, são ainda

\footnotetext{
${ }^{52}$ Cf. Nobre (2010, p. 59). Vale também dizer que a situação das redes ferroviária e metroviária só tem piorado. Apenas em 2011, o número de passageiros transportados por trens e metrô aumentou de 5,9 milhões para 7,1 milhões, sem uma modernização da malha compatível com tal incremento - o que levou o secretário estadual dos Transportes Metropolitanos a chamar de tsunami a elevação no número de passageiros (Folha de S.Paulo, 2012, p. A2). Ainda no que concerne aos índices de superlotação no transporte coletivo, a taxa de ocupação da Linha Vermelha do metrô nos horários de pico em 2011 era pouco superior a dos trens da CPTM em 2009: 9,8 passageiros em pé por metro quadrado (Amaral, 2011). Nos ônibus, já em 1983, a lotação média nos horários de pico era 6 passageiros por metro quadrado, segundo Vasconcelos (1999, p. 235), mas, apoiado em dados da Companhia de Engenharia de Tráfego (CET) desse mesmo ano, o autor chega a mencionar o caso de alguns veículos com 15 passageiros em pé por metro quadrado, o que parece fisicamente improvável. A título de comparação, a taxa média de ocupação em automóveis é 1,2 passageiros por veículo, segundo Adauto Martinez Filho, diretor de operações da CET (AU. Arquitetura e Urbanismo, 2012).

${ }^{53}$ Um último exemplo mais recente para ilustrar, contra todas as evidências de desacerto, a força do modelo rodoviarista na aplicação de recursos públicos em transportes refere-se aos 6,5 bilhões de reais destinados à construção do Rodoanel Norte, que margeará a Serra da Cantareira, ligando as rodovias Airton Senna, Dutra, Fernão Dias e Bandeirantes. Além do custo financeiro, que permitiria construir 35 km de metrô (entre 2007 e 2009, o governo estadual estendeu a malha em apenas 4,7 km), tal obra, que contraria o artigo 82, inciso II, do Plano Diretor do município (determinando a priorização do transporte público sobre o individual) e também os percentuais orçamentários para transporte coletivo previstos no Plano Integrado de Transportes Urbanos (PITU 2025), destruirá a Serra da Cantareira, área de proteção ambiental tombada pelo Conselho Municipal de Preservação do Patrimônio Histório, Cultural e Ambiental da Cidade de São Paulo (Conpresp), pelo Conselho de Defesa do Patrimônio Histórico, Arqueológico, Artístico e Turístico (Condephaat) e pelo Instituto do Patrimônio Histórico e Artístico Nacional (Iphan), e desalojará mais de 2 mil famílias que, morando em casas sem escritura do terreno, serão pifiamente indenizadas. Ver Vier (2011).

${ }^{54} \mathrm{O}$ termo refere-se aos processos de "requalificação" do espaço urbano, em geral comprometidos com práticas violentas de segregação da pobreza.
} 
mais agravados pela falta de fiscalização no uso do solo, pela construção à margem da legislação urbanística, pela destinação de recursos públicos em desacordo com as necessidades da maioria da população e pela desigualdade brutal nos índices de mobilidade, determinada pelo nível de renda. ${ }^{55}$ Embora essa situação esteja se alterando com o incipiente declínio da cultura do carro $^{56}$ e com a percepção de que o direito à cidade não pode ser bloqueado por uma lógica do transporte como circulação de valor (donde a compreensão do direito ao transporte como direito social ${ }^{57}$ ), o reflexo disso na transformação do espaço urbano desfigurado por décadas de "carrolatria" ainda tem um longo caminho a percorrer.

Aceleração paralisante das urbes midializadas, bunkerização das elites, guetificação dos pobres, destruição da rua pela autopista... Muitas são as dimensões em jogo nessa complexa combinação entre fluidez e paralisia. Elas determinam uma lógica circulatória bem diversa daquela que nos habituamos a identificar na poesia urbana moderna, a qual ainda dava espaço a encontros fortuitos e à flânerie baudelairiana. Nessa nova lógica, em que os espaços públicos adquirem estatuto residual, constituindo uma espécie de intervalo intransitável entre ambientes privados, especialmente dramático é o destino da calçada. Tradicionalmente oferecendo acolhida para aqueles que tudo perderam (desempregados, loucos, mendigos, vagabundos de toda sorte, "ciscos" que encontravam pouso no olho da rua), também a calçada sucumbiu à mobilidade compulsória do "circulando, circulando", divisa que aparece no discurso das políticas públicas voltadas para a segurança e preservação do patrimônio, nas ações da Guarda Civil Metropolitana e dos demais "zeladores" da rua, encarnando-se ainda na arquitetura antimendigo, em franca proliferação na selva das cidades.

\footnotetext{
${ }^{55} \mathrm{Em} 2007$, o índice total de mobilidade para a faixa com renda familiar até 760 reais era de 1,53 viagens por habitante contra 2,69 para a faixa com renda superior a 5700 reais (Metrô, 2008).

${ }^{56}$ Nos Estados Unidos, país das autoestradas, o número de jovens que não dirigem dobrou nos últimos trinta anos, e a população de Detroit, polo da indústria automotiva, encolheu de 1 milhão e 800 mil pessoas, nos anos 1970, para atuais 700 mil (Lores, 2013).

${ }^{57}$ Veja-se a esse propósito a PEC 90/2011, da deputada federal Luiza Erundina, que propõe uma alteração no artigo $6^{\circ}$ da Contituição a fim de incluir, entre os direitos sociais (à educação, à moradia, à segurança, à saúde, ao trabalho, à segurança etc.), o direito ao transporte, condição de acesso aos demais. Tal proposta demonstra a sintonia da ex-prefeita com as ideias de Lúcio Gregori, seu secretário de Transportes entre 1990 e 1992, que, nessa época, já defendia a ideia de que o pagamento do serviço de transporte coletivo deveria ser indireto, através de impostos e taxas do município. Batizado com o nome de "Tarifa Zero", o projeto não chegou a ser implantado, pois a Câmara Municipal nem sequer votou a reforma tributária que o viabilizaria. Entre as razões para tanto, Gregori aponta, entre outras, a visão do transporte coletivo como negócio, o uso eleitoreiro da tarifa como elemento de barganha política e a introjeção, por parte dos trabalhadores, da ideia de que o deslocamento pela cidade é responsabilidade deles, mesmo dos que andam a pé por não conseguir arcar com a tarifa e para os quais a catraca constitui forte símbolo de humilhação (Gregori, 2010). Mais recentemente, tais ideias vêm sendo retomadas pelo Movimento Passe Livre, que também levanta a bandeira do transporte coletivo como direito social, ocupando as ruas e bloqueando os fluxos da cidade a fim de possibilitar a sua retomada (Movimento Passe Livre, 2013).
} 
Tal divisa, segundo Jean-Paul Maulpoix, leva ao desconcerto do flâneur pós-moderno, que, contradizendo Pascal, não encontra o centro em parte alguma e é

[...] o tempo todo reenviado às margens da cidade, como um lutador de box arremessado às cordas. Periferia por toda parte, só periferia, pois tudo é periférico. O retorno é infinito, ele dura todo o tempo da vida de um homem. Nada de sentido então, mas de zigue-zagues, nada de alegoria [...] "Circulando, não há nada para ver”: eis a palavra do fim. (Maulpoix, 2002, p. 81)

"Circulando, circulando": quando a exigência de mobilidade se transfere do âmbito econômico para os espaços públicos, "todo corpo inerte se torna suspeito", afirma Alban Lécuyer (Lécuyer, Rousseau e Paté, 2011, p. 6). Em tempos de “disneylandização" espaços públicos e aparição de centros lúdico-comerciais onde é preciso circular para consumir, os corpos imóveis dos que nada podem comprar tendem a desaparecer. O videomaker Giles Paté, no documentário Le Repos du fakir [O descanso do faquir], fez um inventário dos dispositivos de repressão à imobilidade em uma cidade como Paris (muito semelhantes aos dispositivos antimendigos de São Paulo). Afirma Paté (Lécuyer, Rousseau e Paté, 2011, p. 7):

Le Repos du fakir esboça uma tipologia dos mobiliários anti-SDF [sans domicile fixe] parisienses, mas a observação dos espaços públicos da capital vale para todas as cidades onde essa concepção de espaço público se dissemina. A gestão tecnocrática considera os corpos como objetos que perturbam a regulação dos fluxos. Os cidadãos são infantilizados, agredidos por esses dispositivos antiergonômicos que visam enxotar os sem-teto dos espaços públicos, atingindo, porém, todos os cidadãos. O espaço é assim degradado e deixa de ser um espaço partilhado.

Esses mobiliários projetados para ficar invisíveis em meio à cenografia urbana frequentemente se associam, no discurso dos administradores do espaço público, a justificações ideológicas que imputam aos sem-teto o desejo de usar os espaços públicos de

\footnotetext{
${ }^{58}$ O termo “disneylandização" é tomado de empréstimo a Jean-Pierre Garnier (2008). Apud Lécuyer, Rousseau e Paté (2011, p. 7).
} 
modo privado, transformando-os em casa, ao mesmo tempo que silenciam sobre as privatizações efetivamente perpetradas por aqueles que, atropelando a legislação urbanística, cercam praças, fecham ruas e se apropriam de áreas destinadas ao uso coletivo.

Assim temos, de um lado, esses expedientes de repressão da imobilidade (ligados à "rehaussmanização" generalizada das cidades, levada a cabo a partir da voga neoliberal dos anos 1980), de outro, a promoção desigual da circulação, que distingue entre uma suposta "boa circulação", ligada ao consumo, ao turismo, ao transporte de mercadorias e trabalhadores qualificados, e a "má circulação", de imigrantes pobres, desempregados, delinquentes. Nota-se então como alguns segmentos da sociedade são alvo de solicitações contraditórias, que, ao mesmo tempo, lhes proíbem a imobilidade e dificultam a circulação.

Tendo em vista tal contexto, voltemos à poesia, a fim de examinar algumas figuras dessa complexa lógica circulatória. A ideia é rastrear os dilemas da mobilidade em poemas que enfeixam várias formas de transporte, explorando também a percepção do espaço, a memória da cidade e da paisagem, as tensões no plano da sociabilidade, entre outras questões.

Comecemos então com a análise de alguns poemas de Alberto Martins reunidos em publicação recente intitulada, não por acaso, Em trânsito (2010).

\section{Mobilidade e trabalho na poesia de Alberto Martins}

A mais recente coletânea de poemas publicada por Alberto Martins explora de modo sistemático as relações entre mobilidade urbana e trabalho, mobilidade e memória, circulação e propriedade - razão pela qual interessa de perto à discussão aqui empreendida. O título do livro é o mesmo utilizado em uma exposição de 2007, retrospectiva que reunia a produção gráfica e escultórica do autor ao longo de duas décadas. Em texto para o catálogo dessa exposição, Guilherme Wisnik (2007) se vale da ideia de trânsito para entender o

próprio percurso criativo de Martins como um artista entre a poesia e as artes plásticas (e, no âmbito da gravura, entre o abstrato e "certo figurativo"), acolhendo a mobilidade como denominador comum entre as artes a que ele se dedica. 
[...] a mobilidade não é apenas um tema abordado formalmente na sua obra, mas o próprio motor criativo que a põe em funcionamento. Princípio que reflete uma compreensão estrutural da natureza mercurial das duas artes, já que a gravura assim como o texto impresso - é o suporte multiplicável, e portanto circulante, de uma matriz única. (Wisnik, 2007, p. 14)

A percepção desse princípio comum já havia sido formulada anos antes em um depoimento do próprio Martins ao se referir à base tipográfica como estrutura "real e imaginária” que dá materialidade à gravura e é “intrínseca ao escrever” (Martins, 2004, p. 211). Tal aproximação entre transporte, escrita e inscrição também se ligava, àquela altura, no princípio da década passada, ao "desrecalque do figurativo" na gravura, após um período marcado pela abstração geometrizante - o que corresponderia, nos poemas ilustrados de Cais (2002), à passagem de uma poesia de tipo mais sentencioso, impessoal, abstrato, marcado pelo jogo entre erosão e memória, pelo atrito entre luz e pedra, do livro de estreia, Poemas (1990), para uma escrita lastreada pela experiência da paisagem (a Serra do Mar, o porto de Santos) como lugar inaugural, sítio que articula memórias familiares (o luto pela figura paterna), a história nacional, novo-mundista, relatos de viajantes, diálogos com outros poetas, como Rimbaud, etc. (Weintraub, 2002).

Wisnik (2007) procura relacionar certos "motivos obsedantes" da poesia de Cais - o interesse por processos formativos lentos e graduais (sedimentação, calcificação), em oposição aos contrastes acentuados (ligados à busca de uma nitidez acerada, de matriz cabralina), bem como a abundância de imagens associadas ao lodo, à água, ao mangue - à presença de sujeiras, zonas de contato e infiltração nas gravuras que os acompanham. O crítico reconhece aí certo amadurecimento formal, o qual ele tributa ao lastro oferecido por uma paisagem concreta que, ao mesmo tempo, traz para as gravuras o tema das trocas sem lastro, das aparições da forma-mercadoria desterritorializada (referindo-se, sobretudo, à série de caixas e engradados). Porém a morosidade no movimento dessa forma, entregue a inércias e suspensões, seria também característica "da experiência brasileira, ou sul-americana, da paisagem e do território" - o que se evidencia ainda nas esculturas articuladas de Martins, cujo movimento é tolhido pelo peso.

Assim, nesse artista, a mobilidade tipográfica da escrita e da gravura não se deteria na fetichização do próprio fazer, não derivaria para a autonomia dos jogos metalinguísticos 
autônomos, pois nela o lastro (mesmo aquele fornecido pelas fantasmagorias do comércio) torna o trânsito transitivo. (Wisnik, 2007, p. 23)

É preciso levar em conta todos esses nexos entre circulação e memória (registro/escrita/inscrição), lastro e lentidão (e caráter nacional), transporte e transitividade, sem, no entanto ampliar demais o nosso foco a ponto de perder de vista o problema da circulação humana no espaço concreto da cidade. Se em Cais (bem como nas gravuras contemporâneas dos poemas nele reunidos) a mobilidade está mais circunscrita à experiência de uma paisagem específica, onde as coisas "ancoram e demoram" em uma suspensão cheia de ressonâncias míticas, históricas e familiares, os poemas de Em trânsito parecem se ocupar menos da paisagem que dos percursos parciais, dos trajetos repetidos ao longo dos trilhos, "a caminho do trabalho" (título da seção inicial da coletânea), a caminho da padaria, de volta para casa; as travessias breves ou longas, as sondagens noturnas, imaginação adentro. Os versos vão na cola dos passantes e transeuntes, dos trânsfugas (termos que dão título a poemas), às voltas com questões como "Que marcas tais percursos deixam nas calçadas?”, “O que grava a cidade em nós?”, “A quem ela pertence?”, “O que se perde ou ganha nas cadeias produtivas ou fora delas?”. Essa mudança no estatuto dos trânsitos permite também um aprofundamento da articulação entre as dimensões subjetiva e pública em jogo nessa poesia, conforme explica o próprio autor:

A literatura é um meio de transporte. Ela nos move, em vários sentidos, nos leva a distintos lugares e condições da realidade. O livro, por exemplo, tem muitos pontos em comum com o transporte público. Ambos reúnem a dimensão íntima do destino individual (Aonde eu quero ir? Em que estação quero descer?) e a dimensão coletiva, pois aquele veículo não existe em função de um único indivíduo, mas sim como uma necessidade coletiva. [...] O destino da literatura está diretamente vinculado à possibilidade de uma rede de transportes públicos digna, decente, que torne possível o livre trânsito da população. (Martins, 2007, p. 5$)^{59}$

\footnotetext{
${ }^{59}$ A articulação entre intimidade e destino coletivo vem sendo construída desde há muito na consciência do artista, encontrando equivalências também em sua maneira de encarar a obra de outros gravadores. Por exemplo, comentando o trabalho de Evandro Carlos Jardim, de quem foi aluno, Martins o descreve como gravador flâneur, que "conjuga, em seu perambular, espaço interior (do sujeito lírico) e destino coletivo (espaço da cidade)", que "não se coloca no ponto de vista do planejador urbano - que deseja e planeja a intervenção e com quem o artista moderno se identificou -, mas sim no do transeunte que em seu percurso diário transporta a cidade de um lado para o outro e a experimenta na própria pele". Esse ponto de vista que percorre o espaço urbano "do ângulo de baixo", ainda
} 
Desde o poema-epígrafe, dirigido ao leitor comum, "anônimo, pedestre/ modesto passageiro de seu tempo// [...] que neste mundo engarrafado/ usa o poema como meio de transporte", Em trânsito parece buscar essa perspectiva pedestre e pública de observação dos espaços urbanos, atenta ao esforço necessário para vencer distâncias, pois aqui a mobilidade é indissociável da dimensão do trabalho.

O livro divide-se em três seções. A primeira, "A caminho do trabalho", concentra-se justamente nos percursos de obrigação, no contraste entre faina e devaneio, entre a noite onírica ou insone e especulativa ("Noite no apartamento", p. 19; "Apartamento na noite", p. 20; "Vira-lata na madrugada", p. 23) e o dia industrioso e amortecedor, dia que despede a paisagem - "dar adeus a esse dia azul" ("Working day", p. 35); "eu observo as nuvens// [...] eu ignoro/ o que se passa com elas/ quando viro as costas/ a caminho do trabalho" ("Maio de tarde", p. 44) -, oblitera a percepção e a linguagem - "o dia transcorre// [...] enquanto alguma coisa/ feroz/ funda/ e imprecisa/ foge -// sem que eu consiga/ apanhá-la pelo nome ("Poema sem nome", p. 38) -, mas que também é atravessado por pausas epifânicas para o café, por ímpetos demissionários contrapostos à identificação compassiva com o trabalho (precário ou desvalorizado) dos homens-sanduíche e dos revisores ${ }^{60}$ e por repentes líricos como o da inveja das paineiras que se desvencilham dos fardos de algodão "sem aviso prévio" ("A caminho do trabalho", p. 46).

A segunda seção, intitulada "Inscrições", retoma os paradoxos dos trânsitos "não transitórios" (isto é, movimentos que, à força de se repetirem, deixam marcas de nossa passagem na cidade e da cidade em nós), deslocando a relação entre memória e mobilidade para um plano temporal e geográfico mais dilatado. Os registros aqui remetem à paleontologia, a fósseis e a estrelas, ao passado do Brasil (Anchieta) e da Europa, à história da arte nos campos da gravura (Hiroshige, Dürer) e da imprensa, da fotografia (Rodchenko, Capa), da poesia (Horácio, Vallejo, Áttila József), entre outras coisas. Trata-se de uma espécie de interregno no livro, um hiato temporal entre a primeira e a última seção, cujo foco se concentra de modo predominante no presente e no espaço geográfico da cidade de

segundo Martins, encerraria grande potencial crítico em um contexto “em que as intervenções urbanas, resguardadas raríssimas exceções, não escondem seu viés autoritário e costumam ser feitas de cima para baixo" (Martins, 2005, p. 52 e 54).

${ }^{60}$ A identificação se evidencia mesmo no caso de trabalhos mais prestigiosos, como o de editor, metaforicamente equiparado ao de lavrador ("Não trabalha no campo/ mas tem as mãos escalavradas:/ a pele dos dedos descama feito pergaminho", versos de "O editor", p. 45). 
São Paulo, reconhecível por meio de alguns topônimos. Em certa medida, trata-se de uma seção próxima dos poemas recolhidos em Cais, pela adoção de uma visada histórica mais ampla. No entanto, ao mesmo tempo, concentrando-se na questão do registro, que ultrapassa o contexto "geoepocal" e nos torna contemporâneos do mais distante (de Horácio, em um poema recitado por Flávio Di Giorgi ${ }^{61}$, da constelação do Cruzeiro, “contemporâneo dos meus ossos", p.55), evidencia-se aqui, sobretudo nos poemas sobre gravadores, fotógrafos, poetas e artesãos anônimos, a dimensão pública da arte. Assim é que na casa do pintor Apeles, não havia pintura no reboco ("a arte/ estava a serviço da cidade/ e o pintor era um bem comum/ de toda a terra", p. 59), da mesma forma que a pobreza de Hiroshige e Dürer atestava o privilégio por eles dado aos interesses da cidade e a descoberta da forma por Rodchenko em tempos revolucionários "era fruto/ do trabalho comum - e o trabalho comum/ uma alegria de todos" (p. 71).

Esses poemas, além de se somarem às imagens do trabalho "alienado" da primeira seção e de enfatizarem a centralidade do vínculo entre intimidade e esfera pública, também retomam a associação entre resistência e mobilidade, posta em relevo desde o primeiro poema do livro, "Estação Pinheiros" (p. 13), em que passageiros prestes a partir observam o trabalho da draga desassoreando o rio. ${ }^{62}$ É como se o deslocamento dos próprios passageiros dependesse da "carga revolvida" no fundo do canal, como se a fluidez só se estabelecesse graças ao trabalho sobre essa resistência oposta pela cidade, pela natureza e por outros homens. Tal articulação entre deslizamento e resistência atravessará o livro de ponta a ponta.

Assim, ainda nessa segunda seção, o tema da resistência vai aparecer principalmente no díptico "Na oficina", sobre o custo corporal e a contraparte de paralisia do gesto criativo ("para uma boa sessão de trabalho/ vários dias parado", p. 69) e sobre o contraste de resistências entre a alma da madeira e a da carne ("Na oficina II", p. 70). Assim, a dimensão pública e às vezes anônima da arte conecta-se com a experiência dessas resistências e com certa mística do trabalho manual, por exemplo, no poema que encerra a seção. Nele, o livro é parido no útero da gráfica, destacando-se a importância das mãos em

\footnotetext{
61 "Na padaria com Flávio Di Giorgi", p. 60. O poema sobrepõe o frescor da antiguidade entoada pelo professor ao tema do próprio poema de Horácio. O júbilo do poeta romano bebendo "o vinho de sua infância" equipara-se, pois, ao de Flávio, relembrando-o enquanto toma café na padaria.

${ }^{62}$ Draga, lodo e carga certamente evocam os guindastes e suspensões de Cais, mas aqui funcionam mais como pano de fundo e condição de possibilidade para outros movimentos e travessias no coração da urbe.
} 
meio ao trabalho mecanizado, mãos que "como parteiras livram a passagem/ da morte à vida" (p. 78).

Por fim, na terceira seção, que dá título ao livro, há uma volta ao presente e a retomada de algumas das questões postas nas seções anteriores. Vemos aqui também poemas sobre o contraponto entre as errâncias diurnas e noturnas (vários poemas sobre insônia), sobre os percursos invisíveis que sustentam a vida citadina (o trajeto do lixo e o da lenha que alimenta os fornos da cidade), sobre as interrupções no fluxo de trabalho que não estancam as dívidas do alfaiate ("A noite de insônia do alfaiate endividado", p. 91) e obrigam os operários da construção civil a "passar um tempo no sol/ um tempo na sombra" ("No canteiro de obras", p. 96).

As imagens de bloqueio/obstrução do trabalho e do espaço, das vias de passagem são usadas para figurar tanto a fragilidade dos que vendem sua força no mercado como as forças de acumulação do capital, as quais ordenam a produção do espaço urbano construindo eclusas que impedem "a graça da água em fuga" ("Sobre a arte do negócio", p. 95), faturando com o tráfego nas marginais ("Reflexões no trânsito", p. 97) e mantendo lotes urbanos ociosos com fins especulativos, conforme se vê em "Observações à mesa de trabalho" (p. 99). Esse último poema compara a mesa arrumada "entre um trabalho e outro" ao mato queimado no terreno vizinho, guardado pelo proprietário "para alguma operação imobiliária". A comparação é curiosa, pois justapõe o uso produtivo da mesa ao uso improdutivo do solo, em prol do aumento da renda fundiária. Aqui como em outros momentos do livro, o bloqueio se liga à repetição ("por quanto tempo permanecerá assim/ o mato crescendo e sendo queimado/ crescendo e sendo queimado"), a um movimento que se repete por incapaz de se completar, de passar a outro estágio, de converter o trânsito em viagem $^{63}$, o que configura uma espécie de mobilidade imóvel. Não por acaso, esse bloqueio ditado pelos imperativos da acumulação, no livro, vem espelhado com outro poema sobre a prodigalidade dissipadora do artista que joga no papel tudo o que tem ("um tampo de mesa

\footnotetext{
${ }^{63}$ Segundo De Felice (2009, p. 79), o trânsito, ao contrário da viagem, não representa progresso nem regressão, mas uma passagem “do mesmo ao mesmo", do presente ao presente. Referindo-se ao turismo no período pós-guerra, Siegfried Kracauer também alude à banalização do exótico e à redução da viagem a mera "troca transitória de estadia". Escreve ele: "Quanto mais o mundo, graças ao automóvel, ao cinema, ao avião se encolhe, tanto mais o conceito de exótico torna-se relativo [...] Graças às vantagens da civilização são praticamente ínfimas as partes da superfície terrestre que se podem chamar ainda de terra incógnita, os homens se sentem em casa em toda parte, em seu país ou em qualquer lugar - ou não se sentem em casa em lugar nenhum. [...] A ênfase cai sobre o desligamento enquanto tal que a viagem oferece e não sobre o interesse que se procura neste ou noutro lugar” (Kracauer, 2009, p. 82).
} 
sem limites/ e os ruídos (inaudíveis)/ da cidade", p. 98), alegrando-se com sua "reserva de pobreza".

O motivo do bloqueio por repetição, verdadeira pena de Sísifo, reaparece ainda uma vez na segunda parte do poema "Na véspera da mudança" (p. 104), que fala de um sonho com uma casa "construída pela metade” ("a outra metade/ eu construía/ e pegava fogo/ construía/ e pegava fogo").

Sem embargo, a fim de melhor compreender a intrincada teia de relações entre cidade, trabalho e mobilidade estabelecida por Alberto Martins, cumpre analisar mais detidamente um poema para o qual parecem convergir várias linhas de força do livro.

\title{
POVO ERRANTE
}

\author{
$\mathrm{Na}$ esquina do farol \\ o menino me empurra \\ duas balas por um real. \\ Dou a nota \\ mas digo para guardar as balas. \\ Ele insiste \\ - pega a bala, doutor - \\ quer completar a transação. \\ O sinal continua fechado. \\ Pergunto seu nome. \\ Moisés. \\ Aquele mesmo \\ diante de quem um dia \\ se abriu o mar vermelho.
}

(Em trânsito, 2010, p. 101)

O poema retoma uma cena familiar no cotidiano das cidades: um flash do trabalho desses ambulantes, adultos ou crianças, que se aproveitam da parada imposta pelo semáforo para vender, ou melhor, empurrar, balas, garrafas d'água, flores e outras mercadorias de baixo valor aos motoristas que aguardam impacientemente o sinal verde. Não há menção explícita ao carro ${ }^{64}$, depreendido, no entanto, do contexto.

\footnotetext{
${ }^{64}$ Vale dizer que o meio de transporte predominante nos poemas são os pés, o trem e o metrô, o que se coaduna com a identificação com o "anônimo, pedestre" da epígrafe e com os modos coletivos de transporte, cujo caráter público os versos almejam assimilar. Salvo engano, em 69 poemas, o "narrador" aparece em posição de motorista apenas nesse poema e em "Reflexões no trânsito", surgindo também como elemento de cena em "São Paulo: 19:45" e "Passantes". Neste último, o carro é apenas aludido por meio dos faróis que "arremessam" contra o muro (imagem inusitada e violenta) a sombra do homem atravessando a rua. A respeito do impacto do automóvel
} 
A situação de encontro promovido pelo "impasse cinético" do sinal fechado é sobreposta à transação comercial, que não se completa diante da recusa do motorista em levar as balas. A circulação do dinheiro sem a contraparte da mercadoria descaracteriza a venda, degrada a operação em esmola e fixa o menino na posição de pedinte, o que já estava de certo modo anunciado na escolha do verbo "empurrar" para definir a ação da criança, indicando coação do motorista "doutor", obrigado a comprar coisas que não deseja ou de que não precisa. A assimetria de classe sinalizada pela diferença nos meios de transporte (menino pedestre $\times$ adulto motorizado) é reforçada pela transação defeituosa, incompleta.

A ambiguidade entre venda e esmola, comércio e caridade é um traço importante da vida metropolitana que recentemente vem ocupando a atenção de sociólogos e urbanistas. Ela se liga ao que Telles e Hirata chamam de "mobilidades urbanas laterais", isto é, ao "trânsito" de trabalhadores perdidos entre "o trabalho precário, o emprego temporário e os expedientes de sobrevivência e as atividades ilegais, clandestinas ou delituosas" (Telles e Hirata, 2011, p. 375). Essas mobilidades laterais e ambíguas parecem produzir um complexo de efeitos morais e psicológicos que vale a pena investigar. Em "Povo errante", por exemplo, destaca-se a atitude do vendedor ambulante cujo comportamento extrapola a motivação econômica, segundo a qual receber o dinheiro e conservar a mercadoria seria mais vantajoso. Mas a transação bloqueada tem alto custo psicológico, custo talvez correspondente ao ganho de quem dá a esmola, aplacando a possível culpa de classe e "pagando" imaginariamente a dívida social.

Poema recente de Francisco Alvim descreve cena muito semelhante no que se refere a esse ganho implícito:

\section{ACONTECIMENTO}

$$
\text { para Roberto }
$$

Quando estou distraído no semáforo

e me pedem esmola

me acontece agradecer

(O metro nenhum, 2011, p. 13)

sobre as outras formas de deslocamento pela cidade, em poemas de Ana Cristina Cesar, José Paulo Paes e Sebastião Uchoa Leite, ver Bosi (2010). 
A distração aqui é, em verdade, atenção redobrada, que, intuindo lucro na doação, desloca a gratidão do pedinte para o benfeitor, talvez também servindo como compensação para o pudor de quem faz caridade em vez de justiça.

Ainda com relação à ambiguidade entre comércio e esmola, lembro-me de um poema de Tarso de Melo da coletânea Lugar algum (2007, p. 63). Nele (o último da seção intitulada "Por nada") descreve-se a situação de um pedinte que consegue amealhar algumas moedas expondo a perna doente na via pública. A perna disputa a atenção com as vitrines, despontando ela também como uma "mercadoria estranha/ que ninguém recolhe". De certa maneira, esse poema representa a contraface da ambiguidade presente em "Povo errante": se em Martins o trabalho se degrada em esmola, em Melo a esmola integra-se ao mundo do comércio, competindo com outras mercadorias e sendo observada por uma criança "logo engolida pelas sacolas/ com que divide a mão/ de sua mãe". ${ }^{65}$

No entanto, em "Povo errante", o bloqueio cinético e comercial ainda se desdobra temporalmente na evocação de um episódio bíblico do Êxodo. O nome do menino vendedor de balas coincide com o do profeta judeu que guiou seu povo escravizado para fora do cativeiro egípcio - e o vermelho do sinal fechado se liga metonimicamente ao nome do mar cujas águas tiveram de se abrir.

A sobreposição de tempos históricos é um recurso presente em outros poemas do livro - por exemplo, “São Paulo: 19:45” (p. 103), no qual também um nome, Pompeia, conecta o bairro paulistano à cidade romana destruída pela erupção do Vesúvio. Em "Povo errante", porém, a sincronia parece mais fortemente motivada, determinada por vários elementos: o nome, a cor, a condição erradia e escravizada de um povo e de uma classe. O menino que "quer completar a transação" também se encontra sob o cativeiro da caridade e do trabalho ilegal, e precisa empreender a travessia (quem sabe rumo a que deserto, talvez sem a ilusão de nenhuma Terra Prometida - à qual, aliás, o xará bíblico tampouco chega).

O desfecho do poema não resolve o impasse: ele não diz se o motorista aceitou as balas, se a transação se completou antes de o sinal abrir, conservando-se, portanto, nesse limiar carregado de tensões.

${ }^{65}$ O fecho do poema é bastante hábil ao estender o princípio da "mercadorização" a tudo, inclusive à criança, que disputa a mão da mãe com as sacolas como a perna disputa a atenção com as demais mercadorias. 
Algo na composição faz também lembrar a célebre canção "Sinal fechado", composta por Paulinho da Viola em 1969, regravada por Chico Buarque, em LP homônimo, de 1974. Escrita em um dos piores momentos da ditadura militar, logo após a promulgação do Ato Institucional no 5 (AI-5), a canção flagra o desencontro entre dois amigos que o sinal fechado aproxima sem reunir. No diálogo todo vazado em frases-clichê, avulta a urgência de dizer algo que "foge à lembrança" e desaparece "na poeira das ruas", sob o látego da pressa, "alma dos negócios". Testemunho de outros fechamentos ligados à circunstância histórica em que foi composta, tal música marca um momento de aceleração urbana, ditada pelo açodamento desenvolvimentista, que separa os amigos e detém o diálogo no nível fático, poeticamente trabalhado. O sonho de um "lugar no futuro", mais plausível à época, alimenta o bloqueio na canção, que não explora assimetrias de classe, reproduzindo as falas de interlocutores de igual condição, ambos motorizados. "Povo errante", em contrapartida, explora essa assimetria como um componente do bloqueio, filtra a narração da perspectiva do interlocutor motorizado, que refere a expectativa de superação não a um "lugar no futuro", mas no passado, um passado mítico, bíblico, talvez irrecuperável.

A imagem do inconcluso/bloqueado em diferentes situações de classe também aparece em outro poema, extraído da primeira seção do livro:

\section{WORK IN PROGRESS}

em cima da mesa

muitas coisas permanecem

inconclusas

uma xícara de café

e aquele homem em pé

à beira do viaduto

(Em trânsito, 2010, p. 39)

Como em "Observações à mesa de trabalho", em que o espaço da mesa é equiparado a um lote de terra, a mesa aqui funciona como um diagrama da cidade (como a imago mundi em talismãs antigos): o que nela jaz inconcluso remete a outros bloqueios, como o do homem estacado à beira do viaduto. Louco, mendigo ou desempregado, sua 
mobilidade é economicamente regulada e afeta a mobilidade dos demais concidadãos. $\mathrm{O}$ in progress aqui não deixa de ter ressonância irônica, indicando menos a aproximação a alguma espécie de término ou resolução formal que o travamento da obra e a injustiça, a falta de oportunidades que fixam o homem à beira do caminho.

Assim, vemos como o nexo entre trabalho, memória e mobilidade constela todo o livro e define tanto as várias possibilidades de circulação como os bloqueios e aporias da vida urbana. A perspectiva de observação presente em vários poemas, mesmo quando se percorre o espaço urbano "do ângulo de baixo", expressão cunhada por Martins para descrever os percursos do gravador flâneur Evandro Carlos Jardim, atesta o lugar ambíguo do artista/intelectual, que se identifica e solidariza com os socialmente pequenos, como o homem à beira do viaduto e o lavrador de mãos escalavradas (como as do editor), sem perder de vista a própria condição de "doutor" (“pega a bala, doutor”) e a proximidade com os donos da cidade (conforme vemos em “Observações à mesa de trabalho"). É de perguntar se tal ambiguidade não abranda o gume crítico da indignação patente em certas passagens e liricamente associada a um vago desejo de mudança - "preciso urgentemente/ de outra geografia” (p. 106), “ainda não fiz cinquenta anos/ dá tempo de mudar alguma coisa" (p. 109), lê-se ao final dos dois últimos poemas do livro -, desejo que talvez subestime o peso dos bloqueios internos na dificultação das travessias.

Mas prossigamos na investigação sobre as imagens de circulação na poesia brasileira contemporânea debruçando-nos a seguir sobre imagens de encontro no transporte coletivo, tomando dessa vez como material de análise poemas de um conjunto de poetas. Interessar-nos-á especialmente o impacto subjetivo causado pela precarização do transporte público, decorrente de décadas de privilégio concedido ao transporte individual em nome da ideologia rodoviarista a que nos referimos de início.

\section{Encontros em movimento: intersubjetividade e circulação}

Os encontros no transporte coletivo constituem um capítulo à parte da sociabilidade urbana e envolvem aspectos psicológicos ligados à própria intensidade de estímulos em jogo no deslocamento pelos espaços da cidade. 
Em clássico ensaio de 1903, “A metrópole e a vida mental”, Georg Simmel (1858-1918) referiu-se à atitude blasé (reserva, impessoalidade, indiferença) como base dessa vida mental e defesa contra a intensidade da estimulação nervosa (mudanças súbitas, fortes contrastes) imposta pelo ambiente metropolitano: “A atitude blasé resulta em primeiro lugar dos estímulos contrastantes que, em rápidas mudanças e compreensão concentrada, são impostos aos nervos"(Simmel, 1979, p. 16).

Nesse contexto, a manutenção da estabilidade psíquica dependeria de certa impessoalidade/superficialidade (e até mesmo de certa antipatia ou prontidão para o antagonismo $^{66}$ ) que, ao mesmo tempo, favoreceria a promoção da subjetividade e o desenvolvimento do indivíduo em condições mais favoráveis do que as vigentes em cidades pequenas e no meio rural. Tais condições são impostas pela economia monetária, por meio da qual o indivíduo alcança tudo o de que precisa sem ter de estreitar contato com os demais cidadãos. Submetido à divisão social do trabalho, ele desfruta de mais autonomia e liberdade, o que não se traduz necessariamente em maior conforto emocional.

Assim, os deslocamentos promovidos por meio do transporte coletivo, que prolongam o contato interpessoal em um espaço restrito, parecem enfatizar esse traço da psicologia urbana já que "a proximidade física e a estreiteza de espaço tornam a distância mental mais visível.” (Simmel, 1979, p. 20)

Não é possível, entretanto, nos contentarmos com qualquer tipo de generalização sobre a psicologia dos transportes coletivos, que são muito distintos uns dos outros e que agrupam os passageiros sob condições de modo algum equivalentes.

Tratando dessas diferenças fenomenológicas entre as várias modalidades de transporte coletivo, Pierre Sansot (2004) se refere, por exemplo, à oposição entre ônibus e metrô. Enquanto aquele conserva algo do padrão de sociabilidade burguesa, com razoável diferenciação entre funções e passageiros, neste há maior subtração da individualidade, em parte por causa do caráter viscoso da multidão que ele abriga e que é diferente da multidão da rua, pela qual é possível deslizar sem risco de cair ou de ser arrastado. Na multidão viscosa do metrô, ao contrário, as pessoas

\footnotetext{
66 "Uma antipatia latente e os estágios preparatórios do antagonismo prático efetuam as distâncias e aversões sem as quais esse modo de vida não poderia absolutamente ser mantido. [...] O que aparece no estilo metropolitano de vida como dissociação da realidade é apenas uma de suas formas elementares de socialização.” (Simmel, 1979, p. 16)
} 
[...] não cessam de reivindicar a diferença e se deixam privar do próprio rosto, do próprio sorriso, talvez do próprio sofrimento. Toda a gratuidade foi abolida, reina somente a Necessidade, o Trabalho. O olhar dos passageiros, mesmo quando leem, costuma tornar-se cego e, de toda maneira, eles não têm mais a liberdade impertinente, a vivacidade do homem que busca captar a diversidade movente do mundo que é seu domínio, como acontece, por exemplo, com os passageiros na plataforma de ônibus: os rostos não aspiram mais a honra de exprimir coisa alguma e aguardam voltar à superfície para reassumir suas formas habituais. (Sansot, 2004, p. 316-7) ${ }^{67}$

De todo modo, subsiste como traço comum aos deslocamentos coletivos motorizados uma experiência de alteridade bastante diversa da que nos oferecem os encontros pedestres (nos locais em que eles ainda podem de fato ocorrer, fora dos bunkers e demais espaços de segregação socioeconômica). A ela se refere a antropóloga Janice Caiafa (2007), estudiosa das viagens de ônibus em cidades como Rio de Janeiro e Nova York. Caiafa observa de que maneira o transporte coletivo oferece, por sua própria natureza, oportunidades de dessegregação virtualmente capazes de converter o contato com a variedade urbana em uma experiência de alteridade. Ele cria uma espécie de intervalo e aproxima desconhecidos que, afastados de sua vizinhança, de sua casa ou de seu local de trabalho, dividem por minutos ou horas um ambiente em movimento. Tal contato "dá fuga" em relação aos circuitos familiares, alarga os limites da percepção e é atravessado por uma série de tensões, vividas de modo mais defensivo ou criativo, conforme as diferentes configurações urbanas.

A seguir vamos, então, examinar algumas representações desse "encontro em movimento" em poemas sobre ônibus. A escolha dessa modalidade de transporte coletivo se deve em parte ao fato de o ônibus constituir uma espécie de cenário intermediário entre o ambiente privado, doméstico do automóvel ${ }^{68}$ e o caráter desidentificador e dessocializante do metrô - o que talvez assegure mais oportunidades de interação social.

\footnotetext{
${ }^{67}$ De Felice (2009, p. 186), atentando também para o potencial "anonimizador" do metrô, que ele designa de modo hiperbólico como "centrífuga de identidades", retira da observação uma conclusão totalmente absurda, referindo-se à deslocação nesse meio de transporte como um "exercício de pós-cidadania" pela experiência de um "habitar comunicativo da metropoleletrônica, no qual a mudança, a velocidade e a transformação tomam o lugar das identidades fixas e separadas arquitetonicamente, típicas das formas constitutivas de todas as cidades".

${ }^{68}$ Sobre o automóvel como extensão da casa (e dos valores privados) e sobre o vínculo entre tal domesticidade e o potencial acidentário dos automóveis, ver Giucci, Guilhermo (2005, p. 74 e seguintes).
} 
Contudo, antes de entrarmos na análise desses poemas, atentando especialmente para a ressonância subjetiva, inconsciente das tensões aí produzidas, gostaria de comentar brevemente, à guisa de contraponto, o célebre poema de Mário de Andrade "O bonde abre a viagem", publicado postumamente em Lira paulistana, de 1945. Mesmo se referindo a um meio de transporte que, tendo sido (ao lado dos trens) o principal modo de transporte coletivo em uma cidade como São Paulo, entrou em declínio a partir dos anos 1940 e desapareceu por completo em 1968 (Rolnik e Klintowitz, 2011, p. 92), é possível depreender do bonde andradino um fundo de normas de civilidade e trocas intersubjetivas cuja lembrança será útil na leitura dos poemas contemporâneos sobre transporte coletivo. Escreve Mário:

$\mathrm{O}$ bonde abre a viagem,

No banco ninguém

Estou só, stou sem.

Depois sobe um homem, No banco sentou,

Companheiro vou.

O bonde está cheio,

De novo porém

Não sou mais ninguém.

(Poesias completas, 1974, p. 285)

A estrutura formal é muito singela: três tercetos, em redondilha menor, com rimas entre o segundo e o terceiro versos e uso da mesma rima na primeira e na última estrofes. No plano do conteúdo (descrição de uma viagem de bonde), o trajeto é abstraído, assim como a paisagem e os próprios passageiros, que não se distinguem a não ser pela relação que o eu lírico estabelece com elas: companheiro único $\times$ multidão indiferente.

Tratando do tópos "bonde" na poesia de Mário de Andrade, Marlene de Castro Correia (2010) observa a singularidade de "O bonde abre a viagem". Enquanto em outros poemas dedicados ao tema Correia destaca a composição multifacetada da cidade pela olhar em movimento (que justapõe cinematograficamente elementos heterogêneos do entorno), aqui a descontextualização espaço-temporal sublinharia "a tensão individualidade/ totalidade, que implica, em seus vários desdobramentos, a vivência simbólica da 
individuação como culpa a ser redimida pela imersão e dissolução do eu no todo.” (Correia, 2010, p. 222). De toda maneira, vale dizer que a dissolução do eu na multidão, tema moderno por excelência, recorta-se nesses versos contra um fundo de civilidade e cortesia que, de certo modo, resguarda a reversibilidade entre as posições de "companheiro" e "ninguém".

Também a opção pelo ritmo regular da redondilha não parece casual. Ela talvez concorra para sugerir algo do próprio ritmo de deslocamento do bonde: ritmo confortável, humano, reconhecível. Três estrofes fazem esse percurso da solidão ao anonimato, mas no meio há o encontro, a curiosidade sobre esse outro que se senta a meu lado (diferença que é acentuada pela rima destoante em "ou", contraposta às rimas nasaladas das demais estrofes). Essa curiosidade e abertura para o outro lembra as redondilhas de um famoso anúncio publicitário, atribuído ao poeta pernambucano Bastos Tigre (1882-1957), veiculado em bondes de São Paulo e do Rio de Janeiro a partir de 1918:

Veja, ilustre passageiro,

O belo tipo faceiro

Que o senhor tem ao seu lado.

No entanto, acredite,

Quase morreu de bronquite:

Salvou-o o Rhum Creosotado.

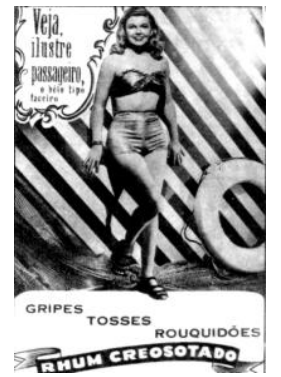

À parte a hipocrisia publicitária, o anúncio atesta uma situação em que os passageiros ainda podiam ser chamados de "ilustres" e em que, em certa medida, a contemplação interessada era possível, talvez mesmo até alguma espécie de solidariedade ou compaixão.

Tal padrão de civilidade deve ser levado em conta nas análises dos próximos poemas, nos quais, por força da precarização (grande número de passageiros por metro quadrado, frotas reduzidas, aumento no tempo de duração das viagens) a gentileza não parece subsistir senão sob forma residual.

A propósito dos ônibus franceses, Sansot também se refere a um arcabouço de gentileza, a um código de cortesia distante tanto dos procedimentos mais impessoais e midiatizados dos trens e metrôs como da selvageria automobilística. Refere-se ele a normas cuja solenidade comportaria até mesmo algo de fetiche, com fixação inconsciente no imaginário infantil (Sansot, 2004, p. 298-9). Ainda que essa gentileza soe nostálgica ficção 
e pouco tenha em comum com a situação dantesca do transporte coletivo flagrada nos poemas de nossa amostra, ela parece um componente fundamental a considerar na análise das tensões produzidas pelo encontro nos ônibus, mesmo quando nada mais resta daquela antiga atmosfera de um salão sobre rodas. ${ }^{69}$

Façamos então um salto no tempo a fim de verificar, na poesia brasileira atual, de que maneira se estabelecem o intercâmbio entre o eu e os outros e as defesas contra a superestimulação nas condições paradoxais de mobilidade a que nos referimos inicialmente.

Comecemos por um poema de Duda Machado, "Carapicuíba", escrito mais de meio século após a Lira paulistana de Mário.

\section{CARAPICUÍBA}

sentados

as cabeças caindo

uma a uma

o sono

resistindo aos freios

aos solavancos

do ônibus

em pé

compactados num híbrido

de cabeças e braços

que não permite

distinguir seus donos

se equilibram

vacilam

e obstinados

se agarram

ao silêncio:

último recurso

de espaço

(Margem de uma onda, 1997, p. 73)

${ }^{69}$ A equiparação entre a cortesia vigente nos ônibus e a sociabilidade burguesa de salão vem ainda de Sansot: "O interior do veículo recordava o salão: pedia-se à criança para sentar direito, para se comportar, ceder lugar aos mais velhos” (Sansot, 2004, p. 299). 
Como no bonde marioandradino, esses versos retomam a experiência do anonimato, a sensação de desaparecimento em meio à aglomeração. A mudança de foco, no entanto, da primeira para a terceira pessoa do singular, intensifica o processo de dissolvência e compactação dos passageiros "num híbrido/ de cabeças e braços/ que não permite/ distinguir seus donos". Para isso também concorrem o recurso ao sujeito indeterminado e o desenho sintático que acumula orações subordinadas adverbiais reduzidas de particípio e gerúndio. Esse acúmulo adia a entrada da oração principal ("se equilibram/ vacilam/ [...] se agarram”) em que, em uma leitura desatenta, o primeiro verbo ameaça compor sintagma com a última palavra do verso anterior ("seus donos se equilibram”). Tal confusão é reforçada pela supressão das maiúsculas e dos sinais de pontuação (com a única exceção dos dois pontos no antepenúltimo verso).

Não obstante, ao movimento de compactação parece opor-se, com uma pitada de humor melancólico, um tipo de resistência fragílima, porém inesperada: o silêncio. A surpresa advém justamente dessa conversão do vazio acústico em vazio espacial, sem que se desfaça a tensão inicial, associada às imagens de esgotamento e indiferenciação. O silêncio aqui separa de modo precário, instável, os corpos que a cidade compacta, funcionando, portanto, como índice das tensões urbanas.

No que se refere à equiparação entre som e espaço, vale dizer que ela atua em outros poemas de Margem de uma onda, como "Interferência" (p. 77-8), no qual, após o recolhimento de uma voz, subitamente surgida no meio da rua e sussurrada ao pé do ouvido, "o espaço se restaura,/ e dentro dele/ retomo meu caminho", e "Espaço com vozes" (p. 87-8), em que vozes “insinuavam uma existência além/ de seu próprio limite físico/ enquanto se deixavam/ traduzir no espaço/ [...] à imagem de nuvens tomadas/ pela ambição de fixar-se". São poemas ligados à questão fulcral do livro, a do conflito entre margem (forma/espaço/fixação) e onda (som/duração/movimento), é claro. Entretanto, à diferença de outros poemas, em que tal conflito é tratado em chave metalinguística, de modo abstrato, em "Carapicuíba" ele aparece muito concretamente em um poema sobre a periferização da pobreza e a precarização do transporte público.

Ainda no que tange à função exercida pelo silêncio nesse contexto, vale também lembrar a observação de Simmel (1979) sobre uma das principais novidades trazidas pelos trens e ônibus na Berlim do início do século XX: o fato de que, nesses veículos, pela 
primeira vez na história, as pessoas permaneciam por tempo prolongado em situação de contato visual intenso, mas sem se falar. Caiafa (2007, p. 108) conecta a observação de Simmel às teorias de Gabriel Tarde sobre a relação entre o silêncio e a intensidade conversacional nas grandes cidades. Nelas o silêncio não atuaria como uma interrupção comunicacional, antes constituiria uma modalização no fluxo das conversas que, ativamente produzido, serviria de defesa contra a indiscrição:

A conversação é a mãe da polidez. Isso acontece mesmo quando a polidez consiste em não conversar. Nada parece mais singular, mais antinatural a um provinciano chegado a Paris, do que ver os ônibus cheios de gente que se abstêm cuidadosamente de falar. (Tarde, 1992, p. 141, apud Caiafa, 2007, p. 108)

Trata-se, portanto, de um silêncio cultivado, que "se recorta sobre um fundo de grande estimulação material e afetiva - uma espécie de conversação por outros meios", pondera a autora (Caiafa, 2007, p. 108). Filho da polidez, gerado em um espaço público, em que a diversidade não foi obliterada pela violência ou pelo autismo, tal silêncio nada tem em comum com aquele outro, descrito no poema de Duda Machado, em que o valor defensivo sofreu uma ativação paroxística. ${ }^{70}$

Sem embargo, em face do fracasso dessa defesa, convém examinar de modo detido o que ocorre quando o fluxo de conversas não pode mais ser modalizado pelo silêncio. Passemos assim ao poema de outro autor, Tarso de Melo, por meio do qual é possível captar sinais de perigo no interior dessa rua semovente:
ASSUNTOS
"filho vira
pássaro e
voa", ele diz
um outro, curvo, esconde o riso
no rosto à mão

\footnotetext{
${ }^{70}$ No entanto, é preciso ressaltar a caducidade desse recurso à luz das condições sonoras atualmente vigentes nos veículos de transporte coletivo em uma cidade como São Paulo, onde, apesar da existência de uma lei (Lei 6.681, de 1965) proibindo o uso de aparelhos sonoros nesses veículos, é enorme o número de passageiros que se queixa do alto nível de ruído produzido por celulares usados como rádio, sem fones de ouvido, bem como por aparelhos de televisão com som. Ver Garcia (2009).
} 
o de barba, circuns-

pecto, observa

e conversa sozinho

ela: "não acredito

em filhadaputa

algum" e séria

toca a campainha

"tem que morrer", desembarcando

um que se levanta,

outro anuncia o assalto

ninguém se mexe

(Carbono, 2002, p. 72)

O poema costura estilhaços de conversa que convergem para a descrição de uma cena de assalto no ônibus. $\mathrm{O}$ curioso é que, embora tais fragmentos não componham propriamente um diálogo, os "assuntos" se sucedem conforme um encadeamento lógico que conecta a metáfora inicial do voo, signo da maior mobilidade, ao imperativo do verso final ("ninguém se mexe”), que aprisiona os passageiros no veículo em movimento.

Os falantes, apesar de não se interpelarem diretamente, parecem reagir uns aos outros: o primeiro esboça talvez um lamento contra a autonomia do filho, que provoca o riso encoberto do segundo, o solilóquio do terceiro e a saída abrupta da quarta que, expressando abruptamente seu ódio (“filhadaputa tem que morrer”) contra um alvo difícil de especificar, antecipa um desfecho possível para o assalto que se inicia. Tudo se desenrola rapidamente por meio de uma série de oposições - filho/“filhadaputa", voo/morte, riso/circunspecção, desembarque/paralisia - que testemunham o doloroso enlace entre violência e solidão.

Condições semelhantes às representadas no poema aparecem em depoimentos de usuários de ônibus na cidade do Rio de Janeiro colhidos e analisados por Caiafa (2002). No Rio, como em São Paulo, os ônibus constituem o principal meio de transporte urbano e a operação é feita por empresas privadas, que exploram de modo acintoso o rodoviário (impondo-lhe tempos de viagem impossíveis, maquinário adverso etc.). Tal exploração, 
somada ao problema da violência (calote, assalto, incêndio, acidente), à dificuldade de embarcar ou saltar, ao risco da queda (associado a um estilo de direção aos arrancos e em alta velocidade), entre outros perigos, engendra um clima bastante ruim que serve de moldura para as interações no interior do veículo.

Tratando especificamente do problema dos assaltos, Caiafa flagra uma série de acordos em que a forma mais usual de proteção diante do infrator é a indiferença pela sorte do outro, o eclipse da solidariedade.

Para evitar futuras retaliações, motoristas colocam em risco os passageiros dando carona a assaltantes ("carona da paz"), cobradores consentem no calote para não levar tiro (ou torcem para que o assalto só atinja os passageiros, deixando a salvo o dinheiro das passagens, que os patrões o obrigariam a repor ${ }^{71}$ ) e passageiros ignoram-se uns aos outros, dando as costas muitas vezes ao infortúnio de quem se encontra a dois bancos de distância. Forja-se uma espécie de cumplicidade na indiferença que não se abranda nem mesmo quando se reconhece a vacuidade desses estratagemas.

Voltando, porém, a Tarso de Melo, vale a pena frisar que o impasse entre circulação e paralisia, questão central deste capítulo, é recorrente ao longo da obra do autor, aparecendo, por exemplo, no poema "Sem saída" (p. 20), de Lugar algum (2007). Nele, contrariando a utopia viária da cidade sem atrito, a rua "não tem o que faz/ dela, como os carros gostam,/ via; retém/ tem memória/ barra, volve, encerra/ (martela, prensa, martela,/ o som toma as formas/ que forja)". O bloqueio ressurge em "Fila" (p. 28), do mesmo livro, poema em que o avanço, impedido, se estende da fila de pessoas à de carros e acaba, na contagem regressiva dos passos, emperrando tudo a sua volta - a brisa, o sol, as horas (que devem "trocar de posto" no "imenso relógio").

A paralisia associada ao transporte também aparece nos poemas em prosa de Planos de fuga (2005), o que ocorre de modo eloquente nos poemas 12 e 13 (p. 19-20). No primeiro, que alude à longa interdição das obras do Fura-Fila ${ }^{72}$ na capital paulista, multiplicam-se as figuras do entrave: “Aqui, mesmo os totens formam/ fila. As colunas. O

\footnotetext{
${ }^{71}$ Afirma um cobrador: "a gente dando o dinheiro [para o ladrão] não morre na mão dele, mas morre na mão do patrão. Só trabalha depois que pagar. Pode até registrar na delegacia que o patrão não vai aceitar”. (Caiafa, 2002, p. 78)

72 "O Fura-Fila foi apresentado como proposta eleitoreira de Celso Pitta, em 1996. Seria um trem futurista que percorreria um trajeto de 125 quilômetros. Eleito, Pitta pouco fez para colocá-lo em prática - mas enterrou 270 milhões de reais na obra. Na gestão Marta Suplicy, o projeto também não saiu do lugar. Rebatizado de Paulistão, recebeu 330 milhões de reais em investimentos. Os 174 pilares de concreto na Avenida do Estado eram um marco negativo na paisagem paulistana e davam a impressão de que nunca serviriam para nada. Sob o nome de Expresso Tiradentes, parte da obra finalmente foi inaugurada no ano passado [2007], sob a gestão Gilberto Kassab." (Veiga, 2008)
} 
mapa, agora, deve incorporar esse/ traço bloqueado, tempo mais que espaço, estar preso. [...] Agora ou nunca, cada mínima tormen-/ ta adensa a duração do impasse. (As mãos atadas do/ poema.)". No poema seguinte, a obstrução é causada pelo desabamento de um túnel. O eu lírico, apresentado como leitor em face da notícia, identifica-se com as vítimas, medita sobre a sorte delas e as imagens de trancamento se sucedem, do túnel às possíveis sequelas do acidente, até atingir por fim a leitor, forçado a levantar a cabeça "da página trancada".

Em “Assuntos", entretanto, o foco recai mais diretamente sobre a sociabilidade, reconstituída habilmente por meio do rápido encadeamento das falas, mostrando o problema da insegurança como um dos componentes do bloqueio circulatório, que é fruto de múltiplos fatores.

Discutindo os vínculos entre os bloqueios da cidade, a segurança pública e a canção popular brasileira, o poeta Pádua Fernandes (2011) menciona como uma das canções-emblema de São Paulo - "Trem das onze", de Adoniran Barbosa - também pode ser lida como canção da cidade bloqueada. Outros eram os tempos, outro o tamanho da cidade, outra a situação do transporte coletivo. Fernandes, todavia, a pretexto de uma gravação recente da música ${ }^{73}$, de arranjo sombrio, se pergunta se (e em que condições) o passageiro aflito que ainda se desloca por São Paulo conseguirá chegar até sua casa. E então conclui: "A casa precisa ser olhada: a insegurança (outro fator de bloqueio da cidade), mais do que o Édipo, preside esta interpretação" (Fernandes, 2011).

Do bonde afeito à experiência fugaz do companheirismo ao ônibus em que o silêncio descompacta os passageiros ou àquele no qual a conversa interrompida frisa o receio de que o desembarque assinale a derradeira viagem, vemos pouco a pouco se descortinar o rol efeitos subjetivos decorrentes de configurações particulares do encontro em veículos de transporte coletivo. Contudo, a violência enfocada em "Assuntos" pode também aliar-se ao erotismo e assumir outras feições, como se verifica em "Num ônibus indo para", poema de Paulo Ferraz:

\footnotetext{
${ }^{73}$ Refere-se à interpretação de Mônica Salmaso no CD Alma lírica brasileira, de 2011.
} 


\title{
NUM ÔNIBUS INDO PARA
}

\author{
Umas sobre as outras \\ as carnes assomam, \\ no aleatório que há de \\ corpos se tocarem: \\ a omoplata encontra, \\ após a cabotagem, \\ o porto de um tórax, \\ se ancora; agora, este \\ suporta a investida \\ da escrita das unhas \\ silente. Irrisório \\ saber qual porção de \\ abuso compõe a paz que o \\ suspiro comporta.
}

(Constatação do óbvio, 1999, p. 14)

Mais uma vez aqui o poema nos põe diante do drama, anteriormente referido, da superlotação no transporte público. O caráter adverso e desumano do deslocamento nessas condições é sinalizado inicialmente pela imagem das carnes que se empilham, aplicada aos passageiros. No entanto, o desconforto aí descrito parece sofrer, a partir do sexto verso, uma espécie de neutralização pelo recurso à metáfora náutica. ${ }^{74} \mathrm{O}$ vento brando e benévolo da navegação costeira (cabotagem) transforma o empurra-empurra em ancoragem e o corpo contra o qual se é comprimido em porto onde se pode relaxar.

A reação possível (investida das unhas) perde seu gume agressivo ao se converter em uma escrita silenciosa (quiçá uma declaração de amor, com direito a suspiro e tudo) que dispensa a investigação da porcentagem de abuso (irrisório saber) nessa duvidosa composição de paz. O poema não é explícito em relação ao sexo das pessoas envolvidas

\footnotetext{
${ }^{74} \mathrm{O}$ uso de metáforas náuticas para descrever a viagem de ônibus aparece também em Pierre Sansot, que afirma ser a viagem de ônibus, dentre as várias formas de deslocamento urbano, "a única que se aproxima de um passeio marinho." (Sansot, 2004, p. 300). Encontramos o mesmo tipo de metáfora, ligada à esfera semântica do desastre, em depoimentos colhidos pela antropóloga e poeta Janice Caiafa (2007) em pesquisa sobre os ônibus no Rio de Janeiro. Em um desses depoimentos, um passageiro compara o ônibus ao Titanic, o transatlântico que, em 1912, submergiu depois de chocar-se com um iceberg, no mais célebre acidente marítimo do século XX. Afirma o passageiro: "Veja bem, eu acho a coisa justa, mas ali no coletivo você está numa situação agressiva, é uma situação agressiva. Então é salve-se quem puder. Sabe como é? Se o barco naufragar, eu vou pular. Não vou deixar primeiro as crianças, depois as mulheres, depois os idosos, depois você, entendeu? Gentlemen ficam por último, né? É tipo Titanic. Eu acho que seja um Titanic, um ônibus é um Titanic. Ele pode bater, pode incendiar, pode ser assaltado, pode não sei mais o que e tal. [...] quando você junta muita gente, junta dentro de um ambiente pequeno, obviamente rola uma situação assim no ar, agressiva, né? Você não tá numa situação confortável, você tá sentado ao lado de alguém que você mal conhece, que você nunca viu na vida, pessoa que tá... pode tá com cheiro debaixo do braço, pode ser um cara que tá com as pernas abertas. Isso rola muito entre homens. Uns abrem muito a perna e você fica com a perna encolhida assim para não roçar na perna do cara, ou então você força um pouco a barra, abre a tua também. Então tem essa coisa meio agressiva, sim. Então eu acho que, quando o cidadão se encontra num estado mais agradável, mais relaxado ele fica mais cortês, ele entende a terceira idade, ele realmente ajuda, é uma coisa assim. Agora na hora de rush, uma hora de seis da tarde, hora de pico, rola realmente um clima tenso, entendeu? É uma tensão no ar". (Caiafa, 2007, p. 91-2).
} 
nesse "abuso pacífico", mas a referência às unhas, ao suspiro e ao "tórax-porto", sugere a natureza do encontro: uma mulher abordada por um homem.

É de perguntar se, a despeito do tom meio irônico e bonachão, o poema não deixa escapar uma ponta de machismo, atenuando o problema da violência sexual contra as mulheres, imputando-lhes desejo e transformando-as de vítimas em sedutoras responsáveis pelo abuso.

A questão retorna em dois outros poemas do autor, reunidos no livro Evidências pedestres (2007): "Motorista - linha 478-P" (p. 56) e "Violão (Bossa Nova) de Rua" (p. 20). No primeiro deles, reencontramos a evocação náutica aplicada à figura do motorista, cuja autoridade (exercida contra uma passageira que torce para um time rival) é exagerada: "No mar, capitão com Deus se/ parelha; no ônibus, ele”. (Ferraz, 2007, p. 56). No segundo, há uma retomada da perspectiva erótica no transporte coletivo que vale a pena comentar:

\section{VIOLÃO (BOSSA NOVA) DE RUA}

Vinha do trabalho, talvez secretária, ou fosse lá o que fosse que num escritório se obriga a ter certo padrão de aparência, vê-se pela roupa, que embora não seja uniforme, tem jeito de (um conjunto cáqui, o tecido já gasto, as linhas começando a se soltar). Nos pés, sapatos ordinários, bastante rodados, o couro sintético está desgastado, tendo adquirido a forma dos ossinhos, pelas solas notase que não reside perto da parada, caminha, caminha, provável que por uma rua sem asfalto, ou 
não seriam de lama as

manchas? Nós devíamos

levá-las nos braços.

Quanto tempo gasto

dobrando papéis e

sorrindo? Ainda há pouco

menina, e agora esses

cabelos que faltam

só serem grisalhos

e esse lápis (lápis?)

contornando os olhos.

O cansaço é tanto

que ela simplesmente

se esquece do corpo,

da postura certa, e

deixa-se, menina-

mente, pelo menos

aqui, cair são as coxas

a escora dos braços.

Um pingente, Nossa

Senhora de Alguma

Coisa, faz um pêndulo

(padroeira, advogada?), a

blusa por debaixo

do casaco solta-se e

se projeta, dando a ver

seus dois peitinhos,

únicos resquícios

de felicidade,

que nos solavancos

fazem uma algazarra,

como se quisessem es-

capulir. Que graça,

mais do seu ladinho e

poderia ouvir risos.

Vou fazer um poema.

(Evidências pedestres, 2007, p. 20-22)

Embora aqui o ônibus funcione como cenário, pano de fundo para a secretária suburbana que captura a atenção do eu lírico, a descrição que dela se oferece incorpora-o não apenas como marca de classe, como meio de conexão à cidade e ao trabalho, mas também como fonte de interesse erótico. Senão vejamos: da roupa gasta, com jeito de uniforme, passa-se aos calçados, qualificados por um adjetivo tomado de empréstimo aos 
veículos ("rodados") e cujo mau estado revela ainda como a vantagem do automóvel sobre o ônibus se verifica tanto na redução do tempo e da velocidade de deslocamento quanto no ganho em "microacessibilidade" - termo que define a possibilidade de acesso real aos destinos, medido pelo tempo necessário para a chegada ao destino final, depois de deixar o veículo, ou o tempo que a pessoa gasta para chegar ao veículo, depois deixar o local em que se encontrava ${ }^{75}$. Assim, sapatos gastos e enlameados indicam a exigência de longas caminhadas após a via-crúcis do ônibus lotado, por ruas sem asfalto, possivelmente na periferia, constituindo também mais uma evidência de segregação socioespacial, em que a distância entre moradia e trabalho é acentuada pela precariedade do transporte e da infraestrutura urbana.

O ônibus-cenário conecta então vários modos de circulação, informando sobre a origem social da personagem e sobre seus percursos entre moradia e trabalho. Mas a precariedade do transporte público modela também o corpo dos usuários e influencia a relação que se estabelece entre eles. O cansaço e a superlotação tornam as coxas da passageira escora dos braços e os solavancos dão a ver o espetáculo dos peitos em algazarra e riso, suposto ponto de partida do poema, cujo disparador é revelado ao final ("Vou fazer um poema").

Curiosa, no entanto, é a atitude do eu lírico, que, embora igualmente submetido às duras condições de transporte, afeta certa superioridade em relação ao objeto de seu desejo. O caminho rumo à excitação passa, sem abandonar tais posições, por um misto de reprovação (em relação à aparência standard e gasta das roupas, indicadoras de trabalho subalterno), pela condescendência "semicavalheira" ("devíamos levá-las nos braços”) e por uma compaixão excitada ante os peitinhos em que a felicidade se manifesta tão somente como resquício.

Mas talvez seja preciso desconfiar dessa superioridade, ou ao menos relativizá-la. Em um poema mais antigo, "No w here" (p. 22), de Constatação do óbvio (1999), encontramos a descrição de uma cena semelhante, um sujeito que embarca no ônibus, em que eu poético também ironiza sua condição de pedestre e usuário do transporte público: refere-se aos sapatos gastos, à calça amassada, comprada em suaves prestações, aos cabelos

\footnotetext{
${ }^{75}$ Referindo-se ao investimento em obras viárias que privilegiaram o transporte privado, otimizando os tempos de deslocamento de modo desigual (em 1977, os deslocamentos de automóvel consumiam em média metade do tempo consumido pelos deslocamentos de ônibus), Vasconcellos (1999, p. 201) alude também, ainda com dados de 1977, à desigualdade no campo da microacessibilidade, pois o tempo de caminhada para pegar ônibus naquele ano era cinco vezes maior que o necessário para pegar o carro - de trem, nove vezes maior.
} 
penteados com uma das mãos, que faz as vezes de pente, enquanto a outra conta as moedas para pagar a passagem.

Em "Violão (Bossa Nova) de Rua, porém, a presumida atitude de superioridade excitada talvez possa ser elucidada ainda pelo título, que remete à coletânea de poemas organizada por Moacyr Félix e lançada em 1962 como parte dos "Cadernos do Povo Brasileiro" editados pelo Centro Popular de Cultura. Tal publicação recolhia exemplos de uma poesia engajada, avessa à experimentação formal, identificada com as expressões genuinamente populares, ainda que ao preço de muita idealização do chamado "homem do povo". No campo da música, as canções engajadas também derivam de uma franja politizada da Bossa Nova, à qual em parte se contrapunham (Ridenti, 2010, p. 129), sobretudo na vertente mais lírico-evasiva dos banquinhos, barquinhos e tardinhas.

Pode-se então aventar a hipótese de que o poema de Ferraz estaria ironizando o interesse dos artistas oriundos das classes médias urbanas pelas "classes populares", servindo-se do erotismo e simulando uma pretensa superioridade, talvez em parte desmentida pela partilha sem privilégio do mesmo precário meio de transporte.

Vimos então como o deslocamento em veículos coletivos nas grandes cidades modela um tipo de sociabilidade e mobiliza todo um código de conduta, um padrão de cortesia cuja função é, de certa maneira, proteger os usuários contra o excesso de estimulação.

Com Mário de Andrade, observamos a permanência desse código de cortesia em funcionamento mesmo sob o risco (e a tentação) de dissolvência do eu na turba. Já nos poemas de Duda Machado, Tarso de Melo e Paulo Ferraz, no contexto contemporâneo de precarização do transporte público, testemunhamos formas "anômalas" de ativação daquele código, seja pela conversão desesperada do silêncio em espaço (Machado), seja pelo isolamento decorrente do vínculo estrutural entre bloqueio circulatório e insegurança pública (Melo) ou pela erotização como salvaguarda de alguma espécie de controle, domínio ou distinção em circunstâncias marcadas pela heteronomia (Ferraz). 
Não se trata de imaginar, todavia, com base nos comentários precedentes, que a precarização do transporte coletivo tenha produzido propriamente uma ruptura absoluta em relação às condições de circulação vigentes na pauliceia marioandradina ou, bem antes, na "berlineia" de Simmel. Afinal também elas comportavam seu tanto de reificação, submetendo os indivíduos às forças da divisão (e da especialização) do trabalho, aprisionando-os em uma cadeia de dependência infinita - o que justamente engendrava a atitude blasé, base da vida mental metropolitana, segundo Simmel. No entanto, a magnificação das tensões, do cansaço e dos bloqueios em cidades onde a desigualdade econômica se traduz em desigualdade na ocupação do território e em desigualdade "cinética" (desigualdade nas velocidades e na duração dos deslocamentos) parece definir, no interior dos titanics em que se transformaram nossos ônibus, padrões de sociabilidade bastante diversos, inviabilizando em alguns casos o gozo da companhia alheia, fonte de intensa ameaça. 


\title{
Capítulo 3. Poética do desabrigo
}

\author{
I. Origens da tragédia habitacional
}

Há um sono de pessoas e pequenos animais capturados, inofensivos, suspensos, protegidos pelo cimento, espreitados pelo vento, um sono solidário, tão puro!', que a casa perde seu caráter hostil e também ela boia na noite, grande flor muda que, ao primeiro grito, se despetala.

Carlos Drummond de Andrade ("Esboço de uma casa", Confissões de Minas)

Em um país cujo desenvolvimento urbano resultou no atendimento desigual do direito à habitação, chama a atenção a frequência com que os temas da moradia precária e do desabrigo aparecem, por exemplo, na música popular brasileira ao longo do século XX. De "O orvalho vem caindo", de Noel Rosa, a "Saudosa maloca", de Adoniran Barbosa, passando por "Ave-maria no morro", de Herivelto Martins, pululam na memória de nosso cancioneiro as imagens dos barracões de zinco, "sem telhado, sem pintura", das portas de barraco sem trinco, da cama reduzida à folha de jornal, das "tauba" caindo e doendo no coração da população pobre, empurrada para a periferia dos grandes centros urbanos.

$\mathrm{Na}$ poesia brasileira do mesmo período, no entanto, a impressão que se tem é a de que o problema da habitação e da segregação espacial da população de baixa renda não mereceu atenção equivalente. Por exemplo, em um poeta como Drummond, fortemente voltado para as questões urbanas, parece um tanto tardio o aparecimento de uma suíte de poemas inteiramente dedicada à favela. ${ }^{76}$ Claro que vamos encontrar, em Drummond,

\footnotetext{
${ }^{76}$ Trata-se de "Favelário nacional", publicado em Corpo (1984). Numa rápida folheada pela obra drummondiana encontram-se vários poemas que abordam, de modo mais ou menos direto, a construção civil, a memória das casas, o convívio e o isolamento em edifícios, o diálogo entre habitação e paisagem, entre outros temas e motivos. Lembro-me de "Construção" e "A rua diferente" (de Alguma poesia, 1930); "Privilégio do mar" e "Noturno à janela do apartamento" (de Sentimento do mundo, 1940), "Edifício Esplendor" (de José, 1942), "Edifício São Borja" (de A rosa do povo, 1945), "Opaco", "Morte das casas de Ouro Preto" (de Claro enigma, 1951), "Domicílio" (de Fazendeiro do ar, 1955), "A um hotel em demolição" (de A vida passada a limpo, 1959), "O mar, no living", "Aspectos de uma casa" (de As impurezas no branco, 1973) e de vários poemas da série Boitempo. Claro que se trata de uma lista grosseira, pois muitos desses poemas tratam também de outros temas, alheios à questão habitacional (a qual, por seu turno, pode aparecer em poemas sobre outros assuntos). De toda maneira, se considerarmos com exclusividade a questão da moradia precária, que engloba não apenas as favelas, mas também os loteamentos irregulares e clandestinos e a população em situação de rua, a lista se reduz de modo drástico. A favela aparece, contudo, em poemas como "Morro da Babilônia" (de Sentimento do mundo, 1940) e "Alagados na Bahia" (de Discurso de primavera e algumas sombras, 1977). Especificamente em relação a "Favelário nacional", o poema chama a atenção pela diversidade de perspectivas que reúne, com observações agudas sobre a paisagem, a arquitetura, os topônimos, os confrontos entre a cidade legal e a ilegal, os dilemas entre remoção e urbanização da favela, a fome, o lixo, a morte etc. Quanto à entrada relativamente tardia do tema na poesia drummondiana, vale lembrar que a noção de favela como um tipo de ocupação ilegal, com tamanho mínimo de cinquenta unidades, construída de modo precário e mal servida de equipamentos públicos já era empregada desde o Censo de 1950. E que a difusão midiática e a consequente internacionalização do termo começaram a ocorrer a partir dos anos 1960, por meio de obras como Orfeu da Conceição, filme de Marcel Camus, e da tradução para línguas estrangeiras de um livro como Quarto de despejo, de Carolina Maria de Jesus, conforme nos explica Valladares (2010). De todo modo, conforme indicaremos a seguir, os anos 1980, quando o poema foi publicado, representam uma espécie de marco na constituição da crise habitacional como a conhecemos hoje.
} 
Bandeira, Cabral e outros autores canônicos, muitos poemas sobre a pobreza em que o morar desempenha importante papel. São mais raros, porém, textos voltados para a segregação territorial como forma de dominação que orienta a produção social do ambiente urbano.

Trata-se de um fenômeno relacionado às raízes patrimonialistas do processo de urbanização no Brasil, cujos marcos são a Lei da Terra de 1850, que privatizou a terra assegurando às elites a propriedade, e a emergência do trabalho livre a partir de 1888, para o qual nunca se previu o custo de moradia na reprodução da força de trabalho urbana. ${ }^{77}$

Dadas desde o século XIX as condições para a produção da cidade informal/ilegal, o grande impulso para a urbanização segregacionista não ocorrerá senão a partir da segunda metade do século XX, mais especificamente com a política habitacional centralizadora implementada durante o regime militar por meio do Banco Nacional da Habitação (BNH), ligado ao Sistema Financeiro da Habitação (SFH). O direcionamento de recursos federais para o mercado habitacional em escala jamais vista mudou o perfil das cidades, que se verticalizaram com os edifícios de apartamentos, principal forma de provisão de moradia para a classe média. Investimentos em saneamento também foram consideráveis, e o crescimento do Produto Interno Bruto (PIB) se apoiou de modo significativo na construção civil. No entanto, o mercado, impulsionado pelo crédito imobiliário, priorizou o atendimento às classes média e alta, empurrando a população de baixa renda para conjuntos habitacionais na periferia, sem infraestrutura urbana, longe dos centros de emprego etc., forçando-a a longos deslocamentos da moradia ao trabalho, com impactos negativos sobre a mobilidade urbana (sobrecarga do sistema viário e de transporte coletivo) e aumento da desigualdade territorial. $^{78}$

Contudo, o que se seguiu à política habitacional adotada no período da ditadura (centralizadora, voltada para a classe média) foi ainda pior. Com a crise fiscal ocorrida durante os anos 1980 e o declínio do BNH, os investimentos em habitação e saneamento nunca recuperaram o patamar atingido nos tempos do milagre econômico. Vários autores

\footnotetext{
${ }^{77}$ Lembra Maricato (2002, p. 23) que "o crescimento urbano sempre se deu com exclusão social, desde a emergência do trabalhador livre na sociedade brasileira, que é quando as cidades começam a ganhar dimensão e tem início o problema da habitação". Como esclarece a autora, a política de industrialização com baixos salários expulsou do mercado imobiliário mesmo os trabalhadores regularmente empregados, obrigando-os a construir suas casas em áreas irregulares ou invadidas. Francisco de Oliveira também aponta como tal solução habitacional atende aos interesses da acumulação capitalista, barateando o custo monetário de reprodução da força de trabalho urbana (Crítica à razão dualista e O ornitorrinco. São Paulo: Boitempo, 2003, p. 103, apud Ferreira, 2011, p. 76).

${ }^{78}$ Exemplo eloquente dessa desigualdade territorial é oferecido por Bonduki (2011, p. 25-6): "No distrito da República, existem mais de seiscentos empregos para cada cem moradores, índice que na Cidade Tiradentes, no extremo da Zona Leste, cai para oito".
} 
situam esse momento como a matriz de um novo padrão para a tragédia urbana brasileira, um padrão diferente daquele encontrado nas canções e poemas sobre moradia precária e desabrigo a que nos referimos no início. As páginas seguintes vão se dedicar ao exame de alguns exemplos na poesia brasileira recente que, de alguma forma, apontam para essa nova dimensão do "habitar em crise", dando seguimento à investigação sobre as representações do espaço urbano na poesia brasileira contemporânea.

Porém, antes de entrarmos nos poemas, convém acrescentar elementos que permitam uma melhor compreensão dos percalços sofridos pela política habitacional até os dias de hoje.

Paradoxalmente, é durante as décadas de 1980 e 1990 - época pautada pela agenda neoliberal, em que houve refluxo dos recursos públicos para construção de moradias e ausência efetiva do Estado na definição de uma política urbana - que começaram a ser implantados os direitos habitacionais (a Constituição de 1988 incluiu pela primeira vez um capítulo sobre política urbana e reforçou a importância da função social da propriedade, presente desde a Constituição de 1934) e se lançaram as bases para a agenda da Reforma Urbana, que orientou por algum tempo o trabalho do Ministério das Cidades.

A criação do Ministério das Cidades, em 2003, antecedida pela promulgação do Estatuto da Cidade, em 2001, prenunciava uma guinada em relação à falta de investimentos públicos em habitação e saneamento ${ }^{79}$, bem como o compromisso com as propostas da Reforma Urbana - voltada para a afirmação dos direitos daqueles que, sem acesso à terra urbanizada e ao mercado imobiliário, constituíram assentamentos informais, para a implementação de um modelo de urbanização calcado na função social da propriedade e para a gestão democrática do território. ${ }^{80}$

$\mathrm{O}$ ativismo político dos movimentos de moradia popular, no âmbito do Ministério das Cidades, chegou até a esboçar, por meio de um projeto de lei, um Sistema Nacional de Habitação de Interesse Social (SHIS), de certo modo equivalente ao Sistema Único de Saúde (SUS) na área da saúde. E mais de 70\% dos Planos Diretores dos municípios haviam delimitado as Zonas Especiais de Interesse Social (ZEIS) em áreas vazias da cidade para

\footnotetext{
${ }^{79}$ Lembra Maricato (2011, p. 14): "No início de 2003, apenas seis dentre as 27 companhias estaduais de saneamento não estavam falidas ou extintas: SP, PR, DF, MG, ES e CE. O mesmo destino tiveram as Cohab, que foram orientadas para extinção durante o governo de FHC".

${ }^{80}$ Sobre os princípios que nortearam as ações do Ministério das Cidades e seu posterior desvirtuamento, ver depoimento de Rolnik (2011).
} 
baixar o preço da terra. Tais avanços, no entanto, rapidamente perderam importância, sobretudo após o lançamento do pacote habitacional "Minha Casa, Minha Vida", em 2009, que praticamente deu as costas para o trabalho anterior realizado pelo Ministério das Cidades e transferiu à iniciativa privada a responsabilidade de produzir moradias para a população com renda familiar mensal entre 0 e 10 salários mínimos. Dispensando em grande medida a gestão pública, esse programa investiu dinheiro diretamente no mercado a fim de contornar a lentidão dos Programas de Aceleração Econômica (PACs), as dificuldades na aplicação de recursos pelos poderes municipais e o desmantelamento das Companhias de Habitação (Cohabs) e das secretarias de Habitação.

O pacote, cuja meta inicial era a construção de 1 milhão de moradias, transferiu recursos (da União e do Fundo de Garantia por Tempo de Serviço (FGTS), subsídios da ordem de 34 bilhões de reais) sob a forma de crédito imobiliário para atender segmentos da população tradicionalmente excluídos do mercado formal. Apesar do perfil distributista, a verdade é que a maior parte dos recursos não foi para a população mais necessitada. Como revelam Arantes e Fix (2009), para a população que representava 82,7\% do déficit habitacional urbano, com renda abaixo de 3 salários mínimos, foram previstas somente $35 \%$ das unidades do pacote (o que equivale a apenas $8 \%$ do total do déficit para essa faixa de renda, ao passo que a faixa entre 3 e 10 salários mínimos seria atendida em $70 \%$ do seu déficit, embora represente só $12,5 \%$ do déficit habitacional total ${ }^{81}$ ). Assim, afirmam os autores, "o atendimento aos mais necessitados se restringirá, sobretudo, ao marketing e à mobilização". 82

A despeito da rapidez e da incompletude desse histórico, ele fornece algumas pistas do rumo tomado pela política habitacional brasileira nos últimos decênios bem como no momento atual, comprometido com uma tendência internacional de financeirização da moradia em que o acesso à habitação se dá via mercado, pela ampliação do acesso ao crédito. Na falta de controle social e de políticas de gestão do solo pelo Estado, estimula-se a especulação, o que acaba por elevar o preço da terra urbana, a qual, apesar de todas as

\footnotetext{
${ }^{81}$ Arantes e Fix (2009) citam o relatório sobre déficit habitacional elaborado pela Fundação João Pinheiro com dados de 2000. O relatório de 2008, com dados do Instituto Brasileiro de Geografia e Estatística (IBGE) e da Pesquisa Nacional por Amostra de Domicílios (Pnad) desse mesmo ano, refere-se à faixa entre 0 e 3 salários mínimos como correspondente a $89,6 \%$ do total do déficit habitacional. Estendendo a faixa até 5 salários mínimos, a porcentagem sobe para 96,6\% (Brasil, 2011, p. 35). O recálculo com base nos dados do Censo 2010 ainda não foi feito.

${ }^{82}$ Os autores revelam ainda de que modo o pacote mobiliza a ideologia da casa própria contra "a incompletude dos sistemas de proteção social", mercantiliza o direito à moradia, oferece produtos sem qualidade arquitetônica nem preocupação ambiental, entre outras incoerências.
} 
promessas em contrário, continua inacessível para a população pobre. Fomenta-se dessa maneira a cidade ilegal, com agravamento da crise no transporte, na infraestrutura, sem falar dos prejuízos socioambientais. ${ }^{83}$

Mas, se aceitamos que esse estado de coisas sugere de fato um novo patamar de tragédia urbana e de crise habitacional, cumpre indagar, no âmbito das discussões sobre o "retorno ao real" da poesia brasileira contemporânea, se essa crise "habita" de alguma forma os poemas de que é contemporânea. É o que veremos a seguir, com base no trabalho de três poetas que tematizaram de modo privilegiado tal problema: Pádua Fernandes, Régis Bonvicino e Tarso de Melo.

\section{Sopro, ilusão e pedra: a cidade-puta na poesia de Pádua Fernandes}

Em Cinco lugares da fúria (2008), Pádua Fernandes dedica uma seção inteira à questão do patrimonialismo fundiário e do papel desempenhado pelo vazio na edificação de uma cidade para as elites. Trata-se do terceiro lugar da fúria, "Mapa progressivo do oco", composto por sete poemas com longos títulos narrativos, como as legendas (ou didascálias) da poesia barroca, a saber: "De como o senhorio apresenta as suas vastas glebas e garbos a seus inquilinos"; "De como a lei e os oficiais apresentam seus largos e luminosos ofícios a seus vassalos"; "De como o senhorio ouve os vassalos e os atende no amplo céu"; "Da casa de suplicação e seus frutos logo dependurados"; "Da casa de suplicação e seus frutos já dependurados ao vento e ao público necessitado de espetáculos"; "Da casa de suplicação e seus frutos já descidos e cortados para ornar cada esquina com a lembrança rubra do reino"; "Do único senhor dos senhorios, glebas, ofícios, céus, casas e frutos".

\footnotetext{
${ }^{83}$ Tal panorama não autoriza muita esperança, mas precisa ser reavaliado a todo momento à luz de contradições que não cessam de surgir. Veja-se, por exemplo, decreto recente do prefeito de São Paulo, Gilberto Kassab, determinando a aplicação do Imposto Predial e Territorial Urbano (IPTU) progressivo para imóveis desocupados. O mesmo prefeito que delega à iniciativa privada o direito de desapropriar (em projetos como o Nova Luz, alvo de severas críticas) "ameaça" utilizar, com atraso de uma década, um instrumento previsto no Estatuto da Cidade. A primeira listagem de imóveis e terrenos sem uso foi publicada em setembro de 2011. A área ociosa já identificada somava mais de 3 milhões de metros quadrados (área que, ocupada, poderia atender ao déficit habitacional da capital, além de conter o espraiamento descontrolado da mancha urbana). Ver Zanchetta e Bulgarelli (2011). Ainda segundo a notícia, o Plano Municipal de Habitação prevê a construção de 740 mil moradias para zerar esse déficit, o que só acontecerá em 2048, caso se mantenha o ritmo atual de investimentos.
} 
De imediato, os títulos definem a relação entre a cidade e seus habitantes pelo viés da propriedade, da divisão entre senhores e inquilinos/vassalos - o que evoca um sistema de relações de tipo feudal, associado a um vocabulário jurídico-processual, com oficiais e ofícios, petições e sentenças, execuções na "casa de suplicações".

Vamos aqui nos dedicar sobretudo ao comentário do poema que fecha a suíte, no qual um cupim, "animal metafísico", fera do vazio, apresenta-se como grão-senhor de todo o reino, dono de um poder que subjuga senhores e vassalos, terra e céus, casas e frutos. Mas, para chegar a compreender o poderio dessa minúscula fera, convém examinar o percurso que nos leva até ela.

A suíte se abre com um longo poema de onze estrofes de sete versos arrematados por um dístico, tudo em redondilha maior, com rimas (na maioria toantes) distribuídas de modo mais ou menos irregular, sem obedecer a um esquema preestabelecido. Fala nessa abertura o senhorio, detentor de glebas e garbos. Ele se apresenta como minoria superior, de europeia ascendência, a quem os outros "de alma ou de corpo mouros" devem se curvar "de alma ou de corpo".

O poema vai se construindo por meio das relações estabelecidas entre a cidade e seus ocupantes e das diferenças entre habitar a cidade e ser por ela habitado ${ }^{84}$ : os senhorios são habitados por Europa ("Europa mora em seus filhos”) e se dirigem aos mouros que constroem, com "sopro, ilusão e pedra", uma cidade "dos outros". Essa cidade é vocacionada à queda, tanto dos prédios ("não há prédios/sem as incrições da queda") como do exército de trabalhadores, que vieram "prontos para o próprio abate" numa terra onde jamais serão admitidos (“buscam lar onde o labor/ desterra”).

Metonimicamente, porém, a cidade se antropomorfiza e acaba por se identificar com aqueles a quem ela expulsa ("que a cidade não encontre morada" a não ser com "invasores", a maioria trabalhadora cuja pobreza, "mesmo limpa, é "crime contra a pujança" da "maior Cidade Branca"); ela se converte de local/instrumento de expulsão em objeto expulso.

\footnotetext{
${ }^{84} \mathrm{O}$ valor simbólico dessa cidade introjetada e as marcas subjetivas da perda do "direito à cidade" já haviam sido explorados pela MPB em uma canção como "Assentamento" (1997), de Chico Buarque, originalmente composta para o CD encartado no livro de fotografias Terra, de Sebastião Salgado. A exortação ("Vamos embora") para retomada da terra, após muita errância "periferia afora", é antecedida pelo verso "A cidade não mora mais em mim".
} 
Ocorre que a sequência metonímica vai além: a cidade não apenas perde a morada e vira invasora, mas também se desdobra em imagens corporais femininas ${ }^{85}$ que associam a vocação pública do espaço urbano à gravidez e à doença. Os edifícios vestem a cidade, porém sua pele resiste, nua "como fruto/ que fosse inteiro semente", prenhe de encontros e infecções ("temo/ que esses espaços defesos/ se convertam em encontro,/ e muros, roupas e becos/ se abram em ruas e troncos/ onde todos os viajores/ se infectassem com o outro"), mobilizando no senhorio o desejo de esterilização/interdição desse híbrido "entre o espaço e os invasores". É curioso como, do ponto de vista dos proprietários, a dimensão civil da hospitalidade, sentida como invasão, se sexualiza a ponto de demandar medidas de cunho contraceptivo ou abortivo.

Essa figuração de uma cidade-corpo aparece em muitos momentos de Cinco lugares da fúria $^{87}$, mas ganha força nas estrofes finais, em que a voz do senhorio vai sendo interrompida por parênteses e diálogos. É como se, isomorficamente, a ameaça se presentificasse nesses apartes em que o discurso senhorial especula sobre a gestação da cidade e responde aos inquilinos que reclamam da falta de luz (“- Cadê os interruptores?”), da qualidade da pintura ("“- Não gostei desta pintura.”) e, por fim, da porta com cupim (“Esta porta tem cupim.”). Perturbadora é a resposta à ameaça da cidade-fêmea, invadida e prenha, cuja gestação pode roubar chão, teto e tudo o que circunda a propriedade: resistirão a porta (sólida e europeia) e o trinco ("imune a invasores”) onde está a casa inteira.

De maneira hiperbólica, o poema chega a figurar a lógica patrimonialista a que nos referimos anteriormente, uma lógica que opõe casa e cidade ${ }^{88}$, fazendo com que a função social da propriedade se reduza ao papel defensivo/expulsivo que a ela se atribui (o trinco que, metonimicamente, contém toda a casa).

\footnotetext{
${ }^{85}$ Por certo não é nada nova essa vertente "feminizadora" nas representações poéticas do urbano, remontando, para ficarmos por perto, à Pauliceia desvairada de Mário de Andrade ("Pauliceia, minha noiva... Há matrimônios assim...", "Mulher feita de asfalto e de lamas de várzea" etc.). Assim, mais importante que identificar tal vertente é saber especificá-la, sobretudo em suas modalidades mais perversas/desviantes, à luz dos últimos avatares da urbe.

${ }^{86}$ Observe-se nesses poemas a associação entre os desdobramentos metonímicos, que tomam o "expulsor" pelo expulsado, com a presença de oxímoros como o da nudez vestida e dos "amargores do açúcar" no fruto-semente da cidade.

${ }^{87}$ No primeiro capítulo já havíamos nos referido aos "olhos" da cidade abertos pelos buracos de bala (p. 75), mas as metáforas corporais da cidade constituem uma obsessão que atravessa toda a poesia de Fernandes. Em um trecho de "Pisando folhas secas", poema de Cálcio (2012), lê-se: "mas a cidade também é um corpo/ basta cegá-la para ver/ que ela tinha olhos/ basta amputá-la para saber/ que ela tinha membros/ pisoteá-la/ e descobrir a cotação dos ossos/ torturá-la para ouvi-la/ pena que não diga palavra alguma/ articulada para os ouvidos/ que esperam o ponto de os ossos cederem/ e cantarem com sua voz seca/ que tudo é um corpo e morre" (Fernandes, 2012, p. 13).

88 "Como você tem um descompasso total entre a política de financiamento de moradia e a política de gestão de solo, que não existe, que foi desconstituída, e sem nenhum controle social, sem nenhuma forma pública de trabalho, está se fazendo casa sem cidade." (Rolnik, 2011, p. 15)
} 
O segundo poema da suíte, dedicado ao discurso legal e acadêmico, instaura, do ponto de vista formal, uma ruptura em relação ao que veio antes: trata-se de um discurso em prosa, a defesa de uma tese doutoral, na área de "O direito e a cidade" (a conjunção aditiva em vez da preposição "da" indica a distância entre os termos, um direito que se põe contra a cidade ) sobre o tema "A inseminação artificial e a responsabilidade civil". Mas a descontinuidade formal na passagem da poesia à prosa contrapõe-se à continuidade temática, pois o corpo urbano que guardava o sol entre as pernas, a cidade grávida, de gente ou de vermes, reaparece aqui na discussão sobre inseminação, nascimento e cidadania. O nexo aparentemente estapafúrdio entre inseminação artificial e responsabilidade civil revela uma lógica afim à do discurso senhorial do primeiro poema: a cidadania depende do nascimento, mas de um nascimento que deve ser regulado pelo Código Civil ("sem o Direito Civil não há cidade"). A gênese dos direitos é extremamente perigosa, donde a necessidade de permanente controle: a inseminação é artificial, quem recebe o sêmen (a mãe?) é o Código Civil, que deve exercer o pátrio poder sobre a filha cidadania, a qual exibe "insofismáveis sinais de prodigalidade" e, portanto, deve ser mantida sob tutela, "quiçá eternamente".

Assim como, no primeiro poema, o corpo urbano prenhe inspirava certo zelo abortivo, dada a identidade entre gestação e doença, aqui a cidadania jamais atinge a maturidade, os direitos não são reconhecidos e a lei não assegura a justiça, antes a impede, pois "a democracia precisa ser reformada para que se pareça com ruínas, e assim, atraia mais turistas (e capital estrangeiro), que a visitarão em massa como fazem hodiernamente com o Coliseu".

Revela-se assim a aliança entre os discursos senhorial e douto, acrecentando-se uma nova imagem à série de figurações da cidade a serviço das classes dominantes: a da ruína-espetáculo, que reduz a cidadania ao consumo e subordina o desenvolvimento urbano ao turismo predatório e ao capital estrangeiro.

Decerto a ruína já estava presente na referência ao cupim e ao trinco ao redor do qual tudo sumiu, mas as imagens então vão se somando, articulando-se em várias direções. A cidade-trinco se coaduna com a cidade-museu, temendo ambas a prodigalidade dos espaços abertos e verdadeiramente públicos. 
O poema seguinte, "De como o senhorio ouve os vassalos e os atende no amplo céu", introduz o antagonismo de classe: após o discurso dos proprietários e de seus representantes legais, o discurso dos desapossados, no caso um desempregado, louco e mendigo, que pede esmola defronte a um edifício com apartamentos de aluguel.

O poema divide-se em duas partes. Na primeira, vemos um diálogo entre duas vozes (uma das quais grafada em itálico), que depois sabemos ser apenas uma ("o louco pensa que é dois”), as quais especulam sobre o dono do prédio, de quem esperam uma esmola, ao mesmo tempo que contam algo da própria história (a de um evangélico que abandonou a igreja, perdeu o emprego e virou morador de rua). Na segunda parte, fala o proprietário que pede a remoção-extermínio do mendigo ("Quero o corpo longe") a fim de "repor o espaço".

O mendigo de voz dúplice expressa-se em prosa, enquanto a fala do proprietário é vazada em redondilha maior, como no primeiro poema. No entanto, a voz do mendigo, grafada em itálico, no esforço de compreender a natureza enigmática do proprietário, dono do prédio inteiro, vai se transformando em prosa poética, sendo tomada por metáforas. Essa voz estranha o fato de que um prédio inteiro, uma cidade inteira, pertença a um único dono. Ante os questionamentos aparentemente sensatos de seu alterego ("o dono não pode ter mais de uma casa? a família dele tem quase todo o bairro"), a voz então reage antecipando a violência subjacente a tal posse "concentracionária". Assim é que ela verifica não apenas a identidade entre dono e casa (porta, teto, chão, fechadura, tudo é dono), mas também a identidade entre o dono e "o caco que entra na pele e reflete o sol nas veias", "o céu, o raio que fere para substituir a carne pela tempestade". Tais equiparações parecem antecipar o destino violento reservado a "invasores" como ele. O final desse diálogo interno entre as duas vozes do mendigo soa também revelador. O dono atravessa a rua e a voz "sensata" constata que ele nada deu, não deu a esmola, ao que replica a voz "poética": "nada, ou o dono, a dádiva substitui o espaço".

Eis uma frase difícil de interpretar, dado o alto grau de condensação. Para além do jogo aliterativo entre "nada" e "dono", o que aí se esconde? Trata-se de uma referência ao montante de vazio que sustenta a especulação imobiliária, ao efeito desertificador decorrente da privatização do espaço publico, à própria conversão do dinheiro em vazio ("a dádiva substitui o espaço")? Se aqui, mais do que o tempo, o espaço é dinheiro, nada mais natural que se pague por sua "reposição" ou esvaziamento, como pede ao final o 
proprietário aos guardas. Tal positivação do vazio é antecipada no discurso do proprietário por comparações que se aplicam ao próprio mendigo, que "vivia no edifício/ como o exílio nos viajores/ e na arquitetura o míssil".

Os dois poemas seguintes, em forma de soneto - o primeiro com versos eneassílabos e rimas toantes interpoladas, o segundo com versos hexassílabos (à exceção do último verso dos tercetos, trissílabos) -, encenam o confronto entre cidade e polícia. A "casa de suplicação" é a rua e o suplício-espetáculo não é o enforcamento, mas a queimada, que encontra "cais" no "riso" (inusitada associação entre as esferas aquática e ígnea), liberando espaço. O tom do guarda é elevado, dirige-se à cidade na segunda pessoa do plural, o que contrasta com a baixeza de seus serviços: ele prostitui a urbe (o que é coerente com a figuração feminina e corpórea vista anteriormente), oferecendo proteção em troca de pagamento ("protejo-vos; agora pagai"), isto é, em troca da violência (os danos) que preserva os bens e os negócios. O plano urbano exige a ruína e o sacrifício dos que nada têm.

No soneto seguinte, fala a cidade. Ele começa com a pergunta "quem me acende o tributo?”, em que novamente se verifica um deslizamento metonímico (a causa pelo efeito). A cidade veste, pois, o fogo e acomoda no cais de fumaça a pele, a carne e o crânio de mendigos e outros invasores. O fogo, que inaugura "novo culto", tem seus efeitos descritos de modo paradoxal: ele derruba os frutos da cidade feraz, mas também exibe chamas que crescem "como trigo". Por fim, nomeado inicialmente como "veste", o fogo se confunde com a própria cidade e com seus frutos sacrificados: "sou fogo, sou humano". Purgado assim do humano, o urbano reduz-se ao dano ("de mim só resta o dano") e pede arrego: "me apagai", em um jogo fônico admirável com o "pagai" do poema antecedente, e que reforça o laço metonímico apontado no verso inicial.

O poema que se segue aos sonetos, o penúltimo da seção, parece remontar à estrutura estrófica dos sonetos anteriores, adotando, contudo, um verso mais curto (predominantemente trissílabo, como nos versos finais dos tercetos do poema anterior) e exibindo um terceto a mais, isolado na página à direita.

À diferença dos sonetos, em que um dos interlocutores estava sempre silente, esse poema é estruturado na forma de diálogo explícito, com travessões indicando a alternância do turno conversacional. Tal diálogo parece ocorrer entre a polícia (identificada pelo refrão 
mercenário "mas pagai") e os donos do bairro, agora limpo de mendigos. No entanto, o exílio dos estranhos, assegurado pelo pagamento de taxas, é novamente representado como um ataque ao urbano. O higienismo desumanizante é desurbanizante, como revelam as falas finais: - "E o humano?/ - Mas urbano/ não há mais."

Nesse momento a "narrativa" abandona as personagens humanas (polícia, mendigos, proprietários) e se encaminha para o epílogo monopolizado pela voz do cupim, referido rapidamente no primeiro poema, e apresentado agora como o único senhor "dos senhorios, glebas, ofícios, céus, casas e frutos". Eis o que ele diz:

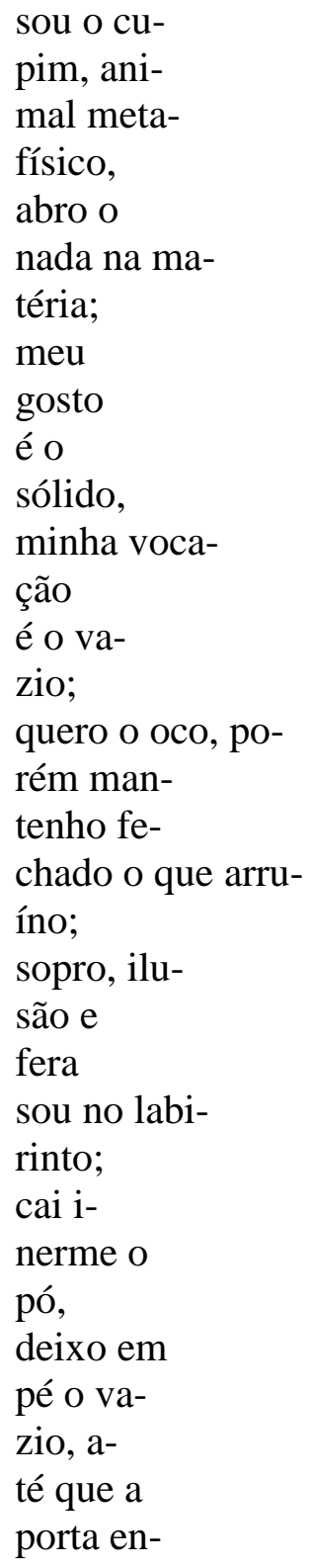




fim
plena do
oco (a verda-
deira
casa)
abra-se definitiva-
mente para o
nada; e a
porta con-
verta-se em um
híbrido entre a
rua e a
casa; e
nada fal-
te para que
toda a ma-
téria se re-
vele
tão
útero (o
útero
nu,
sem mu-
lher al-
guma)
quanto o es-
paço;
pois
sei
ver e fa-
zer o a-
bismo in-
teiro em
cada
muro,
sei do
oco que pal-
pita para liber-
tar-se de
todo
crânio,
sei que a
carne
é o
verme do
corpo e
deve




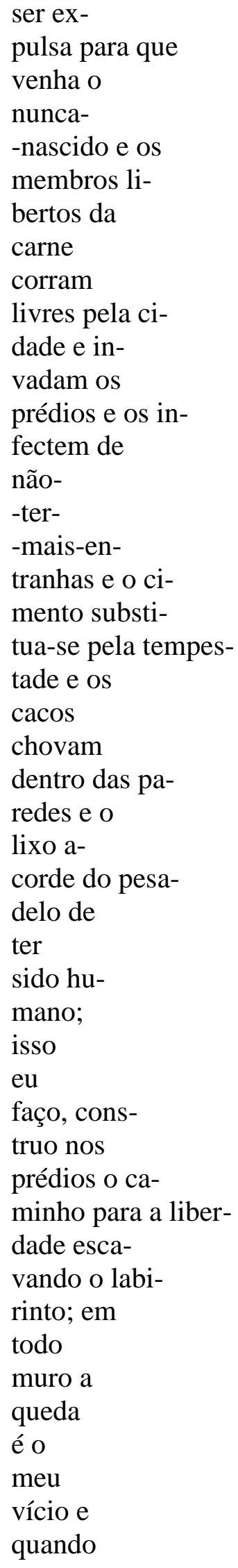




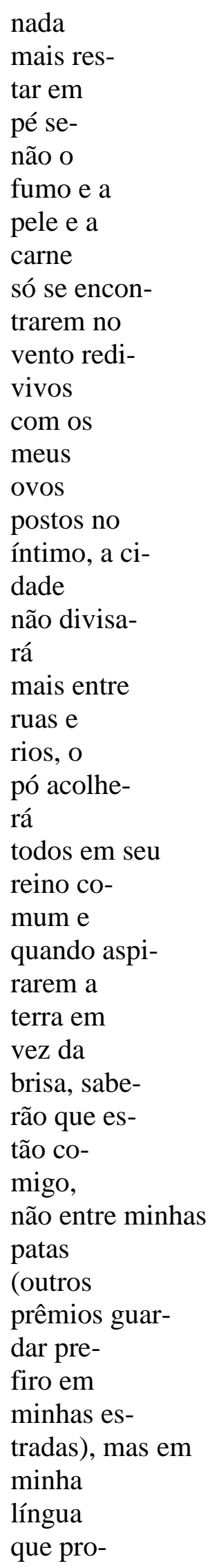




va e cons-
trói o va-
zio que
todo o
tempo
lá
já es-
tava
a
por-
tas
fe-
cha-
das
.

Há muitas coisas a observar nesse fecho-clímax. Para começar, o corte do verso na sílaba tônica, que cria uma espécie de tripa vertical semelhante aos túneis criados pelo cupim - introduz uma nota de novidade no velho recurso da technopaegnia, na medida em que a espacialização associa as necessidades icônicas a um critério rítmico. Em uma suíte povoada por formas fixas (como o soneto) e metros tradicionais (como a redondilha), a espacialização estabelece um forte contraste, que, no entanto, nada tem de arbitrário. O estreitamento do verso em torno do qual cresce o vazio figura a progressão do oco desurbanizador, um oco amigo do trinco, um oco que fecha as pernas da cidade e lhe extirpa o útero ("útero/ nu/ sem / mu-/ lher al/ guma”).

Os oximoros aqui retornam multiplicados: gosto do sólido $\times$ vocação do vazio; "abro o nada" × "mantenho fechado o que arruíno"; plenitude do oco etc. Mas a sequência prossegue num crescendo, o oco é a verdadeira casa que vai aumentando à medida que se liberta de tudo o que o restringe: o útero se liberta da mulher, o corpo se liberta da carne (chamada "verme do corpo"), parindo "o não nascido", libertando por conseguinte os membros e, passos adiante, acordando até mesmo o lixo "do pesadelo de ter sido humano" ${ }^{89}$. A inversão é completa e assustadora nesse processo em que a destruição e a extinção do humano aparecem como condição de criação e liberdade. A queda vira assim

\footnotetext{
${ }^{89}$ A reversibilidade entre homem e lixo reaparece no já mencionado poema "Pisando folhas secas", que começa com o esforço de formar uma figura humana com sucata: "uma caixa como perna, papelão, três embalagens de biscoito/ como dois braços, à maneira de cabelos as tampinhas de garrafa,/ folhas secas ou ossos - // a cabeça como caco de vidro, papelão, pernas como embalagens/ de absorvente, no papel de cal para muros os restos de unha,/ cotovelos ou ventania - // - não se formou a figura.// intercambiar os elementos;// - a figura nunca mais se formará" (Fernandes, 2012, p. 11).
} 
construção, repõe o espaço e alforria o vazio "que todo o tempo já estava lá a portas fechadas".

Com relação a esse cupim plenipotenciário, Fábio de Souza Andrade (2009), em recepção de primeira hora, afirmou que ele remetia "menos à leveza da pulga parabólica de Murilo Mendes que à estranheza inconcessiva do áporo drummondiano". A menção ao áporo drummondiano soa muito apropriada e permite especular sobre a natureza do "país bloqueado" com que se defrontam ambos os insetos. Em "Áporo", o bloqueio, que alude à ditadura do Estado Novo, tem valor claramente negativo, sendo positivo o trabalho do inseto, espelho degradado do trabalho poético em meio à realidade opressora. Já a escavação do cupim tem sentido contrário; em verdade, ela produz um bloqueio às avessas: ela desmancha a cidade, liberta o vazio e fecha a porta ao humano. Há labirinto nos dois poemas, mas enquanto o áporo é dele refém, o cupim é sua fera. Contra a cidade antropomorfizada, a ação do cupim é "entropomórfica”, produz entropia; caos em vez de orquídea.

A diferença também se verifica no ritmo com que ambos avançam: o do áporo, lento e regular, definido pelo verso em redondilha maior e pela contenção da forma soneto; o do cupim, veloz, irregular e desenfreado, definido pelo corte nas tônicas e pelo espraiamento vertical dos versos.

Por fim, quanto ao bordão do cupim-fera (“sopro, ilusão e fera sou no labirinto"), ele constitui uma variação ao que a voz proprietária afirmava no primeiro poema acerca dos mouros que ergueram a cidade "com sopro, ilusão e pedra", conectando o fim da suíte a seu início.

Sérgio Alcides, na orelha do livro, ao mencionar o poema do cupim, evoca o nome de Augusto dos Anjos como um possível antecedente para o tipo de poesia praticada por Pádua Fernandes. Certamente o grotesco das imagens (vermes, aborto, descarnamento) lembra o autor de "Os doentes", assim como, voltando ao artigo de Souza Andrade, o arremedo da voz "comendadora" das elites guardava relação com a poesia dramática do Cabral de Auto do frade.

Difícil é especificar aqui o campo de diálogo com a tradição de um conjunto de poemas que guarda algo dos jogos cultistas e conceptistas da poesia barroca - didascálias, acúmulo de oximoros, hipérboles, metáforas e metonímias, bem como de silogismos e 
sofismas (sobretudo no segundo poema) -, aproveita elementos da poesia dramática, da ironia modernista, da espacialização concretista etc. Sem embargo, não se trata de um uso anacrônico (combinatório ${ }^{90}$, maneirista) de elementos da tradição, sem vínculo com a experiência histórica presente. Ao contrário, o uso de formas pretéritas parece assinalar, em alguns momentos, o enraizamento da crise urbana em elementos de nosso passado colonial (por exemplo no que se refere ao patrimonialismo ou ao conluio entre as elites fundiária e intelectual), em outros, a apropriação distópica de procedimentos da vanguarda.

De todo modo, no que se refere à estratégia aqui adotada para representação do urbano, destacam-se a feminização da cidade e a "morbidização" do espaço público, que exageram e subvertem certos procedimentos da retórica higienista e do discurso ideológico sobre o funcionamento do "corpo social".

\section{$* * *$}

A seguir, examinaremos alguns poemas que tratam da população em situação de rua, a qual, somada ao déficit habitacional, talvez seja a faceta mais emblemática da segregação urbana.

Embora o contingente de moradores de rua represente menos de $1 \%$ da população das cidades brasileiras, conforme estudo recente realizado em 71 municípios (23 das quais

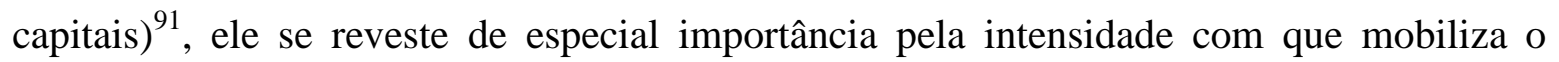
imaginário da pobreza, definindo uma espécie de exemplo-limite de abandono e infortúnio e suscitando muita justificação ideológica. Dos que pernoitam na rua (ou em albergues) costuma se dizer que não trabalham, que não têm profissão, que vivem às custas da rede de serviços de assistência etc. As pesquisas, no entanto, revelam: a maioria dessa população é formada por trabalhadores, que exercem atividade remunerada, sem carteira assinada (antes de ir para a rua, muitos estavam inseridos no mercado formal de trabalho), que sabem ler e escrever, que declaram ter alguma profissão, e poucos são os que se valem dos programas

\footnotetext{
${ }^{90}$ Segundo Simon (2011), a combinação arbitrária de formas e procedimentos acumulados pela tradição define um uso frívolo desta, frequente na poesia brasileira contemporânea. Afirma a autora: “A definição de tradição como 'contemporaneidade de formas' é curiosa: pressupõe que todas elas convivam sem atrito, e compartilhem o mesmo e generoso espaço, sem risco de serem acusadas de regressão, atraso, anacronismo e conformismo".

${ }_{91}^{9}$ Segundo a Pesquisa Nacional sobre a População em Situação de Rua (Brasil, 2008) tal estudo, esse contingente equivalia a $0,061 \%$ da população das 71 cidades pesquisadas.
} 
governamentais de assistência. ${ }^{92}$ Considerando a estigmatização sofrida por essa gente ao relento, é de se perguntar se a poesia brasileira recente, quando abre a boca para falar de quem vive no olho da rua, desempenha algum papel contraideológico, se opera algum deslocamento em relação aos discursos dominantes, se sucumbe a certo tipo de idealização (à maneira da poesia marginal dos anos 1970, que identificava a marginalidade poética à social, subestimando o peso concreto da segunda), se se limita a descrever a situação de rua, às vezes com minúcia naturalista, sem de fato refletir sobre ela, sem a contradizer.

É o que discutiremos a seguir, com base em exemplos colhidos em Régis Bonvicino e Tarso de Melo. Tais exemplos talvez reflitam, com certo atraso, o saldo das décadas de 1980 e 1990, período de estagnação econômica, de queda nos índices de emprego sob a batuta do neoliberalismo, bem como de recuo dos investimentos estatatais destinados à construção de moradias, conforme mencionamos anteriormente. Período em que começam a ser feitos de modo sistemático os primeiros estudos demográficos sobre a população em situação de rua, é também a partir do final dos anos 1990 que vemos se disseminar, no discurso jornalístico, termos relativamente novos, apropriados pela poesia, como a designação “antimendigo", aplicada a certos dispositivos arquitetônicos ${ }^{93}$.

\section{Porta da rua, serventia da casa: o desabrigo em Régis Bonvicino}

A propósito então dos moradores em situação de rua e da arquitetura antimendigo, examinemos dois poemas de Régis Bonvicino, extraídos de Céu-eclipse (1999). No primeiro capítulo já havíamos analisado um poema desse mesmo livro, focalizando a situação de medo e insegurança deflagrada pelo encontro com um mendigo. Agora,

\footnotetext{
${ }^{92}$ Alguns dados da pesquisa nacional: 70,9\% dos entrevistados exercem atividade remunerada, apenas $15,7 \%$ vivem de esmola, $74 \%$ sabem ler e escrever, 58,6 \% afirmaram ter alguma profissão e 88,5\% afirmaram não receber nenhum benefício dos órgãos governamentais. No último censo paulistano da população em situação de rua, os dados referentes ao perfil socioeconômico dos moradores de rua da área central são semelhantes: 90,5\% dos entrevistados declararam que sabem ler e escrever, $94 \%$ tinham uma ocupação antes de ir para a rua (67,6\% dos quais com registro em carteira), $66,9 \%$ exercem atividade remunerada e apenas $14 \%$ vivem de esmola. Em ambos os estudos a maioria dos entrevistados é de não brancos (67\% na pesquisa nacional e 64,5\% no censo paulistano) e já sofreu violência na rua $(66,7 \%$ no censo paulistano).

Segundo a pesquisa nacional, que excluiu as capitais de São Paulo, Belo Horizonte e Recife, para as quais já haviam sido feitos estudos específicos, a população em situação de rua, em 2008, nas cidades pesquisadas, contabilizava 31.922 adultos. Em São Paulo, o censo de 2009 computou 13.699 adultos (contra 8.706, no censo de 2000, o que configura um crescimento de quase $57 \%$ em menos de dez anos). Para os dados paulistanos, ver Fipe e São Paulo (2010) e Schor e Vieira (2010).

${ }_{93}$ Em pesquisa no acervo da Folha de S.Paulo, o termo "antimendigo" tem a primeira ocorrência em matéria de 1994. Ver Rocha Filho (1994).
} 
contudo, vamos nos dedicar mais exclusivamente à relação entre o morar e a situação de rua, como a descrita no poema a seguir.

\section{CASAS SEM DONO}

Farol - caixa de madeira, parede de viga, um sofá sacos, onde a cabeça, talvez abrigo. Meia-parede, o domínio do jardim, feldspato: cabeça reclinada na pedra - olhar, profundo, à noite, para a rua, cega. Largar-se, num muro baixo, tragando o cigarro, à vista, para quem passa - variação da casa, sob o toldo em frente, onde dorme, sempre. Dorso nu, braços cruzados à cabeça: colcha vermelha entre o corpo e o degrau - vaso oferecendo sombra, trama de branco e azul, na calçada sob a lona. Outra caixa, vazada, como cadeira. A rua, estreita, como porta, atravessando. Luz da tarde: a escada-passagem como quarto, sob árvores-frechais acima, de plástico leve, cadeira branca - arbusto, prédio, varanda. ${ }^{94}$

(Céu-eclipse, p. 71)

O poema se oferece como uma longa enumeração, de natureza descritiva e aparentemente objetiva, dos elementos e arranjos que, no meio da rua, exercem a função de casa. Destaca-se a relativa ausência de verbos (passa, dorme) e o uso de formas nominais, sobretudo de gerúndios, para configurar a parca ação (cabeça reclinada, braços cruzados, largar-se, tragando, oferecendo, atravessando), que é "exercida" tanto pelo morador (olhar, fumar, dormir) como pelos elementos de seu entorno (vaso e rua). Também chama a atenção o uso reiterado de comparativos (caixa como cadeira, rua como porta, escada-passagem como quarto) na tentativa de compor o espaço fechado da casa/abrigo com imagens que, ao contrário, só figuram o aberto, o precário e o transitório. Parte da força do poema advém, aliás, dessa "variação da casa", marcada pelo contraste entre intimidade e trânsito; casa em que há travesseiro (de pedra), colcha, sofá, cadeira, porta, mas também farol, pessoas passando, degrau, escada.

\footnotetext{
${ }^{94} \mathrm{O}$ poema foi republicado, com ligeiras alterações no corte das linhas/versos, na reunião Até agora (São Paulo: Imprensa Oficial, 2010, p. 206). Reproduzo o texto dessa edição mais recente, da qual também foram suprimidas as notas que acompanhavam o poema. Terá o poeta concordado com a crítica feita por Abel Barros Baptista? Ver, cap. 1, p. 58, nota 32.
} 
O uso do advérbio "sempre" ("variação da casa, sob o toldo em frente, onde dorme, sempre") é outro elemento que, sem sobressair de início, suscita inquietação. Referir-se-ia tal advérbio à invariabilidade do local em que se dorme, sempre o mesmo? A resposta afirmativa a essa questão, embora possível, soa um tanto improvável se levarmos em conta a mobilidade da população em situação de rua, o caráter "expulsivo" do espaço urbano das grandes metrópoles. Outra possibilidade seria pensar que o "sempre" aludiria não tanto ao "onde", mas ao "dorme", indicando um prolongamento psicológico da sonolência, um estado de contínuo torpor que também encontra fundamento fora do poema, na realidade da "situação de rua"95. Ainda que o confronto com o referente objetivo da representação seja arriscado - tendo em vista o peso da mediação estética, a autonomia do poema e os engodos do realismo ingênuo -, vale dizer que a ideia de um torpor permanente condiz com outros elementos do texto, especialmente com o desalento das ações da personagem, de caráter não produtivo, sem interação social.

Outros elementos que merecem comentário são as assonâncias (viga/abrigo; pedra/cega; toldo/dorso; sempre/frente; lona/sombra; vaso/vazada), a antítese em "olhar para a rua, cega" (onde se está sempre “à vista”), bem como o jogo, já mencionado, que faz da rua, porta; da passagem, quarto.

A fluidez da rua como locus habitandi é ainda reforçada pelas marcas de decurso do tempo, que liga a noite de um dia à luz vespertina do dia seguinte.

Por fim, após as "árvores-frechais", substantivo composto que funde a paisagem natural a detalhes arquitetônicos (frechais: vigas horizontais em que são assentados os frontais de cada pavimento), vemos o que se situa acima da rua, possivelmente o entorno das casas “com dono", de cuja varanda é possível contemplar o espetáculo do desabrigo. A descrição perfaz então esse caminho do farol à varanda, em que a enumeração de materiais (feldspato, madeira, plástico), cores (branco, vermelho, azul), posições e aspectos (sentado, deitado; cabeça na pedra, braços à cabeça; corpo largado, dorso nu) dispensam comentários

\footnotetext{
${ }^{95} \mathrm{~A}$ maioria da população que assim vive faz uso contínuo de substâncias psicoativas, como álcool e outros tipos de drogas. No censo paulistano de 2009 , essa maioria corresponde a $74 \%$ dos moradores entrevistados ( $80 \%$ no caso de jovens entre 18 e 30 anos). No censo federal, o alcoolismo é o principal motivo de ida para a rua (35,5\% o apontam), seguido de perto pelo desemprego (29,8\%) e pelas desavenças familiares $(29,1 \%)$. No entanto, cumpre lembrar do risco de generalizações indevidas aplicadas ao "povo da rua". Para tipologias contextuais dessa população, apoiadas em uma diversidade de critérios (estilo de vida, raio de ação/mobilidade, dimensões cognitiva, tempo nas ruas etc.), consulte-se o notável estudo etnográfico de Snow e Anderson (1998).
} 
subjetivos para sugerir a derrelição inerente a tal variação da casa em uma espécie de natureza-morta ${ }^{96}$.

Sem embargo, se a mera consideração do poema à luz de um referente prévio ou da experiência social real é arriscada em termos genéricos, pode soar ainda muito mais imprópria no caso de um poeta como Régis, que, mesmo privilegiando procedimentos como o ready made ou a justaposição de resíduos do real, sempre se empenhou em desvencilhar as condições da experiência artística daquelas da experiência histórica. Pelo menos no que se refere ao controle da recepção crítica, tal empenho não foi infrutífero. Hansen, por exemplo, posfaciador dos dois últimos livros do poeta, insiste na barbárie, autodeformação, incongruência e despedaçamento da referência; na construção da referência pela "dramatização contínua dos procedimentos" (não há referente prévio ou exterior à leitura); na "autorreferencialidade"; na integração, refuncionalização, e transformação das linguagens brutas (publicitárias, espetaculosas e poéticas); na dessemantização do discurso pelos hiatos entre pedaços do junkspace etc.

Isso nos traz de volta ao debate sobre a dissolução referencial e a recusa mimética, a que aludimos no primeiro capítulo. Devemos indagar, porém, em face de um poema como "Casas sem dono”, sobre o grau de estranheza (transformação, refuncionalização, deformação) que a estrutura compositiva de fato introduz em relação aos pedaços de realidade de que é feita. Já nos referimos à equivocidade do "sempre dorme", à invenção das "árvores-frechais" e ao reforço da tonicidade dado pelas assonâncias, entre outras coisas, como sinais de transformação do dado bruto. Mas o que dizer do ponto de vista? De que perspectiva a cena é descrita? Que ângulo de observação é esse, que se move do farol à varanda guardando certa distância? Dissolve-se o sujeito da enunciação em enunciados constativos que se incluem "no espetáculo dos resíduos, marcando sua diferença pela autodecomposição de si mesma nos fluxos das pulsões depressivas da coisa observada" (Hansen, 2007, p. 115)? Ou haveria, em contrapartida, certa "estabilidade escópica”, indicada de modo sutil pelo deslocamento do observador, bem como por certa distância jamais franqueada? A suposta autodecomposição do discurso não seria contradita pela

\footnotetext{
${ }^{96} \mathrm{~A}$ vocação pictural da poesia de Bonvicino e o gosto pelo gênero natureza-morta são mais de uma vez apontados por João Adolfo Hansen no posfácio a Página órfã: "Bonvicino é pintor quando compõe com artifício programaticamente deformado suas naturezas-mortas". Mas se trata de uma composição feita de objetos parciais, objetos-fluxo, que evidenciam tão somente uma "falta de ser" (Hansen, 2007).
} 
integridade sinóptica do olhar? Guardemos a questão, enquanto examinamos outros poemas.

O poema seguinte a "Casas sem dono" retoma a imagem do sono público em meio ao movimento dos carros.

\author{
À TARDE \\ Quase nus \\ estirados, dormindo \\ entre pistas \\ Cabine \\ Sem vidros \\ Cabeça \\ contra a parede por um momento \\ ao lado de grafites \\ Debaixo do viaduto \\ ou sentado ainda \\ aliviar-se à sombra \\ do anúncio
}

(Céu-eclipse, p. 73)

Aqui temos um poema de feição mais tradicional, com estrofes e versos, assonâncias e aliterações (com contraste entre as semivogais "i" e "u" e repetição das consoantes " $n$ ", "r" e "d": nus/viadutos/ anúncio; dormindo/cabine/vidros/grafites) e uso de enjambements (hábil, principalmente, na passagem da primeira para a segunda estrofe, com o deslocamento do "sem vidros", que, referido à cabine, passa a qualificar também a cabeça desprotegida).

Chama igualmente a atenção, nesse novo instantâneo da situação de rua, a entrada em campo de elementos referentes ao universo comunicacional: os grafites, o anúncio e, talvez, indiretamente o telefone (da cabine avariada). É como se o desabrigo ganhasse mais uma dimensão, como se os corpos nus e sonolentos e a cabeça arriada contra a parede estivessem expostos não somente ao tráfego e às intempéries, mas também ao peso das palavras e dos signos que os circundam. Por isso, a estrofe final, em que, sob o viaduto, alguém "se alivia" à sombra do anúncio, parece especialmente bem urdida, não apenas pelo 
jogo sonoro, mas também pela sobredeterminação do alívio, que pode se referir a diferentes cargas e conectar o dejeto corporal (aliviar $=$ defecar) ao dejeto publicitário.

Vale dizer, aliás, que a contraposição entre publicidade e pobreza (gerando por vezes polarizações ingênuas, maniqueístas, denuncistas ${ }^{97}$ ), constituirá uma das linhas de força de Página órfã (2007), livro que comentaremos em seguida. Mas antes vejamos outro poema de Céu-eclipse, especialmente dedicado à descrição dos dispositivos antimendigos em ação nas megalópoles contemporâneas.

\section{COMPOSIÇÃO}

Cano com furos equidistantes fixo no teto lançando jatos de água destilada lance de paralelepípedos desalinhado ninguém neles se ajustando grades de ferro pontiagudas em parapeitos de vitrine e janela de alcance mínimo para que ninguém se deite nos espaços vazios ferros retorcidos em portas no teatro além dos jatos câmera canteiro árvore de onde sai a água flores vaso espinho

\section{(Céu-eclipse, p. 77)}

Mais uma vez estamos diante de um bloco de texto em prosa, sem nenhum sinal de pontuação, um longo rol que vai do cano aos jatos de água, aos paralelepípedos, grades, ferros... até o espinho final, que de certa maneira condensa a função adversativa dos elementos precedentes. Porém, afora a estranheza do final, em que se aglutinam vários substantivos (jatos/câmera/canteiro/árvore; água/flores/vaso espinho) como se a descrição se acelerasse, e a água destilada ${ }^{98}$, que parece sair da árvore como o espinho sai das flores, o restante do poema soa muito colado à realidade desses dispositivos concebidos para que "ninguém se ajuste", "ninguém se deite". A sensação que se tem, em certa medida, é a de um mimetismo frouxo que não atina com a especificidade desses ninguéns, tampouco com

\footnotetext{
${ }^{97}$ A esse respeito, observa Simon (2008, p. 161): “Cenas e imagens irrompem (ou nos atacam) esquematicamente, como numa peça publicitária ou de agit-prop: a máquina de contrastes dos poemas está sempre equiparando sujeira e consumo, selvageria e técnica, top models e mendigos [...] Noutras palavras, o resultado lamentável de uma era de globalização e neoliberalismo se converte por um reducionismo gritante em Página órfã na contraposição da desgraça dos pobres à obscenidade escandalosa dos ricos e famosos, contraposição que se repete vezes sem conta - o que é muito pouco para uma poesia política que ainda apregoa dialogar com a Language Poetry".

${ }^{98}$ Constituiria a água destilada, "purificada", sem sais, um símbolo da lógica higienista que preside o funcionamento dos dispositivos antimendigo? Seriam necessários mais elementos para apoiar tal hipótese, mas, se a julgarmos ao menos plausível, é como se a água destilada representasse, ao mesmo tempo, o meio para purificar as ruas e a figuração do resultado produzido por tal operação.
} 
a razão por detrás da hostilidade desses dispositivos, a fonte de onde jorra o esguichoespinho, guardião de teatros e vitrines.

Tal sensação se intensifica nos poemas de Página órfã, que retomam o tema dos mendigos ao relento, entre os carros, a publicidade e o lixo. Neles, frequentemente, o recurso aos resíduos textuais da cidade (pedaços de outdoor, slogans, frases de grafite) tenta compensar a falta de mediação no empilhamento de imagens sórdidas como uma espécie de interpretante da fúria antidiscursiva. É o que ocorre, por exemplo, em "De manhã", poema em que novamente aparecem os mendigos no "canteiro central da avenida", em sofás, entre carros de marca, reciclando lixo, separando sobras, fumando, tomando cajuína - cena bastante semelhante às descritas nos poemas que vimos, com mais detalhes talvez na descrição das ações e organização sintática mais convencional. O poema se fecha com a menção ao que está escrito em uma das vigas do viaduto sob o qual habitam os mendigos: "Vida insana,/ infernal, promíscua".

Mas qual o sentido desse fecho? O que ele revela? Trata-se de uma legenda explicativa para toda a cena? Uma legenda que exprime uma possível autoconsciência dos mendigos sobre a sua "aviltada" condição ou a visão de um espectador externo, apartado da pobreza e do lixo? Ou ainda a visão da própria cidade, já que se trata de um texto inscrito em seus muros, que o poeta se limita a recolher? No entanto, tal legenda também não confirma em grande parte o senso comum? Que surpresa ela suscita em face da descrição que a precede? Tais questões de certo modo se relacionam com a distância de observação presente nesses poemas, com a integridade sinóptica que preside as descrições e com um tipo de abordagem em que, como escrevi em outra ocasião, "não há propriamente deslocamento ou cisão da voz lírica [...] - ela não assume o ponto de vista daqueles a quem retrata, nem se instabiliza radicalmente a ponto de prescindir de pausas epifânicas" (Weintraub, 2007, p. 7).

Vejamos, porém, outro poema de Página órfã , no qual a descrição das cenas de rua se mescla à écfrase de obras pertencentes ao campo das artes plásticas.

\section{MORADORES}

Na ponta do túnel, numa de suas saídas para a avenida de edifícios altos, 
onde há um canto,

pintado na parede

um detalhe de Retirantes, de Candido

Portinari, óleo sobre concreto

uma lâmpada no teto,

os carros transitam sem parar

a mãe e seu bebê sentados

numa caixa de madeira

ao lado

um pescoço de

manequim feminino decepado -

um volume cinza

cinza talvez da tinta da caveira do bebê

no colo da mãe decora

a sala de visitas ao meio-dia

um sofá, real, verdadeiro

um par de caixas feito de cadeira

e mesa ao mesmo tempo

onde se compartilha monóxido

de carbono, aqui um homem vadio

se dedica ao ócio

passageiros dos carros atiram

pontas de cigarro

na calça jeans e na blusa rosa

pendurados

nas tábuas soltas

de um armário

varais

a lua cheia no quadro,

outra caveira no colo do pai?

(Página órfã , p. 57)

O cruzamento entre a representação plástica do grafite (e do quadro a que ele alude) e a representação verbal do poema desempenha importante papel em uma obra cujos versos almejam emular a vocação transgressiva dos grafiteiros e pichadores, geralmente jovens da periferia, que testemunham a desigualdade social e desafiam a propriedade espalhando suas inscrições pelos muros da cidade privatizada.

Tereza Caldeira (2012) procura distinguir a pichação do grafite, destacando o caráter mais subversivo da primeira forma de intervenção. À diferença dos grafites, de teor artístico, muitas vezes realizados sob os auspícios da municipalidade e até com patrocínio da iniciativa privada, as pichações são coibidas pela polícia e malvistas pela população, que 
as considera vandalismo. Explica Caldeira que, para os pichadores, no entanto, "suas intervenções expõem as características de um espaço público ao qual dispõem de poucas formas de acesso e no qual se sentem forçados a impor sua presença" (Caldeira, 2012, p. 39).

A fim de contextualizar um pouco melhor o uso ecfrástico do grafite em "Moradores", vale dizer que o poema se refere a um grafite que recobriu a parede do túnel que liga as avenidas Dr. Arnaldo e Rebouças à Paulista. Ele fazia parte do projeto "Modernistas na Paulista", realizado em 2004 pela ONG Revolucionarte, em parceria com a Secretaria das Subprefeituras da Capital e os Centros Educacionais Unificados (CEUs). Tal projeto estampava nas paredes do túnel reproduções de telas de pintores modernistas (Tarsila do Amaral, Di Cavalvanti, Portinari) feitas por jovens do CEU Paz (em Brasilândia, Zona Norte da cidade), alunos de cursos de pintura com aerógrafo. O objetivo era duplo: profissionalizar pichadores e grafiteiros e, ao mesmo tempo, levar a arte brasileira para as ruas a fim de "preservar o patrimônio público contra a depredação".

Guy Amado (2007) teceu críticas ao projeto, encarando-o como mais um exemplo de cooptação do grafite que, com o álibi de oferecer às massas o biscoito fino dos museus, termina por: a) falsificar a experiência de contato com as obras por meio de réplicas fora de escala, distorcidas e plasticamente pasteurizadas, b) desvirtuar a linguagem do grafite transformando-o em um híbrido mais próximo da pintura mural, c) garantir a aceitação social desse tipo de intervenção, submetendo-a às convenções elitistas da pintura "canônica".

Claro que as circunstâncias de produção da imagem de que os versos se apropriam não determinam de per si o caráter do poema. O caráter domesticado, demagógico e populista do grafite, que por sua vez evoca um dos ícones mais oficiais da representação da pobreza em chave realista, poderia ter sido subvertido na écfrase poética. Sem embargo, ao aproximar os retirantes retratados pelo pintor de Brodowski dos moradores de rua no Brasil contemporâneo, como o poema lida com a carga ideológica da referência pictórica de base?

A cena explora novamente a justaposição entre a intimidade doméstica e os carros, os móveis feitos de improviso e destroços, o manequim decepado etc. A diferença em relação aos poemas precedentes fica por conta da associação entre as imagens cadavéricas da tela de Portinari e as caveiras no colo dessa família ao relento. O cinza do grafite 
confunde-se com o cinza das pessoas sob a fuligem, e o penoso êxodo dos retirantes nordestinos se sobrepõe ao desabrigo dos mendigos.

No entanto, o poema, ao mesmo tempo em que tira partido da fusão entre as duas imagens, a da família pintada e a da família entre os carros, não abre mão das distinções ao qualificar o sofá como "real, verdadeiro", o que se opõe a lua cheia "no quadro". Trata-se então de um reagenciamento comedido das referências prévias, já que o "real" dessa poesia não se instaura de modo completo, não prescinde de reassegurar-se do real verdadeiro, exterior. Isso aparece de modo ainda mais emblemático no trecho que menciona o homem "vadio", que "se dedica ao ócio". Quem fala? De que ponto de vista? Contrariando talvez a distância compassiva com que se contempla a vulnerabilidade dessa gente exposta aos carros e às pontas de cigarro, o vadio aqui, em acepção mais moral que cinética, deambulatória, não trai adesão ao discurso estigmatizador das classes dominantes? Para além da rima toante entre ócio e monóxido, não haverá certa consonância ideológica com a visão que associa o olho da rua à indolência, a desocupação à falta de empenho? Será mesmo possível insistir na dissolvência do sujeito da enunciação diante de tão ostensiva marca de classe?

Outros poemas poderiam ser mencionados, mas creio que a amostra analisada até o momento é suficientemente representativa do tratamento dado por Bonvicino aos moradores em situação de rua. Destacam-se como pontos recorrentes: a) a prevalência de composições de natureza descritiva, apoiadas fortemente no contraste entre intimidade e exposição, b) a exploração das imagens de torpor, em uma possível simplificação das contradições que marcam a situação de rua, c) o recurso a um tipo de construção aparentemente fragmentada (muitas vezes com supressão de verbos e pontuação), montagem de flashes de um observador que zanza por calçadas, mocós e viadutos, de um lado, e, de outro, certa estabilidade do ponto de vista e da distância de observação (condicionados à posição de classe), que acabam por reproduzir, nos detalhes, estereótipos da pobreza. 


\section{Tarso de Melo e a pobreza obturada}

Outro poeta que se debruça com interesse sobre os moradores de rua é Tarso de Melo, principalmente em Lugar algum (2005) e Exames de rotina (2008).

Em Lugar algum, mendigos e pedintes são presença constante, sobretudo nas seções "Por nada" e "Era de aquário". Ainda que, em certos momentos, tal presença seja esvaziada pela transfiguração metalinguística (como no poema de abertura, em que a rua se "literatiza" e o poeta desaparece "viela das letras adentro"), há também várias passagens que flagram aspectos contraditórios da condição da rua e da relação dos desabrigados com os observadores que com eles dividem o espaço público. Vamos a eles.

\section{THEATRUM MUNDI}

a tampa é erguida um pouco, apenas até ser possível ver se ao redor está seguro: tudo limpo, a tampa é deslizada para o lado e a cabeça toda já pode visitar o ar lá fora até ganhar confiança; um braço puxa o corpo (os olhos bem abertos) e o outro já prepara a manobra que levará a perna até o nível da calçada; para a outra, ficou mais fácil, mesmo mantendo a cabeça (os olhos bem abertos) e o corpo todo rente às ondas de pedra do calçadão até o próximo ato: rastejar e apenas levantar o corpo quando for certo que está intacto; tudo feito, é bom que o lar (os olhos, a tampa) seja lacrado

\section{(Lugar algum, p. 33)}

"Theatrum mundi" revela uma faceta menos conhecida do morar em crise: a habitação do subsolo, nas galerias pluviais e tubulações do esgoto, que tem parentesco tanto com o clima kafkiano de um conto como "A construção" quanto com a vida real dos homens-barata nas grandes cidades brasileiras. ${ }^{99}$

\footnotetext{
${ }^{99}$ Notícias sobre moradores "em condição de esgoto" são veiculadas de tempos em tempos nas páginas dos grandes jornais. Ver, por exemplo, Ribeiro (1994), Torres (1997) e Wainer (2005).
} 
O poema explora a imagem do esconderijo subterrâneo em uma circunstância de intenso perigo. Esconderijo do qual é preciso sair com o máximo de cuidado, feito um bicho que teme ser capturado e se move lentamente, parte por parte, até "ganhar confiança”, mantendo, no entanto, "os olhos bem abertos”, expressão que aparece duas vezes, destacada por meio de parênteses. O movimento dificultoso do ser rastejante que almeja o "ar de fora" (como quem de algum modo sufocasse) teme também as "ondas de pedra do calçadão", que podem evocar simultaneamente o desenho do pavimento e a sensação de que ele se agita de maneira ameaçadora. Esse solo movediço e todo o esforço de saída do inframundo podem ferir ou despedaçar um corpo pisável, que por isso não se ergue sem a certeza de estar intacto. A magnitude do perigo é então sugerida pelo montante de manobras destinadas à verificação de que é possível sair, passar, erguer-se e penetrar em um território de algum modo estrangeiro, sem salvo-conduto.

Mas todo esse cuidado contra as ameaças ao rés do chão revela, ao final, que a vida a preservar tem intimidade com a morte. O "lar lacrado" (paronomásia engenhosa, em que o substantivo se entranha no adjetivo) traz uma nota de horror, já que a tampa parece cobrir não apenas o buraco de onde se saiu, mas também os olhos, antes bem abertos. Corpo e casa se confundem, portanto, nesse espaço pré-tumular.

A exploração dos aspectos "tanáticos" da condição de rua, da proximidade entre o morar e o morrer, ressurge de maneira mais explícita e violenta no poema "Casa-vala", do livro Exames de rotina.

\section{CASA-VALA}

pneus cortam o telhado, aves de aço cantam alto sobre a cabeça do enterrado vivo: enquanto chove, enquanto a fuligem serena, enquanto o sol espanca $\mathrm{o}$ asfalto, as vitrines, o meio-dia é nosso silêncio : ali onde ninguém mora, onde ninguém vive, o dia passa como um trator sobre a paisagem

\section{(Exames de rotina, p. 17)}

Nessa casa-vala, em que o telhado de uns é a autopista de outros, nesse mundo às avessas, que converte o chão em teto, nada subsiste da paz dos cemitérios. Destaca-se a hostilidade dos elementos que compõem o entorno: o sol espancador, o dia-trator, o ruído 
dos carros e aviões passando sobre o enterrado vivo, o "ninguém" que vive e mora onde tudo esmaga e corta.

Nota-se aqui também a presença de rimas internas, assonâncias e aliterações (telhado/enterrado; aço/alto/asfalto; fuligem/paisagem), certa regularidade métrica nos versos longos, com extensão entre onze e quinze sílabas, e o papel estruturante da anáfora (“enquanto" chove/serena/espanca, “onde ninguém” mora/vive).

A expressão "enterrado vivo", título de um poema de Drummond em Fazendeiro do ar (1954), aflora com sua carga de grotesco reforçada por outros poemas do livro, como "Fóssil", em que os mendigos são descritos inicialmente como "pedras fundidas à calçada", impressão corrigida em seguida pela constatação de que "algo respira embaixo, dentro, através dessa carcaça” (Exames de rotina, p. 15). Se em "Casa-vala", poema diurno, os enterrados vivos são achatados pelo dia, pelo sol e pelos carros, em "Fóssil", poema noturno, eles retornam como pedras, carcaças, peças de carne, cuja vida obliterada (extinta e vestigial) só se manifesta “depois do último trem, dos últimos/ passos, dos últimos olhos e medos e sustos passarem".

A imagem da cidade deserta em que os fósseis voltam à vida ressurge em "Outro fóssil" (Exames de rotina, p. 21), poema que parece tratar do esvaziamento de áreas cuja vida se restringe às atividades produtivas desenvolvidas "em horário comercial". A essa vida produtiva, opõe-se a vida dos ratos e dos moradores de rua "esquecidos na fuga, incrustados na carcaça do bairro,/ presos agora aos inúteis anúncios de passa-se o ponto".

O cenário tem algo de catástrofe e ruína: o fim da jornada de trabalho é descrito como fuga, destruição ao fim da qual sobra apenas a carcaça do bairro abandonado, esvaziado até por meio dos anúncios, que sinalizam a saída, o encerramento das atividades ("passa-se o ponto"). Nesse cenário, a caracterização dos que perderam a corrida, o emprego, o lar é curiosa, porque se contrapõe à ideia de mobilidade e errância: eles ficam incrustados na carcaça, presos ao ponto que se vende/passa.

Vemos então uma cadeia associativa que percorre todos esses poemas, indo da tampa ao trator e deste ao fóssil-carcaça, que, mesmo ao rés do chão, deve vir à tona de si.

Mas e quanto à perspectiva de observação neles adotada? O ponto de vista é distanciado, sinóptico e invariável ao longo dos poemas, como em Bonvicino? Há 
dissipação naturalista nas descrições? Por que tipo de mediação subjetiva passam os dados brutos da realidade?

No primeiro poema, a descrição minuciosa da mecânica gestual, passo a passo, membro a membro, não presentifica para o leitor o esgueirar-se da "personagem", sua emersão anabásica, tolhida pelo medo? O close sobre esse corpo rente às ondas do calçadão não indica uma atitude de certo modo empática, um observador que se aproxima a ponto de assumir o ângulo de visão do habitante subterrâneo?

E em "Casa-vala", a perspectiva é a mesma? A quem se refere o possessivo "nosso" a qualificar o silêncio que se opõe ao barulho dos pneus, à infiltração da chuva e da fuligem, aos golpes do sol? Trata-se de um ponto de observação recuado em relação ao “ali” em que vivem os ninguéns soterrados? A descrição é chapada ou tira partido do contraste entre esse silêncio e certa progressão na violência ambiente, associada sobretudo à prosopopeia do sol que espanca e do dia que aplaina os viventes como um trator?

De modo similar, nos poemas sobre fósseis urbanos, há também transfiguração do dado bruto pela metáfora paleontológica, transmissão da carcaça do corpo ao bairro e, ao mesmo tempo, percepção das condições que engendram o desalento (o dia solar e industrioso, a noite de esvaziamento e fuga, a restrição da vida ao campo do trabalho, os anúncios de fracasso econômico etc.), que é desse modo desnaturalizado, apesar da natureza biológica da metáfora que o reveste.

O descritivismo nesses poemas de Melo é, pois, como procuramos sugerir, temperado por surpresas como a perspectiva aproximada (ou mesmo adesão ao ponto de vista das personagens), a identificação entre corpo e toca (ambos lacrados), o recurso desimpedido à metáfora, como ocorre no exemplo do dia-trator e no da fossilização de homens e bairros, que equipara hiperbolicamente improdutividade e extinção.

Voltemos, porém, a "Theatrum mundi", cujo título retoma o velho tópos do mundo como teatro. Segundo E. R. Curtius (1996), tal metáfora remonta a Platão, é glosada algumas vezes durante a Idade Média, adquire força a partir da lenta ruptura dos ideais renascentistas e assume lugar de relevo no século XVII, como se pode ver na obra de Shakespeare e na de Calderón de la Barca, seja em uma vertente mais cética ("Life's but a walking shadow, a poor player/ That struts and frets his hour upon the stage...", Macbeth, 
$\mathrm{V}, 5$ ), seja em chave teocêntrica, em que a comédia humana segue à risca, frequentemente sem dele desconfiar, o divino script.

Remonta também ao século XVII a noção de espaço público como "teatro da civilidade", um domínio de sociabilidade oposto à família, onde cada um porta uma máscara e pratica um jogo compatível com sua posição social. Como explica Sennett (1988), com o advento do romantismo, essa teatralidade citadina, que alivia o encontro público do peso do eu e da qual depende a ação política, será desqualificada como hipocrisia. Em seu lugar surgirão o ideal intersubjetivo como comunidade afetiva e o culto à personalidade, à confissão, à decifração do Outro, a redução das qualidades políticas à sinceridade e ao carisma.

Fugiria ao nosso propósito acompanhar as etapas dessa passagem da teatralidade mundana para a encenação da intimidade, que atravessa o romantismo, chega ao século XX e se estende aos dias de hoje, desembocando na grotesquerie dos reality shows contemporâneos. Tal digressão foi motivada apenas pelo fato de que essas formas contrastantes de teatralidade são habilmente evocadas por Melo em Lugar algum. Não por acaso, ao poema "Theatrum mundi" segue-se um intitulado "Home theater".

\section{HOME THEATER}

repare como funciona: o manobrista abre a porta e um sorriso, o porteiro abre outro e outra porta, e diversas portas e sorrisos se sucedem da vitrine para dentro: boa-tarde, como-vai, abraços à distinta-(mesmo que desconhecida)-família: dão-se as cartas, feitas as apresentações, então, às compras: divino, ótimas, fantástica, lindos - vai levar, basta dizer quanto é, o plástico faz o resto

até-logo; na contramão, salva de sorrisos e portas que se abrem, o porteiro abre um e a porta, o manobrista abre outro e blinda a última porta: repare como funciona

(Lugar algum, p. 34)

Do "lar lacrado" em que vive o homem-barata ao abre e fecha de portas e sorrisos nos templos blindados do consumo (espaços homogêneos quanto à composição de classe, 
imantados por uma intimidade postiça), o maquinismo que regula as trocas intersubjetivas parece definido pela mesma lógica. A decomposição do gesto anteriormente observada em "Theatrum mundi", o que se poderia chamar de uma "mecânica do medo", que eleva o impulso de autopreservação a níveis paroxísticos, reaparece em "Home theater" de outro modo. O teatro em ambos os poemas é aquele dos draminúsculos à maneira beckettiana: ação reduzida e movimentos truncados, repetitivos, estereotipados. A estrutura especular do segundo poema, em que os mesmos gestos se realizam "da vitrine para dentro" e depois, "na contramão", com fecho idêntico à abertura ("repare como funciona"), talvez também possa ser interpretada como um equivalente da sociabilidade retratada no poema, em que não há encontro ou interação propriamente ditos, mas apenas uma sucessão de automatismos sociais, espécie de mise en abyme de imagens como as que vemos ao defrontar dois espelhos.

À primeira vista, o "repare como funciona" parece confirmar esse fluxo ininterrupto no qual nada emperra, tudo desliza, funciona, dá certo, sem pergunta, surpresa ou atrito. Aqui e ali há sinais de certa força a azeitar as engrenagens a fim de garantir seu bom funcionamento, conforme demonstram expressões como "dar as cartas" (dominar, ficar por cima) e "salva de sorrisos".

Mas quem exatamente profere o "repare"? Trata-se da fala do vendedor, demonstrando as virtudes da mercadoria (o equipamento de home theather), ou de uma exortação ao leitor, intimado a observar a engrenagem de rapapés e o funcionamento do poema que a representa? O imperativo provém do interior dos espaços de consumo e repetição ou constitui um dado de estranheza, que engripa o automatismo, trazendo-o de modo enfático à consciência? É difícil responder com segurança a tais perguntas nesse poema em que a pronominalização verbal (sucedem-se sorrisos, dão-se as cartas, abrem-se portas) indetermina reiteradamente o sujeito. De todo modo, vale notar como a ideia do lacre e da blindagem, presente nesses dois "teatros", opera de modos distintos e aparentemente antagônicos. No primeiro poema, a imagem da toca subterrânea constitui uma variante do morar em que é máxima a exposição do inquilino, dada a falta de mediação entre o espaço doméstico e a rua, e a tampa (sobre a toca e o corpo) se associa a uma restrição do movimento, ao gesto tolhido, fracionado. No segundo, em que a mediação é máxima e o exterior convivial fica cancelado pelo ensimesmamento consumista, entre 
portas e sorrisos, o que se destaca é o automatismo sem freios, que iguala mão e contramão e também parece aprisionar o sujeito em um contínuo deslizamento.

Ainda no que concerne às imagens de exposição e enclausuramento em jogo tanto na situação de rua como nas fortalezas plastificadas onde se encerram as classes dominantes, vejamos um último poema de Melo, também do livro Lugar algum, em que o desabrigo é abordado por meio do encontro interclasses.

\author{
QUATRO \\ nos cantos mais escuros, \\ parece que tudo se acomoda \\ melhor, plena noite, \\ a lua ignorada, o poste \\ não chega a tingir \\ com seus raios \\ a quina mais estranha \\ de quem passa sobre \\ ou sob o viaduto \\ os carros que o poste \\ com um aceno vermelho \\ faz parar à porta \\ do dormitório \\ fingem desviar o olhar \\ enquanto seus vidros \\ negros sobem \\ pois as crianças estão \\ ainda e sempre \\ acordadas
} (Lugar algum, p. 60)

O poema faz parte da terceira seção do livro, com uma série de poemas numerados sobre famintos, pedintes, artistas de rua (malabaristas, homens-estátua, músicos velhos), transexuais e aleijados. "Por nada", título dado à seção, talvez revele o denominador comum entre todas essas personagens, a vida "de favor" e a compulsão a agradecer a 
caridade dos concidadãos, contrafação de justiça, os inúmeros "obrigados" acoplados à sua resposta-padrão ("por nada" ou "de nada"). Ao mesmo tempo, a expressão também parece designar, em sentido oposto, alguma resistência a essa ordem de coisas, tal como se vê na epígrafe de abertura, constituída pelos versos de Joseph Brodsky: “Se gritarem 'Ei, tu aí!' não te dês por achado. Sê surdo e mudo./ Mesmo que saibas a língua, não abras a boca por nada deste mundo" (grifo meu).

Mas vamos ao poema, que retoma a imagem do morador de rua sob o viaduto, acomodado na escuridão, na "quina estranha" a salvo do luar e da luz do poste. Quina-dormitório, diante da qual os semáforos acenam e os carros desviam o olhar (de novo o recurso à prosopopeia) e sobem os negros vidros para obliterar o que as crianças, acordadas, não podem ou não devem ver.

O fecho da composição tira partido de certa indeterminação das crianças, que, em uma leitura apressada, pode suscitar a pergunta: de que lado do vidro elas estão? Trata-se de crianças no interior do carro, que não devem ser confrontadas com o espetáculo da miséria, ou dos menores de rua, cujo olhar em eterna vigília os motoristas evitam? O "ainda e sempre/ acordadas" inclina a resposta para a segunda opção, que desmente o movimento de acomodação sugerido na primeira estrofe. É ilusória a impressão de que à noite as coisas na rua se acomodam melhor, pois, para quem vive ao relento, exposto à violência contínua, a noite é um período de maior perigo, quando escasseiam as testemunhas e aumentam as agressões. Não por acaso, parte significativa da população de rua prefere dormir durante o dia, "protegida" pela agitação citadina. Assim, tudo indica que as crianças que não se deixam ninar, sob pena de dormir para sempre, são muito provavelmente as habitantes da quina insone perante a qual é preciso fechar olhos, vidros e ouvidos, em um regime de distribuição da atenção que impõe a uns alerta redobrado e a outros, o conforto da cegueira.

À semelhança do que vimos ocorrer nos poemas anteriores, o ímpeto descritivo é contrabalançado, de certa maneira, por uma reviravolta narrativa, que desloca ou inverte a expectativa criada pelo poema. Em “Quatro", essa reviravolta é suscitada pelo contraste entre a acomodação da primeira estrofe e a percepção traumática das crianças acordadas, que deve ser recalcada. Em "Theatrum mundi", esse "elemento-surpresa" é dado pela associação entre corpo e casa, olho e tampa; em "Casa-vala", ainda que não haja propriamente reviravolta, a surpresa se liga a certo acúmulo metafórico em direção ao dia- 
-trator. Por fim, em "Fóssil" e "Outro fóssil", ela advém do movimento do que parecia inerte ou, inversamente, da cristalização da vida (os moradores incrustados na carcaça do bairro comercial).

Trata-se, portanto, de um modo de figurar a situação de rua muito distante das naturezas-mortas de Bonvicino, em que a descrição, como já dissemos, não parece implicar nenhum tipo de transformação ou problematização do ponto de vista. Nos poemas de Melo, em contrapartida, vemos não apenas retificação, mas variedade de perspectivas de observação (que alterna planos abertos a closes por adesão ao ponto de vista da “personagem”) e procedimentos (decupagem ou aceleração/automatismo da gestualidade urbana, progressão metafórica, repetições, espelhismos etc.).

\section{Arrematando}

Muitos outros exemplos, de autores diversos, poderiam ser aqui incluídos. Nossa pretensão, porém, não foi a de exaurir um problema complexíssimo, considerando-o sob todos os aspectos. Em vez disso, procuramos eleger obras sinalizadoras do já referido "retorno ao real" (Simon, 2008), buscando indícios de assimilação poética da crise habitacional provocada pela falta ou ineficiência de políticas públicas de provisão de moradia a partir dos anos 1980, com incremento da segregação espacial da pobreza na produção social do ambiente urbano.

Levantamos de início a hipótese de que talvez fosse possível encontrar nesses poemas o testemunho de um novo padrão da tragédia urbana brasileira ou de novos modos de encarar o problema da moradia que, em alguma medida, distinguir-se-iam daqueles que encontramos na poesia brasileira escrita ao longo do século passado, bem como em peças do cancioneiro popular escritas por compositores como Orestes Barbosa, Noel Rosa, Herivelto Martins, Cartola e Adoniran Barbosa, que também se dedicaram a tal temática. Vejamos então se tal hipótese se confirma com base nos comentários e análises feitos até aqui.

Com relação ao cancioneiro popular, é temerário arriscar generalizações sobre um vasto conjunto de obras díspares, mas é possível depreender, em muitas das canções sobre a moradia precária e a cidade ilegal, certo lirismo compensatório em relação à pobreza. Ele 
pode aflorar de modo mais explícito nos tetos furados que salpicam de estrelas nosso chão, nos morros mal vestidos em que "é sempre feriado nacional", em que "ninguém chora, não há tristeza/ ninguém sente dissabor”. Mesmo em compositores com inclinação mais crítica e satírica, como Noel Rosa, a imagem do desabrigo designa condição muito diversa da que hoje define a população em situação de rua. É o caso de "O orvalho vem caindo", de Noel Rosa. Grande sucesso no carnaval de 1934, essa canção oferece uma imagem simpática da vida desprotegida, em que o "passar mal", sofrendo a fome e as intempéries, implica decerto ironia ao mundo do trabalho ("A minha terra dá banana e aipim/ Meu trabalho é achar quem descasque por mim") e aos representantes da ordem ("meu despertador é o guarda-civil"). É enorme, portanto, a distância entre esse guarda despertador e os agentes de extermínio que desnudam o útero citadino, libertando-o da mulher que o cercava e o preenchia abrindo-se a invasores, conforme se lê no poema do cupim, de Pádua Fernandes. Assim como é enorme a distância entre o prazer dos que dispensam a felicidade de arranha-céu por já viverem "pertinho do céu” e os infrasseres de Tarso de Melo, cobertos não por orvalho, mas por tampas e tratores, camadas e camadas de sedimento e abandono.

E, ainda quando o termo de comparação adota uma perspectiva mais pessimista e próxima do drama habitacional contemporâneo, como ocorre nas composições de Adoniran sobre despejo ("Despejo na favela" e "Saudosa maloca"), a distância em relação ao que se vê nos poemas examinados continua muito grande, pois já não se trata de flagrar a revolta, a impotência ou o conformismo ante a "ordem superior" dos donos, dos senhores, dos doutores. Quando a cidade ilegal se dissemina, quando o despejo, o desabamento ou a vida ao relento passam a ser o único destino reservado aos que têm tão pouco que podem levar a mudança "no bolso de trás", já não é possível pegar "as paia nas grama do jardim” e cantar para esquecer, nem se fiar na esperança de arrumar qualquer outro canto, pois todos os cantos se tornaram, para eles, perigosos e proibidos em uma cidade que defende seus vazios e "repõe” os espaços "usurpados" com o máximo de violência. ${ }^{100}$

\footnotetext{
${ }^{100}$ A distância também se liga à derrocada de certa ideia de legalismo para a qual José Paulo Paes (1983) já havia chamado a atenção na obra de Adoniran. Tomando como base a canção "Abrigo de vagabundo", Paes destaca, na obra do sambista, a "aceitação das leis da propriedade", que "leva o trabalhador a orgulhar-se do seu trabalho, ainda que injustamente remunerado; a erguer com as próprias mãos uma casa para si e para os seus, mesmo que ela não passe de uma maloca, a buscar nas instituições legais, por discriminatórias ou corrompidas que sejam, uma forma qualquer de segurança." (Paes, 1983, p. 178). Interpretação diversa do samba é oferecida por Wilson Flores (2011), que chama a atenção para as ambiguidades e ambivalências da letra em que se revela a penúria financeira e de direitos de quem constrói a casa própria sem planta, dependendo dos favores do fiscal da prefeitura; trata-se, pois, de um legalismo meio torto e de um elogio do trabalho que não garante direitos, nem segurança, nem dignidade.
} 
Alguém poderá perguntar por que a comparação entre a poesia pós-1990 e a música popular não recorre a manifestações mais contemporâneas, como o rap. Acontece que, mesmo sem uma pesquisa sistemática a esse respeito, a impressão que se tem é a de que, ao contrário do tema da violência, a questão habitacional não ocupa lugar de relevo nas letras de rap. Isso talvez se ligue ao fato de que muitos dos artistas do hip-hop, sendo filhos de trabalhadores pobres que se estabeleceram na periferia e acompanharam as lutas dos movimentos sociais dos anos 1970 e 1980 por direitos e inclusão social, enxergam com ceticismo a capacidade inclusiva da democracia brasileira, especialmente no que se refere à população negra. Enquanto seus pais procuraram alterar o modo pelo qual eram encarados pela elite, sem questionar os valores dessa mesma elite (como o direito de propriedade, motor da luta habitacional), os arautos do rap percebem de maneira clara os limites das instituições democráticas que, assegurando precariamente alguns direitos políticos e sociais, como o direito à moradia, não diminuíram a vulnerabilidade da população pobre (o que depende da proteção aos direitos civis e individuais), razão pela qual as letras de rap testemunham uma atitude de insulamento e descrença em face dos discursos oficiais sobre justiça. Afirma a esse propósito Teresa Caldeira (2011, p. 318):

Eles pensam a periferia como um mundo à parte, algo similar ao gueto norte-americano, um imaginário que nunca foi utilizado antes no Brasil para pensar as periferias. Além disso, democracia não é uma palavra do seu léxico; é de fato uma noção que pertence ao outro lado, ao lado da sociedade branca e rica. Suas evocações de justiça não são necessariamente feitas em termos de cidadania e estado de direito - como eram a dos movimentos sociais (e, nesse sentido, seus clamores por justiça têm, por vezes, uma preocupante similaridade com o modo como os comandos do crime organizado usam os mesmos preceitos). (Caldeira, 2011, p. 318)

Saindo do campo das canções para o da poesia escrita, em que a comparação é mais pertinente, as diferenças no tratamento do tema também se fazem notar. Se em muitos exemplos da poesia pregressa a configuração do habitar em crise explorava o contraste entre a cidade legal e a ilegal e entre diferentes posições de classe em disputa por território 
urbano, nos poemas aqui examinados tal correlação passa a ocupar o primeiro plano. Em "Favelário nacional”, Drummond já contrapunha a segregação da pobreza (“o que se passa no morro é um passar diferente,/ dor própria, código fechado: Não se meta,/ paisano dos baixos da Zona Sul.// Tua dignidade é teu isolamento por cima da gente.”) à comunhão interclasses na catástrofe ("Um dia, possivelmente madrugada de trovões,/ virá tudo de roldão/ sobre nossas ultra, semi ou nada civilizadas cabeças/ espectadoras/ e as classes se unirão entre os escombros."), ficcionalizando, porém, de modo predominante, a voz da pobreza. Depois da abertura em primeira pessoa, com laivos retóricos autoconscientes, que se pluraliza no segundo poema, mantendo a perspectiva distanciada ("nossas cabeças" $\times$ “toda a gente lá em cima”), passa-se à terceira pessoa dos discursos políticos e urbanísticos em "Urbaniza-se? Remove-se". Em seguida, há uma série de poemas que vão assumir a voz dos moradores do morro, às voltas com o lixo, a fome, a alternativa lúgubre dos conjuntos habitacionais ("Sabedoria" e "Desfavelado"). No último terço de poemas que compõem a suíte, a perspectiva de novo se generaliza e se afasta para considerar a disseminação das favelas pelo país (“Aqui, ali, por toda a parte") e pelo planeta ("Dentro de nós"), a ausência de um efetivo contraponto urbanístico à cidade ilegal ("Por que não urbanizam antes a cidade?/ Era tão bom que houvesse uma cidade/ na cidade lá embaixo"), o nexo entre progresso e favelização, entre outras coisas. De toda maneira, a voz dos agentes segregadores parece menos bem representada que a de suas vítimas.

Em Fernandes, o arremedo das vozes proprietárias aparece na erotização/esterilização da cidade-fêmea, que mobiliza expedientes da poesia barroca, modernista, concretista, misturando medidas e formas clássicas (redondilhas, sonetos) a excertos de prosa a fim de marcar diferentes dicções no concerto da segregação territorial.

Já nos poemas de Bonvicino e Melo, a condição de rua é descrita em seus aspectos mais dramáticos, de um ponto de vista que, de modo geral, não chega a satirizar os ódios e temores dos "donos da cidade", que engendram e combatem essas formas residuais de moradia. De um lado, em Bonvicino, vimos como o descritivismo enumerativo, a tendência ao gênero natureza-morta e a montagem de flashes da rua, com ênfase em aspectos abjetos (lixo, morte sujeira) ligados ao desmantelamento da intimidade, associam-se a certa estabilidade na observação da pobreza, que não explicita nem problematiza os 
condicionantes do ponto de vista adotado (embora às vezes ele se deixe trair, em uma mescla contraditória de simpatia e preconceito em relação aos deserdados da pólis).

De outro, em Melo, conquanto em alguns momentos a figuração do desabrigo enverede para um tipo de esvaziamento metalinguístico, propenso a clichês líricos, o que se logra com frequência é a mobilização de recursos como a progressão metafórica, a encenação de automatismos sociais e dribles nas expectativas do leitor, revelando mobilidade descritiva e ímpeto formalizador afeito aos diversos aspectos do morar em crise.

Terminamos assim nosso breve périplo com a esperança de haver contribuído para sugerir alguns dos impasses e soluções encontrados por alguns poetas contemporâneos no enfrentamento de um problema que, remontando às origens do processo de urbanização no Brasil, atinge no momento presente formas paroxísticas, para as quais cumpre inventar novos modos de ver, conhecer e nomear. 


\title{
Capítulo 4. Cidades atemporais: entre a cópia e a queda
}

\author{
I. Memória e lugar
}

O efeito das condições de organização do espaço sobre a percepção do tempo e a sedimentação da memória é problema dos mais relevantes no âmbito das representações poéticas da urbe. Se, de um lado, após Baudelaire, tornou-se lugar-comum evocar os efeitos do descompasso entre a memória e o arrimo que lhe oferecem, ou sonegam, as pedras da cidade (“la forme d'une ville/ change plus vite, hélas! que le coeur d'un mortel”), de outro, os processos de recuperação/museificação do patrimônio urbano e congelamento do passado em cidades cenográficas ou parques temáticos (onde se conserva - e vende - a identidade de certos grupos ou práticas culturais) nos defrontam com fenômenos relativamente recentes, aos quais a poesia talvez não seja alheia.

Ecléa Bosi (1979), em pioneiro estudo sobre a memória de velhos, trata da importância dos apoios citadinos para a produção de lembranças. Explica a autora:

Nós nos adaptamos longamente ao nosso meio, é preciso que algo dele permaneça para que reconheçamos nosso esforço e sejamos recompensados com a estabilidade e o equilíbrio. A vida do grupo se liga estreitamente à morfologia da cidade: essa ligação se desarticula quando a expansão industrial causa um grau intolerável de desenraizamento. (Bosi, 1979, p. 366)

Assim, nossa própria posição no mundo (a relação com o ambiente natural, as outras pessoas, o próprio trabalho) depende desses arrimos que "as mudanças abalam, mas persistem em nós como uma carência” (Bosi, 1979, p. 370), e que só podem ser defendidos ou reconquistados por um esforço coletivo de resistência (de grupos, associações) e pela "rebeldia da memória", que, às vezes, em circunstâncias favoráveis, logra refazer esses antigos arranjos.

Nos capítulos anteriores, referimo-nos à noção de "não lugares", de Marc Augé, como produtos da supermodernidade, locais de trânsito e consumo (formas triunfantes) ou espaços vazios (formas nuas), que se opõem aos lugares antropológicos, por seu caráter 
dessocializante e refratário à sedimentação de memórias ou traços identitários daqueles que os ocupam.

Ocorre que, no campo do planejamento urbano, que se arroga muita vez a missão de redimir as cidades pela defesa de seus traços singulares, essa noção parece legitimar a interpretação simbólica dos problemas sociais, reduzindo-os a sua dimensão cultural.

Crítico severo dos serviços que a etnologia vem desempenhando no processo de espetacularização das cidades, Henri-Pierre Jeudy (2005) demonstra como o marketing urbano, em seu discurso requalificador e preservacionista, emprega noções como as de "rito", "tribo" e "não lugar" para justificar suas práticas. Assim, os etnólogos acabam por se encarregar da criação de ritos, tratados como um "produto cultural cujo uso tem por finalidade a restituição de um poderio simbólico que estaria em falta.” (Jeudy, 2005, p. 36)

Tal atuação corresponderia, de resto, a certo recuo epistemológico da etnologia e à estranha adoção de uma perspectiva pragmática em relação à ordem simbólica, menos objeto de estudo que bem a ser protegido contra os riscos da supermodernidade. Assim, o não lugar, que "devia designar o território sem nome, sem identidade”, torna-se "o brasão por excelência do desenvolvimento cultural” (Jeudy, 2005, p. 122), foco de investimentos para reativação cultural.

Talvez valha a pena remontar essa discussão ao desenvolvimento das "teorias do lugar" (ou contextualistas) no pensamento urbanístico desenvolvido a partir dos anos 1960. Em oposição às "teorias do plano" da arquitetura moderna, de caráter abstrato e totalizante, fundadas em princípios como os da funcionalidade, da estandardização e da tábula rasa, as “teorias do lugar” vão investir na ideia do lugar não somente como entorno físico de implantação das construções, mas como polo imantado de significações coletivas (psicológicas, históricas, antropológicas etc.), cuja carga semântica tem de ser considerada na atividade projetual.

Otília Beatriz Fiori Arantes (2000, p. 123 e seguintes) apresenta em detalhe as contradições teóricas em jogo nessas "teorias do lugar" (as diferenças em relação à voga estruturalista, avessa aos resíduos mítico-metafísicos por trás dos esforços de ressemantização da cidade, e as incoerências na apropriação da ideia heideggeriana de um habitar originário e poético). De todo modo, em chave monumental ou de valorização da arquitetura vernacular/comunitária, a obsessão pela forma-lugar, que surgiu como estratégia 
de resistência contra os traumas da modernização, terminou por revelar sua faceta ideológica, servindo de "reforço da fragmentação da vida urbana e de sublimação da ausência de vida pública numa política de vizinhança”. Cumpriram tal papel ideológico tanto os defensores da cidade-lugar como os arautos da cidade-simulacro, onde a comunicação conta mais que o espaço. Entre essas propostas aparentemente antagônicas, haveria antes convergência, pois ambas parecem caminhar para a indiferenciação entre os espaços externo e doméstico, "igualmente sujeitos à temporalidade da circulação das imagens, ou seja, homogeneizados pelo mundo do marketing." (Fiori Arantes, 2001, p. 162-3).

Abstemo-nos de acompanhar detidamente as vicissitudes desse processo de culturalização da cidade ou de sua transição para um urbanismo anárquico, legitimador da desordem urbana sob o disfarce do culto ao heterogêneo (que abafa conflitos sociais, entronizando a precariedade e a miséria). Em vez disso, cumpre indagar como tal processo afeta a percepção do tempo da cidade e a configuração da memória de seus habitantes.

Nesse sentido, mais do que assinalar quanto a ideologia do espaço público se nutre desse enfoque culturalista, é preciso verificar como ele contribui para as práticas de patrimonialização das cidades, consideradas como espelho de culturas singulares cuja transmissão para a posteridade impõe um "dever de memória" e, portanto, tem de ser controlada pela seleção de que segmentos do passado demandarão de nós um esforço de atualização (Jeudy, 2005).

Reconhecendo como a reflexividade patrimonial opera nos mais diferentes registros - da conservação da memória operária em antigos bairros industriais (conveniente para o patronato, que glamoriza a vida operária e apresenta a exploração como coisa do passado) aos monumentos para vítimas de catástrofes (Hiroshima, Chernobyl, a destruição do World Trade Center etc.), passando por violências étnicas (em que a ajuda humanitária é, às vezes, uma espécie de interregno entre o genocídio e o museu) e intervenções artísticas com moradores de rua (tratados como o "primitivo" dos tempos modernos) -, Jeudy revela como o gerenciamento do passado, em todos esses casos, parece operar mais em favor do recalque que da memória.

$\mathrm{O}$ "dever de memória" pressuposto pela lógica patrimonial suprime a liberdade de esquecer, teatraliza vestígios e cria simulacros que anulam as distinções entre passado, 
presente e futuro. Pretende-se, dessa maneira, eliminar qualquer margem de acaso ou acidente na transmissão. No entanto, esse controle sobre o destino funda-se no engodo da supressão do inatual e, em verdade, contraria o trabalho arqueológico da memória:

O espírito patrimonial oculta, pela imposição de uma conduta retrospectiva, o trabalho arqueológico da memória, essa reconstrução incerta do que foi, e supõe uma destruição parcial do que nos foi dado. [...] É curioso constatar o quanto a própria memória se sustenta com a oposição entre o patrimonial e o arqueológico. A atitude arqueológica da memória provém de uma aventura, e não de uma vontade de se precaver contra as ameaças de um desaparecimento que, ao contrário, continua sendo a origem de sua estimulação. (Jeudy, 2005, p. 27)

Se a memória depende do esquecimento, de uma "destruição parcial do que nos foi dado”, as práticas de restauração (cenarização, museificação) urbana promovem uma destruição de outro tipo, ao engendrar uma unidade fictícia da cidade. Ao eternizar elementos de diferentes épocas, tais práticas impedem a confusão temporal própria das imagens do sonho e da memória que, ainda segundo Jeudy, teriam um tipo de emergência, sobreposição e circulação contrário à estabilidade perceptiva das representações patrimoniais, antioníricas e contramnêmicas.

Referindo-se em outra passagem a monumentos do artista Jochen Gerz ("Monumento contra o fascismo", "Monumento invisível de Sarrebruck"), Jeudy destaca a ruptura em relação ao paradigma da arte comemorativa pela criação de obras que se inscrevem em um tempo precário, com partes veladas/enterradas, em um jogo de aparição e desaparecimento. Tal ruptura seria assegurada por esses "efeitos de vazio" que terminam estimulando a anamnese. "Assim, as falhas da memória - o esquecimento, o buraco, o vazio, a confusão... - são utilizadas para reativar a atividade mnésica, para impedi-la de se comprazer com o ritmo de uma rememoração que teria perdido toda finalidade". (Jeudy, 2006, p. 17)

Contra a repetição farsesca do passado, que elimina hiatos e descontinuidades para esconjurar a ameaça do esquecimento e compensar o déficit simbólico em que vivemos, o jogo da memória, parceiro do sonho e da imaginação, parece se apoiar justamente naqueles hiatos e descontinuidades, bem como nas incongruências perceptivas eliminadas da 
representação patrimonial. Dito de outra maneira: a organização patrimonial determina o sentido das imagens mnésicas, ou seja, aprisiona-as dentro de um arcabouço prévio ao se converter em princípio teleológico, fundamento ético do tratamento espetacular das memórias coletivas.

Tudo isso falando em termos muito genéricos, já que, apesar da globalização das práticas de museificação urbana, não é possível equiparar o peso dessas práticas em diferentes contextos sócio-históricos. No Brasil, essa tendência - que se realiza de modo ostensivo em projetos como o da recuperação do Pelourinho, na Bahia, no parque temático das cidades históricas mineiras ou mesmo em iniciativas como o Memorial da Resistência, nas instalações do antigo Departamento Estadual de Ordem Política e Social (Deops), na cidade de São Paulo ${ }^{101}$ - convive com outros tantos exemplos de abandono, indiferença ou franca hostilidade em relação ao passado e ao patrimônio urbano e ambiental, sobretudo em tempos de neodesenvolvimentismo a qualquer preço.

Sem embargo, apesar das inúmeras distinções que seria preciso fazer no tocante à implantação da lógica patrimonial em diferentes contextos, esses descompassos entre as representações patrimoniais do passado e as elaborações da memória individual não passam ao largo da poesia contemporânea, conforme pretendemos evidenciar mediante a análise de alguns poemas de Paulo Ferraz, com destaque para seus dois últimos livros, Evidências pedestres e De novo nada, ambos de 2007.

\section{A queda e o calendário: o tempo na poesia de Paulo Ferraz}

A reflexão sobre o aspecto temporal no vínculo com a cidade acompanha a poesia de Paulo Ferraz desde seu primeiro livro, Constatação do óbvio (1999). Nessa obra de estreia, em que é bastante acentuada a mistura de temas e dicções (poemas amorosos, metalinguísticos, construções de sintaxe retorcida, cheias de interpolações e andamento argumentativo, descrições à moda cabralina, como o poema "Não faz falta", e textos de inclinação metafísica e tom sentencioso, como a seção "Chuva de esporos”, tributo ao

\footnotetext{
${ }^{101}$ Inaugurado inicialmente com o nome Memorial da Liberdade, em 2002, o projeto sofreu fortes críticas, sobretudo por causa da descaracterização das antigas celas, de cujas paredes as inscrições foram apagadas nos anos 1980, quando o prédio abrigou a Delegacia do Consumidor, e da associação indevida entre tortura e liberdade, contestada por ex-prisioneiros. As críticas levaram à revisão do projeto e à reinauguração do museu, em janeiro de 2009, com o nome Memorial da Resistência.
} 
conterrâneo Manoel de Barros), destacam-se poemas de observação da cidade, como "Num ônibus indo para", comentado no terceiro capítulo três, "No w here", "Rés do chão" e toda a segunda seção, intitulada "Ensaio fotográfico".

Em "Rés do chão", desponta o tema das mútuas inscrições entre corpo e cidade (questão central na obra do poeta gravador Alberto Martins, conforme vimos) em chave erótica. A cidade se imprime no corpo e recebe a impressão dos caminhantes, pois moldam-se cicatrizes, sinal do "coito ingênuo/ de pó e poros" (p. 26). Nesse poema, a temporalidade urbana é mediada pelo intercâmbio entre sola e asfalto, um tipo de corpografia (o poema é todo vazado em versos curtos, trissílabos, mimetizando o ritmo acelerado da caminhada-cópula), que, no entanto, é dissimulada pelos "artifícios do que é novo": recapeamento, recauchutagem.

"Rés do chão" é o penúltimo antes da seção "Ensaio fotográfico", suíte de textos curtos, à maneira de instantâneos, conforme indica o título, produzidos em um mesmo cenário: uma praça pública com pombos, passantes e mendigos. Tais elementos permitiriam a inclusão desses textos no capítulo em que tratamos do desabrigo, mas o problema da temporalidade também se coloca aqui, desde a epígrafe, tomada de Santo Agostinho: “Assim, com as palavras nada mais fazemos do que chamar a atenção; entretanto, a memória, a que as palavras aderem, em as agitando, faz com que venham à mente as próprias coisas, das quais as palavras são sinais." (Santo Agostinho, 1980, p. 291-2). O trânsito das palavras às coisas, isto é, a consumação da operação simbólica, é facultado pela memória, que lastreia os sinais. Porém de que maneira se efetiva, se é que o faz, o potencial mnêmico nas imagens citadinas que compõem o "ensaio"?

A suíte é composta de sete segmentos em que se alternam uma voz em primeira pessoa (segmentos 1 e 5) e outra em terceira (demais segmentos). Opõem-se, ao longo das cenas, o ponto de vista dessa primeira pessoa, o passante apressado ("destenho paciência, por isso como às/ pressas as horas num café”, p. 31), e as descrições da praça com pombos e mendigos. Se em "Rés do chão" a memória era como que apagada por artifícios de renovação, que deliam as cicatrizes do coito entre sola e asfalto, nesses poemas, de modo diverso mas com o mesmo efeito, a percepção do tempo no espaço público é cancelada pela fusão entre o homeless e a praça: 
chegam ao mimetismo o mendigo e o chão da praça sem sombra sequer de memória, os pombos constroem ninhos em sua cabeça.

Tal identificação parece integrar completamente o mendigo a seu entorno, naturalizando/ocultando a miséria (invisível mesmo para os pombos), inofensiva como as estátuas.

Pausa para digressão. Em seus mais recentes trabalhos, a arquiteta Paola Berenstein Jacques $(2006,2010)$ vem postulando a ideia de um "urbanismo errante" como estratégia de resistência à espetacularização da cidade. Ela se serve de ideias de Certeau sobre o espaço como "lugar praticado" (por uma experiência corporal, tátil, cinestésica das ruas) e insere a errância dentro de um continuum histórico que vai da flânerie oitocentista aos jogos psicogeográficos e derivas situacionistas dos anos 1950-1960, passando pelas deambulações surrealistas em busca do acaso objetivo. Com base nesses antecedentes, Jacques especula sobre as condições de possibilidade da errância contemporânea, guiada pelos princípios de desorientação, lentidão e corporeidade/incorporação. Para a leitura dos poemas de Ferraz, interessa-nos especialmente a ideia da lentidão, que não se refere ao grau de desaceleração do movimento, mas a uma disposição subjetiva, "uma outra forma de apreensão e percepção do espaço urbano, que vai bem além da representação meramente visual" e que pode até mesmo se dar "por meios rápidos de circulação" (Jacques, 2006, p. 123).

Jacques apoia-se em Deleuze e Guattari para pensar a diferença entre "lento" e "rápido" não em termos de velocidade, mas de qualidade do movimento, e também no geógrafo Milton Santos, que vincula lentidão e pobreza. A autora lembra que, de acordo com Santos, os pobres constituiriam bom exemplo da categoria "homens lentos". Pela mobilidade reduzida e por serem obrigados a deslocamentos demorados (dada a maior distância entre suas residências e os locais em que há oferta de trabalhos e serviços), pela própria falta de acesso ao transporte público ou por viverem no desabrigo, enxotados de lá para cá, eles se relacionariam com a cidade de modo mais profundo e visceral, mesmo que involuntariamente ou à revelia.

Conquanto o foco de Jacques recaia sobre o errante intencional, voluntário, crítico, aquele cuja lentidão não depende de classe, etnia ou sexo, é de se indagar quanto não há de 
idealização na ideia de que os pobres, homens lentos involuntários, têm uma experiência urbana mais profunda, considerando que a precariedade que os obriga a um contato mais intenso com a rua também magnifica as "defesas" contra os riscos dessa exposição, isto é, suscita certa insensibilidade adaptativa.

Encerramos esse pequeno desvio para voltar ao mendigo de Ferraz, cuja lentidão se transforma em paralisia. Diante dele, vai-se a memória dos pombos (segmento 2) e também a das pessoas, que "largam lembranças por demais ao léu" (p. 35), "cacarecos" recolhidos pela personagem da voz em primeira pessoa, que perdeu a pressa que tinha. Além disso, a petrificação dos homeless é compensada pela operosidade dos pombos mais ligeiros, que "fingem ser cães", engolem os cacarecos-lembranças (que a primeira personagem coleciona) e até mesmo revelam a humanidade dos "filhotes de homem", os quais, "fluentes em lixo", "camuflam-se de fuligem"102, mas se tornam visíveis pelo "reflexo do ruflar/ das asas dos pombos em sua retina".

Vale notar que, a despeito do contraponto entre primeira e terceira pessoas, entre mendigos inertes e pombos em metamorfose, alguns trejeitos de linguagem parecem cancelar a carga social da miséria pelo recurso a algo que lembra um pouco a "retórica do nada" e a "mística do inutensílio" de um Manoel de Barros, interlocutor forte na seção final do livro ${ }^{103}$. Nota-se isso no neologismo com que a suíte começa "destenho paciência", e em expressões como "inata propensão para o nada", "aformosear o alinho", "filhotes de homem fluentes em lixo" etc.

De toda maneira, a impressão de suspensão temporal pela fusão do mendigo à paisagem (acentuada talvez por isso que chamei de certo niilismo retórico) é quebrada pelo elemento trágico que Ferraz introduz no segmento final: um acidente que crispa água parada do presente com um aceno de futuro, ainda que infausto:

um instante antes, dera um passo

de homem, agora não passa de uma pasta

\footnotetext{
${ }^{102}$ Ainda com relação à ideia de camuflagem ou mimetismo/fusão à paisagem como fenômeno de "invisibilização" dos párias urbanos, lembro depoimento do poeta referindo-se aos moradores de rua como "camaleões": "Eu morava no centro, na avenida São João, defronte ao Minhocão, ou seja, tinha uma relação com a cidade bastante agressiva. Estar ali, ao lado do Minhocão era estar próximo do maior atentado contra a cidade, entre tantos que há. Mas o Minhocão era para mim uma violência. Ali me lembro de ter visto uma senhora chegando na rua. Era uma senhora digna, com sua mala, comportada, com medo. Você via que ela tinha medo. Pouco a pouco, ao longo das semanas, eu fui vendo aquela senhora ir perdendo a dignidade e, como um camaleão mesmo, ir se adequando àquela nova realidade da rua. Uma realidade onde não há banheiros, não há quartos, em que tudo se faz às claras. Pelos cantos, mas às claras. É um impacto". (Ferraz, 2012).

${ }^{103}$ Em verdade, depois dela há ainda um postscriptum, o poema "Puerpério".
} 
impressa no asfalto. a curiosidade anda em círculos

por terra e céu como fome de vísceras. junto ao

cadáver, um pombo

interpreta no exposto o agouro de seu ocaso.

Não se sabe exatamente a que sujeito se refere a frase "dera um passo de homem". Seria um mendigo, a personagem da voz em primeira pessoa ou mesmo outro pombo a usurpar a humanidade perdida por seus companheiros de praça? As aves que antes se fingiam de cães bem podiam dar agora um passo mais ousado, "passo de homem", hipótese que parece apoiada pela menção à pasta resultante do acidente ${ }^{104}$. O que importa, porém, é reter o papel desempenhado pela catástrofe na relação com o tempo, na expectação do futuro sob a forma do agouro, elementos que vão reaparecer, sob outro arranjo, nos livros posteriores de Ferraz, em que a reflexão sobre a temporalidade ressurgirá de modo mais complexo.

No livro Evidências pedestres (2007), a reflexão sobre o tempo desloca-se do âmbito da sociabilidade nos espaços públicos para a própria arquitetura, como se vê no poema "Canteiro" (p. 18):

\section{CANTEIRO}

Bicho ao inverso, cresce primeiro o esqueleto descarnado - a pele lhe é posta por último, quando o corpo atinge $o$ tamanho almejado. Triste vê-lo assim: de pé no útero-tapume (feto concebido in papyru), formando-se de ferro e vidro, que o deixarão para sempre autista, para ter em si criaturas, frágeis, parasitas que ignoram onde pisam, comem, fodem, cuidam

\footnotetext{
${ }^{104}$ A mesma imagem da pomba esmagada como espelho em que o poeta se mira a contemplar o destino que lhe reserva a metrópole aparece no poema "Deformação" de Donizete Galvão: "aí está você:/ uma chapa/ uma pasta/ de pena e sangue/.../ eh pomba lerda/ viu o que a cidade lhe fez?/ Bem feito para você./ Viu o que a cidade nos fez?". (Galvão, 2003, p. 74).
} 
de seus filhos, bichos, plantas.

Suas sapatas

nunca irão sambar.

Aqui é o tempo biológico que se encarna no edifício, cuja construção é comparada à gestação de um organismo vivo. Tal expediente se coaduna com a vertente de erotização do urbano, explorada na discussão dos poemas de Pádua Fernandes e também presente nos poemas de Ferraz (por exemplo, na imagem da caminhada como coito entre sola e asfalto).

A imagem gestacional usada em chave metalinguística já comparecia em "Puerpério", poema final de Constatação do óbvio, em que a persona poética se refere aos escritos como algo longamente concebido e temido por sua possível monstruosidade; algo que se deseja descartar no lixo, crime diante do qual se requer, mais que perdão, brandura da pena.

De modo semelhante, mas em sentido inverso (o ser amado comparado a uma obra de engenharia gestada pelo amante), também se pode ler a segunda seção do poema "Sweet suíte”, de Meu sol, minha primavera: “... engenheiro/ de obra pronta imagino a/ técnica a arte de te/ modelar, por exemplo,/ dentro de minha boca/ nasceriam cada dedo,// seus mamilos, do giro/ de meus lábios sobre seus peitos [...]” (p. 8).

Entretanto, no que concerne a "Canteiro", não devemos nos esquecer de que as imagens corporais para qualificar o crescimento do edifício não são criação exclusiva do poeta, apoiando-se também em metáforas já presentes no próprio vocabulário arquitetônico, como o termo "pele" para designar a superfície envoltória de uma construção. A esse respeito vale notar, aliás, a importância dada ao material empregado como pele para edifícios na obra de arquitetos "desconstrutivistas", como Frank Gehry. A insistência no uso de materiais expressivos, que intensifiquem a experiência cognitiva do observador/usuário, foi mais um meio, entre outros, de superar o binômio moderno formafunção, apostando na visibilidade como valor autônomo. ${ }^{105}$

Servindo-se então dessa metáfora prévia, Ferraz cria outras derivadas, entre elas a expressão "útero-tapume", bem como o deslizamento do (feto concebido) "in vitro" para

\footnotetext{
${ }^{105}$ Conforme comentário de Fábio Valentim à casa do arquiteto em Santa Monica, EUA (Valentim, 2008, p. 17).
} 
"in papyro" e a designação dos moradores como parasitas, seguindo o modelo das interações biológicas, ecológicas.

O poema adota, de modo não ortodoxo ${ }^{106}$, o padrão da redondilha menor, com uso ocasional de rimas toantes (pele/cresce, parasitas/pisam), aliterações e assonâncias, mas sua maior aposta é mesmo nas imagens, sobretudo a da dessincronia entre pele e esqueleto, da qual ele faz derivar o autismo do edifício e de seus habitantes-parasitas, que "ignoram onde pisam,/ comem, fodem, cuidam/ de seus filhos, bichos,/ plantas".

Por fim, explorando o potencial metafórico de outro termo técnico, "sapata", que em engenharia designa a fundação direta para pilares ou paredes, a figura do corpo aparece uma última vez pela referência à dança, ao samba como antídoto inalcançável contra a má-formação do feto-edifício, seu autismo congênito, que se transmite aos parasitas que o habitam. O fecho é preparado de maneira habilidosa pelo desmembramento do penúltimo verso, que, para seguir o padrão da redondilha, deveria ser "plantas. Suas sapatas", com ditongação do pronome possessivo. Trata-se de um efeito curioso, não apenas por amplificar o sentido da primeira palavra isolada ("plantas": dos moradores? dos edifícios, as que orientam o trabalho no canteiro de obras?), mas também por quebrar o pé do verso, obrigando-o a dar a "sambadinha” que o edifício jamais dará.

Por fim, há também a ironia com a própria ideia da falta de samba, que, objetivamente, seria algo a festejar (a solidez do prédio a salvo de tremores e desmoronamentos), mas que, nesse contexto de autismo e vida parasitária, parece ser lamentada pelo que traria de "compensação" à tristeza ("Triste vê-lo assim") que atravessa o poema.

Embora aqui o problema da temporalidade urbana pareça obliquamente colocado, por causa do viés biomórfico (concepção e crescimento), ele está presente como recalque da dimensão do trabalho que nos conduz do papyru ao canteiro de obras. Esse tempo naturalizado de um feto que cresce por si revela-se bastante apropriado aos diversos signos de ocultamento presentes no poema: o tapume, a pele de vidro que esconde o esqueleto e, por fim, o autismo dos moradores (metonimicamente atribuído ao prédio), apartados da cidade e condenados ao parasitismo.

${ }^{106}$ Com sinalefas ousadas (bi/choaoin/ver/so/cres), elisão de sílabas após a última tônica e o curioso desmembramento do penúltimo verso, comentado a seguir. 
Situação muito diversa pode ser encontrada no poema "Vagas para rapazes", do mesmo livro (p. 10).

\section{VAGAS PARA RAPAZES - AMBIENTE FAMILIAR}
A planta o pai trouxe in- teira na cabeça - do piso à cumeeira, sem esquecer os detalhes e cor - de Paris. O pai queria ser dono de um palácio. Quando nasci, já havia mais de dezenas de cópias nos Campos Elíseos, e mesmo na Barra Funda. Depois vieram
os prédios, o asfalto, os carros e o pai se foi. Logo, vendemos o mármore, os móveis e um quê de vaidade. A mãe relutou uns tempos...
Ah, sim, são duzentos reais o mês num quarto pra quatro, banheiro: o do corredor, mas - a- viso - corto a força a- pós cinco minutos.
(Hoje alugo vagas, a planta ainda é a mesma que o pai trouxe, as cópias nos Campos Elíseos e na Barra Funda não estão mais de pé.)

Em um primeiro nível, o poema poderia ser lido quase como uma crônica sobre o apogeu e a decadência da região central de São Paulo. De algum ponto próximo aos Campos Elíseos e à Barra Funda, uma voz recorda o passado oitocentista da cidade e de 
seus bairros nobres onde residia a aristocracia do café, em elegantes mansões cujo desenho era decalcado de modelos europeus. Uma voz narradora remonta a esse tempo faustoso, ao qual se seguem a morte do pai de família, construtor do imóvel, e a transformação deste em cortiço com quartos para aluguel.

No que concerne à organização formal, temos cinco estrofes com versos brancos em redondilha menor. Nas três primeiras, vê-se o histórico do imóvel e da família proprietária narrado por um de seus descendentes, que se identifica pelo uso da primeira pessoa somente a partir da segunda estrofe.

A construção do imóvel fora motivada por um desejo de distinção ("queria ser dono de um palácio") contrariado, porém, em primeiro lugar, pelo servilismo de estilo (a planta trazida "na cabeça", feita de improviso, não passava de uma cópia), depois, pela multiplicação de cópias semelhantes e, afinal, pela modernização acompanhada do empobrecimento da família.

$\mathrm{Na}$ quarta estrofe, uma surpresa dá mais vivacidade ao relato: percebe-se que a situação de penúria, iniciada há tempos, quando a cidade começava a se verticalizar e a se motorizar, estende-se até o presente, pois tudo o que fora dito não passava de um preâmbulo para apresentar as condições de aluguel. A voz locadora, até então solitária, dirige-se a um interlocutor com quem negocia. A pindaíba então se revela de modo completo: as vagas são em quarto coletivo, o banheiro é externo e a energia, racionada.

$\mathrm{Na}$ estrofe final, encerrada entre parênteses (revelando talvez o endereçamento a um interlocutor distinto do potencial inquilino ou um aparte em tom de confidência), a observação sobre o fato de que o imóvel, "cópia pioneira", resistiu às demais cópias que vieram depois dele - o que parece ser dito com um misto de vaidade e melancolia, fruto do pressentimento de que a demolição também o aguarda em um futuro próximo.

Esse é outro poema que poderia ter entrado no capítulo em que tratamos das representações do desabrigo e da moradia precária. Preferimos, contudo, comentá-lo aqui, junto de outros poemas em que abordamos o tempo nas representações da cidade, principalmente por tratar do estatuto extemporâneo da cópia, ou do vínculo entre repetição e decadência, espécie de ideia fixa na poesia de Paulo Ferraz. Em Evidências pedestres essa ideia fixa aparece com maior clareza principalmente nos poemas sobre intervenções artísticas, como “Tragédia urbana” (p. 9). 


\section{TRAGÉDIA URBANA}

A maquete fora elogiadíssima na Bienal de Veneza,

- Meu objetivo é representar a suspensão do tempo, o fim da história, como se usa dizer. Por isso, serão utilizados materiais reciclados, comprados em demolições, ou fabricados por artesãos especializados em imitações: na fachada haverá frisos compostos de entulhos de velhos Ramos de Azevedo; os balanços serão de casas neocoloniais; no lobby serão erguidas paredes de adobe; haverá ferrarias da Sorocabana Railway; as portas, janelas e maçanetas virão de cidades históricas de Minas. Haverá, mas escondido, um pedaço de Niemeyer, um pequeno enigma para meus pares. Não, nada aqui será anacrônico, pois o presente e o passado estão os dois no futuro, não é assim que disse aquele poeta inglês? Pound, não é? Seja quem for, é o futuro sendo extraído das ruínas do tempo.

tanto que resolveram construí-la - marco

aistórico - após um grande estudo

sociológico,

na zona cerealista da cidade.

Ninguém notou que era um marco,

até que um pivete

resolveu pichar o nome da namorada

numa das torres.

Quem hoje passa lá

ainda lê o nome pela

metade e ainda

vê o corpo caindo.

O poema se abre em registro irônico. Depois de referir a legitimação do projeto no circuito internacional das artes, pela menção à prestigiada Bienal de Veneza, irrompe no corpo do poema uma fala em prosa, destacada do restante do texto pelo uso de itálico e do recuo à esquerda: o depoimento do arquiteto responsável pelo projeto. Tal depoimento revela o intuito de alcançar uma intemporalidade programática pelo pastiche de vários estilos e materiais: do colonial ao moderno; das paredes de adobe ao enigmático "pedaço de Niemeyer", passando por Ramos de Azevedo e pelo ferro da estrada Sorocabana. Tudo 
entra e se equivale, em uma coleção de vestígios de todos os tempos (autênticos ou replicados) na qual, paradoxalmente, "nada é anacrônico", o passado e o presente reunindose no futuro, extraído das ruínas.

A arte como cópia/colagem/reciclagem de estilos pretéritos; o novo como repetição; a tradição como conjunto inerte e disponível para consumo em infinitas (e arbitrárias) possibilidades combinatórias; a arte como jogo de adivinhação entre pares, desafiados por "pequenos enigmas" e empenhados tão somente em decifrar o puzzle de citações, descobrindo o que veio de cada lugar; o projeto como "quimera" (não no sentido utópico ou visionário, mas no de combinação de elementos incongruentes) arquitetônica, enfim, tudo aparece de maneira condensada nessa fala caricata.

Não seria o caso de recuperar aqui as formulações do pós-modernismo na arquitetura (o sincretismo total contraposto ao purismo geométrico, à racionalidade construtiva das vanguardas dos anos 1920; a defesa de um ecletismo tolerante; as críticas ao funcionalismo formal com ênfase no papel simbólico da forma e valorização da fachada e dos elementos decorativos, a ideia de que "a forma segue o fiasco") tal como expostas nas obras de Robert Venturi, Charles Moore e Peter Blake. Aproveitando o fato de que a justificativa para a instalação é feita via literatura - pela atribuição errônea do célebre verso de T. S. Eliot ("Time present and time past/ Are both perhaps present in time future", o começo dos Four Quartets) ao poeta (estadunidense, não inglês) Ezra Pound -, talvez seja oportuno, para os fins de nossa investigação, pensar literariamente nesse paradoxo de uma atemporalidade contemporânea tendo em vista o contexto da poesia brasileira após a dissolução do antagonismo entre concretos e marginais.

Segunda digressão. Em seu célebre texto "Poesia e modernidade: da morte da arte à constelação do poema pós-utópico”, publicado originalmente em 1984, Haroldo de Campos refere-se à "pluralização das poéticas possíveis" como superação do "projeto totalizador da vanguarda" e da "utopia redentora" que lhe servia de apoio. A poesia brasileira tornava-se, a partir daquele momento, uma poesia da presentidade, da agoridade, não mais refém do "interpretante final" do "porvir messiânico", que estancava "a 'semiose infinita' dos processos sígnicos”. Não obstante, ela conservaria a dimensão crítica da utopia e, portanto, não deveria "ensejar uma poética da abdicação" nem "servir de álibi ao ecletismo regressivo ou à facilidade" (Campos, 1997, p. 268-9). 
O texto de Haroldo de Campos constitui uma espécie de marco na história recente da poesia brasileira, principalmente por servir de justificação teórica ao discurso da diversidade, da convivência pacífica entre projetos distintos, uma vez superados os antagonismos ideológicos por meio dos quais a noção de novo se definiu no passado, e que teriam desaparecido com o fim das vanguardas. ${ }^{107}$ Referindo-se a esse "paradigma da diversidade", assimilado sem contestação por boa parte da crítica e dos próprios poetas, Simon (2012) identifica nele uma atitude de esquiva em relação à tarefa de nomear as forças em conflito no tempo presente. Segundo ela, o argumento haroldiano pouco teria que ver com o tempo-agora (Jetztzeit) de Walter Benjamin, no qual alega inspirar-se. Enquanto no filósofo alemão a agoridade supunha um engajamento no instante (vislumbre/centelha), a fé no potencial revolucionário da interrupção, a agoridade haroldiana seria permansiva, recaindo na homogeneidade e no vazio contra os quais Benjamin se punha. De modo semelhante, enquanto o "agora" da poesia feita no ocaso das vanguardas supunha, para Octavio Paz (outro autor recrutado por Campos), a imediatez física e prazerosa, a rebelião do corpo e da imaginação (sua crítica ao progresso dependia das imagens do desejo e do mito, que dissolvem passado e futuro em um presente sem data), a presentidade haroldiana seria de natureza mais abstrata, desincorporada, reduzindo a potência dialogante do presente à dimensão do intertexto e da tradução.

Ainda conforme Simon, esse "pós-utópico" não advoga oposição às tradições vencidas nem ao cânone, definindo antes a passagem de uma linguagem excludente (a das vanguardas) para uma forma de ecumenismo afim do ethos democrático ${ }^{108}$ da diversidade social e até da ideia de proteção à "biodiversidade". Nesse sentido, a valorização do heterogêneo é feita em termos de acúmulo, preservação, estocagem e gerenciamento das diferenças, e não da noção de cruzamento (mestiçagem, hibridização), por exemplo. Esse estado pluralista assenta-se no pressuposto de um interregno histórico em que nada acontece e conduz a uma espécie de "proliferação estéril”, que escamoteia os conflitos

\footnotetext{
${ }^{107}$ A poesia pós-utópica "não necessita mais, para definir-se de recorrer a uma 'oposição dominante', seja ao passado, seja a si mesma, conforme o requeria o esquema característico do conceito de modernidade em seu processo histórico evolutivo de autoafirmação", explica Haroldo de Campos (1997, p. 269).

${ }^{108}$ Simon apoia-se aqui, como em outros momentos, nas ideias de Hal Foster tal como expostas no ensaio "Contra o pluralismo": “(...) a ideia do pluralismo em arte é em geral misturada à ideia de pluralismo na sociedade. De qualquer modo, ser um advogado do pluralismo é ser democrático - é resistir ao domínio de uma facção qualquer (nação, classe ou estilo). Mas isso não é mais verdadeiro do que sua recíproca: ser um crítico do pluralismo é ser autoritário" (Foster, 1996, p. 53).
} 
subjacentes às dessemelhanças, donde seu caráter conformista, acrítico, a despeito das intenções em contrário.

Antes de encerrar essa digressão e retornar ao poema, cumpre lembrar que os impasses colocados pelo programa pós-utópico à poesia brasileira também constituíram objeto de investigação crítica para o poeta Paulo Ferraz. Em sua dissertação de mestrado, ele se dedicou a examinar a relação da poesia brasileira com o legado moderno após a exaustão da "vanguarda" concretista e da contestação contracultural dos poetas marginais. Ferraz reconhece na produção surgida a partir daí uma "consciência da posteridade", ou melhor, da "posterioridade"109 (em relação aos grandes movimentos artísticos do século $\mathrm{XX})$, julgada de diferentes modos pela crítica ${ }^{110}$, e se opõe ao diagnóstico de anacronismo ou relação pacificada com a tradição. Em vez disso, ele identifica na poesia feita a partir da década de 1980 o que designa pela expressão "estética da dúvida", caracterizada como "uma nova forma de inquietação, que, na ausência de um estilo particular, se apropria da voz alheia, que, nos melhores momentos, não se apresenta nem como adesão irrestrita, nem como imitação barata, mas como diálogo crítico". (Ferraz, 2004, p. 17).

Tal inquietação se expressaria também pelo que Ferraz chama de "filiação de perplexidade", que ele encontra na obra de Régis Bonvicino e Carlito Azevedo, respectivamente em poemas como "Vida paixão e praga de rb", de Sósia da cópia (1983), e "A uma passante pós-baudelairiana", de Collapsus linguae (1991). Em Bonvicino, Ferraz destaca a estratégia de depreciação do eu poético, confundido com o eu empírico, por meio de uma apropriação crítica da taxonomia poundiana (inventor, mestre, diluidor...) empregada pelos concretos. Régis se apresenta como diluidor, epígono, menino de recados, enfim como um cultor da cópia que, no entanto, se serve de ferramentas da poesia concreta para contrariá-la (e a seus tabus ${ }^{111}$ ). Ferraz contrapõe-se assim à leitura de Dantas (1986), para quem Bonvicino tentava conciliar de modo precário a experiência urbana exasperada e

\footnotetext{
${ }^{109}$ Por ocasião da defesa do mestrado de Ferraz, Iumna Simon, que foi uma das arguidoras, observou que a expressão "consciência da posteridade", tomada de empréstimo a Italo Moriconi, é imprecisa, pois pode se referir à consciência do futuro, isto é, à consciência que os grandes autores do século XX tinham em relação ao seu desejo de permanecer, de fazer escola, deixar uma descendência. Ferraz emprega o termo em sentido oposto, ou seja, refere-se à consciência que os poetas contemporâneos têm de seu vínculo (que pode ser sentido como dívida ou direito de herança) com o passado. A fim de desfazer a confusão entre as duas acepções, Simon propunha que se designasse o fenômeno descrito por Ferraz como consciência de "ser posterior" ou da "posterioridade", sugestão que adotamos aqui.

110 “A essa relação com o passado tem-se chamado epigonia e anacronismo, dos quais derivam juízos variados, desde 'normalização', 'retradicionalização', passando por 'conservadorismo', até 'superação'. Positiva ou negativamente, hoje o passado não é um antagonista, mas um coadjuvante importante que tanto fornece modelos e dicções quanto problemas suspensos a serem solucionados no presente e para o presente." (Ferraz, 2004, p. 16)

${ }^{111}$ Com base na correspondência entre Leminski e Bonvicino, Ferraz dá muita importância ao lado mais manifesto desses tabus, subestimando talvez a incorporação inconsciente de certos procedimentos que impedem ou limitam a mediação subjetiva da matéria a que os poemas se abrem.
} 
o purismo, a idealização formal do concretismo. Para Ferraz, ao contrário, não haveria da parte de Régis desejo de conciliação, mas antes exploração dos conflitos entre essas duas dimensões.

Já em relação ao poema de Carlito, Ferraz destaca o uso irônico de uma retórica kitsch (Ferraz, 2004, p. 187) que se apropria de clichês literários do passado ${ }^{112}$ em tensão com um "rastilho de contemporaneidade" ligado à imagem final do "tiroteio""113.

Sem entrar no mérito das análises de Ferraz e em sua eficácia persuasiva, concentremo-nos em sua hipótese de trabalho, qual seja, de que a "consciência da posterioridade" na poesia brasileira contemporânea não implica necessariamente o uso conformado (oportunista ou ingênuo, melancólico ou exultante) do espólio moderno, cuja herança é reivindicada de modo automático, sem sombra de descontinuidade nem esforço de conquista, sem crítica nem emulação, segundo uma lógica de sucessão que reduz o trabalho à competência imitativa ou combinatória, convertendo os pósteros em rentistas zelosos do patrimônio herdado sem testamento. Ferraz prefere ver na obra de alguns poetas um uso controlado do anacronismo, em que a ironia e a autoironia, a distância entre procedimentos formais e matéria urbana, entre a citação e o dado contingente expõem conflitos e inquietudes, oferecendo um testemunho do tempo presente.

Para encerrar essa longa digressão, nossa hipótese aqui é a de que, por meio de poemas como "Tragédia urbana" e o extenso "De novo nada", com que encerraremos este capítulo, Ferraz busca encenar poeticamente os dilemas dessa consciência perplexa da posterioridade e desse uso crítico do anacronismo. Tal encenação, para retomar nossas considerações no início deste capítulo, libera o tempo da armadilha museológica imposta pelo espírito patrimonial e libera a percepção para os trabalhos da arqueologia e do devaneio. Assim, em “Tragédia urbana”, ao tratar da conversão de um marco a-histórico em fonte de memória (memória trágica, mas memória), o poeta não estaria também pondo em

\footnotetext{
${ }^{112}$ De um passado abstrato e internacional, com direito a "danúbios imaginários", "calígrafos orientais", "machadinhas de jade" e "guitarras mouriscas".

${ }_{113}$ “A palavra 'tiroteio', tão cotidiana nos dias de hoje, cujas balas 'passantes' são tão ávidas por pessoas incautas, destoa do conjunto (a despeito de sua função melódica com já mencionada), já que é um rastilho da contemporaneidade que está além dos limites do poema, criando um aparente embate entre esferas, a priori, imiscíveis: o tradicional e o contemporâneo.” (Ferraz, 2004, p. 194)

A análise do poema leva outras coisas em consideração, mas força a nota em relação a esse "rastilho de contemporaneidade", fundamental na configuração da tal "estética da dúvida". O próprio intérprete admite a inexistência de outros elementos contingenciais no poema e reconhece, na contramão de seu argumento, que, as alterações feitas por Carlito ao longo do tempo (de Collapsus linguae à antologia Sublunar, quando o poema passa a se chamar "Nova passante") acentuam a abstração, a literatice do poema: "O que havia de mais concreto foi extirpado do poema: 'entre tantos circunstantes, raptores fugidios'. Esse sim um verso, não pós, mas baudelairiano, talvez por essa razão alterado pelo 'istmo de mim a isto', que retira qualquer referência a um espaço chamado rua, de essencial importância na vida moderna, deslocando-a para além do poeta.” (Ferraz, 2004, p. 204).
} 
questão a perspectiva de uma saída crítica para a poesia contemporânea, paralisada diante da força do legado moderno? Voltemos ao poema.

Conforme notamos, ele começa com a transcrição da fala do arquiteto, que apresenta sua quimera citacional com um quê de pose, rapidamente desmascarada pelo erro na atribuição do verso de Eliot a Pound. A escolha do verso é também feliz, porque, além do erro na indicação da fonte, a frase de um poeta do alto modernismo, usada como justificativa para o pastiche, tem o sentido deformado pela supressão do contexto. No poema de Eliot, o reencontro dos tempos é fruto de uma conquista difícil, frágil e pouco exultória $^{114}$, ao contrário do jogo de esconde-esconde proposto pelo autor da instalação.

Após o trecho de depoimento em primeira pessoa, o poema retoma o relato, em verso livre, na terceira pessoa, sobre o destino da obra. Sua construção na zona cerealista, região central de São Paulo, foco de projetos de gentrificação ${ }^{115}$, conecta o circuito internacional das artes às iniciativas de marketing urbano (o marco que é também marca/grife na vitrine das cidades), levadas a cabo, como notou Jeudy (2005), com o endosso das ciências humanas (no caso do poema, um “estudo sociológico” prévio).

A jogada de marketing, porém, é malsucedida, pois o "marco a-histórico", concebido pela justaposição arbitrária de estilos e implantado de modo igualmente arbitrário em um sítio estratégico, contraria as expectativas: torna-se invisível, não é notado por ninguém, conforme se lê na segunda estrofe.

É nesse exato ponto que o poema propõe uma virada surpreendente ao contrapor à ineficiência do marco oficial um outro tipo de marco: a pichação. Opõe-se assim, a arte oficial, monumental, pública, ciosa de reunir e perenizar os tempos em um todo sem fissuras, ao gesto criminoso ${ }^{116}$, motivado por razões individuais e afetivas (a exibição do nome da namorada), e efêmero pela própria natureza de inscrição, feita sobre suporte delével $^{117}$.

\footnotetext{
${ }^{114}$ Conforme se depreende de versos como "All time is unredeemable"; "Only through time time is conquered", "Here is a place of disaffection", "And all is always now. Words strain,/ Crack and sometimes break, under the burden,/ Under the tension, slip, slide, perish,/ Decay with imprecision, will not stay in place,/ Will not stay still”.

${ }_{115}$ Basta lembrar da longa disputa pela demolição do Edifício São Vito, situado na zona cerealista. O prédio veio abaixo em 2011 e em seu terreno serão construídos um centro gastronômico e um estacionamento subterrâneo (Folha de S.Paulo, 3 maio 2011).

${ }^{116}$ De acordo com a lei federal número 9.605 de 1998, a pichação constitui crime contra o meio ambiente.

${ }^{117}$ Alexandre Barbosa Pereira (2007) destaca o empenho dos pichadores em conservar a memória de seus feitos, distribuindo folhinhas que permitam a identificação de sua assinatura, tirando fotos dos "pichos" e colecionando material de imprensa. Lembra o pesquisador que a efemeridade das assinaturas também se deve à prática do "atropelo", em que grupos rivais encobrem a assinatura uns dos outros com novos "pichos".
} 
A surpresa maior, entretanto, ocorre na terceira estrofe, com a notícia da queda do pichador, que deixa a inscrição pela metade. A estrofe inteira é muito feliz na urdidura, que vale comentar. Primeiramente, à diferença das demais estrofes, em que a única constante parece ser o número de versos (quatro), a estrofe derradeira adota a redondilha (maior nos dois primeiros versos, menor nos dois últimos) como padrão métrico. Além disso, destacase o uso de rimas toantes emparelhadas (por lá/pela; ainda/caindo) e um enjambement performativo, que mimetiza a interrupção do nome ao fracionar a expressão "pela metade". Por fim, mencione-se o rendimento expressivo em deixar apenas para o último verso a notícia do desastre, que explica a razão do nome interrompido e ilumina retrospectivamente o poema inteiro.

Trazido permanentemente à memória pelo nome interrompido, o acidente logra aquilo que o monumento pretendia: unir passado e presente. $\mathrm{O}$ gesto inacabado do pichador funciona, assim, como uma "ruína viva", com o potencial mnésico que faltara à quimera arquitetônica, o que nos reconduz às considerações de Jeudy sobre a diferença entre a reflexividade patrimonial da cidade-museu (totem totalizante, fetiche a esconjurar civicamente os riscos do oblívio) e a arqueologia da memória, que se alimenta da descontinuidade e da incongruência entre diferentes percepções.

A catástrofe do pichador, ponto fulcral do poema, parece relacionar-se com as imagens de queda (cumprida ou imaginada) nos poemas anteriormente comentados: o cadáver em pasta na última parte do "Ensaio fotográfico", o samba-abalo no edifício autista de "Canteiro" e a demolição dos antigos palacetes em "Vagas para rapazes". Curiosamente, a catástrofe (extinção de traços culturais, práticas simbólicas, memória de grupos) é também o contraponto imaginário que legitima os esforços patrimonialistas, demandando uma espécie de paroxismo da coesão social assegurado pela monumentalidade. Sem falar nos casos em que a própria catástrofe se torna objeto patrimonial (nos memoriais a vítimas de guerra, desastres etc.) com a conversão da morte em sacrifício, exploração espetacular do martírio etc.

No poema, contudo, a queda do pichador não tem caráter exemplar, não se erige como símbolo de martírio, não serve de válvula de escape para aliviar culpa nem expressar solidariedade de classe. A instabilidade que produz não tem impacto lírico ou emocional decorrente do uso espetacular das imagens do acidente nem da exploração da biografia da 
vítima, como ocorre em uma canção como "Construção", de Chico Buarque, ou mesmo, mais remotamente, em um poema como "Morte do leiteiro", comentado no primeiro capítulo. $^{118}$

Julgo que o que há de original aqui, à diferença dos exemplos citados, é o uso metalinguístico da queda. Tal uso critica a inocuidade do discurso artístico, em conluio com as forças hegemônicas de produção do espaço urbano, contrapondo aos falsos enigmas (que reduzem a obra a um frívolo jogo de adivinhação entre pares) o verdadeiro enigma da inscrição. Ao representar uma prática que, de saída, subverte a lógica patrimonial (como tentativa de acesso à esfera pública, julgada vandalismo pela maior parte da população), o picho pela metade enlaça corpo e cidade pelo viés trágico e desata o jorro da memória sobre o gesto interrompido.

Se nos capítulos anteriores insistiu-se sobremaneira sobre a fixidez/mobilidade, distância/proximidade, unidade/multiplicidade dos pontos de vista em jogo nas representações da paisagem urbana e de seus párias como critério de mudança (e contemporaneidade) nas representações poéticas da cidade, aqui o interesse principal recai sobre o papel da arte na criação de percepções e imagens contra-hegemônicas.

Ainda no tocante à inscrição interrompida como testemunho do vínculo entre corpo e cidade (e em conexão com os desafios postos pela "consciência da posterioridade"), vale a comparação de "Tragédia urbana" com "Ink on skin", outro poema de Evidências pedestres (p. 52-3)

\section{INK ON SKIN}

Antes, não se trata da velha querela entre abstração e figurativo, mas de como o traço se dispõe no suporte: o lugar no corpo e seu nem-mostra-nem-esconde brincante, dando de si pistas no cós sobe-desce, e

\footnotetext{
${ }^{118}$ Ademais, a entrada da pichação no poema também difere muito do aproveitamento que Bonvicino faz de resíduos textuais da cidade, convertidos às vezes em legenda explicativa para o empilhamento de imagens (ver p. 136 desta tese). Aqui o que importa é mais a performance, o gesto corporal que o texto dele resultante.
} 
na manga impresente, pois sabe que nós que o-

lhamos não sabemos -

(se assim fosse um poema

não caberia lê-lo

por inteiro em nossas

mãos, porém em trechos, de soslaio, na fila

do metrô nas mãos de

quem o tem,

e dão morte

malditas

luzes

e glória debaixo

do arco admirável

da ponte

não sabemos)

mais nada, e

- onde o

fim, onde o começo

No lugar do grafite, surge nesse poema a tatuagem, que, no entanto, por causa da vestimenta e dos movimentos do "corpo em situação", na cidade, também redunda em uma interrupção do legível (que as quebras de palavra ajudam a mimetizar). O eu lírico se apresenta, como em outros poemas do autor, com alta propensão ao voyeurismo - um voyeurismo de tipo particular, que da desorientação algo prazerosa em meio ao "mostra-esconde", ao "sobe-desce" de sinais, procura extrair um método de leitura dos fragmentos em movimento.

Esse método de leitura rapidamente sofre uma inflexão metalinguística no segmento entre parênteses, quando se cogita sua aplicabilidade a poemas. Da mera suposição passa-se então à prova, com a reprodução de fragmentos justapostos de um trecho de "A meditação sobre o Tietê" de Mário de Andrade, poema de Lira paulistana (1945). Combinam-se na reprodução o fragmento de versos da quinta estrofe do poema (“ [...] Estas águas/ São malditas e dão morte, eu descobri! [...]”) com outros da primeira estrofe ("Luzes e glória. É a cidade...” e “[...] Debaixo do arco admirável/Da ponte das Bandeiras o rio”). 
A evocação do líder modernista na remontagem trai decerto um duplo desejo: de filiação, de um lado, e de descolamento, de outro - o que pode ser sintoma daquilo que o autor designa como "consciência da posterioridade". Resta saber, contudo, se essa consciência é crítica, se a relação com o legado modernista implica perplexidade e dúvida em alguma medida.

E uma resposta afirmativa parece possível, já que aqui nada é arbitrário, ao contrário do que ocorria na quimera arquitetônica de "Tragédia urbana". O recurso à montagem de fragmentos não é um procedimento vanguardístico reciclado em chave pós-moderna e aplicado de modo indiferente para extrair o futuro das ruínas. Ele antes decorre do corpo a corpo com a cidade e sua matéria legível, que se oferece "em trechos, de soslaio/ na fila do metrô", em nossas mãos ou nas de outrem.

O poema também pouco tem que ver com aquela apropriação fetichista da erótica textual neobarroca (a fusão arte-vida em escritos sobre o corpo), purgada de sua carga perversa/transgressiva, que Simon e Dantas identificam na poesia de Carlito Azevedo ${ }^{119}$, pois o foco aqui parece incidir menos sobre os escritos que sobre a condição de leitura por eles instaurada na relação com a cidade. Não há violência nem o imaginário sadomasoquista da inscrição como ferida, narrativa que se sobrepõe aos sinais do envelhecimento, mas somente desorientação, uma ignorância sobre "onde é o fim, onde o começo" - desorientação que talvez não seja forçado atribuir não apenas às tatuagens, mas também aos dilemas impostos pela "consciência da posterioridade" (onde acaba o legado moderno? onde começa o contemporâneo?)...

Seguindo ainda com poemas sobre intervenções artísticas na e sobre a cidade, merece também destaque o longo "De uma crítica publicada num suplemento cultural de domingo" (Evidências pedestres, p. 32-5), dividido em quatro partes: "o artista: um retrato", "o artista: um depoimento", "a obra: o conceito"e "nota final".

Em linhas gerais, o poema descreve uma instalação em uma galeria que reproduz o ambiente em que vivem favelados e catadores de papel, sucata. Veem-se por toda parte sacos, latinhas de alumínio, pilhas de papelão, carroças para entulho, bancos de concreto salpicados de excremento, panos puídos e um barraco "autêntico" comprado de moradores de rua "de verdade". A ironia é escancarada, com notas de humor negro (entre os objetos

\footnotetext{
${ }^{119}$ Ver cap. 1, p. 39, nota 17.
} 
há, por exemplo, cobertores encharcados de querosene à espera de um fósforo), momentos de "divertimento" (o público habituado a academias de ginástica penando para puxar as carroças de entulho), misturados a reações mais viscerais, como o vômito de quem "não sabe o que é o inabitável" 120 (categoria em que se inclui o próprio artista) e a garantia (dirigida a interessados com receio da sujeira) de que os visitantes passam por cuidadosa assepsia tão logo saem da sala.

Trata-se, é claro, de uma caricatura da arte alienada, em que não há sutileza ou meias-tintas nem culpa ou moralismo estético, impulso cívico-redentor em relação à pobreza - o que se evidencia sobretudo na última parte, quando se revela que os antigos moradores do barraco, depois de venderem tudo o que tinham para o artista poderiam "regressar ao mato", de onde nunca deviam ter saído, e na observação final sobre a ótima safra do vinho servido na inauguração.

Ainda que o poema se inicie aludindo à tradição do ready made, pela contraposição do artista à ingenuidade dos "dublês de Duchamp", ele logo abandona os problemas de filiação e investe em um tipo de ironia sem ambiguidade, tendendo à caricatura e à piada.

O poema seguinte a esse, "Lembra" (p. 36), evoca a experiência do cubo azul de Ferreira Gullar ${ }^{121}$. Embora não trate da relação entre arte e cidade, fugindo, portanto, ao escopo de nossa discussão, ele contribui para a reflexão sobre o potencial mnêmico das representações artísticas e dos impasses inerentes à consciência da posterioridade. Nele, Ferraz enuncia três vezes o gesto de suspensão do cubo, com progressão na mediação: suspensão no espaço (obra original), no espaço e no tempo (foto do gesto) e no relato poético (“A minha mão/ espaço e tempo suspensos/ segura a mão de Ferreira Gullar”). Essa progressão, que leva do gesto à foto e desta a um novo gesto esboçado no espaço do poema, acaba por produzir um contato inesperado, uma intimidade possibilitada por sucessivos afastamentos e reproduções do gesto original, que, paradoxalmente, recobra sua aura.

Pádua Fernandes, em artigo publicado pouco após o lançamento do livro, refere-se ao conjunto de poemas sobre arte em Evidências pedestres como um núcleo em que

\footnotetext{
${ }^{120}$ A estranheza do público em relação à realidade retratada aparece duas vezes: no final da primeira parte, quando se diz que o artista estimula "sensações inexistentes/ em um público pouco ou nada/ familiarizado com a/ realidade que retrata (p. 32), e no momento do vômito.

${ }^{121}$ O próprio Gullar explica a obra nos seguintes termos: “Então, quando eu fiz o 'livro-poema', eu fiz, ao mesmo tempo, o que era uma estrutura espacial e era manuseável porque era um livro. Então, eu, a partir daí, fiz uma placa branca, botei um cubo azul em cima e escrevi embaixo a palavra: lembra. Então assim, é uma metáfora da lembrança [gesticulando]. Quando você tira o cubo, embaixo está a palavra. Você cobre, a partir daí, aquele objeto que tem uma palavra dentro. Você sabe que, então, não é mais o objeto de antes, ele agora tem uma palavra. Então, eu comecei a fazer. É essa coisa de fazer um poema que a gente mexe com a mão e tal, que leva a um poema" (Gullar, 2001).
} 
aparece, por uma agenda negativa, a vocação social desse livro, igualmente perceptível em De novo nada. Segundo Fernandes, apesar das grandes diferenças estruturais entre os livros, nota-se em ambos "uma tentativa de apreensão das experiências urbanas que evoca o soneto 'A uma passante', de Charles Baudelaire” (Fernandes, 2007, p. 7). ${ }^{122}$

Em sua dissertação de mestrado, Ferraz refere-se ao poema baudelairiano como

[...] um tópos da modernidade, a versão poética dos conceitos expressos no artigo "Le peintre de la vie moderne": "La modernité, c'est le transitoire, le fugitif, le contingent, la moitié de l'art, dont l'autre moitié est l'éternel et l'immuable."

Todavia, a multidão baudelairiana hoje é uma "massa", e ela, aparentemente, não permite identificar indivíduos, muito menos beber nos olhos de alguém um céu lívido no qual se ocultaria um furacão; a vivência pública só existe em termos de consumo e mercado; e a vivência privada beira ao isolamento. Na falta de um flâneur contemporâneo, cabe ao poeta olhar da janela de seu cubo de treva a convulsão da vida e tentar suspender o tempo, como forma não de fuga, mas de compreensão. (Ferraz, 2004, p. 24)

Ferraz procura compreender as condições de sua vigência em contextos urbanos pós-baudelairianos, em que a multidão compacta-se em massa e a flanêrie desaparece ou fica enormemente dificultada. A saída seria então a contemplação distanciada, da janela do “cubo de trevas", e uma suspensão "como forma não de fuga, mas de compreensão". É curiosa a menção ao "cubo de treva" drummondiano (de "Noturno à janela do apartamento", último poema de Sentimento do mundo, 1940), isto é, a adesão a um ponto de vista historicamente recuado, distante das condições urbanas em que se movem as passantes de hoje - o que talvez se ligue à ideia paradoxal de uma suspensão do tempo que não seja fuga, semelhante ao desejo haroldiano de uma agoridade pós-utópica que não enseje uma "poética da abdicação".

Convertido em tópos autônomo em relação ao contexto de origem, Ferraz evoca várias passantes pós-baudelairianas na obra de diferentes escritores, de Stefan Georg e Henri Michaux a Vinícius de Moraes e Haroldo de Campos (Ferraz, 2004, p. 183, nota

\footnotetext{
${ }^{122}$ De Evidências pedestres, Fernandes também menciona o poema "Veja esta dama" (p. 58-9) como exemplo de tributo ao tópos da passante (Fernandes, 2007, p. 7).
} 
404), e propõe que elas sejam entendidas como resultado de diferentes maneiras de "sentir e pensar o tempo, o espaço (variáveis que não cessam de mudar à proporção que o homem muda seu modo de agir sobre o mundo) e a própria forma de expressão poética" (Ferraz, 2004, p. 183). Vejamos então de que maneira Ferraz se apropria desse tópos em De novo nada.

III. A moça do outdoor e a Eurídice do novo: a tentação do inerte

De novo nada é, sem dúvida, o mais ambicioso projeto do autor: longo poema com cerca de seiscentos versos, sobreposição de vozes e um assemblage de citações, diretas e indiretas, reunindo materiais díspares - poetas brasileiros e estrangeiros de diferentes épocas e estilos (muito Drummond, Mário de Andrade, Ferreira Gullar, Haroldo de Campos, Gonçalves Dias... e também Mallarmé e Eliot), prosadores como Joyce e Dostoiévski, citações bíblicas, trechos de canções populares, entre outras coisas. ${ }^{123} \mathrm{Em}$ uma descrição grosseira, o leitor acompanha um jorro de percepções, devaneios, raciocínios, que se cruzam, se atropelam e retornam incessantemente, deflagrados pelo encontro entre certas personagens: um homem mesmerizado pela imagem de uma mulher em um outdoor, o qual tem a sorte lida por uma quiromante, "menos cigana que mendiga", e que encontra por fim, deitada no chão da praça, outra mulher, cujo rosto é coberto por um papel onde se vê a imagem do outdoor. Além dessas quatro personagens (aí incluída a mulher-imagem) outras se acrescentam, mesmo que de modo episódico - por exemplo, o poeta Haroldo de Campos, designado "Haroldo, O-Que-Sabe" (v. 251), alcunha que evoca a tradução feita pelo concretista para o Eclesiastes (Qohélet, O-Que-Sabe).

A leitura de sinais (as linhas da mão do homem, a imagem sem alma do cartaz e, principalmente, a lição dos poetas do passado) em tensão com o ambiente urbano se

\footnotetext{
${ }^{123}$ Só para ter uma rápida ideia, pinço alguns exemplos de citações e alusões: Drummond: "Seria melhor ficar quieto/ num canto (v. 3132); "eu também, em verdade,/sou muito pobre" (v. 121-122); "Povo feio, moreno, bruto/ não respeita o meu costume/preto. Na Europa, sim, reina/ a geometria, e todo mundo anda,/ como eu de luto" (v. 133-137); "Desalmada, a imagem é suave" (v. 228). Bíblia: "Se me dirigisse a Damasco/ me dariam um nome contra/ meu nome? (150-152) e "mulher-pomba oculta numa/cova de rochedo, cujos/ beijos de sua boca nunca/ provei" (v. 289-292); Dostoiévski: "Tenho um terrível amor-próprio,/ sou desconfiado e me ofendo/ com alguma facilidade" (v. 134-136); Gonçalves Dias: "São néscios/ de si mesmos" (v. 137-138); Mallarmé "sem presumir do/ futuro o que sairá, nada ou/ quase uma arte" (v. 249-251); Ferreira Gullar: "Ela amadurece alhures/ certas frutas?", (v. 253-254); "O mundo se perdeu na confu-/ são de tanta noite e tanto/ dia na profusão das coisas" (367-369); Haroldo de Campos: "se lhes disser que ele começa,/ vocês dirão que ele cessa, se lhes disser que ele avança,/ vocês dirão que ele cansa" (v. 515-518).
} 
reapresenta nesse livro em seu grau máximo de complexidade, conforme tentaremos demonstrar.

O poema é escrito em versos livres e lança mão de alguns poucos recursos gráficos para organizar o caudal de vozes: trechos em letras maiúsculas, em maiúsculas e minúsculas, em itálico, em negrito e entre aspas. Ainda que cada "estilo" gráfico não corresponda rigorosamente a determinado personagem ou nível de discurso, poderíamos dizer, grosso modo, que o itálico é usado, na maioria dos casos, para representar a fala da quiromante, o negrito para representar a fala (imaginada) da mulher do cartaz, o texto em estilo redondo/regular representa as falas e pensamentos do homem, seja num registro mais grandiloquente (especulativo, metalinguístico), vazado em maiúsculas, ou mais descritivo, em maiúsculas e minúsculas; reservando-se as aspas para os diálogos com Haroldo-O-QueSabe.

Comentando a estratégia composicional do poema, Fernandes (2007) indica como antecedentes as montagens vocais de T. S. Eliot e a "alternância de reminiscência e reflexões" tal como ocorre no "Poema sujo", de Ferreira Gullar, ambos autores citados por Ferraz em De novo nada. No entanto, embora reconheça originalidade no projeto - que não se limita a parafrasear a passante de Baudelaire nem a evocá-la em uma releitura contemporânea, como fizera Carlito Azevedo, antes convertendo-a em "motivo gerador do discurso poético" -, o crítico denuncia problemas "de dicção, de intertextualidade e de estrutura mal resolvidos". Segundo ele, o poema padeceria de uma "intertextualidade maníaca", em que as citações entram de modo arbitrário ou decorativo, e de certa indiferenciação entre as vozes, que, apesar de múltiplas, adotam muitas vezes um tom elevado, sentencioso - o que se verificaria até na voz da quiromante, que pouco atesta de sua condição de cigana.

No tocante aos problemas de dicção e à homogeneidade das falas, parece que a despersonalização intentada por Ferraz nesse poema, valendo-se do recurso da multiplicação de vozes, não investe na distinção entre os "actantes" para expressar diferenças na posição de classe, marcas de gênero etc. As vozes do poema soam antes como emanações do caminhante em devaneio. A velha-mendiga-cigana-quiromante, por exemplo, desde o início se expressa de um jeito não coloquial, como excessiva correção na escolha dos pronomes e de termos deslocados, feito a palavra "singularidade" logo na 
primeira fala ("sua singularidade/ talvez, está em seu destino", v. 16-7). Ademais, o tom elevado/sentencioso, de fato muito ostensivo nos trechos em maiúsculas, é temperado por cacos de coloquialismo ("Por que não vou prum garimpo e/ troco os coitados de cálcio?", 331-2) e pelo caráter heteróclito dos materiais usados na montagem, que mistura altas divagações teóricas com pedaços de antigas canções ("Se acaso ela/ chegasse no meu Château [...]", v. 442-3).

Mas Fernandes aponta ainda falhas estruturais e gratuidade em certas transições (ele exemplifica com a passagem nos versos 296-7, que comentaremos adiante) e uma recapitulação forçada a partir do verso 560, que não consegue disfarçar os fios deixados soltos pelo meio do caminho. Por fim, o crítico menciona alguns trechos em que a ironia se detém no nível caricatural, o que impede o aprofundamento das reflexões sobre a arte, e conclui afirmando que a "forma do poema longo acabou por superar o fôlego construtivo do poeta".

Sem discordar inteiramente de tal parecer, julgamos que alguns desses "problemas" talvez demandem uma consideração mais detida dos princípios compositivos adotados por Ferraz ou da lógica subjacente às cadeias associativas sobre as quais o poema se ergue.

Ferraz converte a mulher do outdoor em sua nova passante. Uma passante imóvel ou antes deslocada pelos movimentos de quem a contempla em meio ao vaivém das ruas e também pela multiplicação publicitária, que espalha sua efígie por toda a superfície da cidade, vindo mesmo a se substituir ao rosto daqueles a que ela, a cidade, abate (a mendiga caída do final).

Tal mulher parece se inserir em uma longa linhagem, conectando-se a remotas encarnações do feminino, como sugere a reprodução da Vênus de Willendorf na capa do livro. Ela suscita no homem - cuja atitude ecoa "o fantasma de Ulisses passeando pelo cotidiano à procura da própria sorte", conforme explica Viviana Bosi (2007) na orelha da obra - perguntas como “Quem a/ mulher da foto? É de carne?/ Caminha por essas ruas que/ caminho? Paga suas contas/ ao fim de cada mês? Come o/ que como? (v. 192-7).

Embora dirigidas a uma superfície inerte, as perguntas deflagram uma reposta da mulher-imagem, que, ao se manifestar, se oferece como sucedâneo do poema: “Que lixo. A palavra/ dentro do poema incapaz de/ valer-se como palavra. A-/ gora, imagem por imagem/ eu mesma já sou um poema”. (v. 199-203). 
O tempo suspenso na imagem passa então a funcionar como análogo da agoridade permansiva da poesia pós-utópica (e com a totalidade sem fissuras das cidades museificadas, com o ímpeto congelante do preservacionismo patrimonial). Um tempo atulhado de citações em que só é possível se alimentar de papel ("Coma esta resma [...] escolha como/ sairão de seu corpo as letras", v. 20, 24), em que o "real é prescindível" (v. 47) e a "mudez é absoluta" (v. 65). Tempo morto da imagem eternizada sem vísceras (“ [...] encarcerada/ por objetivas Yashika/ que na superfície plana/ a eternizam sem vísce-/ ras nessa torre? [...], v. 209-213) nem alma ("Desalmada, a imagem é suave”, v. 228, que evoca o drummondiano "E sem alma, corpo, és suave") e que reverbera no diálogo com os mortos como inerente à consciência da posterioridade, quando a nostalgia do novo impõe um tipo de catábase, de descida aos subterrâneos da tradição.

Essa equivalência entre a inércia da imagem ${ }^{124}$ e a paralisia poética se evidencia com força na passagem em que Haroldo de Campos aparece e se afirma que o novo foi sua Eurídice (v. 248-287):

[...] Quem tem ego para ver o que vejo sem presumir do futuro o que sairá, nada ou quase uma arte, daqui? Haroldo, OQue-Sabe, me deu conselhos:

"-Ela amadurece alhures certas frutas"? Ele bebeu do vinho da vaidade, quis o dia que virá, quis fazer de si o dia que virá, mudando os dias já vividos, e quando o dia veio, pegou-o no passado, sua Eurídice foi o novo.

“- De repente se nos mostra o novo: este novo. Novo, contudo, agora deixou de ser. Logo, vemos que o novo, a novidade do que é novo, reside, com efeito, nisso: não mais ser. $\mathrm{O}$ novo que antes se mostrava era um ter-sido." Assim me disse o velho Haroldo,

${ }^{124}$ Imagem cujo estatuto é ensejo para longas reflexões, indo da distinção da filosofia clássica entre imitação ecástica e imitação fantástica (v. 343) a digressões sobre a sociedade de consumo. 
sem sílaba sequer sobre o

neo-novo, novo que é sempre

novo e que é sem nem ter sido, que é sem vir a ser, do nada nascido e o nada gerando, sem começo nem fim, tudo sempre meio. " - Velho, sem tempo que é do homem no instanteagora?

Sol extático? Rio corrente que não corre? Sempre novo que é sempre o mesmo?" "- Se é eterno?

Não, só inerte. Sem ter sido não poderá vir a ser, e o que é aparenta ser, frauda o fato de existir, pois que no viver implica o agir para mudar, sempre ser é como ser imagem de um outdoor. [...]"

A associação entre o nome do poeta concretista e o título por ele dado a sua transcriação do Eclesiastes conecta a estagnação pós-utópica ao "nada de novo sob o sol" do poema bíblico, de que Ferraz também se apropria como título ${ }^{125}$.

Ferraz serve-se aqui de Mallarmé e seu poema constelar, marco pós-moderno, e dos poemas bíblicos traduzidos por Haroldo (não apenas o Qohélet, mas também o Shir Hashirim (v. 291) ${ }^{126}$ para enfatizar o nexo entre o novo e a morte, a amada morta (Eurídice).

Todavia, a voz que conversa com o poeta conselheiro indaga sobre a possibilidade de um "neo-novo", que é "sem nem ter sido", sem vir a ser". Quer saber o que será do homem no "instanteagora" sem tempo. A resposta que obtém é desanimadora: o homem do "instanteagora" é como a imagem do outdoor: inerte sem ser eterna, sem vir a ser e sem ter sido, assim como sem presente, que implicaria o "agir para mudar".

Mas o poema não se detém nessa melancólica constatação da inércia mortífera resultante do tesão pela mulher do outdoor e pela Eurídice do novo, pois essas mortas sem vísceras, embalsamadas, são contrapostas aos mortos insepultos da cidade viva. De um

\footnotetext{
${ }^{125}$ Sem esquecer tampouco a retomada eliotiana desse tópos da repetição sem fim em The Waste Land ("Nothing again nothing", "A game of chess", v. 129), conforme esclarece Viviana Bosi na orelha de De novo nada. Beckett também o visitaria na abertura de Murphy ("The sun shone, having no alternative, on the nothing new").

${ }^{126}$ Com algum senso diversionista, é claro. A primeira frase de Haroldo-O-Que-Sabe, por exemplo, ("Ela amadurece alhures certas frutas") reproduz versos de Ferreira Gullar, do poema “O quartel”, de A luta corporal (1954).
} 
lado, há sim, o erotismo do papel (“Coma esta resma ...”) e da imagem sem lastro, que dispensam o real e fazem com que o impossível utópico ("Soyons réalistes, demandons l'impossible", lema do maio de 1968) recue para o interior do pensamento (só o impensável é impossível).

De outro, porém, há a interrupção imposta pela cidade atual, com suas sirenes, sua poluição, o monturo e os cadáveres que dificultam a leitura, a contemplação do outdoor, o resgate de Eurídice (v. 110-7):

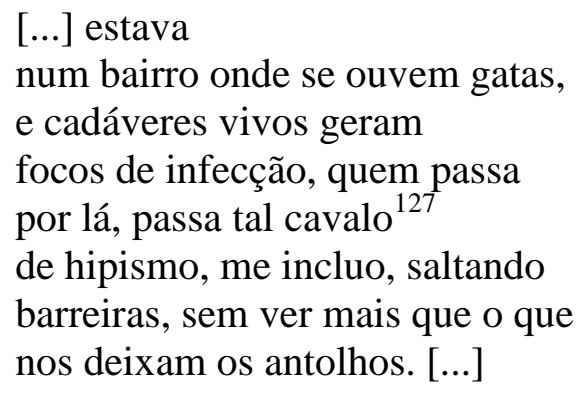

Mais adiante, a menção ao edito de Creonte ("Ninguém revogou o edito/ proclamado por Creonte", v. 142-3), que em Sófocles refere-se à proibição do sepultamento de Polinice, considerado traidor de Tebas, aplica-se aos corpos insepultos sobre a calçada, que o caminhante salta como em uma prova de barreiras ${ }^{128}$, e que vão retornar no corpo da miserável que o poeta encontra no fim do poema, com o rosto coberto pela foto da musa do cartaz.

Ferraz então parece controlar o fluxo caudaloso de associações comparando o tempo lento da calçada (suja, barulhenta, coalhada de obstáculos) à presentidade casta e abstrata da imagem. Trata-se de uma comparação com desdobramentos os mais variados. Por exemplo, ao fim da conversa com Haroldo, o homem indaga se está doente por se enredar em tantas frases feitas e lugares-comuns. Pergunta a que ele mesmo responde, dizendo que doente "é quem come merda e/ caga casto, quem a sola/ dos sapatos limpa ao sair de/ casa" (v. 297-300).

\footnotetext{
${ }^{127}$ Alguns versos antes, a imagem do cavalo, em chave subjetiva (“o cavalo interno”) aparecia, aplicada à pressão exercida pelas imagens da agoridade: "O a-/ gora nunca nos dá trégua, as/ rédeas do cavalo interno/ desata e a seu ventre ferra/ com imagens do que não pode/ ter" (v. 42-7).

${ }^{128}$ Imagem já empregada no poema "Vivência", de Ronald Polito, comentado no cap. 1, p. 50.
} 
Ao se ocupar dos problemas na construção do poema, Fernandes (2007) refere-se ao caráter gratuito da transição anterior. Julgamos, porém, que se conecta à menção da escrita como evacuação ("esta resma alimenta/ seu ventre e enche os intestinos, [...] escolha como/ sairão de seu corpo as letras", v. 21-5) em confronto com uma abertura para o pasto impuro da rua (comer papel $\times$ comer merda), que se traduz pela adesão ao reles, ao comum.

Ademais, a ideia dos sapatos limpos, que se segue à castidade evacuativa, retoma ainda a oposição entre a imagem sem vísceras e as impurezas da rua, além de preparar o elo seguinte da cadeia associativa, em que os mortos falam pela boca dos vivos (" [...] Falo a fala morta/ do morto, viva na boca/ dos - seja minha seja de outro -/ vivos [...]”, v. 300-3) - talvez por causa do antigo costume de limpar o sapato dos mortos. Câmara Cascudo explica que os sapatos são limpos "para que não levem poeira, terra, areia. Levando qualquer areia, a alma volta, saudosa, atraída pela recordação da família” (Cascudo, 1962, p. 162, verbete “Cadáver”). Descontando a estranheza pelo fato de a limpeza ser feita não ao voltar da rua, mas ao sair de casa, talvez seja lícito ver aí um pacto com os mortos do cânone, suaves como a imagem do outdoor, em oposição aos cadáveres da calçada, sobre os quais se salta com sapatos imaculados.

Contraste semelhante se estabelece entre a língua morta na boca do homem e o dente de ouro na boca da quiromante mendiga ("Posso ver, no/ breu da boca, o ouro roubado", v. 324-5, "Dentes/ de ouro resistem ao açúcar?/ Por que não vou prum garimpo e/ troco os coitados de cálcio?”, v. 329-32). Eis um contraste curioso, pois o ouro surge como um sucedâneo da eternidade, mas de uma eternidade que convive com o breu e a cárie e que só pode ser conquistada mediante esforço mundano (roubo, troca, garimpo).

Um pouco mais adiante, o encontro entre o tempo vivo da cidade e o tempo morto da imagem ressurge na cena em que o homem contempla a própria imagem não no "severo espelho", e sim no vidro das vitrines (fundindo-se ao gesso dos manequins) e nos para-brisas dos carros (v. 343-364). Novamente aqui temos, de um lado, o tempo lento do pedestre, atendido pela balconista suburbana e casadoira atrás da vitrine, e, de outro, a imobilidade dos manequins e o deslocamento veloz dos carros, aos quais os outdoors se revelam com mais clareza.

De certa maneira, a sobreposição da imagem do homem ao manequim também antecipa a cena final, em que a publicidade cobre o rosto da mulher caída. O poema é cheio 
de filigranas, circunvoluções, ecos internos que demandariam maior detalhamento. No entanto, o que pretendemos ressaltar é a estratégia geral adotada pelo autor nessa obra, e que consiste em:

a) atualizar o tópos da passante conectando-o simultaneamente à reflexão sobre a atemporalidade na imagem publicitária, que hipnotiza o espaço público, e à falta de saídas da poesia pós-utópica, em que as vozes do passado sitiam a garganta dos vivos;

b) erotizar as figuras da atemporalidade, convertidas em verdadeiros súcubos, de modo a explicar sua força atrativa,

c) perturbar o transe hipnótico e a possessão pelo extemporâneo por meio do atrito com a cidade concreta e contemporânea, com suas calçadas cheias de lixo e cadáveres insepultos (que substituem a antiga flânerie pela "amarelinha do fim do mundo" conforme observamos anteriormente a propósito do poema "Vivência", de Ronald Polito), seu espaço disputado entre pedestres (ciganas, balconistas...) e automóveis etc.

Claro que essa crispação trazida pelos dados contingentes do ambiente urbano não constitui novidade de per si, pois de há muito o canto dissonante das sereias da tradição moderna convive com as sirenes de ambulância e de polícia - assim como o lixo, a publicidade, o atropelo dos automóveis compõem há tempos o morse urbano "recifrado" pelos poetas. Sem embargo, a novidade, relativa, se prende à erotização/feminização da tradição poética e do espaço público, reduzido à sua dimensão publicitária, cuja face mórbida (a força inercial) é contrabalançada pela percepção de outros aspectos da cidade concreta, sobretudo a aceleração gravitacional da miséria e de suas "antimusas" (a quiromante, a balconista, a mulher caída).

E a estratégia aqui não se confunde com a polarização maniqueísta entre publicidade e miséria, como em alguns poemas de Página órfã, de Régis Bonvicino ${ }^{129}$, nem com a erotização/morbidização da cidade praticada por Pádua Fernandes para acentuar e

\footnotetext{
${ }^{129}$ Aproveitando o fato de que De novo nada e Página órfã foram lançados no mesmo ano, Manuel da Costa Pinto (2007) compara a reflexão social da poesia de Ferraz à ambição "participante" do poeta magistrado, enfatizando a radicalidade meramente retórica do segundo: “ [...] o eterno repetidor dos concretos tenta dar, com ligeiro atraso, o 'salto participante' proposto por Décio Pignatari nos anos 60”. (Costa Pinto, 2007). A crítica é obviamente maldosa, ainda que atine com os limites do projeto bonviciniano.
} 
perverter elementos da retórica higienista e do discurso ideológico sobre o funcionamento do "corpo social", conforme explicamos no capítulo anterior. Em De novo nada, embora haja ironias em relação à segregação urbana e ao higienismo social (por exemplo, na cena final, quando se diz que o cobertor de papel e plástico improvisado pelos "dormidores públicos" constitui um "método barato de limpar as ruas", v. 581-2), o recurso às figuras femininas, por vezes operando em chave mítica, e às imagens mortíferas da calçada serve antes para resistir ao fascínio da repetição consumista (consumo das imagens e do legado da tradição moderna, concretista, marginal) no intervalo possível entre a máscara massificante e o rosto dos que caíram.

Com base nas análises anteriores, vimos como a imagem da queda comparece em vários poemas de Ferraz (o pombo esmagado ao fim da suíte "Ensaio fotográfico", a demolição do palacete-cortiço em "Vagas para rapazes", o acidente com o pichador em "Tragédia urbana"), ressurgindo de modo inesperado na cena final de De novo nada.

Fernandes (2007), no desfecho de sua resenha sobre o livro, depois de identificar os limites à vocação social nos poemas de Ferraz (falta de fôlego construtivo, em De novo nada, e pouco além de ironias à arte alienada, em Evidências pedestres) afirma que se deveria esperar mais dessa poesia, pois "sob a imagem da mulher do outdoor [...] nenhum sem-teto ainda consegue despertar". Uma poesia que desperte/levante os que caíram: tal expectativa não trai certo moralismo estético, uma perspectiva cívica e redentora para a arte? Compete mesmo aos poetas esse soerguimento?

De todo modo, qualquer que seja a resposta que se dê a tais perguntas, importa verificar o papel desempenhado pela queda nesses poemas, sua capacidade de tensionar o tempo congelado pela lógica do espetáculo e da publicidade, pelo fetiche do passado da cidade e da língua, de desatar o agouro e deslindar o calendário, abrindo-se à urgência das ruas, onde os meios de aniquilamento sofrem contínuo aprimoramento.

No tocante a poemas como "Ink to skin" e "De novo nada", ressalte-se, enfim, a inflexão de rumo por eles permitida. Preocupamo-nos a maior parte do tempo em verificar se e como transformações recentes na forma de produzir o espaço urbano são captadas pela 
poesia contemporânea. Com Ferraz, contudo, pudemos também fazer o caminho inverso, isto é, perceber como a cidade permite à consciência da posterioridade encenar seus dilemas, ou seja, como as novas demandas advindas da rua galvanizam a relação da poesia com os poetas pretéritos, intuindo um rosto inédito sob o jornal de ontem. 


\section{Considerações finais}

E ao que chegamos ao fim desse périplo por ruas e calçadas, viadutos e marquises, bunkers, outdoors, plataformas de embarque, sinais fechados, tiroteios, casas-vala, espaços de consumo e aniquilamento?

Entre os objetivos que nos propusemos no início, estava o de verificar se importantes transformações no âmbito das cidades brasileiras (incremento nos índices de violência e criminalidade, colapso dos sistemas de transporte, aumento do déficit habitacional para a população de baixa renda, aumento do número de moradores de rua etc.) afetavam a maneira pela qual os poetas contemporâneos as enxergavam.

Claro que, desde o começo, a preocupação maior foi a de lastrear o recorte de análise para além do temático, pensando nesses problemas urbanos não como elementos exteriores aos poemas, mas como conteúdos sociais "precipitados em forma". Por essa razão, a pergunta sobre diferenças no modo de representar a cidade levou em conta a maneira pela qual seus conflitos e tensões conduziam eventualmente a desequilíbrios temático-expressivos, isto é, a soluções que abafavam ou amplificavam as forças em luta no poema.

Além disso, procuramos aquilatar as estratégias de representação do espaço urbano por meio de comparações com soluções mobilizadas pela poesia pretérita ocupada de questões afins. Tais comparações permitiram constatar sejam empréstimos de soluções caducas, inadequadas à situação de hoje, sejam saídas “originais" que, mesmo valendo-se de recursos da tradição, servem-se deles sem arbitrariedade, de um jeito motivado pelas exigências da matéria a conformar.

Assim, este trabalho sobre as representações do espaço urbano na poesia pós-1990 constitui também uma reflexão sobre o diálogo da poesia contemporânea com seus antecedentes novecentistas, no caso das saídas originais, ou sobre o fenômeno da ventriloquia (a voz dos mortos na boca dos vivos), nos casos de repetição estéril, consumo passivo e combinação arbitrária de formas pretéritas.

Afora a atenção para as mudanças históricas no modo de representar a cidade, percebidas muitas vezes por intermédio de confrontos com o passado, frequentemente também nos perguntamos sobre o possível papel contraideológico exercido por essas 
representações poéticas da cidade tendo em vista os discursos hegemônicos sobre os espaços públicos residuais, a publicidade, os sem-teto, as intervenções artísticas no ambiente urbano, entre outros assuntos.

Tentando especificar um pouco mais alguns critérios de que nos servimos no decorrer das análises, merecem destaque as preocupações com o ponto de vista (aproximado ou distante, estático ou móvel, íntegro/sinóptico ou fraturado, parcial). A consideração da perspectiva foi importante, por exemplo, na comparação entre Melo e Bonvicino, nos poemas sobre moradores de rua: enquanto neste a estabilidade escópica se associa a uma atitude pictural e enumerativa, que descreve as cenas de rua como naturezas-mortas, abstraindo os condicionantes concretos do desabrigo, naquele, o descritivismo é temperado por sucessivas correções no ângulo de observação (alternância entre planos fechados, rentes ao ponto de vista das coisas e personagens descritas e subordinação da dimensão escópica à dinâmica gestual, tolhida ou acelerada pelo medo, refém dos automatismos).

Outro aspecto importante considerado nas análises foi a maneira pela qual a forma poética lida com os antagonismos de classe que convertem o espaço urbano em território disputado. Tais antagonismos parecem abalar em muitos casos a coesão do eu lírico, precipitando-o rumo à indiferenciação (a fusão com a paisagem natural em Polito) ou à despersonalização por multiplicação de vozes (a inflexão para o dramático, não realizada de modo completo, em Sterzi, e a estrutura polifônica presente nos poemas de Fernandes e Ferraz). Em outros casos ainda, sem que haja polifonia ou cisão da voz lírica, os antagonismos são trabalhados por meio de polaridades no plano das imagens, como as oposições entre mobilidade e resistência (dos materiais, no trabalho manual, da própria cidade, nos fluxos bloqueados), rotina e insônia, esmola e comércio, travessia e estase, conforme vimos na poesia de Alberto Martins.

A combinação entre procedimentos experimentais/vanguardísticos (como a espacialização visual e o criptograma) e a narratividade prosaica foi outro recurso utilizado por diferentes poetas, com resultados díspares. Em "Tatuagem enigmática”, de Duda Machado, interrogamo-nos sobre o efeito da abstração visual do criptograma à paródia jornalística que o elucida. Aventamos então a hipótese de uma neutralização da violência encriptada na tatuagem pela consumação do jogo decodificatório proposto pelo poema. Já 
no poema do cupim, de Pádua Fernandes, observamos como a espacialização vertical do poema, que mimetiza o túnel aberto pelo cupim, introduz uma nota de novidade no velho recurso da technopaegnia e, combinando-se de modo inaudito a outros traços da tradição literária, configura uma apropriação distópica de um procedimento de vanguarda coerente com as intenções expressivas do autor. Notamos também algo semelhante na montagem de fragmentos textuais realizada por Ferraz em "Ink on skin", mostrando que o uso daquele expediente ali não se devia à reciclagem arbitrária de um procedimento "vanguardístico", decorrendo antes das condições de legibilidade instauradas pelo embate corpóreo com a cidade real, palco de solavancos e interrupções.

Um quarto aspecto passível de evocação prende-se ao uso da metáfora. Logo no primeiro capítulo, ao tratar dos impasses na figuração da violência enfrentados pela poesia pré-1990, lembramo-nos da metáfora auroral empregada por Drummond ao fim de "Morte do leiteiro", evocando o parecer de um crítico para o qual o fecho lírico da composição assinalaria um limite formal para expressar "a violência resultante do consórcio entre trabalho e desigualdade". Colocando assim sob suspeita um dos mais tradicionais recursos à disposição dos poetas, especulamos sobre o potencial crítico da metáfora nos poetas de nossa amostra. Nos homens-fósseis de Tarso de Melo, por exemplo, procuramos demonstrar como a metáfora paleontológica não empana a "percepção das condições que engendram o desalento (o dia solar e industrioso, a noite de esvaziamento e fuga, a restrição da vida ao campo do trabalho, os anúncios de fracasso econômico etc.)”, a despeito da natureza biológica da imagem que transfigura a realidade factual. De modo semelhante, também nos referimos às metáforas corporais da cidade-mulher em Fernandes, que por meio delas revela a faceta mais sombria da segregação territorial da pobreza, e à dupla erotização nas imagens urbanas de Ferraz, que contrapõe aos súcubos da publicidade e às Eurídices haroldianas as antimusas que a cidade abate sem sepultar.

Eis apenas alguns exemplos que não esgotam a diversidade nem a complexidade das estratégias representacionais mobilizadas pelos poetas de hoje, confrontados pelas novas formas urbanas. Não é possível atinar com as implicações estéticas e ideológicas desses recursos fora da interseção entre técnica, tessitura imagética, posição e atitude do sujeito lírico, que se produz de modo singular em cada poema. Por conseguinte, é arriscado afirmar que a estrutura polifônica e a perspectiva aproximada são em si mais contraideológicas que 
a voz unitária e o ponto de vista recuado, já que ficar ao pé dos "excluídos" também pode ter efeitos contraditórios, de tipo kitsch, estetizante, ideologizante.

Tampouco devemos subestimar as formas de representação indireta de angústias socialmente produzidas, que evitam o "fetiche do factual" sem enveredar pela recusa mimética, apostando antes na desestabilização (mais que na supressão) da referência, nos termos propostos por Simon e Dantas (2009) - o que também se liga à hipótese de um realismo de tipo experimental, desvinculado da ideia estrita de verossimilhança, um realismo que incorpora dispositivos da vanguarda não para atestar a artificialidade da representação e a impossibilidade de qualquer tipo de mimese, mas para indiciar o real de modo descontínuo e performativo.

De toda maneira, e com isso encerramos, cremos ter reunido elementos suficientes para entender um pouco melhor os múltiplos caminhos desse retorno ao real empreendido por uma parcela da poesia brasileira contemporânea, que, olhando para trás, não lamenta, como Orfeu, a perda de Eurídice nem reivindica sua herança, pois, à frente, a rua está de novo cheia, pedindo passe livre para quem vem chegando. 


\section{REFERÊNCIAS}

\section{Obras poéticas}

AlviM, Francisco. O metro nenhum. São Paulo: Companhia das Letras, 2011.

Andrade, Carlos Drummond de. Poesia completa. Rio de Janeiro: Nova Aguilar, 2003.

Andrade, Mário de. Poesias completas. 4. ed. São Paulo: Martins, 1974.

BonVICINO, Régis. Até agora. São Paulo: Imprensa Oficial, 2010.

. Céu-eclipse. São Paulo: Ed. 34, 1999.

Página órfã. São Paulo: Martins Fontes, 2007.

FERnANDES, Pádua. Cálcio. Lisboa: Averno, 2012.

. Cinco lugares da fúria. São Paulo: Hedra, 2008.

FERraZ, Paulo. Constatação do óbvio. São Paulo: Sebastião Grifo, 1999.

Evidências pedestres. São Paulo: Sebastião Grifo, 2007.

. Meu sol, minha primavera. São Paulo: Sebastião Grifo, 2011. Plaquete fora de comércio, em tiragem limitada de 50 exemplares.

FERRAZ MELlO, Heitor. Um a menos. Rio de Janeiro: 7letras, 2009.

Galvão, Donizete. Mundo mudo. São Paulo: Nankin, 2003.

Machado, Duda. Crescente (1977-1970). São Paulo: Duas Cidades. 1990. (Col. Claro enigma).

. Margem de uma onda. São Paulo: Ed. 34, 1997.

Martins, Alberto. Cais. São Paulo: Ed. 34, 2002.

. Em trânsito. São Paulo: Companhia das Letras, 2010.

. Poemas. São Paulo: Duas Cidades, 1990. (Col. Claro enigma).

MELo, Tarso de. Carbono. São Paulo: Nankin, 2002.

. Exames de rotina. Florianópolis: Ed. da Casa, 2008.

. Lugar algum (com uma Teoria da poesia). São Paulo: Alpharrabio, 2007.

. Planos de fuga e outros poemas. São Paulo: Cosac Naify, 2005.

POLITO, Ronald. Intervalos. Rio de Janeiro: Sette Letras, 1998.

. Terminal. Rio de Janeiro: 7letras, 2006. (Col. Guizos).

RoQueTte-PInTO, Cláudia. Margem de manobra. Rio de Janeiro: Aeroplano, 2005.

STERZI, Eduardo. Aleijão. Rio de Janeiro: 7letras, 2009.

VAnZOLInI, Paulo. Tempos de cabo. São Paulo: Imprensa Oficial do Estado, 2009. 


\section{Urbanismo e antropologia urbana}

\section{Livros e trabalhos acadêmicos}

AUGÉ, Marc. Não-lugares: introdução a uma antropologia da supermodernidade. 7. ed. São Paulo: Papirus, 2008.

. Por uma antropologia da mobilidade. São Paulo: Ed. Unesp; Maceió: Edufal, 2010.

BAuman, Zygmunt. Confiança e medo na cidade. Rio de Janeiro: Jorge Zahar, 2009.

Brito, Felipe; OliveIRA, Pedro Rocha de. Territórios transversais. In: MARICATO, Ermínia et al. Cidades transversais: Passe Livre e a manifestações que tomaram as ruas do Brasil. São Paulo: Boitempo; Carta Maior, 2013.

CAIAFA, Janice. Aventura das cidades: ensaios e etnografias. Rio de Janeiro: Ed. FGV, 2007.

Jornadas urbanas: exclusão, trabalho e subjetividade nas viagens de ônibus na cidade do Rio de Janeiro. Rio de Janeiro: Ed. FGV, 2002.

CAldeIRA, Teresa. Cidade de muros: crime, segregação e cidadania em São Paulo. 2. ed. São Paulo: Ed. 34; Edusp, 2003.

. Inscrição e circulação: novas visibilidades e configurações do espaço público em São Paulo. Novos Estudos, São Paulo, n. 94, nov. 2012.

O rap e a cidade: reconfigurando a desigualdade em São Paulo. In: KOWARICK, Lúcio;

MARQues, Eduardo. São Paulo: novos percursos e atores (sociedade, cultura, política). São Paulo: Ed. 34; Centro de Estudos da Metrópole, 2011.

DAVIS, Mike. Planeta favela. São Paulo: Boitempo, 2006.

DELGADO, Manuel. El espacio público como ideologia. Madrid: Los libros de la catarata, 2011.

DI FELICE, Massimo. Paisagens pós-urbanas: o fim da experiência urbana e as formas comunicativas do habitar. São Paulo: Annablume, 2009.

Feltran, Gabriel de Santis. Fronteiras de tensão: política e violência nas periferias de São Paulo. São Paulo: Ed. Unesp; Centro de Estudos da Metrópole; Cebrap, 2011.

FIORI ARANTES, Otília Beatriz. O lugar da arquitetura depois dos modernos. 3. ed. São Paulo: Edusp, 2000.

- Urbanismo em fim de linha e outros estudos sobre o colapso da modernização arquitetônica. 2. ed. São Paulo: Edusp, 2001.

Flusty, Steven. Building Paranoia. In: Ellin, N.; Blakely, E. J. (Orgs.). Architecture of fear. New York: Princeton Architecture Press, 1997.

GIUCCI, Guilhermo. A vida cultural do automóvel: percursos da modernidade cinética. Rio de Janeiro: Civilização Brasileira, 2005. 
JACQUES, Paola Berenstein. Estética da ginga: a arquitetura das favelas através da obra de Hélio Oiticica. 3. ed. Rio de Janeiro: Casa da Palavra, 2007.

Zonas de tensão: em busca de micro-resistências urbanas. In: JACQUES, Paola Berenstein; DUlTRA BRITTO, Fabiana (Orgs.). Corpocidade: debates, ações e articulações. Salvador: EDUFBA, 2010.

JEUDY, Henri-Pierre. Espelho das cidades. Rio de Janeiro: Casa da Palavra, 2005.

. Reparar: uma nova ideologia cultural e política. In: JEUDY, Henri-Pierre; JACQUES, Paola Berenstein (Orgs.). Corpos e cenários urbanos. Salvador: EDUFBA, 2006.

KoOLhaAs, Rem. Espacio basura. Barcelona: Gustavo Gili, 2007.

Por uma cidade contemporânea. In: NeSBITT, Kate (Org.). Uma nova agenda para a arquitetura: antologia teórica (1965-1995). São Paulo: Cosac Naify, 2006.

LEFÈVRE, José Eduardo de Assis. O papel do transporte coletivo como agente transformador da estruturação do centro da cidade de São Paulo. Dissertação (Mestrado) - Faculdade de Arquitetura e Urbanismo, Universidade de São Paulo, São Paulo, 1985.

MARICATO, Ermínia. Brasil, cidades: alternativas para a crise urbana. 2 ed. Petrópolis: Vozes, 2002.

et al. Cidades transversais: Passe Livre e a manifestações que tomaram as ruas do Brasil. 1 ed. São Paulo: Boitempo: Carta Maior, 2013.

O automóvel e a cidade. In: . O impasse da política urbana no Brasil. Petrópolis: Vozes, 2011.

MongIN, Olivier. La condition urbaine: la ville à l'heure de la mondialisation. Paris: Éditions du Seuil, 2005.

MOVIMENTO PASSE LIVRE. Não começou em Salvador não vai terminar em São Paulo. In: MARICATO, Ermínia et al. Cidades transversais: Passe Livre e a manifestações que tomaram as ruas do Brasil. São Paulo: Boitempo; Carta Maior, 2013.

PAQUOT, Thierry. Debout, assis, couché: entre béton et bitume. In: Des corps urbains: sensibilités entre béton et bitume. Paris: Autrement, 2006.

. L'espace public. Paris: La Découverte, 2009.

PEREIRA, Alexandre Barbosa. Pichando a cidade: apropriações "impróprias" do espaço urbano. In: MagnANI, José Guilherme Cantor; MANTESE DE SouZA, Bruna (Orgs.). Jovens na metrópole: etnografias de circuitos de lazer, encontro e sociabilidade. São Paulo: Terceiro Nome, 2007.

RISÉRIO, Antonio. Sertão, cidade, segregação. In: A cidade no Brasil. São Paulo: Ed. 34, 2012.

SANSOT, Pierre. Poétique de la ville. Paris: Payot, 2004.

SIMMEL, Georg. A metrópole e a vida mental. In: VelHo, Otávio Guilherme. O fenômeno urbano. 4. ed. Rio de Janeiro: Zahar, 1979, p. 11-25. 
SNow, David A.; ANDERSOn, Leon. Desafortunados: um estudo sobre o povo da rua. Petrópolis: Vozes, 1998.

Telles, Vera da Silva; HiRATA, Daniel. Cidade e práticas urbanas: nas fronteiras entre o ilegal, o informal e o ilícito. In: KowARICK, Lúcio; MARQUES, Eduardo. São Paulo: novos percursos e atores (sociedade, cultura, política). São Paulo: Ed. 34; Centro de Estudos da Metrópole, 2011.

Valadares, Licia. Favela. In: Topalov, Christian et al. L'aventure des mots de La ville. Paris: Robert Laffont, 2010.

VASCONCELlos, Eduardo Alcântara de. Circular é preciso, viver não é preciso: a história do trânsito na cidade de São Paulo. São Paulo: Annablume, 1999.

. Transporte urbano nos países em desenvolvimento: reflexões e propostas. 4. ed. São Paulo: Annablume, 2000.

VASSET, Philippe. Un livre blanc. Paris: Fayard, 2007.

VILlAÇA, Flávio. O espaço intra-urbano no Brasil. São Paulo: Studio Nobel; Fapesp; Lincoln Institute, 1998.

. Reflexões sobre as cidades brasileiras. São Paulo: Studio Nobel, 2012.

VIRILIO, Paul; LOTRINGER, Sylvere. Guerra pura: a militarização do cotidiano. São Paulo: Brasiliense, 1984.

WISNIK, Guilherme. Estado crítico: à deriva nas cidades. São Paulo: Publifolha, 2009.

\section{Suplementos, jornais, periódicos, blogues e legislação}

Alves Filho, Francisco; AQuino, Wilson. A morte no lixão. IstoÉ Brasil, n. 2109, 9 abr. 2010. Disponível em: <http://www.istoe.com.br/reportagens/64153_A+MORTE+NO+LIXAO>. Acesso em: 2 out. 2011.

AMADO, Guy. "Griffiti" ou a transgressão domesticada. Revista Número, n. 6, 2007. Disponível em: <http://artonauta.wordpress.com/2011/02/17/griffiti-ou-a-transgressao-domesticada>. Acesso em: 1 nov. 2011.

Amaral, Marina. Panela de pressão. Revista do Brasil, ed. 56, 11 fev. 2011. Disponível em: <http://www.redebrasilatual.com.br/temas/cidades/revistas/56/panela-de-pressao>. Acesso em: 1 abr. 2012.

ANTP (Associação Nacional de Transportes Públicos). Pesquisa de Imagem dos Transportes na Região Metropolitana de São Paulo 2011. Disponível em: <http://portall.antp.net/site/ pesquisa/default.aspx>. Acesso em: 19 maio 2012.

BALAZINA, Afra. Rampa antimendigo causa polêmica na área social. Folha de S.Paulo, 5 jan. 2006. Caderno Cotidiano. Disponível em: <http://www1.folha.uol.com.br/fsp/cotidian/ff0501200614.htm>. Acesso em: 1 nov. 2011. 
BALESTRERI, Ricardo; SoARES, Luiz Eduardo. A raiz dos nossos problemas de segurança. Folha de S.Paulo, 18 maio 2012, p. A3. Disponível em: <http://www1.folha.uol.com.br/fsp/opiniao/43492-araiz-dos-nossos-problemas-de-seguranca.shtml>. Acesso em: 20 maio 2012.

Biderman, Ciro; Zarattini, Carlos. O apagão no transporte de São Paulo. Folha de S.Paulo, 10 abr. 2012, p. A3. Disponível em: <http://www1.folha.uol.com.br/fsp/opiniao/36134-apagao-notransporte-de-sao-paulo.shtml>. Acesso em: 19 maio 2012.

BonduKI, Nabil. O modelo de desenvolvimento urbano de São Paulo precisa ser revertido. Estudos Avançados, São Paulo, v. 25, n. 71, jan./abr. 2011.

BRASIL. Lei 12.587, de 3 de janeiro de 2012. Disponível em: <http://legislacao.planalto.gov.br/ legisla/legislacao.nsf/Viw_Identificacao/lei\%2012.587-2012? OpenDocument>. Acesso em: 20 maio 2012.

BRASIL. Ministério das Cidades. Secretaria Nacional de Habitação. Déficit habitacional no Brasil 2008. Brasília, 2011.

Brasil. Ministério do Desenvolvimento Social e Combate à Fome. Pesquisa Nacional sobre a População em Situação de Rua, abr. 2008. Disponível em: <http://www.mds.gov.br/ backup/arquivos/sumario_executivo_pop_rua.pdf>. Acesso em: 21 out. 2011.

CAlDEIRA, Teresa. Medo da cidade. Disponível em: <http://p.php.uol.com.br/tropico/html/ textos/330,1.shl>. Acesso em: 16 jan. 2009.

CHEGA ao fim a demolição do São Vito, famosa favela vertical de SP. Folha de S.Paulo, 3 maio 2011. TV Folha. Disponível em: <http://www1.folha.uol.com.br/multimidia/videocasts/910459chega-ao-fim-a-demolicao-do-sao-vito-famosa-favela-vertical-de-sp.shtml>. Acesso em: 1 jul. 2013.

Como resolver o trânsito nas grandes cidades? (enquete). AU - Arquitetura e Urbanismo, ed. 170, maio 2008. Disponível em: <http://www.revistaau.com.br/arquitetura-urbanismo/170/fato-opniaocomo-resolver-o-transito-nas-grandes-cidades-87238-1.asp>. Acesso em: 1 abr. 2012.

DPOT. Conceito. Disponível em: <http://www.dpot.com.br/conceito.aspx>. Acesso em: 24 out. 2011.

FERNANDES, Pádua. A cidade bloqueada: a paralisação da política e Adoniran segundo Salmaso. $O$ palco e o mundo, 23 maio 2011. Disponível em: <http://opalcoeomundo.blogspot.com.br/ search/label/M\%C3\%B4nica\%20Salmaso>. Acesso em: 15 fev. 2012.

FERrAZ, Paulo. Paulo Ferraz: depoimento em áudio a Renata Roman para o programa Paisagens e poéticas. Transmissão: 7 dez. 2012 pela Mobile Radio na 30ª Bienal de São Paulo. Disponível em: <https://paisagensepoeticas.wordpress.com/2013/01/09/7_paulo-ferraz>. Acesso em: 14 jun. 2013.

FERreIRA, Flávio. Praça da Sé terá canteiros antibanho. Folha de S.Paulo, 10 jan. 2007. Caderno Cotidiano. Disponível em: <http://www1.folha.uol.com.br/fsp/cotidian/ff1001200717.htm>. Acesso em: 2 jun. 2012.

FERREIRA, João Sette Whitaker. São Paulo: cidade da intolerância, ou o urbanismo "à brasileira". Estudos Avançados, São Paulo, v. 25, n. 71, jan./abr. 2011.

FIORI ARANTES, Pedro; FIX, Mariana. Como o governo Lula pretende resolver o problema da habitação: alguns comentários sobre o pacote habitacional Minha Casa, Minha Vida. Correio da 
Cidadania, 1 ago. 2009. Disponível em: <http://www.correiocidadania.com.br/index.php?option= com_content $\&$ view=category $\& i d=66$ :pacote-habitacional $\& l$ layout=blog $\&$ Itemid=171>. Acesso em: 30 maio 2012

FIPE (Fundação Instituto de Pesquisas Econômicas); SÃo PAUlo (Cidade). Secretaria Municipal de Assistência e Desenvolvimento Social. Censo da População em Situação de Rua da Cidade de São Paulo 2009/2010. São Paulo, 2010.

GARCIA, Raphael Tsavkko. Lei Municipal n 6.681/65 ou como ser torturado em um ônibus. Blog do Tsavkko - The Angry Brazilian, 31 ago. 2009. Disponível em: <http://www.tsavkko.com.br/ 2009/08/lei-municipal-n668165-ou-como-ser.html>. Acesso em: 29 mar. 2012.

GARNIER, Jean-Pierre. Scénografie pour un simulacre: l'espace public réenchanté. Espaces et Societés, n. 143, p. 67-81, 2008.

Gregori, Lúcio. A iniquidade da tarifa. Piseagrama, n. 1, Ano 01, p. 46-8, jan. 2010.

Gullar, Ferreira. Os políticos do lixo. Folha de S.Paulo, 18 abr. 2010. Caderno Ilustrada. Disponível em: 〈http://www1.folha.uol.com.br/fsp/ilustrad/fq1804201022.htm〉. Acesso em: 21 out. 2011.

KeHL, Maria Rita. Cidade com desigualdade é um inferno. Brasil de Fato, 4 out. 2013. Entrevista concedida a Mariana Desidério. Disponível em: <http://www.brasildefato.com.br/node/26116>. Acesso em: 6 out. 2013.

Lecuyer, Alban; Rousseau, Max; Pate, Gilles. Entretien croisé entre Max Rousseau et Giles Paté. Tête-a-tête. Revue d'art et d'esthétique, n. 1 (Résister). Lormont: Le Bord de l'eau. Printemps 2011.

LORES, Raul Juste. Cultura do carro nos EUA da marcha a ré. Folha de S.Paulo, 22 jul. 2013. Caderno Mundo. Disponível em: <http://www1.folha.uol.com.br/fsp/mundo/120158-cultura-docarro-nos-eua-da-marcha-a-re.shtml>. Acesso em: 24 jul. 2013.

MARICATO, Ermínia. Metrópoles desgovernadas. Estudos Avançados, São Paulo, v. 25, n. 71, jan./abr. 2011.

Metrô. Pesquisa Origem e Destino. Região Metropolitana de São Paulo. Síntese das Informações da Pesquisa Domiciliar, dez. 2008. Disponível em: <http://www.metro.sp.gov.br/empresa/pesquisas/od_2007/teod.asp>. Acesso em: 16 fev. 2012.

Nobre, Eduardo A. C. Ampliação da Marginal do Tietê: demanda real ou rodoviarismo requentado? AU - Arquitetura e Urbanismo, v. 191, p. 58-63, 2010. Disponível em: $<$ http://www.revistaau.com.br/arquitetura-urbanismo/191/intersecao-ampliacao-da-marginal-tietedemanda-real-ou-rodoviarismo-161845-1.asp>. Acesso em: 16 fev. 2012.

RibeIRo JR., Amaury. "Homem-barata" habita esgoto de BH. Folha de S.Paulo, 16 jan. 1994. Caderno Brasil. Disponível em: <http://www1.folha.uol.com.br/fsp/1994/1/16/brasil/24.html>. Acesso em: 11 nov. 2011.

Rocha FILHO, Antônio. Cidade cria arquitetura antimendigo. Folha de S.Paulo, 4 set. 1994. Caderno Cotidiano. Disponível em: <http://www1.folha.uol.com.br/fsp/1994/9/04/cotidiano/2.html>. Acesso em: 24 out. 2011. 
ROLNIK, Raquel. Direito à moradia versus especulação imobiliária. Caros Amigos, ano XV, n. 169, abr. 2011. Entrevista concedida a Bárbara Mengardo e outros.

; KLintowitz, Danielle. (I)Mobilidade na cidade de São Paulo. Estudos Avançados, São Paulo, v. 25, n. 71, jan./abr. 2011.

SCHOR, Maria Sílvia; COSTA VIEIRA, Maria Antonieta da. Principais resultados do perfil socioeconômico da população de moradores de rua da área central da cidade de São Paulo, 2010. São Paulo, Faculdade de Economia, Administração e Contabilidade da Universidade de São Paulo. Disponível em: <http://www.prefeitura.sp.gov.br/cidade/secretarias/assistencia_social/observatorio_ social/pesquisas/index.php?p=18626>. Acesso em: 21 out. 2011.

SCHOR, Tatiana. O automóvel e o desgaste social. São Paulo em Perspectiva; v. 13, n. 3, p. 107-16, set. 1999.

Torres, Sérgio. Esgoto é moradia para dez pessoas. Folha de S.Paulo, 8 ago. 1997. Caderno Cotidiano. Disponível em: <http://www1.folha.uol.com.br/fsp/1997/8/08/cotidiano/28.html>. Acesso em: 11 nov. 2011.

TRANSPORTE desgovernado. Folha de S.Paulo, 31 mar. 2012. Editorial, p. A2. Disponível em: <http://www1.folha.uol.com.br/fsp/opiniao/34349-transporte-desgovernado.shtml>. Acesso em: 2 abr. 2012

VeIgA, Edison. A maldição do Fura-Fila. Veja São Paulo, 9 abr. 2008. Disponível em: <http://vejasaopaulo.abril.com.br/revista/vejasp/edicoes/2055/m0156311.html>. Acesso em: 2 ago. 2008.

ViannA, Túlio. Desmilitarizar e unificar a polícia. Revista Fórum, n. 115, out. 2012. Disponível em: <http://revistaforum.com.br/blog/2013/01/desmilitarizar-e-unificar-a-policia>. Acesso em: 30 set. 2013.

VIER, Suzana. Privilégio a automóveis vai levar SP a situação suicida. Brasil atual. Disponível em: $<$ http://www.redebrasilatual.com.br/temas/cidades/2011/09/privilegio-a-automoveis-vai-levar-sp-asituacao-suicida-alerta-especialista>. Acesso em: 16 fev. 2012.

VILlAÇA, Flávio. São Paulo: segregação urbana e desigualdade. Estudos Avançados, São Paulo, v. 25, n. 71, jan./abr. 2011.

WAINER, João. Casal mora em esgoto há quatro anos em SP. Folha de S.Paulo, 4 dez. 2005. Disponível em: <http://www1.folha.uol.com.br/fsp/dinheiro/fi0412200510.htm>. Acesso em: 11 nov. 2011.

Wisnik, Guilherme; Nobre, Ana Luiza; Nobre, Lígia. As cidades em processo. Folha de S.Paulo, 6 out. 2013. Caderno Ilustríssima, p. 6. Disponível em: <http://www1.folha.uol.com.br/ilustrissima/ 2013/10/1351801-as-cidades-em-processo.shtml>. Acesso em: 6 out. 2013.

Zanchetta, Diego; Bulgarelli. Prefeitura lista 1.053 imóveis sem uso. O Estado de S. Paulo, 24 set. 2011. Disponível em: <http://estadao.br.msn.com/ultimas-noticias/prefeitura-lista-1053-im\% C3\%B3veis-sem-uso-em-sp>. Acesso em: 30 set. 2011 


\section{Bibliografia geral}

ALCIDES, Sérgio. Por uma poética republicana. Jandira, Juiz de Fora, n. 2, 2005.

AlmeIdA, João Ferreira de. A Bíblia. Edição revista e atualizada no Brasil. São Paulo: Sociedade Bíblica do Brasil, 1993. Disponível em: <http://www.portaldabiblia.com/?do=p\&p=mat\%207:2427>. Acesso em: 3 set. 2011.

Andrade, Fabio de Souza. Poesia de olhos vazados. Folha de S.Paulo, 17 jan. 2009. Caderno Ilustrada. Disponível em: 〈http://www1.folha.uol.com.br/fsp/ilustrad/fq1701200916.htm〉. Acesso em: 2 jun. 2012.

ARriguCCI JR., Davi. Humildade, paixão e morte: a poesia de Manuel Bandeira. São Paulo: Companhia das Letras, 1992.

Azevedo, Carlito. Carlito Azevedo: depoimento concedido a Heitor Ferraz. Cult. Revista de Literatura Brasileira, São Paulo, n. 53, p. 5-9, dez. 2001.

BAILly, Jean-Cristophe. La ville à l'oeuvre. Paris: Jacques Bertoin, 1992.

BARros BAPTISTA, Abel. A angústia da insuficiência. Folha de S.Paulo, 12 set. 1999. Caderno Ilustrada. Disponível em: <http://www1.folha.uol.com.br/fsp/mais/fs12099917.htm>. Acesso em: 30 mar. 2010.

BENJAMIN, Walter. Sobre alguns temas em Baudelaire. In: Charles Baudelaire: um lírico no auge do capitalismo. São Paulo: Brasiliense, 1989. (Obras escolhidas, v. 3).

BERARDINELLI, Alfonso. Cidades visíveis na poesia moderna. In: Da poesia à prosa. São Paulo: Cosac Naify, 2007.

BERMAN, Marshall. Baudelaire: o modernismo das ruas. In: Tudo que é sólido desmancha no ar. São Paulo: Companhia das Letras, 1986.

Bosi, Ecléa. Memória e sociedade: lembranças de velhos. São Paulo: T. A. Queiroz, 1979.

Bosi, Viviana. Orelha para: FerRAZ, Paulo. De novo nada. São Paulo: Sebastião Grifo, 2007.

. Poesia auto-móvel. Teresa: Revista de Literatura Brasileira, n. 10-1, p. 121-41, 2010.

Calvino, Italo. Posfácio a: Collodi, Carlo. As aventuras de Pinóquio. 2. ed. Tradução de Ivo Barroso. São Paulo: Cosac Naify, 2012.

CAMPOS, Haroldo. Poesia e modernidade: da morte da arte à poesia pós-utópica. In: . $O$ arco-íris branco: ensaios de literatura. Rio de Janeiro: Imago, 1997.

CANDIDO, Antonio. O poeta itinerante. In: $O$ discurso e a cidade. São Paulo: Duas Cidades, 1993, p. 257-8.

CAScudo, Luís da Câmara. Dicionário do folclore brasileiro, v. 1. Rio de Janeiro: Instituto Nacional do Livro/Ministério da Educação, 1962.

Certeau, Michel de. Caminhadas pela cidade. In: A invenção do cotidiano: 1 . Artes de fazer. Petrópolis: Vozes, 1994, p. 169-91. 
Collodi, Carlo. As aventuras de Pinóquio. 2. ed. Tradução de Ivo Barroso. São Paulo: Cosac Naify, 2012.

Compagnon, Antoine. Le démon de la theorie: littérature et sens commun. Paris: Éditions du Seuil, 1998.

CORREIA, Marlene de Castro. O tópos BONDE na poesia de Mario de Andrade. In: Poesia de dois Andrades (e outros temas). Rio de Janeiro: Azougue, 2010, p. 207-4.

Costa PINTO, Manuel. Constatação do nada. Folha de S.Paulo, 17 nov. 2007. Caderno Ilustrada.

CURTIUS, Ernst Robert. Literatura europeia e Idade Média Latina. 3. ed. São Paulo: Edusp; Hucitec, 1996.

DANTAS, Vinícius. A nova poesia brasileira \& a poesia. Novos Estudos, São Paulo, n. 16, p. 40-53, dez. 1986.

DuRAND, Pascal. Poesia e cenário: o interior, o excesso, o nada. A propósito do "Lamento das puberdades difíceis”. Inimigo Rumor, Lisboa, São Paulo, Rio de Janeiro, 1. sem. 2004.

FERnANDES, Pádua. A rua em torno e a poesia sem centro: dois lançamentos de Paulo Ferraz. $K$ Jornal de Crítica, n. 13, p. 7, jul. 2007.

FerraZ, Paulo Rogério. Depois de tudo: fontes, aspectos e dois poetas, Régis Bonvicino e Carlito Azevedo. Departamento de Teoria Literária e Literatura Comparada, Faculdade de Filosofia Letras e Ciências Humanas, Universidade de São Paulo, 2004.

Flores, Wilson. Adoniran Barbosa e o progréssio de São Paulo. Texto Poético: revista do GT Teoria do Texto Poético/ANPOLL, v. 11, 2. sem 2011. Disponível em: <http://www. textopoetico.com.br/index.php?option=com_content\&view=article\&id=187\&Itemid=39>. Acesso em: 2 abr. 2012.

FOSTER, Hal. Contra o pluralismo. In: Recodificação: arte, espetáculo, política cultural. Tradução de Duda Machado. São Paulo: Casa Editorial Paulista, 1996.

O retorno do real. Revista Concinnitas, Rio de Janeiro, ano 6, v. 1, n. 8, jul. 2005. Corresponde ao capítulo 5 de The Return of The Real. Londres: MIT Press, 1996. Disponível em: <http://www.concinnitas.uerj.br/resumos8/foster.htm>. Acesso em: 28 mar. 2010.

FREUD, Sigmund (1930). O mal-estar na civilização. Rio de Janeiro: Imago, 1976. (Obras completas, v. XXI).

GullaR, Ferreira. Ferreira Gullar: depoimento ao programa Roda Vida. São Paulo: Rádio e Televisão Cultura, Fundação Padre Anchieta, 15 out. 2001. Transcrição disponível em: <http://www.rodaviva.fapesp.br/materia/243/entrevistados/ferreira_gullar_2001.htm>. Acesso em: 20 jun. 2013.

HANSEN, João Adolfo. A palavra-carcaça de Régis Bonvicino. In: Bonvicino, Régis. Página órfã. São Paulo: Martins, 2007, p. 111-27.

HORNE, Luz. Literaturas reales: transformaciones del realismo en la narrativa latinoamericana contemporânea. Rosario: Beatriz Viterbo, 2011. 
JACOBSON, Roman. Do realismo artístico (1921). In: TODOROv, Tzvetan. Teoria da literatura I. Lisboa: Edições 70, 1987.

KRACAUER, Siegfried. A viagem e a dança. In: O ornamento da massa. São Paulo: Cosac Naify, 2009, p. 81-9.

LAPlanche, Jean. Castração - Simbolizações. São Paulo: Martins Fontes, 1988.

LÍSIAS, Ricardo. Divórcio. Rio de Janeiro: Objetiva, 2013.

MARTINS, Alberto. A cidade e o passante: figuras de Evandro Carlos Jardim. In: MubARAC, Cláudio (Coord. Edit.). O desenho estampado e a obra gráfica de Evandro Carlos Jardim. São Paulo: Pinacoteca do Estado de São Paulo, 2005, p. 49-64.

- Conversa de porto. In: VÁRIOS AUTORES. Rodapé: crítica de literatura brasileira contemporânea, n. 3. São Paulo: Nankin, nov. 2004.

Literatura e transporte público. K Jornal de Crítica, n. 12, jun. 2007. Entrevista concedida a Eduardo Sterzi, Fabio Weintraub, Manuel da Costa Pinto e Reynaldo Damazio.

MAULPOIX, Jean-Michel. Dans la rue de la ville: réflexions sur le sort moderne de la poésie urbain. In: . Le poète perplexe. Paris: José Corti, 2002.

NAVES, Rodrigo. A forma difícil: ensaios sobre arte brasileira. 2. ed. São Paulo: Ática, 1997.

PaES, José Paulo. Samba, estereótipos, desforra. In: SchwaRZ, Roberto (Org.). Os pobres na literatura brasileira. São Paulo: Brasiliense, 1983.

PÉCORA, Alcir. O perigo da afetação inteligente. In: NeSTROVSKI, Arthur (Org.). Em branco e preto: artes brasileiras na Folha - 1990-2003. São Paulo: Publifolha, 2004.

. Orelha para: Bonvicino, Régis. Estado crítico. São Paulo: Hedra, 2013.

Pedrosa, Célia. Reapresentação da aurora (poesia e história em Carlos Drummond de Andrade). Disponível em: <http://www.pucrs.br/fale/pos/historiadaliteratura/gt/pedrosa.php>. Acesso em: 15 abr. 2010.

PennA, João Camillo. A violência da poesia. Alea: Estudos Neolatinos, v. 13, n. 2, p. 205-26, jul./dez. 2011. Disponível em: <http://www.scielo.br/pdf/alea/v13n2/02.pdf>. Acesso em: 30 set. 2013.

PILATI, Alexandre. Drummond participante: trabalho literário, reificação e nação. In: . A nação drummondiana: quatro estudos sobre a presença do Brasil na poesia de Carlos Drummond de Andrade. Rio de Janeiro: 7letras, 2009, p. 97-131.

PRADO JR., Bento. O boi e o marciano. In: Alguns ensaios. 2 ed. São Paulo: Paz e Terra, 2000.

RANCIERE, Jacques. Mallarmé: la politique de la sirène. Paris: Hachette Littératures, 1996.

RIDENTI, Marcelo. Brasilidade revolucionária: um século de cultura e política. São Paulo: Ed. Unesp, 2010. 
RosA, Victor da. Onde está sua ruptura? Sopro: Panfleto Político-Cultural, n. 94, ago. 2013. Disponível em: <http://www.culturaebarbarie.org/sopro/n94.html\#.Uj2zYdIjKPA>. Acesso em: 21 set. 2013.

SAnto Agostinho. De magistro. São Paulo: Abril Cultural, 1980. (Col. Os pensadores).

SARLO, Beatriz. Esquecer Benjamin. In: Paisagens imaginárias. São Paulo: Edusp, 2005, p. 104-5.

Schøllhammer, Karl Erik. Além ou aquém do realismo de choque. In: KrIEGER Olinto, Heidrun; Schøllhammer, Karl Erik (Orgs.). Literatura e realidade(s). Rio de Janeiro: 7letras, 2011.

- Realismo afetivo: evocar realismo além da representação. Estudos de Literatura Contemporânea, n. 39, p. 129-148, jan./jun. 2012. Disponível em: <http://www.gelbc.com.br/ pdf_revista/3907.pdf>. Acesso em: 14 set. 2013.

SCHWARZ, Roberto. O bonde, a carroça e o poeta modernista. In: Que horas são? São Paulo: Companhia das Letras, 1987, p. 11-28.

SENNETT, Richard. O declínio do homem público. In: . As tiranias da intimidade. São Paulo, Companhia das Letras, 1988.

SIMON, Iumna Maria. Apontamentos feitos por Fabio Weintraub do curso de pós-graduação "Preliminares ao estudo da experiência recente da poesia brasileira". Departamento de Teoria Literária e Literatura Comparada, Faculdade de Filosofia, Letra e Ciências Humanas, Universidade de São Paulo, segundo semestre de 2012.

. Condenados à tradição. Piauí, Rio de Janeiro, ano 6, n. 61, out. 2011, p. 83.

. Considerações sobre a poesia brasileira em fim de século. Novos Estudos, São Paulo, n. 55, p. 27-36, nov. 1999.

. Esteticismo e participação. Novos Estudos, São Paulo, n. 26, p. 120-40, mar. 1990.

. Linguagem poética e crescimento urbano-industrial. Revista de Letras, São Paulo, n. 20, p. 33-48, 1980.

. Situação de sítio. Novos Estudos, São Paulo, n. 82, p. 151-65, nov. 2008.

; Dantas, Vinicius. Consistência de Corola. Novos Estudos, São Paulo, n. 85, p. 215-35, nov. 2009.

; ___ Negativo e ornamental: um poema de Carlito Azevedo em seus problemas. Novos estudos, São Paulo, n. 91, p. 109-20, nov. 2011.

; ___ Poesia ruim, sociedade pior. Novos Estudos, São Paulo, n. 12, p. 48-61, jun. 1985.

STIGger, Veronica. Opisanie Świata. São Paulo: Cosac Naify, 2013.

SÜSSEKIND, Flora. Desterritorialização e forma literária: literatura brasileira contemporânea e experiência urbana. Literatura e Sociedade. São Paulo: Departamento de Teoria Literária e 
Literatura Comparada, Faculdade de Filosofia, Letras e Ciências Humanas, Universidade de São Paulo, n. 8, p. 60-81, 2005.

Objetos verbais não identificados. O Globo, 21 set. 2013. Caderno Prosa e Verso. Disponível em: <http://oglobo.globo.com/blogs/prosa/posts/2013/09/21/objetos-verbais-nao-identificadosum-ensaio-de-flora-sussekind-510390.asp>. Acesso em: 22 set. 2013.

VALENTIM, Fábio. Fotografia de um não lugar. In: BRACHER, Elisa. A cidade e suas margens. São Paulo: Ed. 34, 2008.

Weintraub, Fabio. Caos moralizado. K Jornal de Crítica, n. 12, jun. 2007.

Cerco de cinzas. Cult. Revista Brasileira de Literatura, São Paulo, n. 24, jul. 1999.

. Porto \& deriva. Sebastião, São Paulo, v. 2, 1 set. 2002.

. Tentação do zero. K Jornal de Crítica, n. 7, 2006.

WisniK, Guilherme. Em trânsito. In: MARTINS, Alberto (Coord. Edit.). Em trânsito: gravuras e esculturas de Alberto Martins - catálogo de exposição. São Paulo: Pinacoteca do Estado de São Paulo, 2007.

XAVIER, Ismail. O exemplar e o contingente no teatro das evidências. Literatura e Sociedade. São Paulo: Departamento de Teoria Literária e Literatura Comparada, Faculdade de Filosofia, Letras e Ciências Humanas, Universidade de São Paulo, n. 14, p. 15-23, 2010. 